Prepared in cooperation with the Brunswick/Glynn County Joint Water and Sewer Commission

\title{
Groundwater Flow in the Brunswick/Glynn County Area, Georgia, 2000-04
}

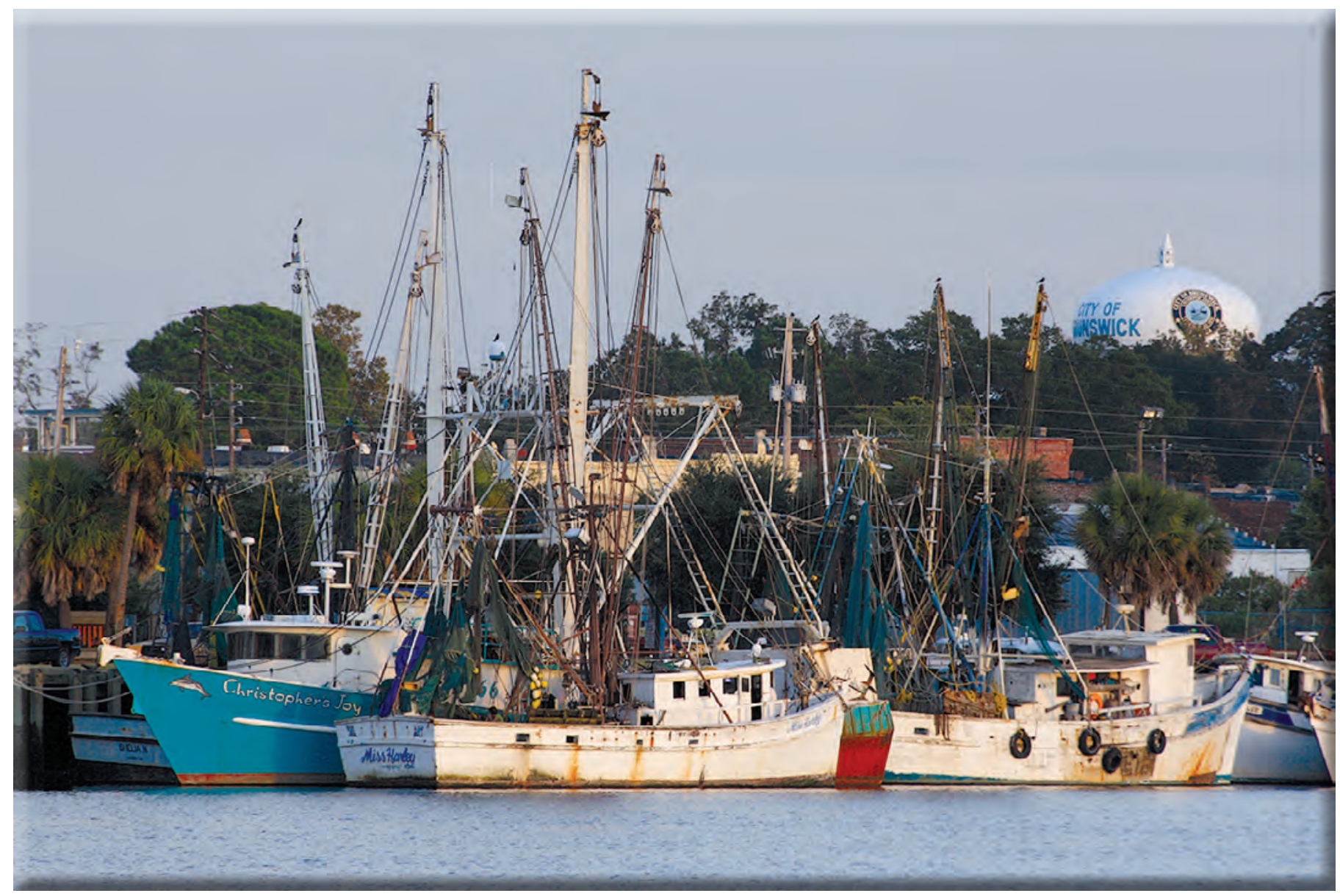

Scientific Investigations Report 2015-5061 
Cover. East River docks, Brunswick, Glynn County, Georgia (photograph by Alan M. Cressler, USGS). 


\section{Groundwater Flow in the Brunswick/Glynn County Area, Georgia, 2000-04}

By Gregory S. Cherry

Prepared in cooperation with the Brunswick/Glynn County Joint Water and Sewer Commission

Scientific Investigations Report 2015-5061 


\title{
U.S. Department of the Interior SALLY JEWELL, Secretary
}

\section{U.S. Geological Survey Suzette M. Kimball, Acting Director}

\author{
U.S. Geological Survey, Reston, Virginia: 2015
}

For more information on the USGS - the Federal source for science about the Earth, its natural and living resources, natural hazards, and the environment—visit http://www.usgs.gov or call 1-888-ASK-USGS.

For an overview of USGS information products, including maps, imagery, and publications, visit http://www.usgs.gov/pubprod/.

Any use of trade, firm, or product names is for descriptive purposes only and does not imply endorsement by the U.S. Government.

Although this information product, for the most part, is in the public domain, it also may contain copyrighted materials as noted in the text. Permission to reproduce copyrighted items must be secured from the copyright owner.

Suggested citation:

Cherry, G.S., 2015, Groundwater flow in the Brunswick/Glynn County area, Georgia, 2000-04: U.S. Geological Survey Scientific Investigations Report 2015-5061, 88 p., http://dx.doi.org/10.3133/sir20155061.

ISSN 2328-0328 (online) 


\section{Contents}

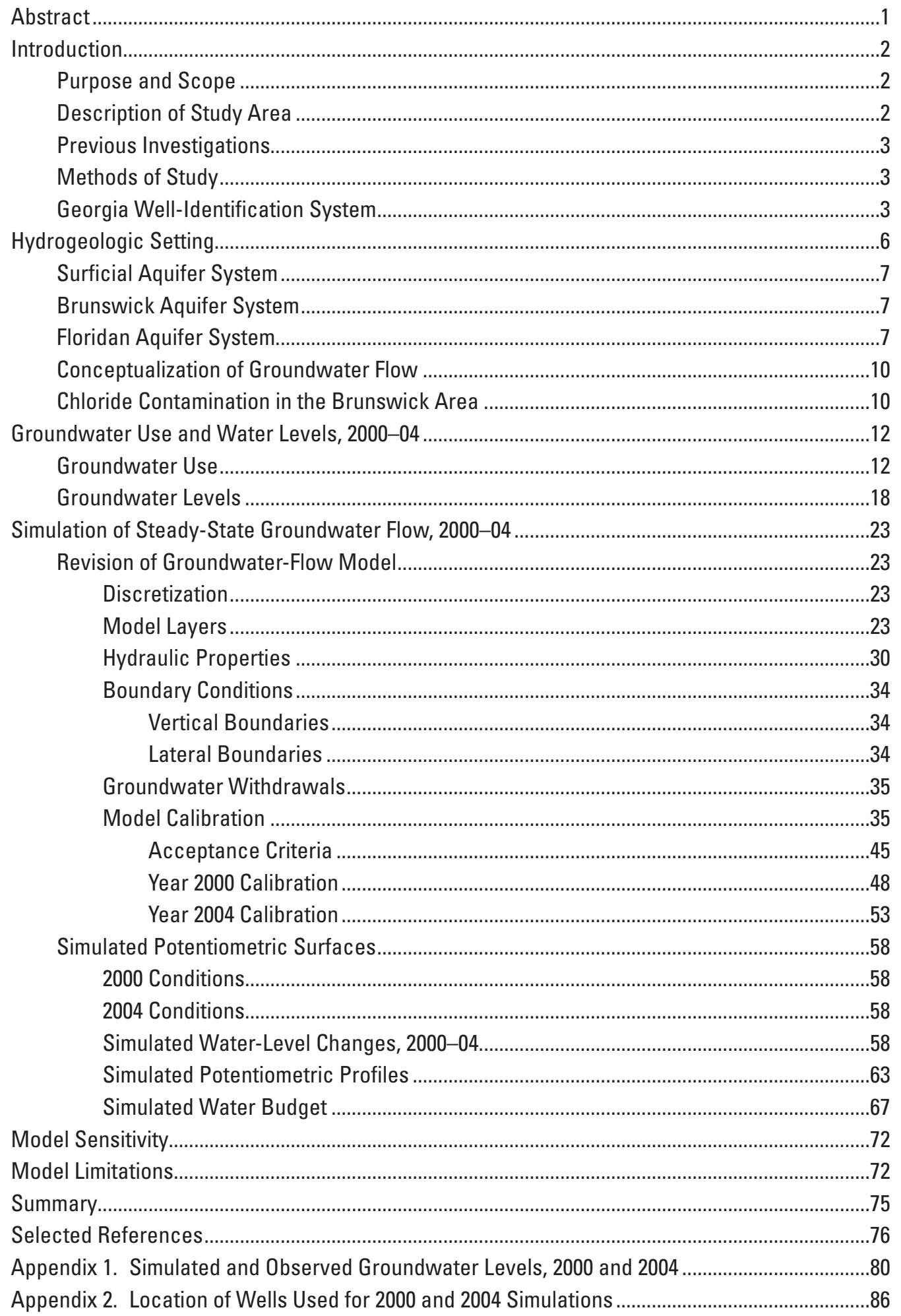




\section{Figures}

1. Maps showing location of 24-county coastal Georgia area, model area, major structural features, and 250-milligram-per-liter chloride concentration isochlor for June 2001 and 2005 near Brunswick, Georgia.

2. Generalized correlation chart of geologic and hydrogeologic units and model layers.

3. Schematic cross sections showing conceptual models of predevelopment (pre-1880s) and modern-day groundwater flow in the Floridan aquifer system from the outcrop area in the northwest to the offshore area in the southeast, coastal Georgia...

4. Map showing chloride concentrations in the Upper Floridan aquifer near the downtown Brunswick area, August 2007, and graphs showing chloride concentration in water for selected wells in the northern and southern Brunswick area, 1964-2007.

5. Graphs showing estimated groundwater pumpage from the Upper and Lower Floridan aquifers in the model area, and Upper Floridan aquifer in the Glynn County area, 1980-2004.

6. Graphs showing selected water-level hydrographs for the surficial aquifer, upper Brunswick aquifer, lower Brunswick aquifer, Upper Floridan aquifer upper water-bearing zone, Upper Floridan aquifer lower water-bearing zone, Lower Floridan aquifer, and Lower Floridan aquifer Fernandina permeable zone, in the Brunswick/Glynn County, Georgia area, 2000-04.

7. Maps showing revised model grid, major production wells, observation wells used during June of 2004, and outline of the 2004 chloride plume for the Upper Floridan aquifer in the Brunswick area..

8. Schematic diagram showing model layers and boundary conditions

9. Hydrogeologic sections showing vertical discretization of hydrogeologic units simulated by the revised model.

10. Maps showing hydraulic property zones for the regional model near Brunswick/Glynn County, Georgia . .31

11. Maps showing distribution of groundwater pumpage for 2000 for model layer 3 , upper Brunswick aquifer; model layer 5, lower Brunswick aquifer; model layer 7, Upper Floridan aquifer upper water-bearing zone; model layer 9, Upper Floridan aquifer lower water-bearing zone; and model layer 11, Lower Floridan aquifer

12. Maps showing distribution of groundwater pumpage for $\mathbf{2 0 0 4}$ for model layer 3 , upper Brunswick aquifer; model layer 5, lower Brunswick aquifer; model layer 7, Upper Floridan aquifer upper water-bearing zone; model layer 9, Upper Floridan aquifer lower water-bearing zone; and model layer 11, Lower Floridan aquifer

13. Boxplots showing difference (residuals) between simulated and observed heads for 2000 simulation in the regional model area and Brunswick/Glynn County area........48

14. Maps showing simulated 2000 potentiometric surfaces and water-level residuals by model layer: layer 3, upper Brunswick aquifer, model area; layer 5, lower Brunswick aquifer, model area; layer 7, upper water-bearing zone of the Upper Floridan aquifer, model area; layer 9 , lower water-bearing zone of the Upper Floridan aquifer; layer 7, upper water-bearing zone of the Upper Floridan aquifer, Glynn County and Brunswick area enlargement; layer 9 , lower water-bearing zone of the Upper Floridan aquifer; and layer 11, Lower Floridan aquifer, model area and Glynn County enlargement. 
15. Boxplots showing difference (residuals) between simulated and observed heads for 2004 simulation in the regional model area, and Brunswick/Glynn County area.......53

16. Maps showing simulated 2004 potentiometric surfaces and water-level residuals by model layer: layer 3, upper Brunswick aquifer, model area; layer 5, lower Brunswick aquifer, model area; layer 7, upper water-bearing zone of the Upper Floridan aquifer, model area; layer 9, lower water-bearing zone of the Upper Floridan aquifer; layer 7, upper water-bearing zone of the Upper Floridan aquifer, Glynn County and Brunswick area enlargement; layer 9, lower water-bearing zone of the Upper Floridan aquifer; and layer 11, Lower Floridan aquifer, model area and Glynn County enlargement.

17. Hydrographs showing selected water-levels and simulated heads for upper Brunswick aquifer, Upper Floridan aquifer upper water-bearing zone, Upper Floridan aquifer lower water-bearing zone, Lower Floridan aquifer, and Lower Floridan aquifer Fernandina permeable zone, Glynn County, Georgia, 2000-2004

18. Maps showing simulated water-level change from 2000 to 2004 for, model layer 3 , upper Brunswick aquifer, model layer 5, lower Brunswick aquifer, upper waterbearing zone of Upper Floridan aquifer, lower water-bearing zone of Upper Floridan aquifer, and Lower Floridan aquifer......

19. Graphs showing simulated and observed potentiometric profiles near chloride plume during 2000

20. Graphs showing simulated and observed potentiometric profiles near chloride plume during 2004

21. Schematic diagram showing simulated water budget for regional model during 2000 and 2004, and water budgets in Glynn County during 2000 and 2004.

22. Graph showing composite-scaled sensitivity of selected model parameters .................73

2-1. Maps showing location of wells used for 2000 and 2004 simulations in study area; McIntosh, Glynn, and Camden Counties; and Brunswick.

\section{Tables}

1. Estimated groundwater pumpage from the Upper and Lower Floridan aquifers in the coastal area of Georgia and adjacent parts of South Carolina and Florida, $1980-2004$

2. Water-level measurements taken during 2000 and 2004 and observed water-level change during the same period

3. Water-level measurements taken during 2000 and 2004 and observed water-level change during the same period in the Brunswick/Glynn County area.

4. Horizontal and vertical hydraulic conductivity values assigned to hydraulic property zones for the original and revised groundwater-flow models ..........................28

5. Calibration statistics for simulated heads for 2000 conditions .........................................46

6. Calibration statistics for simulated heads for 2004 conditions .........................................47

7. Simulated and observed groundwater levels for 2000 , and residuals in wells used to construct profiles in the Brunswick area.

8. Simulated and observed groundwater levels for 2004, and residuals in wells used to construct profiles in the Brunswick area..

9. Flow-budget components for 2000 and 2004 for entire model area .................................68

10. Flow-budget components for 2000 and 2004 in the Brunswick/Glynn County area ........69

1-1. Simulated and observed groundwater levels, 2000 and 2004 


\section{Conversion Factors}

Inch/Pound to SI

\begin{tabular}{|c|c|c|}
\hline Multiply & By & To obtain \\
\hline \multicolumn{3}{|c|}{ Length } \\
\hline inch & 2.54 & centimeter $(\mathrm{cm})$ \\
\hline foot $(\mathrm{ft})$ & 0.3048 & meter $(\mathrm{m})$ \\
\hline mile (mi) & 1.609 & kilometer (km) \\
\hline \multicolumn{3}{|c|}{ Area } \\
\hline square mile $\left(\mathrm{mi}^{2}\right)$ & 59.0 & hectare (ha) \\
\hline square mile $\left(\mathrm{mi}^{2}\right)$ & 2.590 & square kilometer $\left(\mathrm{km}^{2}\right)$ \\
\hline \multicolumn{3}{|c|}{ Volume } \\
\hline million gallons (Mgal) & & cubic meter $\left(\mathrm{m}^{3}\right)$ \\
\hline \multicolumn{3}{|c|}{ Flow rate } \\
\hline inch per year & 25.4 & millimeter per year \\
\hline foot per day (ft/d) & 0.3048 & meter per day $(\mathrm{m} / \mathrm{d})$ \\
\hline million gallons per day (Mgal/d) & 0.04381 & cubic meter per second $\left(\mathrm{m}^{3} / \mathrm{s}\right)$ \\
\hline \multicolumn{3}{|c|}{ Hydraulic conductivity } \\
\hline foot per day (ft/d) & 0.3048 & meter per day $(\mathrm{m} / \mathrm{d})$ \\
\hline \multicolumn{3}{|c|}{ Transmissivity* $^{*}$} \\
\hline foot squared per day $\left(\mathrm{ft}^{2} / \mathrm{d}\right)$ & 0.0929 & meter squared per day $\left(\mathrm{m}^{2} / \mathrm{d}\right)$ \\
\hline \multicolumn{3}{|c|}{ Potentiometric gradient } \\
\hline foot per mile (ft/mi) & 0.1894 & meter per kilometer $(\mathrm{m} / \mathrm{km})$ \\
\hline
\end{tabular}

Temperature in degrees Fahrenheit $\left({ }^{\circ} \mathrm{F}\right)$ may be converted to degrees Celsius $\left({ }^{\circ} \mathrm{C}\right)$ as follows:

${ }^{\circ} \mathrm{C}=\left({ }^{\circ} \mathrm{F}-32\right) / 1.8$ 


\section{Supplemental Information}

*Transmissivity: The standard unit for transmissivity is cubic foot per day per square foot times foot of aquifer thickness $\left[\left(\mathrm{ft}^{3} / \mathrm{d}\right) / \mathrm{ft}^{2}\right] \mathrm{ft}$. In this report, the mathematically reduced form, foot squared per day $\left(\mathrm{ft}^{2} / \mathrm{d}\right)$, is used for convenience.

Specific conductance is given in microsiemens per centimeter at 25 degrees Celsius $(\mu \mathrm{S} / \mathrm{cm}$ at $\left.25^{\circ} \mathrm{C}\right)$.

Concentrations of chemical constituents in water are given either in milligrams per liter ( $\mathrm{mg} / \mathrm{L})$ or micrograms per liter $(\mu \mathrm{g} / \mathrm{L})$.

\section{Datums}

Vertical coordinate information is referenced to the North American Vertical Datum of 1988 (NAVD 88).

Horizontal coordinate information is referenced to North American Datum of 1983 (NAD 83).

Altitude, as used in this report, refers to distance above the vertical datum.

\section{Abbreviations}

$\begin{array}{ll}\text { GaEPD } & \text { Georgia Environmental Protection Division } \\ \text { JWSC } & \text { Joint Water and Sewer Commission } \\ \text { LFA } & \text { Lower Floridan aquifer } \\ \text { LWBZ } & \text { lower water-bearing zone } \\ \text { NWIS } & \text { National Water Information System } \\ \text { RMSE } & \text { root mean square error } \\ \text { SCDHEC } & \text { South Carolina Department of Health and Environmental Control } \\ \text { UFA } & \text { Upper Floridan aquifer } \\ \text { USGS } & \text { U.S. Geological Survey } \\ \text { UWBZ } & \text { upper water-bearing zone } \\ \text { WRMAC } & \text { Water Resources Management Advisory Committee }\end{array}$




\section{Acknowledgments}

The author extends thanks to Keith Morgan and Billy Simmons of the Brunswick/Glynn County Joint Water and Sewer Commission and to James Kennedy, State Geologist, Georgia Environmental Protection Division (GaEPD), for support of ongoing water-resources investigations in the Brunswick/Glynn County area. During early stages of model development, members of the Brunswick/Glynn County Water Resources Management Advisory Committee (WRMAC) provided technical guidance, including development of water-management scenarios for evaluation by the revised model. WRMAC members were, Bobby Palmer, Chair, private citizen; Glenn Hoffman, Vice Chair, Hercules-Pinova Inc.; Dan McFee, City of Brunswick; Keith Morgan, Brunswick/Glynn County Joint Sewer and Water Commission; John Day, Jekyll Island Authority; Kenneth Hase, GP-Cellulose; Jim Benson, private citizen; William Francis, private citizen; Dick Johnston, private citizen; Hal Hart, private citizen; David Kyler, private citizen; and Milton Peterman, private citizen.

Special thanks are extended to Dorothy Payne of the USGS for her assistance with preliminary simulations and compilation of pumping data for 2004. Thanks are also extended to Alan Cressler and Welby Stayton, USGS, who collected water-level data during the June 2004 synoptic survey, and to Jaime Painter, USGS, who provided assistance in the development of model input and display of model results using geographic information system techniques.

Elliott Jones and Michael Peck, USGS, provided valuable unpublished data in the Brunswick/ Glynn County area and access to the archive of acoustic televiewer images taken from TW-26 on Colonels Island and other test holes in the Brunswick area. 


\title{
Groundwater Flow in the Brunswick/Glynn County Area, Georgia, 2000-04
}

\author{
By Gregory S. Cherry
}

\section{Abstract}

An existing regional steady-state model for coastal Georgia, and parts of South Carolina and Florida, was revised to evaluate the local effects of pumping on the migration of high chloride (saline) water in the Upper Floridan aquifer located in the Brunswick/Glynn County, Georgia (Ga.) area. Revisions were focused on enhancing the horizontal and vertical resolution of the regional model grid in the vicinity of saline water. Modifications to the regional model consisted of (1) limiting grid size to a maximum of 500 feet (ft) per side in the vicinity of chloride contamination; (2) representing the upper and lower Brunswick aquifers with distinct model layers; (3) similarly, representing upper and lower waterbearing zones of the Upper Floridan aquifer with distinct model layers in Glynn and Camden Counties, Ga.; and (4) establishing new hydraulic-property zones in the Upper Floridan aquifer. The revised model simulated steady-state conditions that were assumed to exist during 2000 and 2004.

Calibration of the revised steady-state model using pumping rates from 2000 indicates a "good" match $( \pm 10 \mathrm{ft})$ based on 181 observations, with median residuals (simulated minus observed water levels) in each of the active model layers ranging from -8.62 to $4.67 \mathrm{ft}$, and root mean square error (RMSE) ranging from 10.9 to $11.4 \mathrm{ft}$. In the Brunswick/ Glynn County area, groundwater-level residuals in the upper water-bearing zone of the Upper Floridan aquifer (layer 7) indicate an "excellent" match $( \pm 5 \mathrm{ft})$ based on 41 observations with a median residual of $-0.35 \mathrm{ft}$ and RMSE of $4.32 \mathrm{ft}$.

Calibration of the revised steady-state model using 2004 pumping rates and adjusted specified-head input values in the Floridan aquifer system indicates a "good" match $( \pm 10 \mathrm{ft})$ based on 88 observations, with median residuals in each of the active model layers ranging from -6.31 to $-2.05 \mathrm{ft}$, and RMSE ranging from -6.95 to $14.5 \mathrm{ft}$. In the Brunswick/Glynn County area, groundwater-level residuals in the upper waterbearing zone of the Upper Floridan aquifer (layer 7) indicate an "excellent" match $( \pm 5 \mathrm{ft})$ based on 32 observations with a median residual of $-1.50 \mathrm{ft}$ and RMSE of $5.34 \mathrm{ft}$.

Simulated potentiometric surfaces for 2000 and 2004 indicate coastward groundwater flow in the Upper and Lower Floridan aquifers influenced by pumping centers at Savannah,
Jesup, and Brunswick, Ga., and indicate steep potentiometric gradients to the west and north of the Gulf Trough. In the Brunswick/Glynn County area, simulated industrial production wells located north of downtown Brunswick intercept local groundwater flow in the upper and lower water-bearing zones of the Upper Floridan aquifer and have created a cone of depression that locally alters the regional coastward flow direction.

Maps of simulated water-level change during the 2000-04 period show differences in groundwater levels in the Upper Floridan aquifer that range from $-2.5 \mathrm{ft}$ to more than $5 \mathrm{ft}$ in areas of coastal Georgia, and more than $20 \mathrm{ft}$ near the Georgia-Florida State Line. Positive values indicate higher simulated water levels during 2004 than during 2000, which were caused by reduced pumping in the Upper Floridan aquifer prompted by the shutdown of a paper mill near the southern model boundary in 2002 and increased recharge following a prolonged drought during 1998-2002.

Simulated potentiometric profiles for 2000 and 2004 were used to evaluate the potentiometric gradients in the upper water-bearing zone of the Upper Floridan aquifer (layer 7) near the chloride plume in the downtown Brunswick area. Four potentiometric profiles were constructed for 2000 to compare the simulated and observed water levels in 13 wells and were oriented outward from a primary well field. The simulated potentiometric gradients from the four profiles for 2000 ranged from 3.6 to 5.2 feet per mile (ft/mi) compared to observed values ranging from 4.1 to $5.6 \mathrm{ft} / \mathrm{mi}$. The five potentiometric profiles constructed for 2004 allowed for a similar comparison using simulated and observed water levels in 18 wells. The simulated potentiometric gradients from the five profiles for 2000 ranged from 3.6 to $11.1 \mathrm{ft} / \mathrm{mi}$ compared to observed values ranging from 3.8 to $10.2 \mathrm{ft} / \mathrm{mi}$. Simulated potentiometric gradients were higher for 2004 than for 2000 because of the inclusion of a well located within the cone of depression near downtown Brunswick.

Composite-scaled sensitivities of the model parameters indicate the revised model is most sensitive to pumping rates, followed by the horizontal hydraulic conductivity in the Upper Floridan aquifer for zones along coastal Georgia. The revised model is least sensitive to the horizontal hydraulic conductivity of the confining units and vertical hydraulic conductivity of the aquifers. For parameters defined by hydraulic-property 
zones in the upper and lower water-bearing zones of the Upper Floridan aquifer, such as horizontal hydraulic conductivity, model sensitivity was not as great in the Brunswick/Glynn County area as other areas along coastal Georgia. The model exhibited more sensitivity to these parameters however, than to parameters representing the majority of zones defining the vertical hydraulic conductivity of the confining units, which originally were assumed to govern upward migration of chloride contamination into this aquifer.

Analysis of simulated water-budget components for 2000 and 2004 indicate that specified-head boundaries in the Floridan aquifer system to the south and southwest of the regional model area control about 70 percent of inflows and nearly 50 percent of outflows to the model region. Other water budget components indicate an 80-million-gallon-per-day decrease in pumping from the Floridan aquifer system during this period.

\section{Introduction}

In the Brunswick/Glynn County, Georgia (Ga.) area, saltwater intrusion has been contaminating the Upper Floridan aquifer (UFA) for more than 50 years. Presently (2014), within an area covering several square miles of downtown Brunswick, the aquifer yields water that has a chloride concentration greater than 2,000 milligrams per liter $(\mathrm{mg} / \mathrm{L})$, well above the 250-mg/L State and Federal secondary drinking-water standard (Georgia Environmental Protection Division, 1997; U.S. Environmental Protection Agency, 2000). Saltwater contamination has constrained further development of the UFA in the Brunswick area, prompting interest in the development of alternative sources of water supply, primarily from the shallower surficial and Brunswick aquifer systems. Further development of the UFA is limited to areas outside of the chloride plume and will be performed in a way that will minimize migration of groundwater with high-chloride concentrations and maintain hydraulic-head gradients toward active pumping centers in the area. The U.S. Geological Survey (USGS), in cooperation with the Brunswick/Glynn County Joint Water and Sewer Commission (JWSC) and the Georgia Environmental Protection Division (GaEPD), revised an existing groundwater model to investigate the effects of pumping on the migration of high-chloride water in the Brunswick/Glynn County area, thereby providing scientific information essential for managing water resources along the Georgia coast.

In this investigation, the horizontal and vertical resolutions of an existing regional groundwater-flow model (Payne and others, 2005) were increased to more accurately simulate the effects of pumping in the vicinity of the chloride plume near downtown Brunswick. The existing regional model, hereafter referred to as the original model, was modified by (1) reducing grid dimensions to a maximum of 500 feet $(\mathrm{ft})$ per side in the vicinity of the chloride plume; (2) subdividing the Brunswick aquifer system into the upper and lower Brunswick aquifers; (3) subdividing the UFA into the upper and lower water-bearing zones (UWBZ and LWBZ, respectively) in Glynn and Camden
Counties; and (4) establishing new hydraulic property zones in the UFA to improve model calibration in the Brunswick/ Glynn County area. The revised model is intended to establish a framework for the Brunswick/Glynn County area that will allow future investigations to evaluate the long-term effects of selected pumping scenarios on groundwater levels and flow paths near areas of chloride contamination.

\section{Purpose and Scope}

The purpose of this report is to document the simulation of groundwater flow in the Brunswick/Glynn County area of Georgia during 2000-04. The report describes revisions to a previously published application of the USGS modular finitedifference computer program (MODFLOW-2000; Harbaugh and others, 2000) developed by Payne and others (2005) to simulate regional groundwater flow along the Georgia coast in the Brunswick and Floridan aquifer systems during 2000-04. These revisions to the original model include (1) increased spatial resolution near the downtown Brunswick, Ga., area, (2) additional hydraulic-property zones in the UFA near Brunswick/Glynn County area, and (3) subdivision of the Brunswick aquifer system and Floridan aquifer system into separate model layers to represent the local hydrogeology.

The purpose of the revised model is to simulate the longterm steady-state effect of changing mean-annual pumping during 2000 and 2004 on groundwater levels and evaluate changes in hydraulic gradients near pumping centers in the Brunswick area. Local hydraulic gradients control the direction and rate of chloride migration in the Floridan aquifer system. Steady-state simulation was considered appropriate given the regional groundwater-flow characteristics of the Floridan aquifer system and the years 2000 and 2004 were chosen because of available groundwater-level (see appendix 1) and pumpage data.

To fully document the model revision process, this report describes (1) revisions to the original model, (2) the boundary conditions used, (3) the approach used to calibrate the revised model, (4) water budget calculations, and (5) the sensitivity analysis. Additional maps and tables of groundwater levels and residuals (simulated minus observed groundwater levels) are included in support of the calibration process, along with a section that describes limitations of the model analysis.

\section{Description of Study Area}

Glynn County is located in the Coastal Plain physiographic province on Georgia's Atlantic Coast about 80 miles (mi) south of Savannah, Ga., and about $87 \mathrm{mi}$ north of Jacksonville, Florida (Fla.; fig. 1). Glynn County encompasses about 422 square miles $\left(\mathrm{mi}^{2}\right)$ and is bordered on the north by the Altamaha River, which empties into the Atlantic Ocean north of St. Simons Island. Altitudes in Glynn County range from $0 \mathrm{ft}$ along the coast to $40 \mathrm{ft}$ in the northwestern part of the county.

The City of Brunswick is located on a peninsula in Glynn County and encompasses about $50 \mathrm{mi}^{2}$. The city is bordered by 
St. Simons and Jekyll Islands to the east and by the Brunswick and Little Satilla Rivers to the west and south, respectively (fig. 1). Both rivers form tidally influenced estuaries in the Brunswick area.

The population of Glynn County was 79,626 in 2010 (U.S. Census Bureau, 2010). The primary population center of Glynn County is the City of Brunswick, and a secondary population center has developed into an urbanized area on the southern part of St. Simons Island. Outside the urbanized areas near the City of Brunswick and St. Simons Island, land use in Glynn County is a mixture of forest, grazed woodland, marsh, and swampland.

Glynn County has a climate classified as warm temperate and fully humid, with warm summers (Kottek and others, 2006). The average temperature for the climate-normal period of 1981-2010 was 68.1 degrees Fahrenheit, based on data compiled at St. Simons Island, Ga. (National Oceanic and Atmospheric Administration, 2014). Mean-annual precipitation for the same period is 45.0 inches, with the heaviest rainfall occurring during the months of June, August, and September. Glynn County is located in the central subarea of the 24-county coastal area designated by the GaEPD, which subdivided the area into northern, southern, and central subareas to facilitate water management practices (fig. 1).

\section{Previous Investigations}

Because this study uses a revised version of a previously developed model (Payne and others, 2005) to evaluate groundwater flow in the Brunswick/Glynn County area, the reader is referred to the original report for a complete list of the literature pertaining to hydrogeologic investigations for the regional model area. The publications listed here pertain to the Brunswick/Glynn County area.

Warren (1944) discussed the occurrence of brackish water in a city well at Brunswick and the possibility of saltwater encroachment in Glynn County. Wait $(1962,1965)$, Wait and Gregg (1973), and Gregg and Zimmerman (1974) documented the chloride contamination problem near downtown Brunswick, which included water-level and waterchemistry data. Krause and others (1984) identified wells in the Glynn County area that could be used to monitor chloride concentration and proposed sites for installation of additional monitor wells in the coastal area. Randolph and Krause (1990) developed a subregional groundwater model of Glynn County and the surrounding area that was linked to a regional model developed earlier (Krause and Randolph, 1989). Maslia and Prowell (1990) inferred major northeast-southwest-trending faults through the downtown Brunswick area based on structural analysis of geophysical data, northeastward elongation of the potentiometric surface of the UFA, and breaches in the local confining unit that influence the area of chloride contamination. As part of a regional evaluation of geology and groundwater resources, Clarke and others (1990) described water-bearing units in Miocene sediments in the Glynn County area. Jones and Maslia (1994) presented selected groundwaterlevel and water-quality data, and aquifer properties of the UFA for the Brunswick area. Clarke and Krause (2000) updated the subregional Brunswick/Glynn County model (Randolph and Krause, 1990) based on a comparison to other models developed in the area, and used the revised model to simulate a variety of water-management scenarios in the coastal area of Georgia. Jones and others (2002) presented evidence from 2,727-foot-deep test well 33H188 (TW-26) on Colonels Island, indicating localized faulting and dissolution within the Floridan aquifer system. Cherry (2007), Cherry and Clarke (2008), and Cherry and others (2010 and 2011) described changes in the chloride plume in the Brunswick area based on annual chloride sampling.

\section{Methods of Study}

This study updates and refines an existing regional groundwater-flow model of coastal Georgia and adjacent parts of South Carolina and Florida (Payne and others, 2005) to enable locally detailed simulation of groundwater flow in areas exceeding the $250-\mathrm{mg} / \mathrm{L}$ State and Federal secondary drinkingwater standard for chloride near downtown Brunswick, Ga. (Georgia Environmental Protection Division, 1997; U.S. Environmental Protection Agency, 2000).

Information about groundwater withdrawals during 2000-04 was compiled from the records of South Carolina Department of Health and Environmental Control (SCDHEC), $\mathrm{GaEPD}$, and USGS, which were developed into model input. The existing model grid was refined to enhance resolution of simulated groundwater levels in the Brunswick/Glynn County area. Two active model layers were added, based on the local hydrogeology, to represent additional water-bearing units within the Brunswick aquifer system and UFA. Waterlevel data for 2004 were compiled for 88 wells distributed throughout coastal Georgia. These data, together with data collected from 181 wells during 2000 (Payne and others, 2005), were used to calculate water-level residuals representing simulated minus observed water levels.

\section{Georgia Well-Identification System}

Wells described in this report are assigned a well identifier according to a system based on the index of U.S. Geological Survey (USGS) 7.5-minute topographic maps of Georgia. Each map in Georgia has been assigned a two- to three-digit number and letter designation (for example, $07 \mathrm{H}$ ) beginning at the southwestern corner of the State. Numbers increase sequentially eastward and letters advance alphabetically northward. Quadrangles in the northern part of the State are designated by double letters: AA follows Z, and so forth. The letters "I," "O," "II," and "OO" are not used. Wells inventoried in each quadrangle are numbered consecutively, beginning with 001. Thus, the fourth well inventoried in the $34 \mathrm{H}$ quadrangle is designated 34H004. In the USGS National Water Information System (NWIS) database, this information is stored in the "Station Name" field; in NWIS Web, it is labeled "Site Name." 


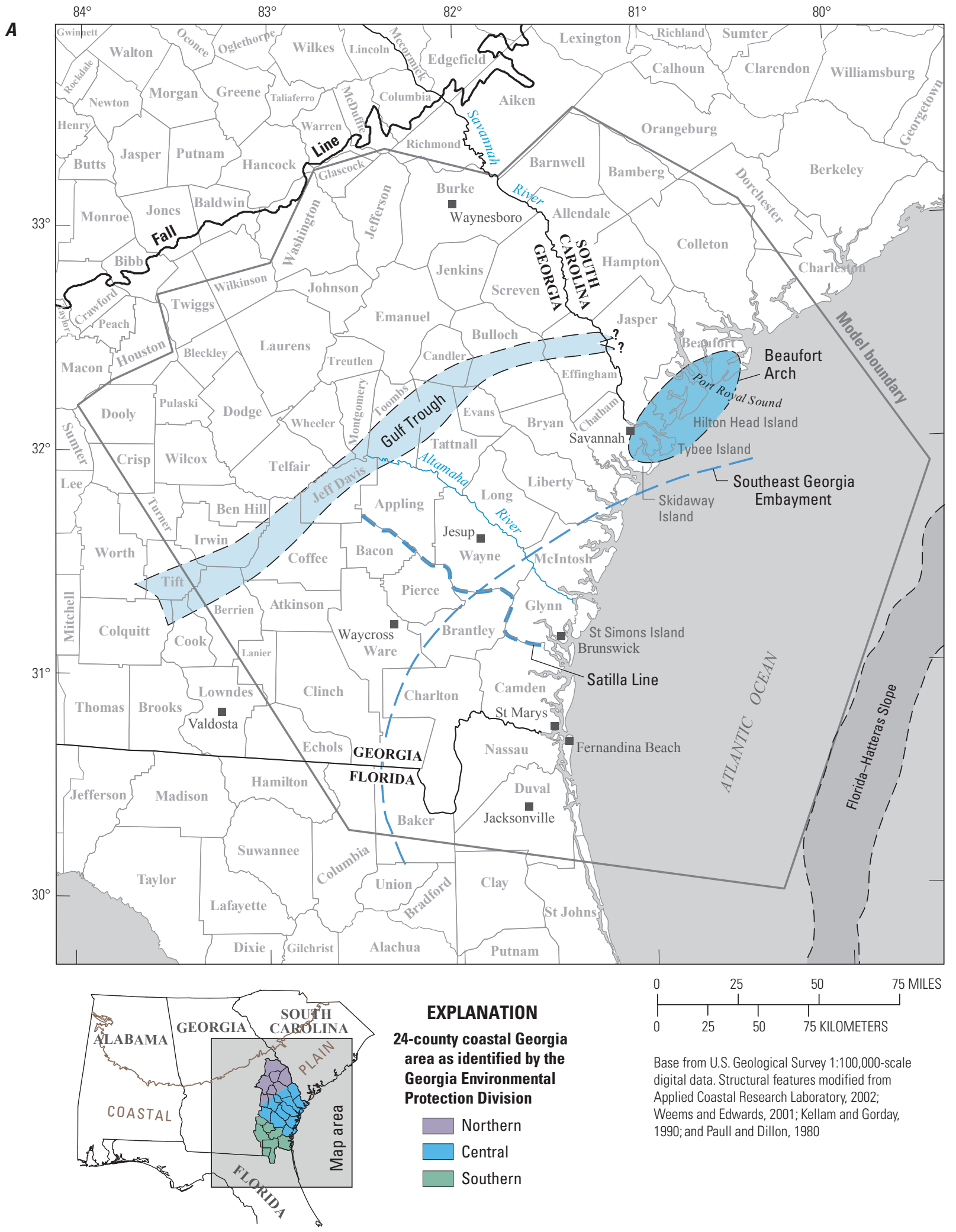

Figure 1. A, Location of 24-county coastal Georgia area, model area, major structural features, and B, 250-milligramper-liter (mg/L) chloride concentration isochlor for June 2001 and 2005 near Brunswick, Georgia (modified from Payne and others, 2005; Leeth and others, 2003 and 2007). 


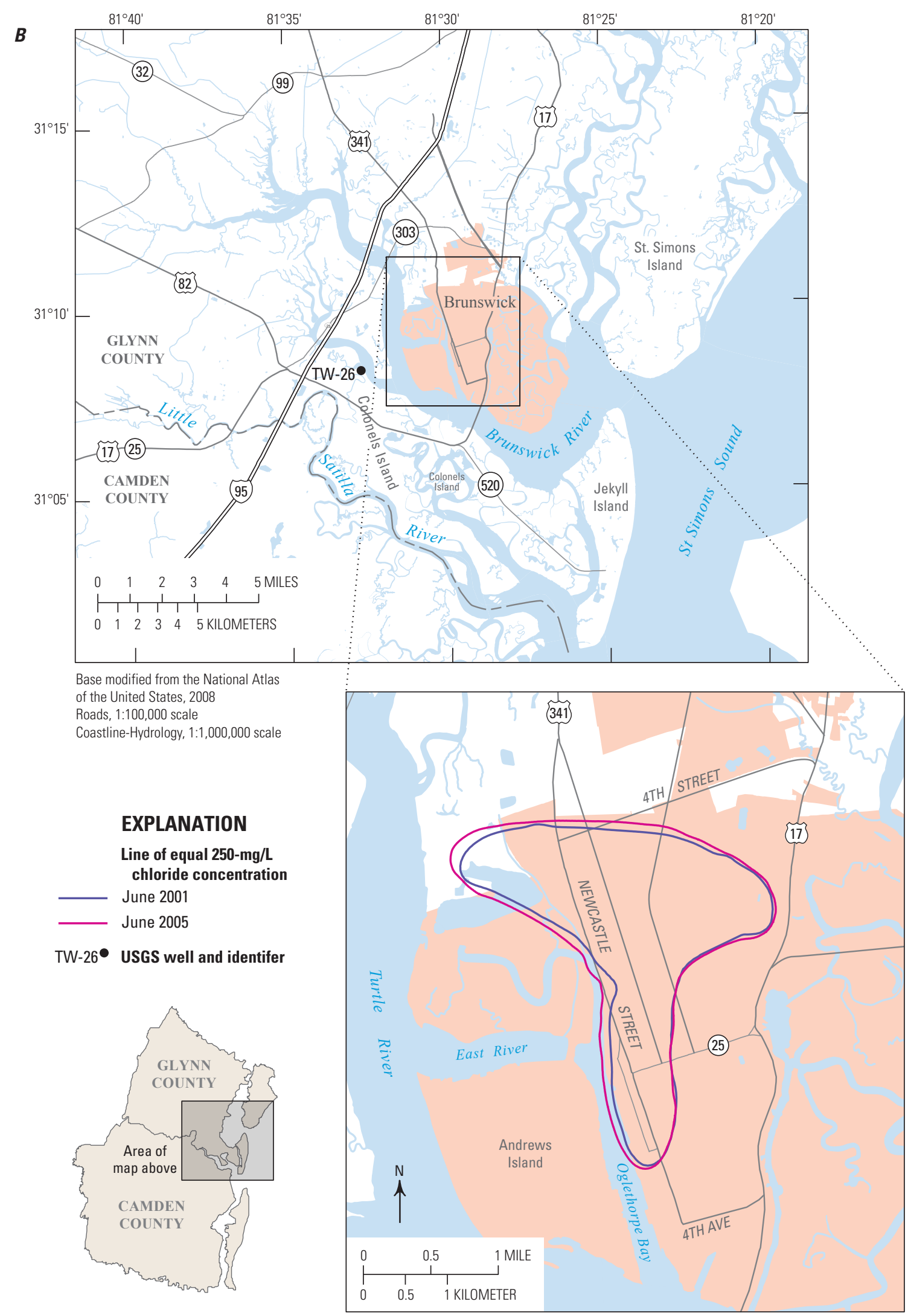

Figure 1. A, Location of 24-county coastal Georgia area, model area, major structural features, and $B$, 250-milligramper-liter (mg/L) chloride concentration isochlor for June 2001 and 2005 near Brunswick, Georgia (modified from Payne and others, 2005; Leeth and others, 2003 and 2007).-Continued 


\section{Hydrogeologic Setting}

Coastal Plain sediments consist of consolidated to unconsolidated layers of sand and clay, to semiconsolidated to dense layers of limestone and dolomite, which range in age from Late Cretaceous to Holocene (fig. 2). In general, these hydrogeologic units have been divided into aquifers and confining units based upon water-yielding characteristics, with relatively high permeability layers forming aquifers and lowpermeability layers forming confining units. These sedimentary units unconformably overlie igneous, metamorphic, and sedimentary rocks of Paleozoic to Mesozoic age and reach a maximum thickness of 5,500 $\mathrm{ft}$ in Camden County (Wait and Davis, 1986). The thickness of sedimentary units varies and is influenced by major structural features in the area, such as the Southeast Georgia Embayment, Beaufort Arch, and Gulf Trough (fig. 1).

The Southeast Georgia Embayment (Miller, 1986) is a shallow east-to-northeast plunging syncline that accumulated Coastal Plain sediments to a maximum thickness in the Camden County area (fig. 1). It is postulated that subsidence occurred at a moderate rate from the Late Cretaceous to late Cenozoic, which allowed sediments to accumulate (Miller, 1986).

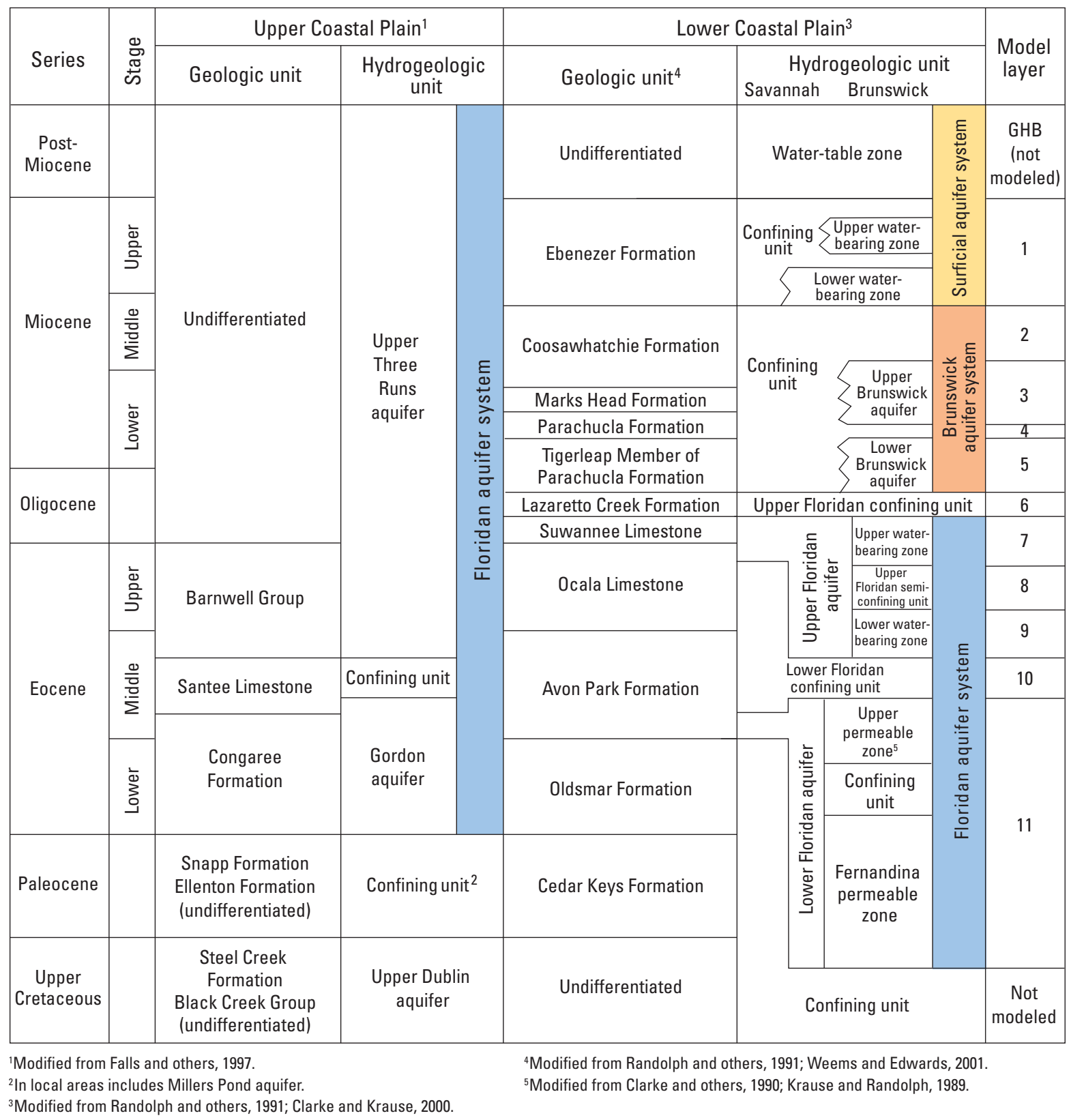

Figure 2. Generalized correlation chart of geologic and hydrogeologic units and model layers (modified from Payne and others, 2005; GHB, general-head boundary). 
The Beaufort Arch (Siple, 1960) elevated coastal plain sediments in the area northeast of Savannah, including Hilton Head Island, South Carolina (S.C.). The formation of the arch thinned Coastal Plain sediments and brought them close to land surface, where they dip and thicken southward toward the Southeast Georgia Embayment.

The Gulf Trough (Herrick and Vorhis, 1963) is a zone of low-permeability, fine-grained clastic sediments and clay-rich carbonates that act as a barrier and impede groundwater flow toward the coast. This feature is identified on potentiometric surfaces of the UFA as increased hydraulic gradients near the Gulf Trough that decrease south of the feature (Peck and McFadden, 2004).

Another feature, less prominent than the Gulf Trough, is the Satilla Line, which is a postulated hydrologic boundary identified by GaEPD that could influence groundwater flow in the UFA (fig. 1). The feature's existence is based on a change in the configuration of the potentiometric surface of the UFA, and by linear changes depicted on aeromagnetic, aeroradioactivity, gravity, and isopach maps; however, its geologic origin and nature are unknown.

The following descriptions of the surficial, Brunswick, and Floridan aquifer systems are based on their characteristics in the lower Coastal Plain physiographic province (fig. 2).

\section{Surficial Aquifer System}

The surficial aquifer system consists of interlayered lenses of sand, clay, and thin limestone beds of Miocene to Holocene age (Clarke, 2003). The surficial aquifer system contains a water-table zone and as many as two confined zones in the southern part of the study area where sediments are thickest (Southeast Georgia Embayment). In Glynn County, the surficial aquifer system contains a water-table zone and a single confined zone (Clarke and others, 1990). The reported transmissivity of the water-table zone ranges from 14 to 6,700 feet squared per day $\left(\mathrm{ft}^{2} / \mathrm{d}\right)$, whereas the reported transmissivity of the confined zone ranges from 150 to $6,000 \mathrm{ft}^{2} / \mathrm{d}$ (Clarke, 2003). In the original model, one confined zone is recognized and grouped into the upper model layer with the confining units of the surficial and Brunswick aquifer systems (Payne and others, 2005, fig. 2).

The surficial aquifer system is separated from the underlying Brunswick aquifer system by a confining unit consisting of silty clay and dense, phosphatic limestone of lower to middle Miocene age (fig. 2). Wait and Gregg (1973) reported the vertical hydraulic conductivity of this unit at Brunswick ranges from $5.3 \times 10^{-5}$ to $1.3 \times 10^{-4}$ feet per day $(\mathrm{ft} / \mathrm{d})$, as determined from laboratory analysis of core samples.

\section{Brunswick Aquifer System}

The Brunswick aquifer system consists of two waterbearing zones-the upper Brunswick aquifer and the lower Brunswick aquifer (fig. 2; Clarke, 2003). The upper Brunswick aquifer consists of poorly sorted, fine to coarse, slightly phosphatic and dolomitic quartz sand and dense phosphatic limestone (Clarke and others, 1990; Leeth, 1999). The lower Brunswick aquifer consists of poorly sorted, fine to coarse, phosphatic, dolomitic sand (Clarke and others, 1990). In general, the upper Brunswick aquifer is thinner, and as a result, has lower transmissivity than the lower Brunswick aquifer. Reported transmissivity of the upper Brunswick aquifer ranges from 20 to $3,500 \mathrm{ft}^{2} / \mathrm{d}$, whereas the reported transmissivity of the lower Brunswick aquifer ranges from 2,000 to 4,700 $\mathrm{ft}^{2} / \mathrm{d}$ (Clarke, 2003). The highest transmissivity values for both aquifers were reported near the Southeast Georgia Embayment where the units reach a maximum thickness in the Glynn County area (Clarke, 2003). The lower Brunswick confining unit (fig. 2) consists of weakly lithified shales and mudstones (Weems and Edwards, 2001). Outside the Southeast Georgia Embayment, the Brunswick aquifer system thins, or is discontinuous, and has a greater percentage of fine-grained sediments (Clarke, 2003). The original model of Payne and others (2005) considered the upper and the lower Brunswick aquifers as one model layer with combined thickness and one assigned hydraulic conductivity value. The current study subdivided this unit into two layers throughout the revised model to account for variability in layer thickness and hydraulic properties.

The Brunswick aquifer system is separated from the underlying Floridan aquifer system by a confining unit consisting of layers of silty clay and dense phosphatic dolomite of Oligocene age (fig. 2; Clarke, 2003). The reported vertical hydraulic conductivity of this confining unit ranges from $2.3 \times 10^{-4}$ to about $3 \mathrm{ft} / \mathrm{d}$ (Clarke and others, 2004), with one value estimated to be $1.1 \times 10^{-2} \mathrm{ft} / \mathrm{d}$ in the Brunswick area.

\section{Floridan Aquifer System}

The Floridan aquifer system consists of the UFA and Lower Floridan aquifer (LFA), which are composed of mostly Paleocene to Oligocene carbonate rocks that locally include Upper Cretaceous rocks (fig. 2; Miller, 1986; Krause and Randolph, 1989). The Floridan aquifer system extends from coastal areas in southeastern South Carolina, westward across the coastal plain of Georgia and Alabama, and southward, covering Florida. The thickness of the Floridan aquifer system in the model area varies from less than $100 \mathrm{ft}$ in aquifer outcrop areas of South Carolina to about 2,600 ft near the City of Brunswick (Krause and Randolph, 1989). 
The UFA is highly productive and consists of Eocene to Oligocene age limestone and dolomite (fig. 2; Clarke and others, 1990). The aquifer crops out at or near land surface in the northwestern part of the study area and near Valdosta in Lowndes County, Ga., where the aquifer is unconfined or semiconfined (fig. 1). To the southeast, the aquifer becomes progressively more deeply buried and confined. In this report, clastic sediments of the Upper Three Runs aquifer (Falls and others, 1997) in the upper Coastal Plain that are hydraulically connected to carbonate deposits of the lower Coastal Plain are included as part of the UFA (fig. 3). The transition from carbonate to clastic deposits generally occurs north of the Gulf Trough.

The reported transmissivity of the UFA and equivalent clastic units ranges from $530 \mathrm{ft}^{2} / \mathrm{d}$ in Beaufort County, S.C., to $600,000 \mathrm{ft}^{2} / \mathrm{d}$ in Coffee County, Ga. (Clarke and others, 2004). Large variability in the range of transmissivity where the UFA is largely composed of carbonate may indicate the influence of fractures or solution openings and related anisotropic distribution of hydraulic properties (Warner and Aulenbach, 1999; Clarke and others, 2004). Maslia (1987) attributed greater anisotropy between local- and regional-scale tests at the City of Brunswick to preferential flow along vertical solution channels associated with high-angle reverse faults and fractures.

In the original model (Payne and others, 2005), the UFA was simulated as a single layer. For this study, the aquifer was subdivided into the UWBZ and LWBZ as identified by Wait and Gregg (1973) in the Brunswick/Glynn County area (fig. 2). Wait and Gregg (1973) concluded the UWBZ is more productive, as indicated by pumping data from a well that tapped both zones; the upper zone contributed 70 percent of the flow and lower zone contributed the remainder. However, large cavities have been reported in the LWBZ and one cavity present at a depth of 945 to $947 \mathrm{ft}$ below land surface increased the flow from 600 gallons per minute ( $\mathrm{gal} / \mathrm{min}$ ) to 4,200 gal/min (Wait, 1965). In the Brunswick area, the UWBZ is about $165 \mathrm{ft}$ thick separated from the LWBZ by a semiconfining unit of about $160 \mathrm{ft}$ of soft dolostone (fig. 2; Jones and Maslia, 1994). Locally the LWBZ has a thickness of $100 \mathrm{ft}$ and extends to a depth of $970 \mathrm{ft}$. The UFA is underlain by a confining unit of dense recrystallized limestone and dolomite of middle to late Eocene age that hydraulically separates the UFA from the LFA by varying degrees (fig. 2). The UWBZ of the UFA is in the uppermost part of the Ocala Limestone and the Suwanee Limestone, which has been made extremely permeable by the development of secondary porosity caused by the migration of groundwater along bedding planes, joints, and fractures (L. Elliott Jones, U.S. Geological Survey, written commun., 2014).
Locally in the Brunswick area, the confining unit is breached by fractures or solution openings that enhance the exchange of water between the UFA and LFA (fig. 3; Krause and Randolph, 1989; Maslia and Prowell, 1990). These features probably have allowed saline water from the Fernandina permeable zone (described later) to migrate upward, primarily into the UWBZ of the UFA, where pressures are lower because of large-scale pumping by local industry. According to Maslia and Prowell (1990), four major northeast-southwest trending faults are indicated by geophysical data that show anomalous or irregular surfaces in the A-D marker beds near downtown Brunswick, which can be explained by a system of local folding and faulting. The marker beds, first recognized by Wait and Gregg (1973), represent natural gamma spikes interpreted as depositional unconformities that were created by a Miocene transgression. The marker beds form regular surfaces outside the Brunswick/Glynn County area. The LFA is composed mainly of dolomitic limestone of early and middle Eocene age; at the City of Brunswick, however, it includes highly permeable limestone of Paleocene and Late Cretaceous age (fig. 2; Krause and Randolph, 1989). In the northwestern part of the model area, the clastic Gordon aquifer (Brooks and others, 1985; Falls and others, 1997) is an updip unit that is hydraulically connected to the LFA (fig. 3). Reported transmissivity of the LFA ranges from $170 \mathrm{ft}^{2} / \mathrm{d}$ in Barnwell County, S.C., to 43,000 ft²/d in Camden County, Ga. (Clarke and others, 2004).

In southeastern Georgia and northeastern Florida, the LFA includes a saline water-bearing unit known as the Fernandina permeable zone, which is deeply buried, cavernous, and highly permeable (fig. 3; Krause and Randolph, 1989). The lateral extent of this unit is uncertain because a deep drilling program conducted for the Coastal Sound Science Initiative identified the unit near downtown Brunswick, but not farther north on St. Simons Island and in McIntosh County (Falls and others, 2005). The Fernandina permeable zone is present at a depth of about 2,100 ft in USGS 2,727-ft-deep test well (TW-26) on Colonels Island and is important in the Brunswick area because it is probably the local source of saline water (Jones and others, 2002). Maslia and Prowell (1990) postulated a system of vertical fractures and faults serve as a pathway for saline water migration from the Fernandina permeable zone into shallower units (fig. 3). Additional evidence of the presence of this unit was also obtained in deep test well (TW-26) on Colonels Island in Glynn County, about 3 mi west-southwest of downtown Brunswick. Acoustic televiewer images inside the borehole indicated the presence of large dissolution cavities at a depth of 2,475 ft near what appeared to be a high-angle fault and (or) fracture zones (Jones and others, 2002). 
Recharge area

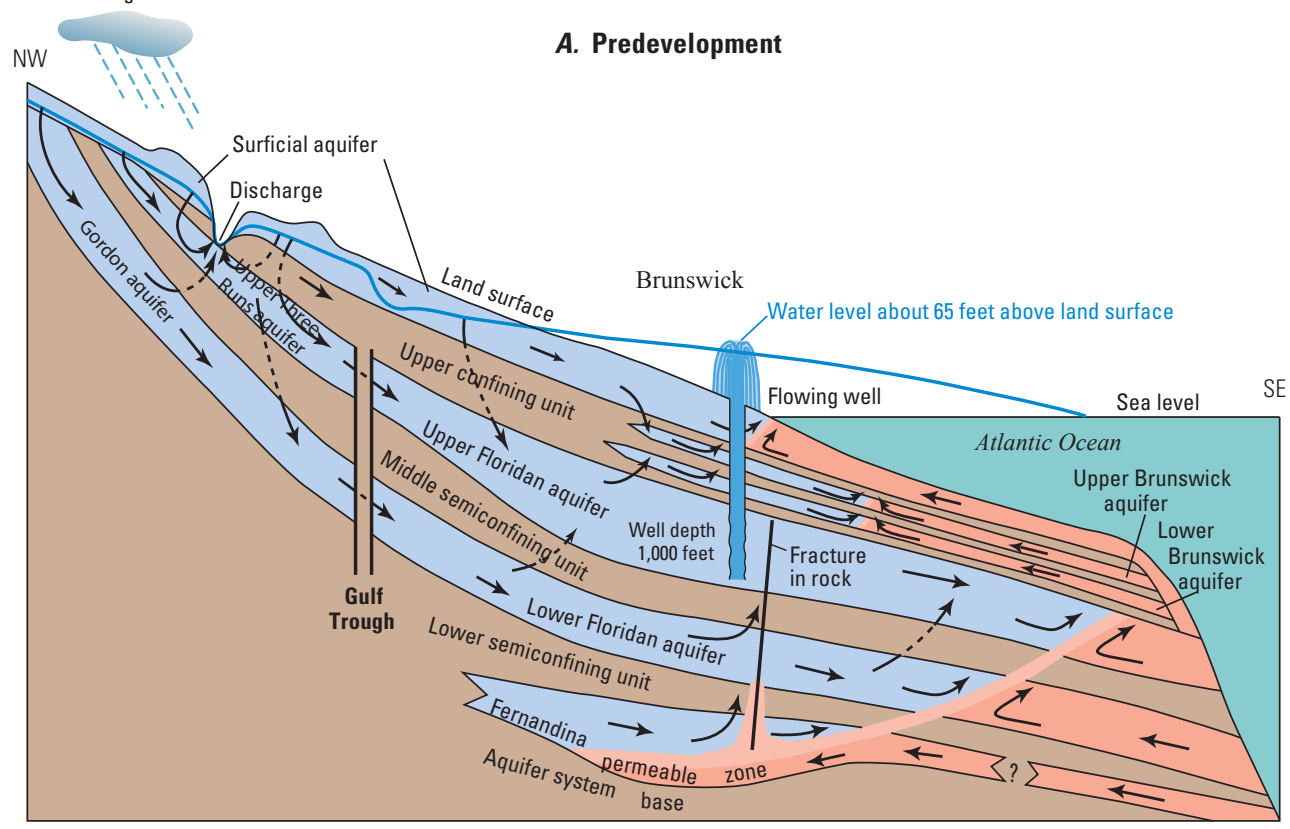

Recharge area

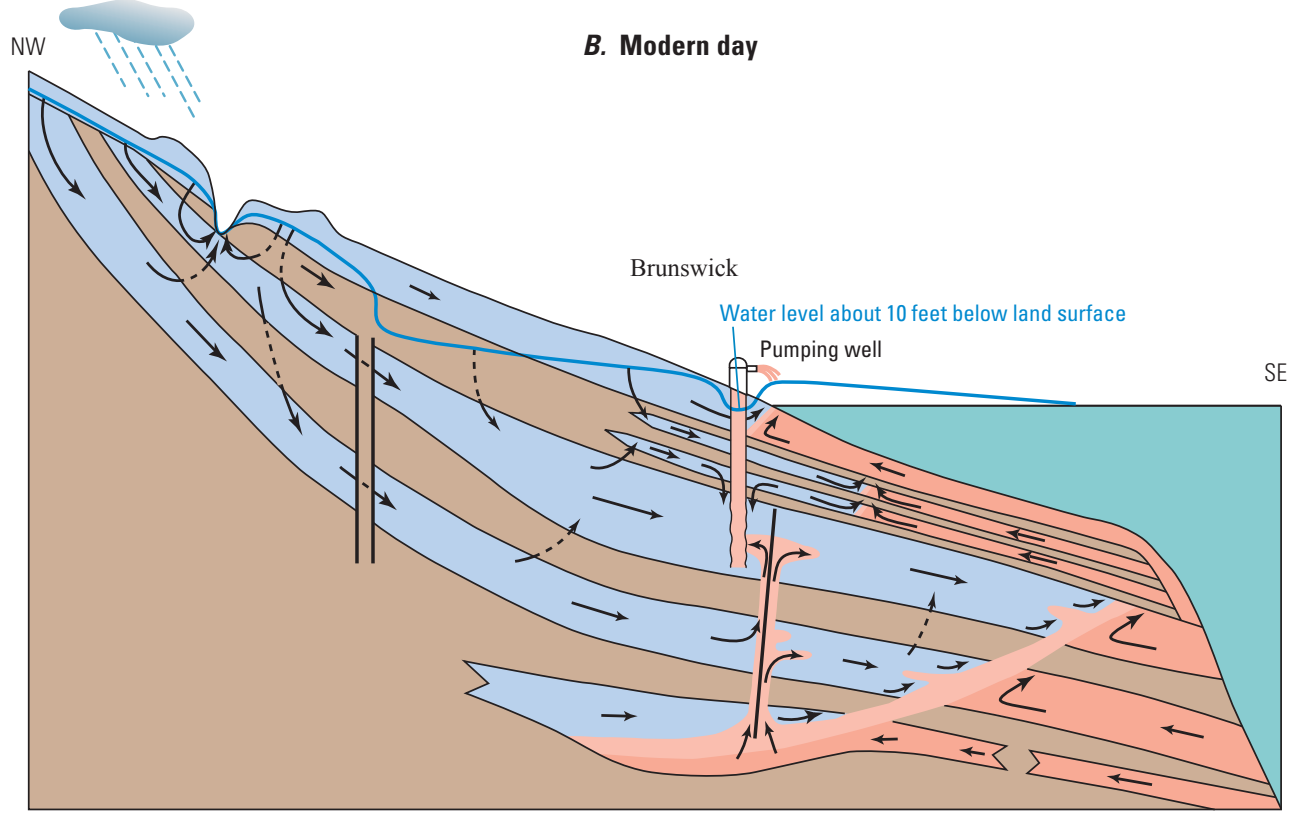

NOT TO SCALE

VERTICAL SCALE GREATLY EXAGGERATED

\section{EXPLANATION}

\begin{tabular}{l} 
Freshwater \\
\cline { 2 - 2 } $\begin{array}{l}\text { Slightly to moderately } \\
\text { saline water }\end{array}$ \\
Very saline water \\
Confining unit
\end{tabular}

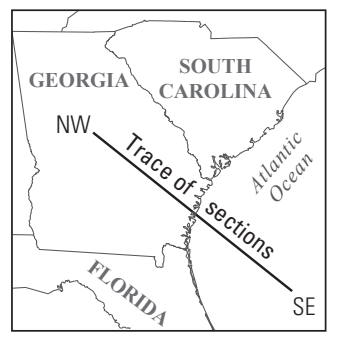

Figure 3. Schematic cross sections showing conceptual models of $A$, predevelopment (pre-1880s) and $B$, modern-day groundwater flow in the Floridan aquifer system from the outcrop area in the northwest (NW) to the offshore area in the southeast (SE), coastal Georgia (modified from Krause and Randolph, 1989). 


\section{Conceptualization of Groundwater Flow}

Most of groundwater recharge to the system occurs in outcrop areas of the Floridan aquifer system northwest of the Gulf Trough (fig. 3). Precipitation infiltrates land surface as direct recharge to the surficial aquifer and continues to flow downward into the deeper units. Some shallow flow paths capture infiltrating precipitation and contribute base flow locally to streams.

Prior to development, groundwater flow laterally descended toward the coast and then moved upward from deeper to shallower units near the ocean. Currently (2014), groundwater flow paths are influenced by pumping from the UFA, which has induced increased upward groundwater flow into the aquifer from the underlying Fernandina permeable zone through vertical fractures and faults (fig. 3). Maslia and Prowell (1990) postulated the location of four major northeastsouthwest-trending faults near the downtown Brunswick area, as well as fractures located at the intersection of these faults that have promoted the development of conduits, thereby allowing upward migration of saline groundwater into the UFA in response to pumping. This pumping in the UFA increased the natural upward hydraulic gradient from the Fernandina permeable zone toward the UFA and enhanced local groundwater flow from the overlying Brunswick aquifer system downward into the UFA to supply water to production wells.

Areas of groundwater recharge and discharge are influenced by outcrop locations of the hydrogeologic units and their subsurface extent beneath stream alluvium. Generally, recharge areas correspond to relatively high-altitude interstream divides, and discharge areas correspond to low-lying stream valleys (Clarke and West, 1998). Local recharge areas for the regional groundwater-flow system are south of the Fall Line and west of the Gulf Trough, with mean-annual recharge rates in the Savannah River Basin estimated at 14.5 inches per year (in/yr) (Faye and Mayer, 1990). East of the Gulf Trough, annual recharge to the regional groundwaterflow system ranges from near 0 to $2.4 \mathrm{in} / \mathrm{yr}$, as inferred from estimates of stream base flow during a drought period (Priest, 2004). Base-flow estimates determined by Priest (2004) at 14 streamgaging stations ranged from 4.4 to $10.0 \mathrm{in} / \mathrm{yr}$ and were used as annual recharge rates for the original groundwater-flow model (Payne and others, 2005).
Groundwater-flow directions and water quality in the regional aquifer system respond to changes in recharge and pumping. When pumping exceeds recharge, saline water migrates upward through a network of faults and fractures located near downtown Brunswick. When recharge exceeds pumping, freshwater moving through the aquifer system does not completely flush the saline water from the aquifer, and residual solute can remain for an extended period of time. This condition can contribute to the long-term degradation of the aquifer once saline water has migrated into the system from below.

\section{Chloride Contamination in the Brunswick Area}

In the Brunswick area, saline water has been contaminating the UFA since the late 1950s and has constrained development of the aquifer. During 2009, the chloride contamination covered a 2-mi ${ }^{2}$ area of downtown Brunswick and chloride concentrations within this area exceeded 2,000 mg/L (fig. 4; Cherry and others, 2011), well above the 250-mg/L State and Federal secondary drinking-water standard (Georgia Environmental Protection Division, 1997; U.S. Environmental Protection Agency, 2000).

Since the late 1950s, the USGS has collected water samples from the UFA in the Brunswick area and documented increasing chloride concentrations in response to increased groundwater withdrawals (fig. 4). Pumping resulted in lowered water levels and an upward hydraulic gradient between the saline portions of the Fernandina permeable zone and the normally fresh UFA. Saline water probably is entering the UFA through localized, vertically oriented conduits of relatively high permeability and moving laterally in response to pumpage within the UWBZ. Acoustic televiewer images from test well 33H188 (TW-26) provide evidence of features that appear to be high-angle fault and/or fracture zones at a depth near 2,475 ft (Jones and others, 2002). The chloride concentration of sea water is about $20,000 \mathrm{mg} / \mathrm{L}$, and the water taken from the bottom of the Fernandina permeable zone at test well $33 \mathrm{H} 188$ was about $30,000 \mathrm{mg} / \mathrm{L}$ in 1982 (Krause and Randolph, 1989). The chloride plume has stabilized in recent years, most likely because local horizontal hydraulic gradients have been maintained and groundwater withdrawals by local industry and by regional groundwater users over the coastal region have decreased (Cherry, 2007; Cherry and Clarke, 2008; Cherry and others, 2010 and 2011). 


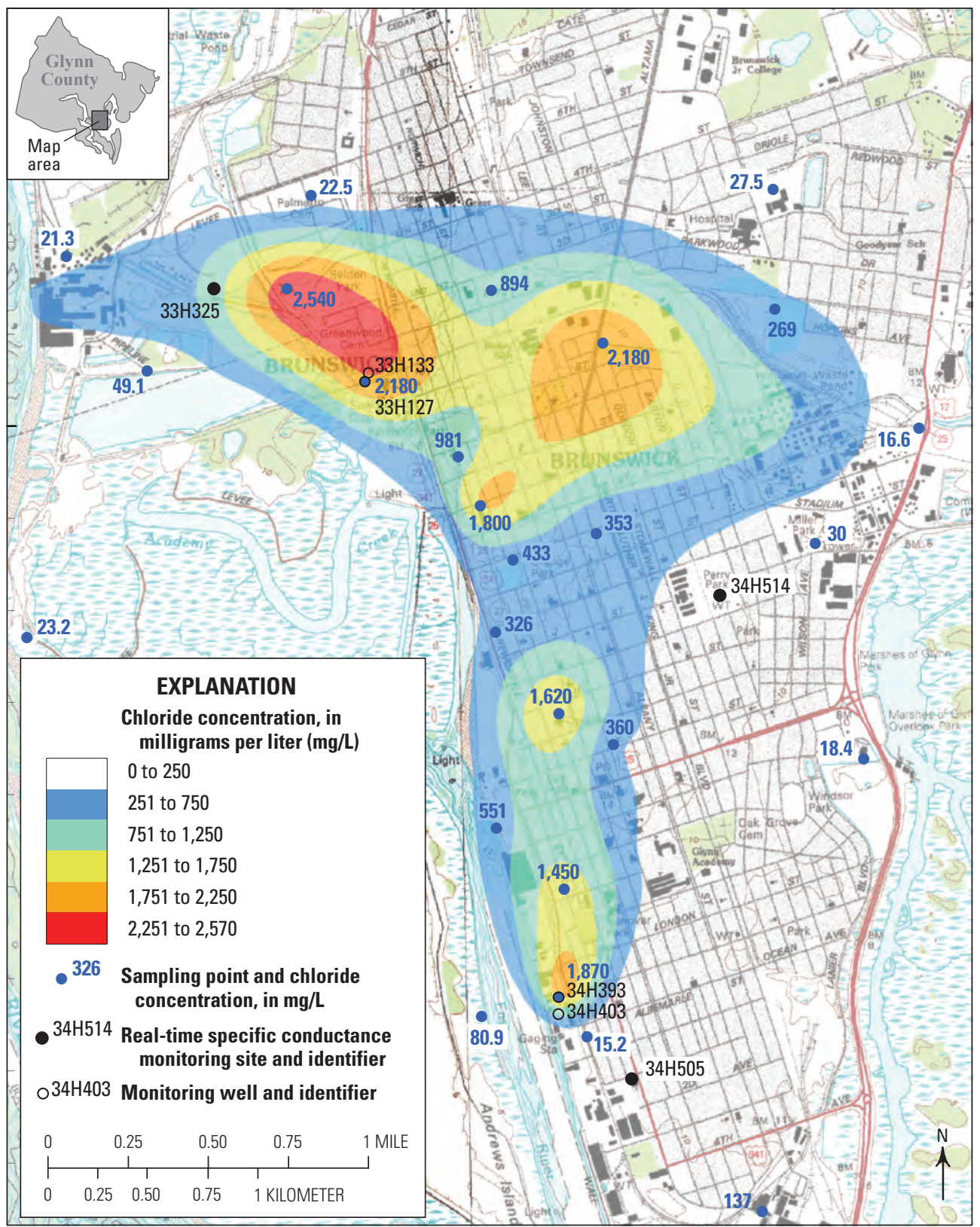

Base from U.S. Geological Survey digital files, 1:24,000, Brunswick West, 1993; Brunswick East, 1979
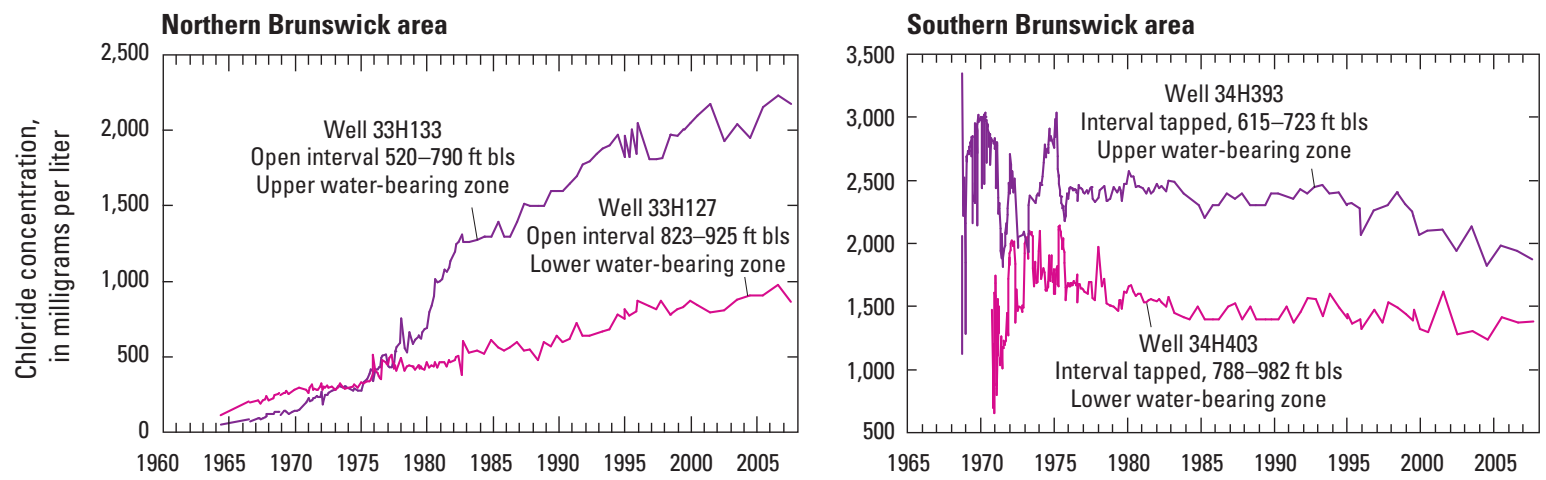

Figure 4. Chloride concentrations in the Upper Floridan aquifer near the downtown Brunswick area, August 2007, and chloride concentration in water for selected wells in the northern and southern Brunswick area, 1964-2007. 


\section{Groundwater Use and Water Levels, 2000-04}

The location and magnitude of groundwater withdrawals at pumping centers may affect groundwater levels substantially in the Brunswick/Glynn County area. Changes in pumping rates and the addition of new pumping centers may alter the configuration of potentiometric surfaces, reverse groundwater-flow directions, and increase seasonal and longterm water-level fluctuations in the aquifers. During 2000-04, groundwater levels in the UFA in the Brunswick/Glynn County area were affected by the shutdown of the Durango Paper Company mill near St. Marys, Ga. (fig. 1). In addition, a prolonged drought adversely affected groundwater levels during 1998-2002. The following sections describe changes to groundwater use and groundwater levels during the 5-year period of model simulation.

\section{Groundwater Use}

The UFA and LFA supply the study area with sufficient quantities of groundwater, with average withdrawals during 2000 totaling 682 and 133 million gallons per day (Mgal/d), respectively (Payne and others, 2005). Groundwater withdrawals from the UFA and LFA in 2004 were less than during 2000, with average withdrawals totaling 612 and $116 \mathrm{Mgal} / \mathrm{d}$, respectively. Pumping from the UFA and LFA during 1980 2004 is summarized in table 1 and shown in figure $5 \mathrm{~A}$, both of which indicate groundwater use increasing steadily and peaking during 2000. Considerably less groundwater was withdrawn from the Brunswick aquifer system during 2004 $(1.75 \mathrm{Mgal} / \mathrm{d})$ than from the UFA and LFA, although withdrawals from the Brunswick aquifer system have increased since 2000 as a result of GaEPD restrictions on further development of the UFA.

County aggregate and site-specific data were used to estimate average annual pumpage for 2000 and 2004 using procedures described by Taylor and others (2003). Groundwater-use data for 2000 were based on county aggregate pumping estimates for Florida (Marella, 2004), Georgia (Fanning; 2003), and South Carolina (W.L. Stringfield, U.S. Geological Survey, written commun., 2002). Site-specific data along with pumping rates were compiled for Georgia (J.L. Fanning, U.S. Geological Survey, written commun., 2002), South Carolina (P. Bristol, South Carolina Department of Health and Environmental Control, written commun., 2003), and Florida (Sepúlveda, 2002). Pumping estimates for 2004 reflect a combination of site-specific data for 2004 (J.L. Fanning,

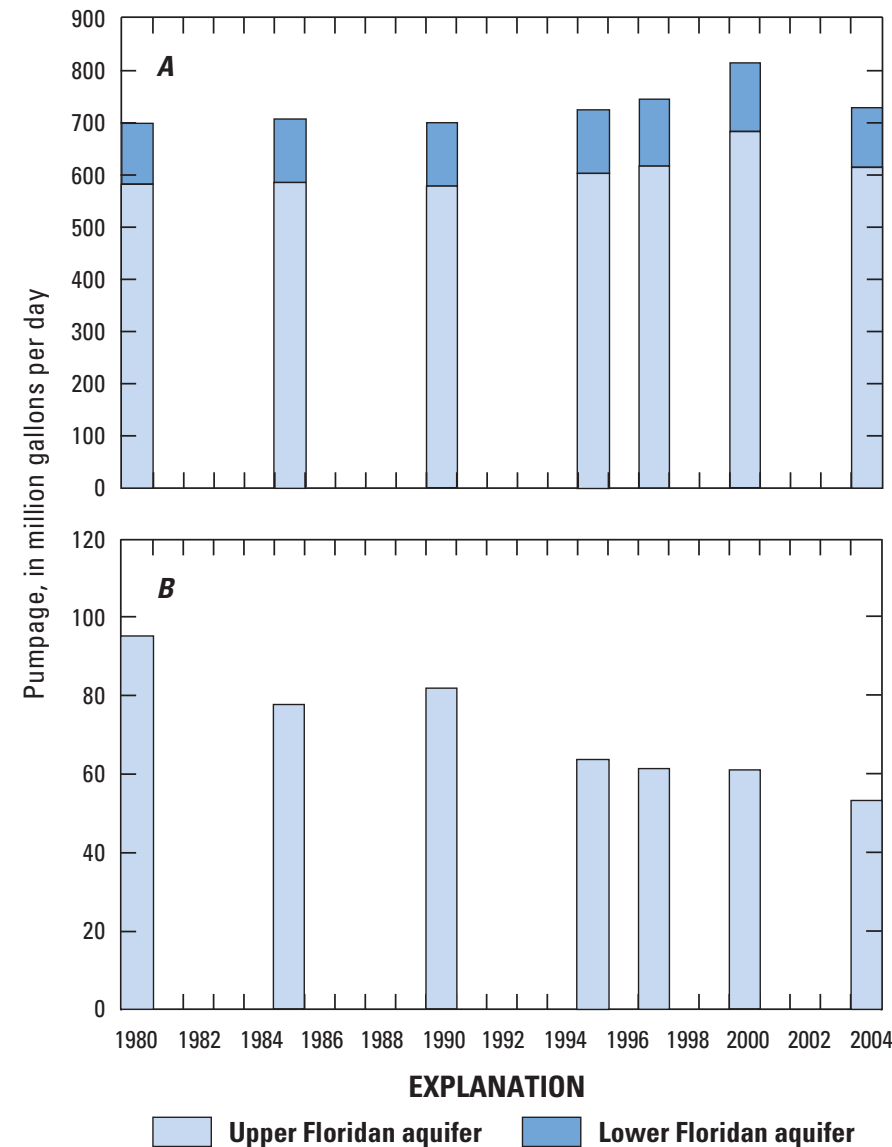

Figure 5. Estimated groundwater pumpage from the $A$, Upper and Lower Floridan aquifers in the model area, and $B$, Upper Floridan aquifer in the Glynn County area, 1980-2004. Table 1 provides county totals and data sources.

U.S. Geological Survey, written commun., 2006; P. Bristol, South Carolina Department of Health and Environmental Control, written commun., 2006; R.L. Marella, U.S.

Geological Survey, written commun., 2006) and county aggregate data for 2000 (Marella, 2004; Fanning, 2003; W.L. Stringfield, U.S. Geological Survey, written commun., 2002). Because county aggregate data were not available for 2004, county aggregate estimates for 2000 were used as a basis for estimating usage for 2004. Use of these data for both time periods is considered reasonable for Glynn County because agricultural pumpage in the county is minimal, and rural population (domestic supply) showed little change during this period. In other parts of the coastal area, use of aggregate data for 2000 could have resulted in an overestimation of water use during 2004 because generally wetter conditions existed during 2004 compared to 2000. 
Along the Georgia coast, the estimated pumping distributions during 2000 and 2004 were comparable at major pumping centers located near Savannah, Jesup, and Brunswick, Ga. Concerns about overdevelopment of the UFA prompted the GaEPD to implement an interim water management plan for coastal Georgia (Georgia Environmental Protection Division, 2005), which restricted withdrawal from the UFA in parts of the coastal area, resulting in decreased withdrawals overall (fig. 5).

In general, permitted groundwater withdrawals have decreased across the State since 2001 by about 12 percent because of conservation efforts made by industrial and municipal users (Leeth and others, 2007). The largest change in water use in coastal Georgia during 2000-04 was attributed to the shutdown of the Durango Paper Company mill in October 2002, which deactivated production wells at the facility. The paper mill near St. Marys was about $30 \mathrm{mi}$ south of the City of Brunswick, and pumped $35.5 \mathrm{Mgal} / \mathrm{d}$ from the UFA while in operation (Peck and others, 2004).

Groundwater is an important resource in counties located along coastal Georgia and parts of coastal areas in Florida and South Carolina because of population growth and industrial development. The largest withdrawals from the UFA in 2004 occurred in Chatham (63 Mgal/d), Wayne (63 Mgal/d), and Glynn (54 Mgal/d) Counties, Ga. During 2000-04, the largest change in pumpage occurred in Camden County, which decreased from $51 \mathrm{Mgal} / \mathrm{d}$ in 2000 to $6.3 \mathrm{Mgal} / \mathrm{d}$ in 2004, with most of the decrease attributed to the shutdown of the Durango Paper Company mill in October 2002 (Peck and others, 2004). Average daily pumpage from the UFA and its updip equivalents during 2004 exceeded $10 \mathrm{Mgal} / \mathrm{d}$ in Duval and Nassau Counties, Fla.; in Beaufort County, S.C.; and in Burke, Chatham, Coffee, Dooly, Glynn,
Jefferson, Liberty, Pulaski, Screven, Washington, Wayne, and Wilcox Counties, Ga. (table 1). Average daily pumpage in the LFA and its updip equivalents during 2004 exceeded $1 \mathrm{Mgal} / \mathrm{d}$ in Duval and Nassau Counties, Fla.; and in Burke, Coffee, Crisp, Dooly, Jefferson, Laurens, Pulaski, Screven, Washington, and Wilcox Counties, Ga. (table 1). The largest withdrawal from the LFA during 2004 occurred in Duval County, Fla., where pumpage exceeded $82 \mathrm{Mgal} / \mathrm{d}$ (table 1).

During 1980-2000, total daily pumpage from the UFA increased by 17 percent, from $583 \mathrm{Mgal} / \mathrm{d}$ during 1980, to a peak of $682 \mathrm{Mgal} / \mathrm{d}$ during 2000 (Payne and others, 2005). During 2004, estimated total daily pumpage from the UFA decreased to about $612 \mathrm{Mgal} / \mathrm{d}$. The reduction could be lower than $612 \mathrm{Mgal} / \mathrm{d}$ because the 2000 aggregate water-use rate used for the 2004 estimate does not account for possible reduced agricultural usage that could have resulted from the generally wetter 2004 conditions compared with 2000.

Withdrawals from the LFA during 1980-2004 showed a similar pattern to those from the UFA. Estimated withdrawals from the LFA increased by 14 percent from a low of $117 \mathrm{Mgal} / \mathrm{d}$ during 1980 to a peak of $133 \mathrm{Mgal} / \mathrm{d}$ during 2000 (Payne and others, 2005), followed by a decrease to $116 \mathrm{Mgal} / \mathrm{d}$ during 2004 (table 1).

During 2000-04, total pumpage from the Brunswick aquifer system increased from $0.24 \mathrm{Mgal} / \mathrm{d}$ during 2000 to $3.25 \mathrm{Mgal} / \mathrm{d}$ during 2004 (Payne and others, 2005; Vicki Trent, Georgia Environmental Protection Division, written commun., November 15, 2010). The pumpage increase for the Brunswick aquifer can be attributed to greater use for golf-course irrigation in the Glynn County area and recently constructed public-supply wells in the Golden Isles area of Glynn County (Cherry and others, 2011). 
Table 1. Estimated groundwater pumpage from the Upper and Lower Floridan aquifers in the coastal area of Georgia and adjacent parts of South Carolina and Florida, 1980-2004.

[UFA, Upper Floridan aquifer; LFA, Lower Floridan aquifer]

\begin{tabular}{|c|c|c|c|c|c|c|}
\hline \multirow{3}{*}{ County } & \multicolumn{6}{|c|}{ Pumpage, in million gallons per day } \\
\hline & \multicolumn{2}{|c|}{1980} & \multicolumn{2}{|c|}{1985} & \multicolumn{2}{|c|}{1990} \\
\hline & UFA & LFA & UFA & LFA & UFA & LFA \\
\hline Baker & 1.72 & 0.26 & 2.88 & 0.43 & 3.68 & 0.55 \\
\hline Columbia & 3.05 & 0.00 & 4.79 & 0.00 & 5.07 & 0.00 \\
\hline Hamilton & 0.10 & 0.00 & 0.30 & 0.00 & 0.44 & 0.00 \\
\hline Nassau & 44.09 & 2.51 & 46.76 & 2.16 & 49.72 & 2.00 \\
\hline \multicolumn{7}{|c|}{ Georgia } \\
\hline Appling & 5.71 & 0.00 & 2.60 & 0.00 & 2.10 & 0.00 \\
\hline Berrien & 2.43 & 0.41 & 3.26 & 0.53 & 2.80 & 0.45 \\
\hline Bleckley & 5.59 & 0.87 & 4.28 & 0.63 & 3.29 & 0.41 \\
\hline Brantley & 1.46 & 0.00 & 1.63 & 0.00 & 1.83 & 0.00 \\
\hline Bryan & 0.67 & 0.00 & 0.87 & 0.00 & 1.03 & 0.00 \\
\hline Bulloch & 3.75 & 0.23 & 2.71 & 0.20 & 5.87 & 0.16 \\
\hline Burke & 10.30 & 1.60 & 6.34 & 0.92 & 5.82 & 0.83 \\
\hline Camden & 37.12 & 0.00 & 42.98 & 0.00 & 45.74 & 0.00 \\
\hline Candler & 1.83 & 0.26 & 2.57 & 0.34 & 1.64 & 0.17 \\
\hline Dodge & 7.02 & 1.01 & 3.95 & 0.52 & 2.40 & 0.22 \\
\hline Dooly & 6.30 & 0.96 & 9.45 & 1.46 & 3.18 & 0.41 \\
\hline Echols & 0.17 & 0.00 & 0.18 & 0.00 & 0.25 & 0.00 \\
\hline Effingham & 2.26 & 0.02 & 2.06 & 0.01 & 4.98 & 0.03 \\
\hline Emanuel & 7.34 & 0.85 & 5.30 & 0.68 & 4.18 & 0.36 \\
\hline Evans & 0.38 & 0.05 & 0.31 & 0.04 & 0.38 & 0.05 \\
\hline Glascock & 0.73 & 0.04 & 0.72 & 0.02 & 0.99 & 0.02 \\
\hline Glynn & 95.40 & 0.00 & 77.84 & 0.00 & 82.02 & 0.00 \\
\hline Irwin & 1.96 & 0.25 & 1.86 & 0.21 & 2.15 & 0.26 \\
\hline Jeff Davis & 5.11 & 0.81 & 5.80 & 0.89 & 4.77 & 0.66 \\
\hline Jefferson & 4.97 & 0.69 & 9.90 & 1.44 & 8.85 & 1.03 \\
\hline Jenkins & 2.74 & 0.41 & 2.65 & 0.37 & 2.45 & 0.33 \\
\hline Johnson & 1.37 & 0.17 & 1.81 & 0.26 & 0.92 & 0.12 \\
\hline
\end{tabular}


Table 1. Estimated groundwater pumpage from the Upper and Lower Floridan aquifers in the coastal area of Georgia and adjacent parts of South Carolina and Florida, 1980-2004.-Continued

[UFA, Upper Floridan aquifer; LFA, Lower Floridan aquifer]

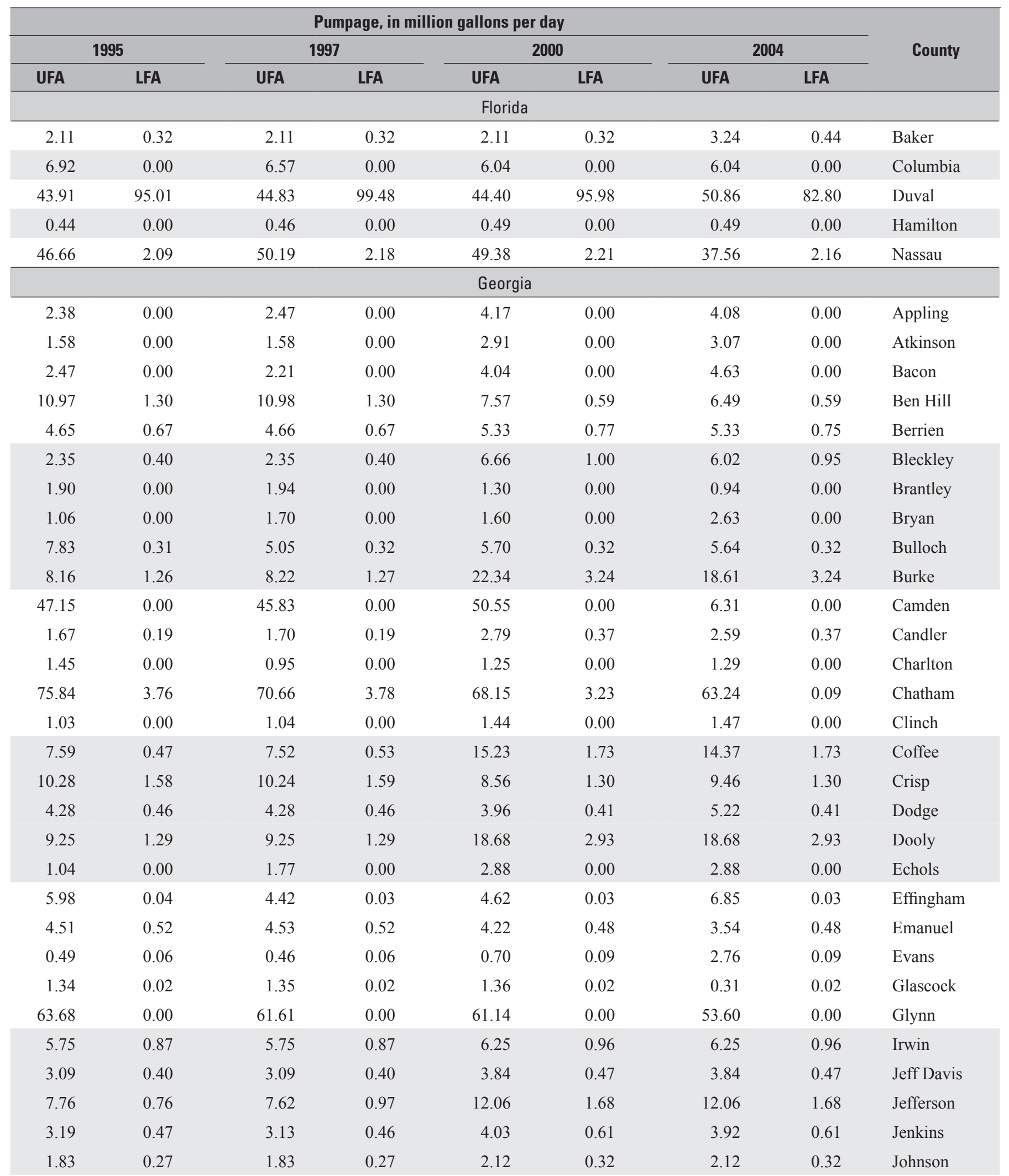


Table 1. Estimated groundwater pumpage from the Upper and Lower Floridan aquifers in the coastal area of Georgia and adjacent parts of South Carolina and Florida, 1980-2004.-Continued

[UFA, Upper Floridan aquifer; LFA, Lower Floridan aquifer]

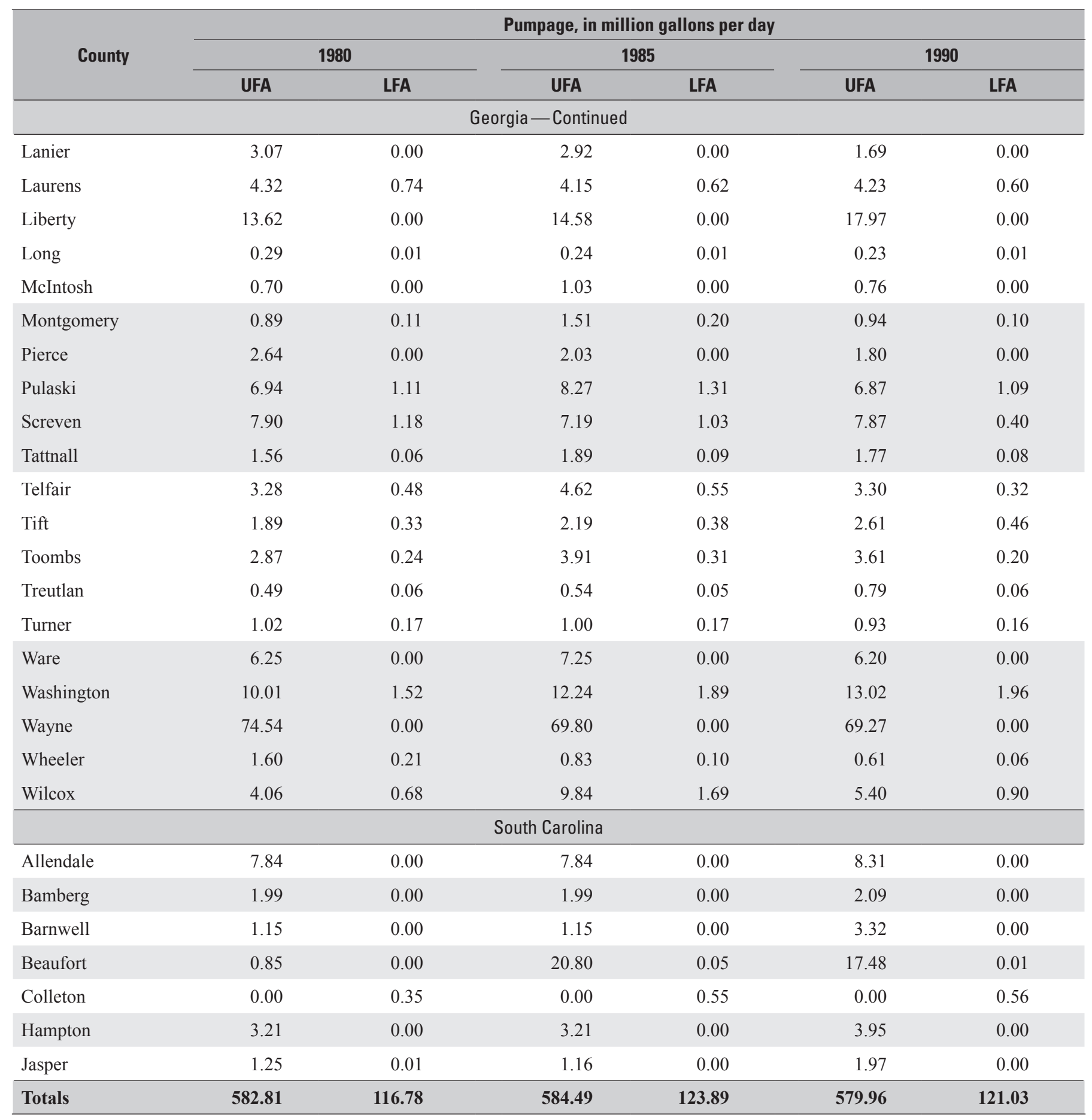


Table 1. Estimated groundwater pumpage from the Upper and Lower Floridan aquifers in the coastal area of Georgia and adjacent parts of South Carolina and Florida, 1980-2004.-Continued

[UFA, Upper Floridan aquifer; LFA, Lower Floridan aquifer]

\begin{tabular}{|c|c|c|c|c|c|c|c|c|}
\hline \multicolumn{8}{|c|}{ Pumpage, in million gallons per day } & \multirow{3}{*}{ County } \\
\hline \multicolumn{2}{|c|}{1995} & \multicolumn{2}{|c|}{1997} & \multicolumn{2}{|c|}{2000} & \multicolumn{2}{|c|}{2004} & \\
\hline UFA & LFA & UFA & LFA & UFA & LFA & UFA & LFA & \\
\hline 2.02 & 0.00 & 2.02 & 0.00 & 1.97 & 0.00 & 1.72 & 0.00 & Lanier \\
\hline 5.78 & 0.97 & 5.81 & 0.95 & 7.94 & 1.31 & 7.96 & 1.31 & Laurens \\
\hline 0.27 & 0.02 & 0.27 & 0.02 & 0.69 & 0.07 & 1.20 & 0.07 & Long \\
\hline 1.07 & 0.00 & 1.09 & 0.00 & 0.85 & 0.00 & 0.94 & 0.00 & McIntosh \\
\hline 2.40 & 0.33 & 2.40 & 0.33 & 1.61 & 0.19 & 1.61 & 0.19 & Montgomery \\
\hline 3.24 & 0.00 & 3.42 & 0.00 & 6.22 & 0.00 & 6.18 & 0.00 & Pierce \\
\hline 3.53 & 0.28 & 3.59 & 0.28 & 3.66 & 0.15 & 2.74 & 0.15 & Tattnall \\
\hline 6.33 & 0.83 & 6.33 & 0.82 & 4.00 & 0.42 & 4.36 & 0.42 & Telfair \\
\hline 3.95 & 0.69 & 3.80 & 0.66 & 3.57 & 0.62 & 3.57 & 0.62 & Tift \\
\hline 3.65 & 0.27 & 4.17 & 0.27 & 6.30 & 0.69 & 6.64 & 0.69 & Toombs \\
\hline 1.31 & 0.12 & 1.31 & 0.12 & 1.10 & 0.11 & 1.13 & 0.11 & Treutlan \\
\hline 2.91 & 0.50 & 2.92 & 0.50 & 2.57 & 0.44 & 2.57 & 0.44 & Turner \\
\hline 5.51 & 0.00 & 5.97 & 0.00 & 8.45 & 0.00 & 5.82 & 0.00 & Ware \\
\hline 14.39 & 2.16 & 14.88 & 2.04 & 16.01 & 2.07 & 16.01 & 2.07 & Washington \\
\hline 2.52 & 0.00 & 4.04 & 0.00 & 6.32 & 0.00 & 6.32 & 0.00 & Bamberg \\
\hline 2.91 & 0.00 & 4.90 & 0.00 & 7.50 & 0.00 & 7.39 & 0.00 & Barnwell \\
\hline 19.56 & 0.01 & 33.58 & 0.09 & 21.44 & 0.26 & 18.21 & 0.03 & Beaufort \\
\hline 0.00 & 0.58 & 0.00 & 0.47 & 0.00 & 0.51 & 0.15 & 0.24 & Colleton \\
\hline 4.32 & 0.00 & 5.99 & 0.00 & 8.63 & 0.00 & 7.97 & 0.00 & Hampton \\
\hline 1.31 & 0.00 & 2.13 & 0.01 & 3.34 & 0.01 & 2.80 & 0.01 & Jasper \\
\hline 603.42 & 123.02 & 616.62 & 127.75 & 682.31 & 132.71 & 612.13 & 115.94 & Totals \\
\hline
\end{tabular}




\section{Groundwater Levels}

Groundwater levels vary seasonally and are affected by precipitation, evapotranspiration, and pumping. Groundwater levels generally are highest in the winter through early spring when evapotranspiration is lowest and irrigation withdrawals are minimal; groundwater levels are lowest during summer and fall when evapotranspiration and pumping rates are highest. A map and water-level hydrographs for selected wells in the Brunswick aquifer system, UFA, and LFA during 2000-04 for Glynn County are shown in figure 6.

During 2003-04, above-normal rainfall following the drought of 1998-2002 and the reduction in groundwater withdrawals from major aquifers resulted in increased water levels. Some wells recorded historic lows during the fall of 2002, but recovered to near normal levels, or in some cases above-normal levels in 2004 (Leeth and others, 2007). The most pronounced water-level rise was in the St. Marys, Camden County area, in response to closure of the Durango Paper Company mill in October 2002, which resulted in a water-level rise of more than $200 \mathrm{ft}$ at the center of the cone of depression and water-level increases ranging from 4 to $10 \mathrm{ft}$ in outlying areas of Camden County (Peck and others, 2004). During 2003-04, above-normal rainfall ended the cycle of drought in Georgia that lasted from 1998 to 2002. The rainfall amounts for 2003 at 10 stations located in hydrogeologic unit areas of outcrop (aquifer-recharge zones) ranged from 8 to 34 percent above normal (The Southeast Regional Climate Center, 2009). As a result of the increase in rainfall and recharge to the regional aquifer system, water levels for June 2004 in the Brunswick aquifer system, UFA, and LFA (fig. 6) generally were higher than during 2000. The exceptions occurred in two wells in the Savannah area (39Q026 and 39Q028) having open intervals in the Brunswick aquifer system and one well in Effingham County, (35T003) completed in the UFA, which indicated water-level declines from in 2000 to 2004. These wells could be influenced by localized pumping.

Data from eight observation wells open to the Brunswick aquifer system indicate a general water-level rise during
2000-04 throughout the study area (table 2). Overall, the differences in water-level measurements from 2000 to 2004 range from $-1.04 \mathrm{ft}$ (well 39Q028; Chatham County) to $19.29 \mathrm{ft}$ (well 33D071; Camden County), with an average increase of $3.97 \mathrm{ft}$. In the Brunswick/Glynn County area, water levels in two observation wells rose $3.04 \mathrm{ft}$ (well 34H437) and $4.56 \mathrm{ft}$ (well 33G028) over the 5-year period (table 3). Graphs for wells 33J062 and 34H492, completed in the lower Brunswick and surficial aquifers, respectively, show waterlevel rises during 2000-04, with most of the rise occurring during 2002 (fig. 6). The largest rise occurred in well 33J062, located in the western part of Glynn County, away from any pumping centers.

In the UWBZ, water-level measurements taken in 35 wells during 2000-04 indicate water-level declines and rises ranging from -29.29 to $11.84 \mathrm{ft}$, respectively, with an average water-level rise of $4.03 \mathrm{ft}$ (table 2). In the Brunswick/ Glynn County area, water levels in 19 wells completed in the UWBZ rose from 1.05 to $7.93 \mathrm{ft}$, with an average water-level rise of $4.94 \mathrm{ft}$ (table 3). Water levels in well $33 \mathrm{H} 133$ show a water-level rise during 2000-04, with about $6 \mathrm{ft}$ of the rise occurring during 2002 (fig. 6). Water-level data for the LWBZ are sparse but indicate a water-level rise of $7.25 \mathrm{ft}$ in one well in downtown Brunswick (33H127; table 3; fig. 6), which is consistent with water-level changes in the overlying UWBZ of the UFA.

In the LFA, 2000 and 2004 water-level data from eight observation wells indicate rises ranging from 1.73 to $27.09 \mathrm{ft}$, with an average increase of $7.14 \mathrm{ft}$ (table 2). The $27.09-\mathrm{ft}$ water-level rise observed in well 33D073 was due, in part to the shutdown of the Durango Paper Company mill during 2002 (Peck and others, 2004). In the Brunswick/Glynn County area, 2000 and 2004 water-level data from five observation wells indicate water-level rises ranging from 2.69 to $7.68 \mathrm{ft}$, with an average increase of $5.06 \mathrm{ft}$ (table 3). Water levels in LFA well 34H436 rose during 2000-04, with most of the increase occurring during 2002 (fig. 6). In well 33H188, completed in the Fernandina permeable zone of the LFA, water levels declined from 2000 through early 2002, followed by a sharp rise thereafter (fig. 6). 

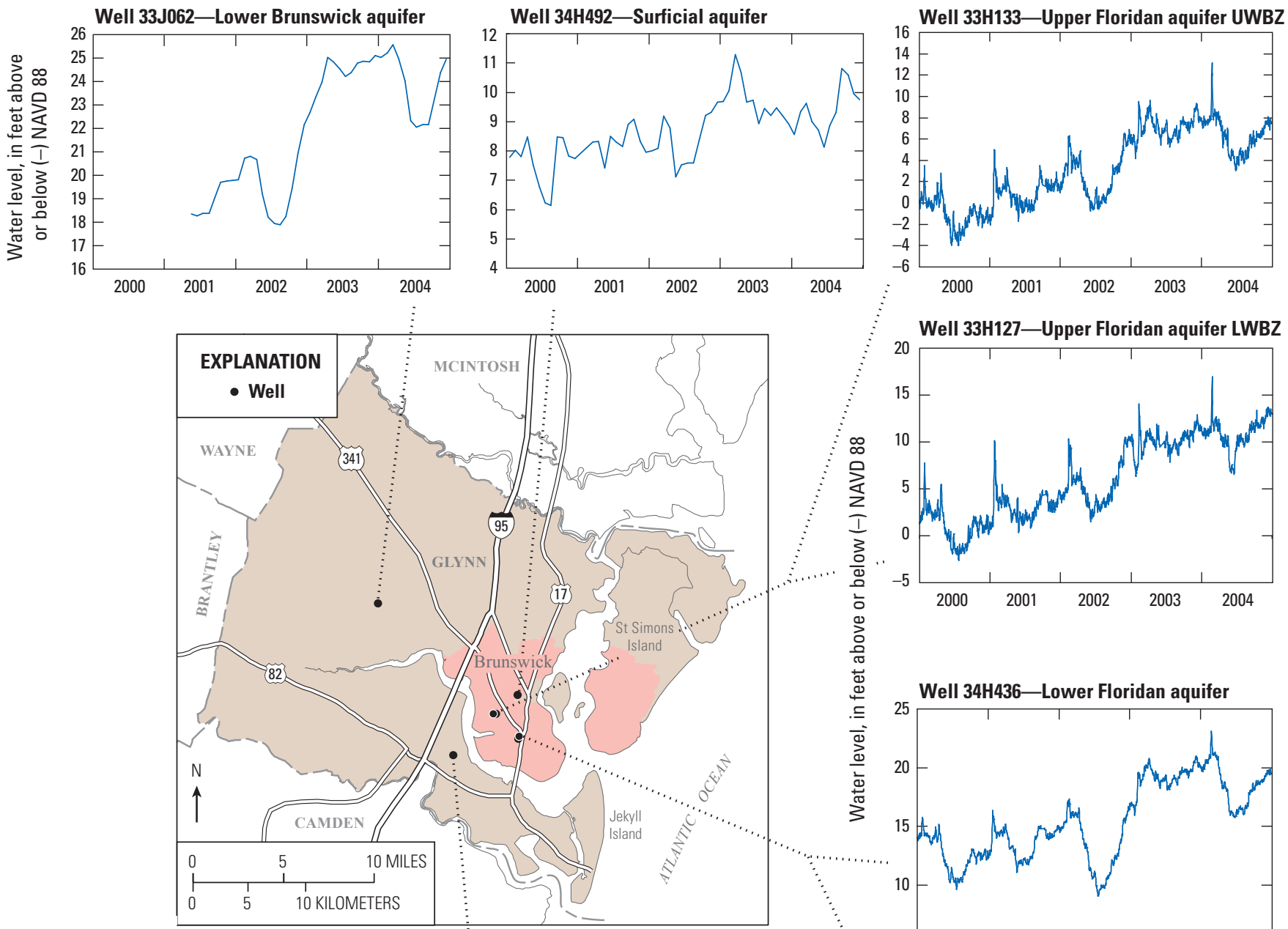

Base modified from U.S. Geological Survey, 1:100,000-scale digital data

Well 33H127-Upper Floridan aquifer LWBZ
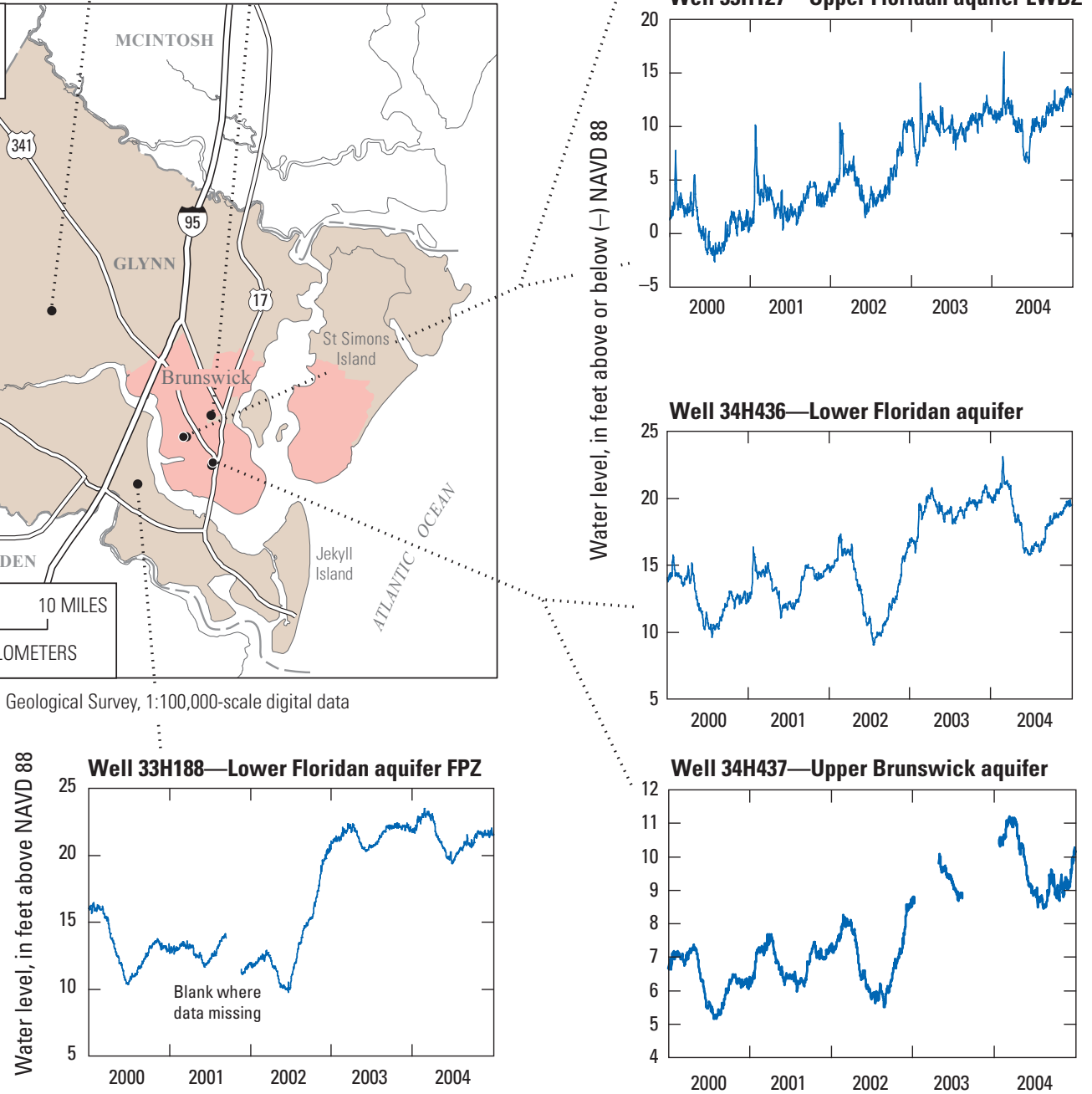

Figure 6. Selected water-level hydrographs for the surficial aquifer, upper Brunswick aquifer, lower Brunswick aquifer, Upper Floridan aquifer upper water-bearing zone (UWBZ), Upper Floridan aquifer lower water-bearing zone (LWBZ), Lower Floridan aquifer, and Lower Floridan aquifer Fernandina permeable zone (FPZ), in the Brunswick/Glynn County, Georgia area, 2000-04. 
Table 2. Water-level measurements taken during 2000 and 2004 and observed water-level change during the same period.

[NAVD 88, North American Vertical Datum of 1988; see fig. 2-1 for well locations]

\begin{tabular}{|c|c|c|c|c|}
\hline \multirow{2}{*}{$\begin{array}{l}\text { Well } \\
\text { identifier }\end{array}$} & \multirow[t]{2}{*}{ County } & \multicolumn{2}{|c|}{$\begin{array}{c}\text { Water level, } \\
\text { in feet above or below NAVD } 88\end{array}$} & \multirow{2}{*}{$\begin{array}{l}\text { Water-level change } \\
\text { from } 2000 \text { to } 2004, \\
\text { in feet }\end{array}$} \\
\hline & & 2000 & 2004 & \\
\hline \multicolumn{5}{|c|}{ Upper Brunswick aquifer (UBA) } \\
\hline 32L016 & Wayne & 15.79 & 17.60 & 1.81 \\
\hline 33D071 & Camden & -2.07 & 17.22 & 19.29 \\
\hline $33 \mathrm{G} 028$ & Glynn & 16.75 & 21.31 & 4.56 \\
\hline $34 \mathrm{H} 437$ & Glynn & 5.88 & 8.92 & 3.04 \\
\hline 39Q026 & Chatham & -2.31 & -3.29 & -0.98 \\
\hline 39Q028 & Chatham & -2.21 & -3.25 & -1.04 \\
\hline $35 \mathrm{~S} 008$ & Effingham & 12.09 & 13.42 & 1.33 \\
\hline $36 \mathrm{~N} 012$ & Bryan & -26.18 & -22.43 & 3.75 \\
\hline & & & UBA mean & 3.97 \\
\hline \multicolumn{5}{|c|}{ Upper water-bearing zone of Upper Floridan aquifer (UWBZUFA) } \\
\hline $21 \mathrm{~T} 001$ & Laurens & 220.19 & 223.66 & 3.47 \\
\hline 26R001 & Toombs & 103.85 & 106.63 & 2.78 \\
\hline 27E004 & Charlton & 40.54 & 43.76 & 3.22 \\
\hline 32L015 & Wayne & 8.22 & 13.48 & 5.26 \\
\hline $32 \mathrm{R} 002$ & Bulloch & 18.01 & 22.35 & 4.34 \\
\hline 33Е007 & Camden & 15.26 & 27.10 & 11.84 \\
\hline 33E027 & Camden & 23.51 & 34.11 & 10.60 \\
\hline 33G008 & Glynn & 18.72 & 23.16 & 4.44 \\
\hline $33 \mathrm{H} 120$ & Glynn & -2.99 & 3.08 & 6.07 \\
\hline $33 \mathrm{H} 130$ & Glynn & -4.59 & 2.18 & 6.77 \\
\hline $33 \mathrm{H} 133$ & Glynn & -0.89 & 3.77 & 4.66 \\
\hline $33 \mathrm{H} 177$ & Glynn & 21.16 & 28.24 & 7.08 \\
\hline $33 \mathrm{H} 207$ & Glynn & 4.16 & 8.09 & 3.93 \\
\hline 33M004 & Long & 0.40 & 6.36 & 5.96 \\
\hline $34 \mathrm{G} 002$ & Glynn & 17.62 & 22.37 & 4.75 \\
\hline 34G009 & Glynn & 35.50 & 38.73 & 3.23 \\
\hline $34 \mathrm{G} 016$ & Glynn & 23.69 & 28.28 & 4.59 \\
\hline $34 \mathrm{G} 020$ & Glynn & 26.18 & 30.10 & 3.92 \\
\hline $34 \mathrm{H} 112$ & Glynn & 6.62 & 12.85 & 6.23 \\
\hline $34 \mathrm{H} 117$ & Glynn & 4.54 & 10.47 & 5.93 \\
\hline $34 \mathrm{H} 125$ & Glynn & 4.45 & 12.38 & 7.93 \\
\hline $34 \mathrm{H} 344$ & Glynn & 3.25 & 6.22 & 2.97 \\
\hline $34 \mathrm{H} 355$ & Glynn & 3.88 & 8.46 & 4.58 \\
\hline $34 \mathrm{H} 371$ & Glynn & 10.83 & 15.54 & 4.71 \\
\hline $34 \mathrm{H} 373$ & Glynn & -1.07 & 3.98 & 5.05 \\
\hline $34 \mathrm{H} 393$ & Glynn & 8.53 & 14.56 & 6.03 \\
\hline $34 \mathrm{H} 469$ & Glynn & 5.56 & 6.61 & 1.05 \\
\hline $35 \mathrm{~T} 003$ & Effingham & 31.40 & 2.11 & -29.29 \\
\hline 36Q008 & Chatham & -90.48 & -82.07 & 8.41 \\
\hline 36Q020 & Chatham & -42.17 & -38.20 & 3.97 \\
\hline
\end{tabular}


Table 2. Water-level measurements taken during 2000 and 2004 and observed water-level change during the same period.-Continued

[NAVD 88, North American Vertical Datum of 1988; see fig. 2-1 for well locations]

\begin{tabular}{|c|c|c|c|c|}
\hline \multirow{2}{*}{$\begin{array}{c}\text { Well } \\
\text { identifier }\end{array}$} & \multirow[t]{2}{*}{ County } & \multicolumn{2}{|c|}{$\begin{array}{c}\text { Water level, } \\
\text { in feet above or below NAVD } 88\end{array}$} & \multirow{2}{*}{$\begin{array}{l}\text { Water-level change } \\
\text { from } 2000 \text { to } 2004 \text {, } \\
\text { in feet }\end{array}$} \\
\hline & & 2000 & 2004 & \\
\hline \multicolumn{5}{|c|}{ Upper water-bearing zone of Upper Floridan aquifer (UWBZUFA)—Continued } \\
\hline $37 \mathrm{P} 114$ & Chatham & -46.02 & -43.63 & 2.39 \\
\hline 37Q016 & Chatham & -82.22 & -76.98 & 5.24 \\
\hline 37Q185 & Chatham & -99.22 & -95.22 & 4.00 \\
\hline 38Q002 & Chatham & -30.36 & -28.11 & 2.25 \\
\hline \multirow[t]{2}{*}{ 39Q003 } & Chatham & -27.90 & -25.21 & 2.69 \\
\hline & & & UWBZUFA mean & 4.03 \\
\hline \multicolumn{5}{|c|}{ Lower water-bearing zone of Upper Floridan aquifer (LWBZUFA) } \\
\hline $33 \mathrm{H} 127$ & Glynn & 0.60 & 7.85 & 7.25 \\
\hline $33 \mathrm{H} 154$ & Glynn & -27.58 & -17.85 & 9.73 \\
\hline $34 \mathrm{H} 334$ & Glynn & 7.51 & 12.42 & 4.91 \\
\hline \multirow[t]{2}{*}{$34 \mathrm{H} 403$} & Glynn & 10.12 & 16.27 & 6.15 \\
\hline & & & LWBZUFA mean & 7.01 \\
\hline \multicolumn{5}{|c|}{ Lower Floridan aquifer (LFA) } \\
\hline 33D073 & Camden & 3.58 & 30.67 & 27.09 \\
\hline $33 \mathrm{H} 188$ & Glynn & 12.46 & 20.14 & 7.68 \\
\hline $33 \mathrm{H} 206$ & Glynn & 8.40 & 14.01 & 5.61 \\
\hline 33J044 & Glynn & 13.89 & 19.13 & 5.24 \\
\hline 34H391 & Glynn & 9.18 & 11.87 & 2.69 \\
\hline $34 \mathrm{H} 436$ & Glynn & 11.70 & 15.80 & 4.10 \\
\hline 35P109 & Bryan & -21.83 & -18.87 & 2.96 \\
\hline \multirow[t]{2}{*}{ 39Q024 } & Chatham & -31.67 & -29.94 & 1.73 \\
\hline & & & LFA mean & 7.14 \\
\hline
\end{tabular}


Table 3. Water-level measurements taken during 2000 and 2004 and observed water-level change during the same period in the Brunswick/ Glynn County area.

[NAVD 88, North American Vertical Datum of 1988; see fig. 2-1 for well locations]

\begin{tabular}{|c|c|c|c|}
\hline \multirow{2}{*}{$\begin{array}{l}\text { Well } \\
\text { identifier }\end{array}$} & \multicolumn{2}{|c|}{$\begin{array}{c}\text { Water level, in feet } \\
\text { above or below NAVD } 88\end{array}$} & \multirow{2}{*}{$\begin{array}{l}\text { Water-level change } \\
\text { from } 2000 \text { to } 2004 \text {, } \\
\text { in feet }\end{array}$} \\
\hline & 2000 & 2004 & \\
\hline \multicolumn{4}{|c|}{ Upper Brunswick aquifer (UBA) } \\
\hline 33G028 & 16.75 & 21.31 & 4.56 \\
\hline \multirow[t]{2}{*}{$34 \mathrm{H} 437$} & 5.88 & 8.92 & 3.04 \\
\hline & & Mean & 3.80 \\
\hline \multicolumn{4}{|c|}{ Upper water-bearing zone of Upper Floridan aquifer (UWBZUFA) } \\
\hline 33G008 & 18.72 & 23.16 & 4.44 \\
\hline $33 \mathrm{H} 120$ & -2.99 & 3.08 & 6.07 \\
\hline $33 \mathrm{H} 130$ & -4.59 & 2.18 & 6.77 \\
\hline $33 \mathrm{H} 133$ & -0.89 & 3.77 & 4.66 \\
\hline $33 \mathrm{H} 177$ & 21.16 & 28.24 & 7.08 \\
\hline $33 \mathrm{H} 207$ & 4.16 & 8.09 & 3.93 \\
\hline $34 \mathrm{G} 002$ & 17.62 & 22.37 & 4.75 \\
\hline $34 \mathrm{G} 009$ & 35.50 & 38.73 & 3.23 \\
\hline $34 \mathrm{G} 016$ & 23.70 & 28.28 & 4.58 \\
\hline $34 \mathrm{G} 020$ & 26.18 & 30.10 & 3.92 \\
\hline $34 \mathrm{H} 112$ & 6.62 & 12.85 & 6.23 \\
\hline 34H117 & 4.54 & 10.47 & 5.93 \\
\hline $34 \mathrm{H} 125$ & 4.45 & 12.38 & 7.93 \\
\hline $34 \mathrm{H} 344$ & 3.25 & 6.22 & 2.97 \\
\hline $34 \mathrm{H} 355$ & 3.88 & 8.46 & 4.58 \\
\hline $34 \mathrm{H} 371$ & 10.80 & 15.54 & 4.74 \\
\hline $34 \mathrm{H} 373$ & -1.07 & 3.98 & 5.05 \\
\hline $34 \mathrm{H} 393$ & 8.53 & 14.56 & 6.03 \\
\hline \multirow[t]{2}{*}{$34 \mathrm{H} 469$} & 5.56 & 6.61 & 1.05 \\
\hline & & Mean & 4.94 \\
\hline \multicolumn{4}{|c|}{ Lower water-bearing zone of Upper Floridan aquifer (LWBZUFA) } \\
\hline $33 \mathrm{H} 127$ & 0.60 & 7.85 & 7.25 \\
\hline $33 \mathrm{H} 154$ & -27.58 & -17.85 & 9.73 \\
\hline $34 \mathrm{H} 334$ & 7.51 & 12.42 & 4.91 \\
\hline \multirow[t]{2}{*}{$34 \mathrm{H} 403$} & 10.12 & 16.27 & 6.15 \\
\hline & & Mean & 7.01 \\
\hline \multicolumn{4}{|c|}{ Lower Floridan aquifer (LFA) } \\
\hline $33 \mathrm{H} 188$ & 12.46 & 20.14 & 7.68 \\
\hline $33 \mathrm{H} 206$ & 8.40 & 14.01 & 5.61 \\
\hline 33J044 & 13.89 & 19.13 & 5.24 \\
\hline $34 \mathrm{H} 391$ & 9.18 & 11.87 & 2.69 \\
\hline \multirow[t]{2}{*}{$34 \mathrm{H} 436$} & 11.70 & 15.80 & 4.10 \\
\hline & & Mean & 5.06 \\
\hline
\end{tabular}




\section{Simulation of Steady-State Ground water Flow, 2000-04}

The digital groundwater-flow model originally developed to simulate regional confined groundwater flow in the coastal area of Georgia, Florida, South Carolina, and adjacent offshore areas (Payne and others, 2005) was revised to evaluate hydraulic gradients in the Brunswick/ Glynn County area. The original model was developed using MODFLOW-2000 (Harbaugh and others, 2000), and simulated steady-state flow for predevelopment, 1980, and 2000 conditions. Details of the original model development are provided in Payne and others (2005) and are briefly described in the following sections. Steady-state simulations were also considered reasonable for the revised model because of the focus on changes in mean-annual pumping for 2000 and 2004. According to Payne and others (2005), the original model was tested for transient response and the results indicated that relatively extreme changes in stress were required to affect a transient response. Locally in the Brunswick/Glynn County area, groundwater flow in the Upper Floridan aquifer is considered to be in equilibrium where recharge to the aquifer is balanced by natural discharge and pumping (Krause and Randolph, 1989). In addition, calculations comparing the estimated rate at which water derived from storage for the period from 1945 to 1986 with a mean pumping value of $70.8 \mathrm{Mgal} / \mathrm{d}$ from the Upper Floridan aquifer over the 42-year period indicated that less than 0.1 percent of the 1986 pumpage was derived from storage (L.E. Jones, U.S. Geological Survey, written commun., November 2014). Therefore, the assumption of nearly steady-state conditions for the Upper Floridan aquifer in Glynn County because of the negligible contributions of water from aquifer storage is reasonable.

\section{Revision of Groundwater-Flow Model}

To develop the revised model, the original model was modified in terms of grid size (discretization), model layers, hydraulic properties, boundary conditions, use of pumping rates for 2004, and recalibration to observed water levels. The original model focused on the Floridan aquifer system at a regional scale with reduced grid spacing in the Savannah and Brunswick areas for further evaluation, whereas the addition of layers/zones in the revised model based on the local hydrogeology improve the simulation of the steep hydraulic gradients that have formed in the Brunswick area as a result of pumping. These modifications allowed a more accurate computed solution of head in the Brunswick/Glynn County area along with head gradients and leakage rates that were not possible with the original model.

\section{Discretization}

The original model encompasses $42,155 \mathrm{mi}^{2}$ and consists of 119 rows and 108 columns, with cell sizes ranging from $4,000 \times 5,000 \mathrm{ft}\left(0.7 \mathrm{mi}^{2}\right)$ to $16,500 \times 16,500 \mathrm{ft}\left(9.8 \mathrm{mi}^{2}\right)$. Because of the focus on the Brunswick/Glynn County area in the current study, a refined grid spacing was chosen to enable more accurate simulation of the steep head gradients near cones of depression. Graphical grid-generation tools from the graphical user interface Argus ONE enabled visual adjustment of grid position and density. The revised grid configuration has the same orientation as the original model, but the number of rows and columns has been increased to 424 and 452, respectively (fig. 7). The variable cell sizes range from $500 \times 500 \mathrm{ft}$ $\left(0.009 \mathrm{mi}^{2}\right)$ near downtown Brunswick, to $5,000 \times 5,000 \mathrm{ft}$ $\left(0.90 \mathrm{mi}^{2}\right)$ near the edges of the model area. The irregular grid configuration results in elongated cells along the outer margins of the model having aspect ratios as large as 10:1 between row and column spacings. This large aspect ratio is approaching the recommended limit, above which numerical errors could occur (de Marsily, 1986, p. 351).

\section{Model Layers}

Layers used in the original model to vertically discretize groundwater flow were modified in the revised model to simulate the local hydrogeology in the Brunswick/Glynn County area. The original model contained layers for the surficial aquifer system (layer 1), Brunswick aquifer system (layer 3), UFA (layer 5), and LFA (layer 7), and for intervening confining units between these aquifers (layers 2,4 , and 6). The revised model contains four additional layers to detail the vertical representation of the Brunswick aquifer system and Upper Floridan aquifer. As shown in figure 8 and table 4, the Brunswick aquifer system has been subdivided into the upper Brunswick aquifer (layer 3) and lower Brunswick aquifer (layer 5) with an intervening confining unit (layer 4), and the UFA has been subdivided into the UWBZ (layer 7) and the LWBZ (layer 9) with an intervening confining unit (layer 8).

Published data were used to assign altitudes to the top of each unit represented in the original model. Published literature (Brooks and others, 1985; Charm and others, 1969; Clarke and others, 1990; Hathaway and others, 1981; Kellam and Gorday, 1990; Miller, 1986; Scholle, 1979; Steele and McDowell, 1998) provided information to construct contour maps showing the altitude of the top of each layer and this information was modified using well information collected as part of the Coastal Sound Science Initiative (Falls and others, 2001; Foyle and others, 2001). In the Brunswick/Glynn County area, the UWBZ and LWBZ (model layers 7 and 9) were extended to include all of Glynn County and neighboring Camden County. Beyond these 


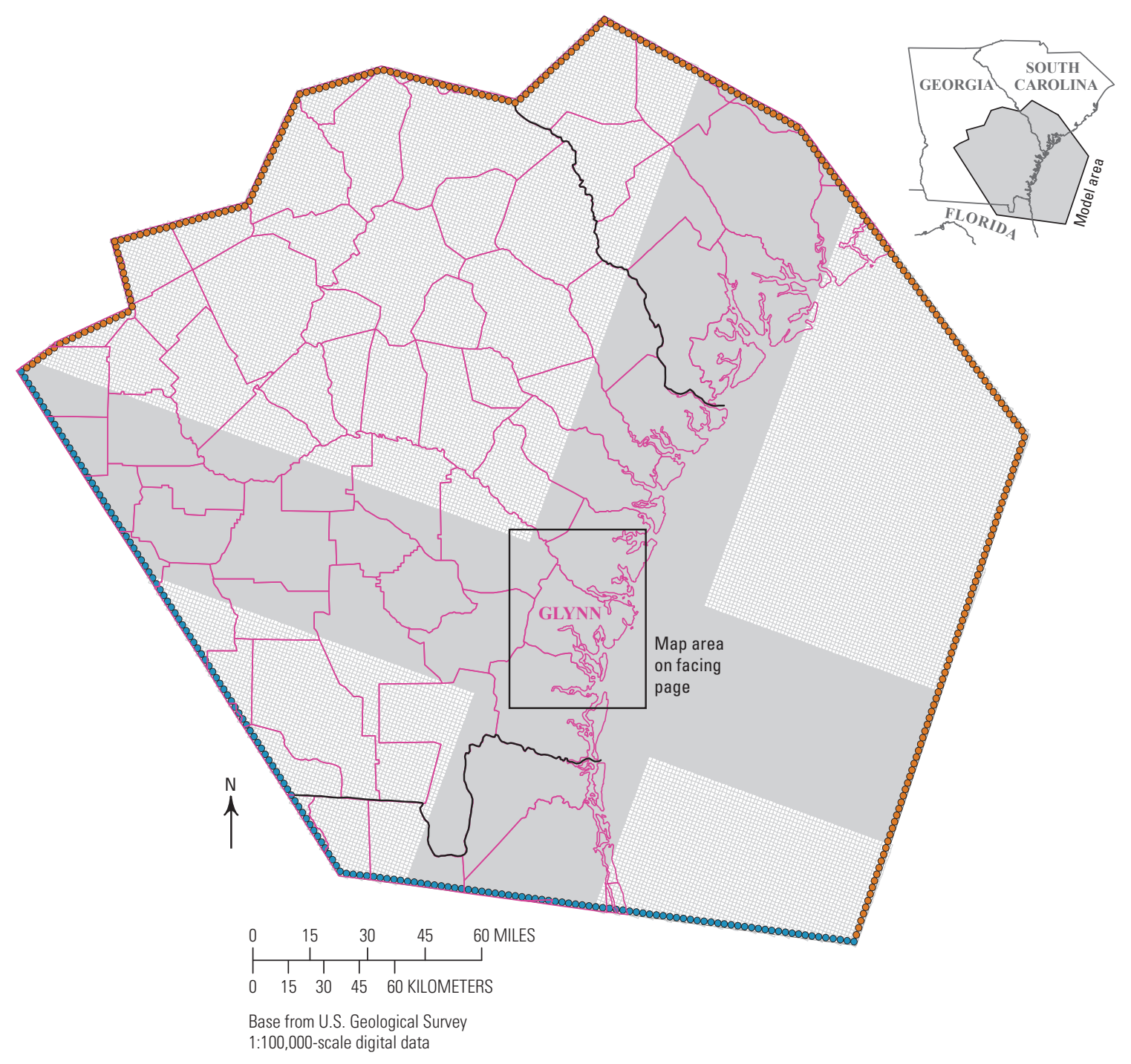

\section{EXPLANATION}

Area of dense model grid-Grid spacing progressively increases by a factor of 1.5 from a minimum of 500 feet to a maximum of 5,000 feet

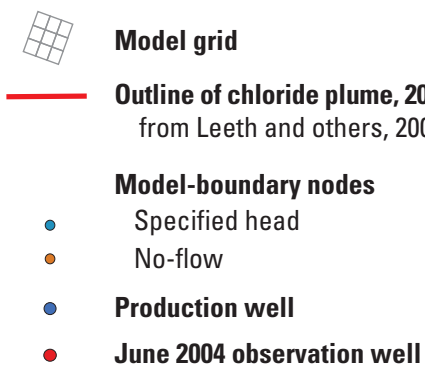

Figure 7. Revised model grid, major production wells, observation wells used during June of 2004, and outline of the 2004 chloride plume for the Upper Floridan aquifer in the Brunswick area. 

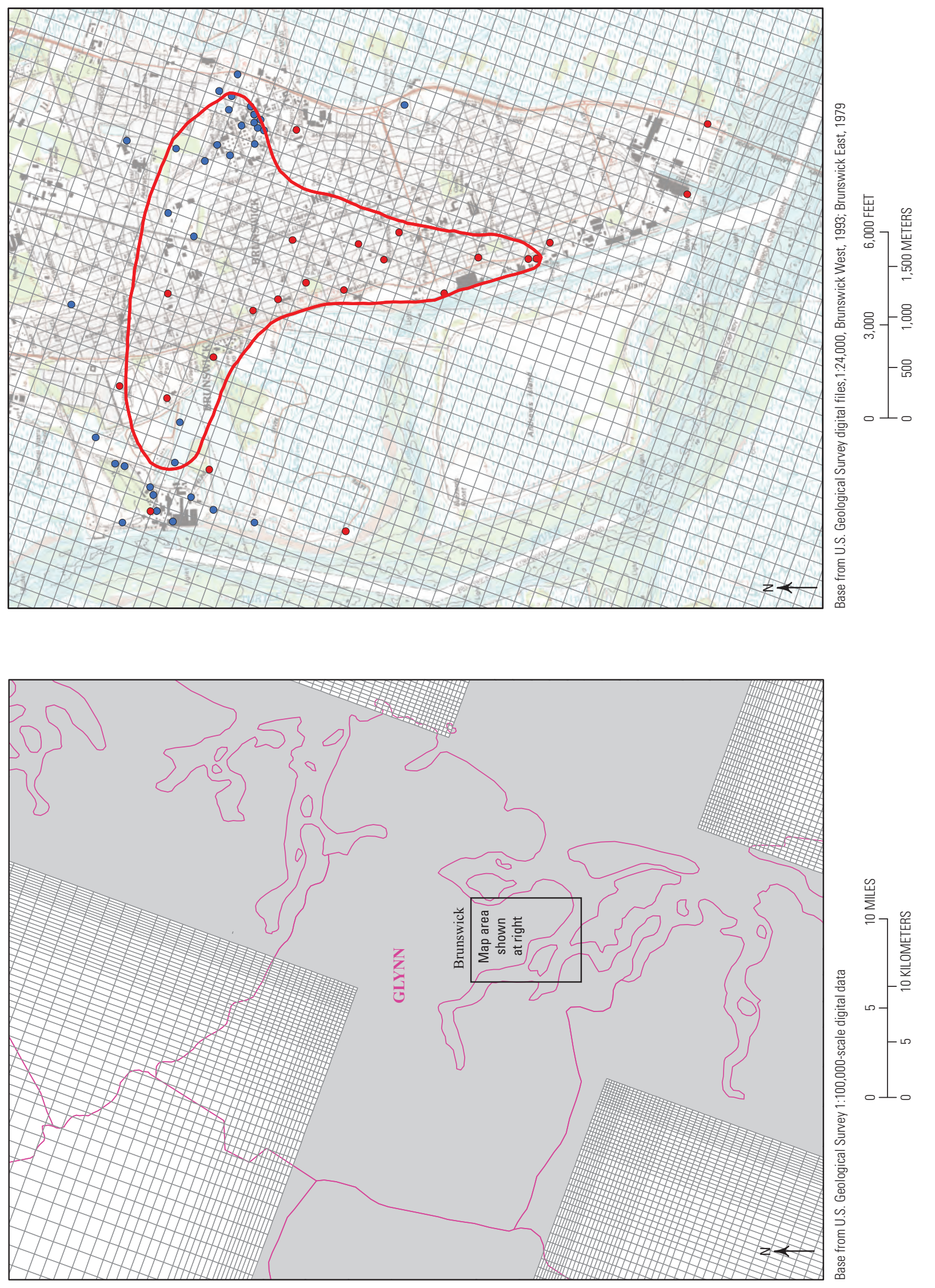

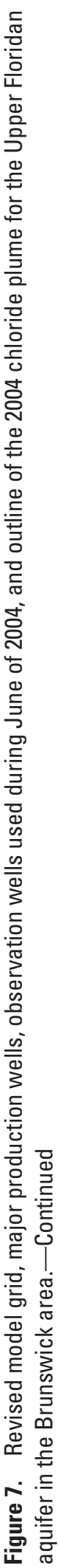




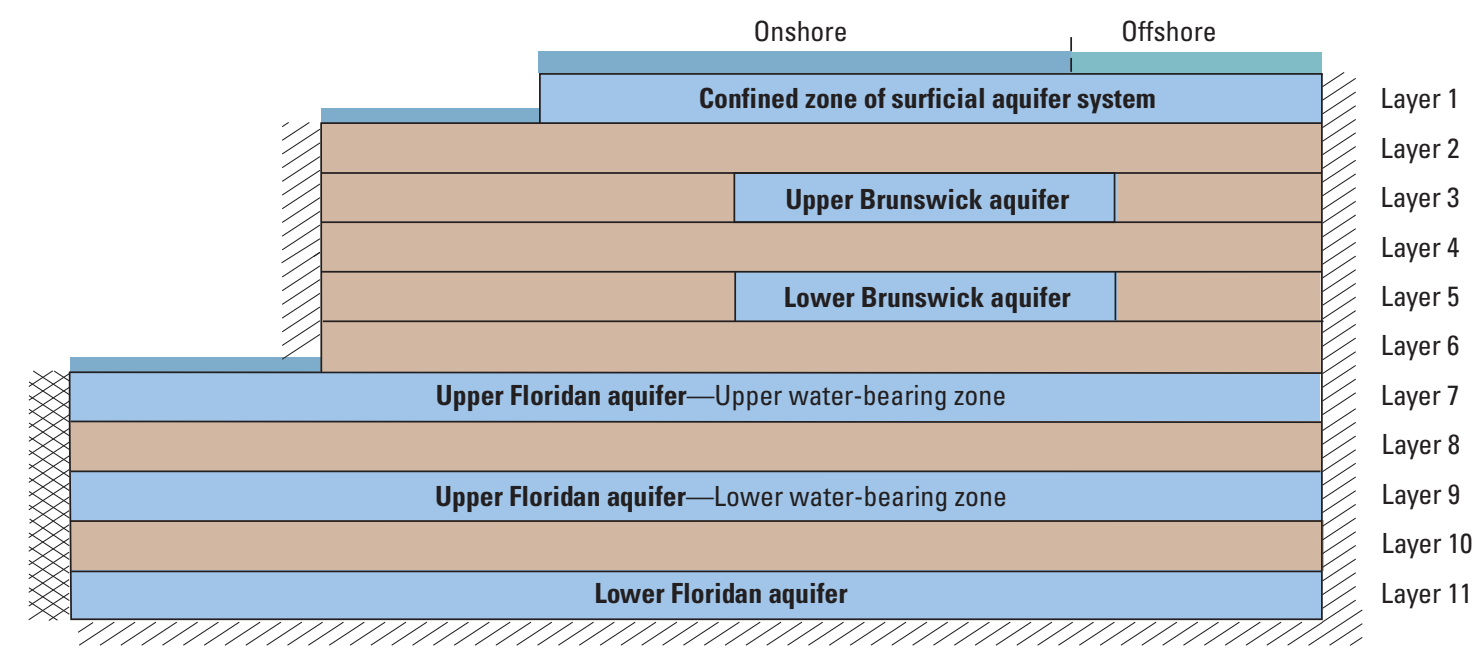

EXPLANATION

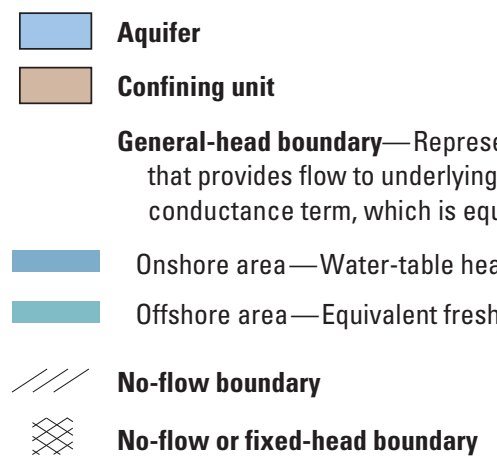

Figure 8. Schematic diagram showing model layers and boundary conditions.

areas, the UFA was considered to be one unit that includes model layers 7 through 9 . In addition, where the UWBZ and LWBZ are absent, a minimal thickness of $1 \mathrm{ft}$ was assigned to fulfill the requirements of MODFLOW-2000 (Harbaugh and others, 2000) for a continuous model layer to exist across the entire model area, and that layer of minimal thickness was assigned the hydraulic conductivity of the overlying layer. A schematic diagram (fig. 8) and hydrogeologic sections (fig. 9) along the approximate strike and dip of geologic formations illustrate how model layer thicknesses vary over the model domain. The Brunswick aquifer system (layers 3-5) varies in thickness, ranging from 300 to $400 \mathrm{ft}$ along the Brunswick peninsula and thins to the north toward the Savannah area. The combined thickness of the UWBZ and LWBZ of the UFA and intervening confining unit (layers 7-9) reaches about $400 \mathrm{ft}$ near the Brunswick peninsula. In the Glynn/Camden County area, the thickness of the UWBZ (layer 7) of the UFA is highly variable ranging from 26 to $266 \mathrm{ft}$ with an average thickness of $139 \mathrm{ft}$. The semiconfining unit (layer 8) ranges in thickness from 34 to $265 \mathrm{ft}$ with an average thickness of $85 \mathrm{ft}$. The thickness of the LWBZ (layer 9) of the UFA is less variable ranging from 86 to $193 \mathrm{ft}$ with an average thickness of $163 \mathrm{ft}$. The UFA thins toward the Gulf Trough and thickens to $800 \mathrm{ft}$ beneath the Atlantic Ocean. The hydrogeologic section along the Georgia coast $\left(B-B^{\prime}\right)$ illustrates how hydrogeologic units generally thicken toward the Southeast Georgia Embayment where the LFA reaches thicknesses greater than 2,000 ft (fig. 9). 


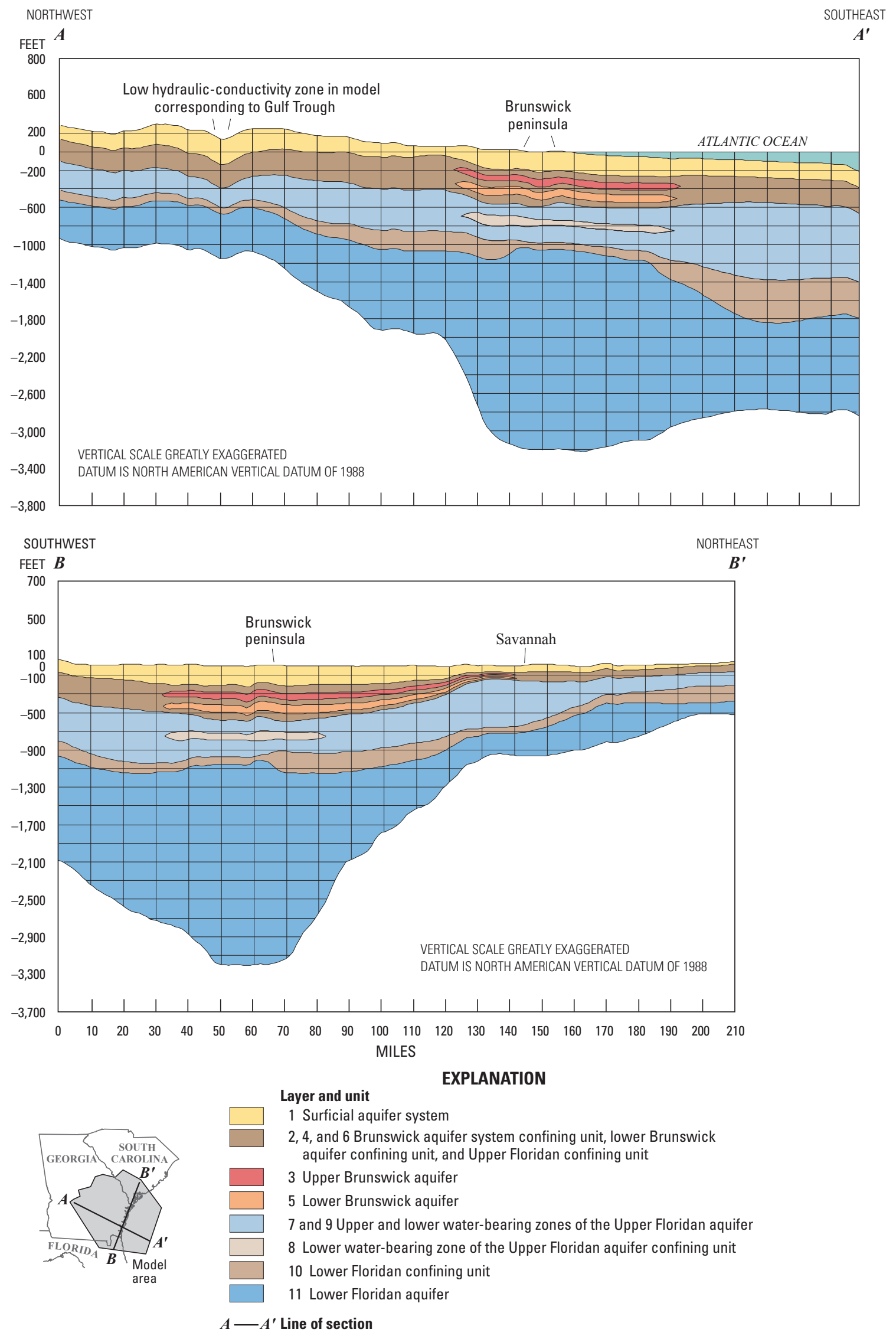

Figure 9. Hydrogeologic sections showing vertical discretization of hydrogeologic units simulated by the revised model. 
Table 4. Horizontal and vertical hydraulic conductivity values assigned to hydraulic property zones for the original (Payne and others, 2005) and revised groundwater-flow models.

[-, not applicable; UWBZ, upper water-bearing zone; LWBZ, lower water-bearing zone; Kh, horizontal hydraulic conductivity; Kv, vertical hydraulic conductivity; ft/day, foot per day]

\begin{tabular}{|c|c|c|c|}
\hline \multirow[b]{2}{*}{ Unit } & \multirow[b]{2}{*}{ Layer } & \multicolumn{2}{|c|}{ Payne and others (2005) } \\
\hline & & $\begin{array}{l}\text { Hydraulic } \\
\text { property } \\
\text { zone }\end{array}$ & $\begin{array}{l}\text { Hydraulic conductivity, } \\
\text { Kh and } K v, \\
\text { in feet per day }\end{array}$ \\
\hline Surficial aquifer & 1 & - & 70 \\
\hline \multirow[t]{5}{*}{ Confining unit } & 2 & $\mathrm{C} 1$ & 0.00017 \\
\hline & & $\mathrm{C} 2$ & 0.20000 \\
\hline & & $\mathrm{C} 3$ & 0.00001 \\
\hline & & $\mathrm{C} 4$ & 0.00010 \\
\hline & & $\mathrm{C} 5$ & 0.00010 \\
\hline \multirow{15}{*}{$\begin{array}{l}\text { Brunswick } \\
\text { aquifer system }\end{array}$} & 3 & B1 & 50 \\
\hline & & $\mathrm{C} 1$ & 0.00017 \\
\hline & & $\mathrm{C} 2$ & 0.20000 \\
\hline & & $\mathrm{C} 3$ & 0.00001 \\
\hline & & $\mathrm{C} 4$ & 0.00010 \\
\hline & & - & - \\
\hline & & - & - \\
\hline & & - & - \\
\hline & & - & - \\
\hline & & - & - \\
\hline & & - & - \\
\hline & & - & - \\
\hline & & - & - \\
\hline & & - & - \\
\hline & & - & - \\
\hline \multirow[t]{5}{*}{ Confining unit } & 4 & $\mathrm{C} 1$ & 0.00017 \\
\hline & & $\mathrm{C} 2$ & 0.20000 \\
\hline & & $\mathrm{C} 3$ & 0.00001 \\
\hline & & $\mathrm{C} 4$ & 0.00010 \\
\hline & & $\mathrm{C} 5$ & 0.00010 \\
\hline \multirow{17}{*}{$\begin{array}{l}\text { Upper Floridan } \\
\text { aquifer }\end{array}$} & 5 & $\mathrm{~F} 1$ & 34 \\
\hline & & $\mathrm{F} 2$ & 2 \\
\hline & & $\mathrm{F} 3$ & 100 \\
\hline & & $\mathrm{F} 4$ & 70 \\
\hline & & F5 & 394 \\
\hline & & F6 & 2,819 \\
\hline & & F7 & 150 \\
\hline & & F8 & 2,727 \\
\hline & & F9 & 100 \\
\hline & & F10 & 56 \\
\hline & & F11 & 94 \\
\hline & & F12 & 25 \\
\hline & & - & - \\
\hline & & - & - \\
\hline & & - & - \\
\hline & & - & - \\
\hline & & - & - \\
\hline
\end{tabular}

\begin{tabular}{|c|c|c|c|}
\hline \multirow[b]{2}{*}{ Unit } & \multirow[b]{2}{*}{ Layer } & \multicolumn{2}{|c|}{ Revised model } \\
\hline & & $\begin{array}{l}\text { Hydraulic } \\
\text { property } \\
\text { zone (fig. 9) }\end{array}$ & $\begin{array}{c}\text { Hydraulic conductivity, } \\
K h \text { and } K v, \\
\text { in feet per day }\end{array}$ \\
\hline Surficial aquifer & 1 & - & 105 \\
\hline \multirow{5}{*}{ Confining unit } & 2 & $\mathrm{C} 1$ & 0.00257 \\
\hline & & $\mathrm{C} 2$ & 0.20000 \\
\hline & & $\mathrm{C} 3$ & 0.00001 \\
\hline & & $\mathrm{C} 4$ & 0.00010 \\
\hline & & $\mathrm{C} 5$ & 0.00010 \\
\hline \multirow{5}{*}{$\begin{array}{l}\text { Upper Brunswick } \\
\text { aquifer }\end{array}$} & 3 & B1 & 10 \\
\hline & & $\mathrm{C} 1$ & 0.00257 \\
\hline & & $\mathrm{C} 2$ & 0.20000 \\
\hline & & $\mathrm{C} 3$ & 0.00001 \\
\hline & & $\mathrm{C} 4$ & 0.00010 \\
\hline \multirow[t]{5}{*}{ Confining unit } & 4 & B1 & 0.02 \\
\hline & & $\mathrm{C} 1$ & 0.00257 \\
\hline & & $\mathrm{C} 2$ & 0.20000 \\
\hline & & $\mathrm{C} 3$ & 0.00001 \\
\hline & & $\mathrm{C} 4$ & 0.00010 \\
\hline \multirow{5}{*}{$\begin{array}{l}\text { Lower Brunswick } \\
\text { aquifer }\end{array}$} & 5 & B1 & 20 \\
\hline & & $\mathrm{C} 1$ & 0.00257 \\
\hline & & $\mathrm{C} 2$ & 0.20000 \\
\hline & & $\mathrm{C} 3$ & 0.00001 \\
\hline & & $\mathrm{C} 4$ & 0.00010 \\
\hline \multirow[t]{5}{*}{ Confining unit } & 6 & $\mathrm{C} 1$ & 0.00257 \\
\hline & & $\mathrm{C} 2$ & 0.20000 \\
\hline & & $\mathrm{C} 3$ & 0.00001 \\
\hline & & $\mathrm{C} 4$ & 0.00010 \\
\hline & & $\mathrm{C} 5$ & 0.00010 \\
\hline \multirow{17}{*}{$\begin{array}{l}\text { UWBZ of Upper } \\
\text { Floridan aquifer }\end{array}$} & 7 & $\mathrm{~F} 1$ & 40 \\
\hline & & $\mathrm{F} 2$ & 20 \\
\hline & & F3 & 150 \\
\hline & & F4 & 65 \\
\hline & & F5 & 225 \\
\hline & & F6 & 3,415 \\
\hline & & F7 & 750 \\
\hline & & F8 & 3,000 \\
\hline & & F9 & 150 \\
\hline & & F10 & 84 \\
\hline & & F11 & 126 \\
\hline & & F12 & 25 \\
\hline & & F13 & 300 \\
\hline & & F14 & 240 \\
\hline & & F15 & 200 \\
\hline & & $\mathrm{F} 16^{\mathrm{a}}$ & 76 \\
\hline & & $\mathrm{F} 17^{\mathrm{b}}$ & 398 \\
\hline
\end{tabular}


Table 4. Horizontal and vertical hydraulic conductivity values assigned to hydraulic property zones for the original (Payne and others, 2005) and revised groundwater-flow models.-Continued

[-, not applicable; UWBZ, upper water-bearing zone; LWBZ, lower water-bearing zone; Kh, horizontal hydraulic conductivity; Kv, vertical hydraulic conductivity; ft/day, foot per day]

\begin{tabular}{|c|c|c|c|}
\hline \multirow[b]{2}{*}{ Unit } & \multirow[b]{2}{*}{ Layer } & \multicolumn{2}{|c|}{ Payne and others (2005) } \\
\hline & & $\begin{array}{l}\text { Hydraulic } \\
\text { property } \\
\text { zone }\end{array}$ & $\begin{array}{c}\text { Hydraulic conductivity } \\
\text { Kh and Kv, } \\
\text { in feet per day }\end{array}$ \\
\hline \multirow[t]{17}{*}{ Confining unit } & & - & - \\
\hline & & - & - \\
\hline & & - & - \\
\hline & & - & - \\
\hline & & - & - \\
\hline & & - & - \\
\hline & & - & - \\
\hline & & - & - \\
\hline & & - & - \\
\hline & & - & - \\
\hline & & - & - \\
\hline & & - & - \\
\hline & & - & - \\
\hline & & - & - \\
\hline & & - & - \\
\hline & & - & - \\
\hline & & - & - \\
\hline \multirow{17}{*}{$\begin{array}{l}\text { LWBZ of Upper } \\
\text { Floridan aquifer }\end{array}$} & & - & - \\
\hline & & - & - \\
\hline & & - & - \\
\hline & & - & - \\
\hline & & - & - \\
\hline & & - & - \\
\hline & & - & - \\
\hline & & - & - \\
\hline & & - & - \\
\hline & & - & - \\
\hline & & - & - \\
\hline & & - & - \\
\hline & & - & - \\
\hline & & - & - \\
\hline & & - & - \\
\hline & & - & - \\
\hline & & - & - \\
\hline \multirow[t]{3}{*}{ Confining unit } & 6 & - & 0.02000 \\
\hline & & - & - \\
\hline & & - & - \\
\hline \multirow{3}{*}{$\begin{array}{l}\text { Lower Floridan } \\
\text { aquifer }\end{array}$} & 7 & - & 10 \\
\hline & & - & - \\
\hline & & - & - \\
\hline
\end{tabular}

\begin{tabular}{|c|c|c|c|}
\hline \multirow[b]{2}{*}{ Unit } & \multirow[b]{2}{*}{ Layer } & \multicolumn{2}{|c|}{ Revised model } \\
\hline & & $\begin{array}{l}\text { Hydraulic } \\
\text { property } \\
\text { zone (fig. 9) }\end{array}$ & $\begin{array}{c}\text { Hydraulic conductivity, } \\
K h \text { and } K v, \\
\text { in feet per day }\end{array}$ \\
\hline \multirow[t]{17}{*}{ Confining unit } & 8 & $\mathrm{~F} 1$ & 40 \\
\hline & & $\mathrm{F} 2$ & 20 \\
\hline & & $\mathrm{F} 3$ & 150 \\
\hline & & F4 & 65 \\
\hline & & F5 & 225 \\
\hline & & F6 & 3,415 \\
\hline & & F7 & 0.2 \\
\hline & & F8 & 0.2 \\
\hline & & F9 & 150 \\
\hline & & F10 & 84 \\
\hline & & F11 & 126 \\
\hline & & F12 & 25 \\
\hline & & F13 & 0.2 \\
\hline & & F14 & 0.2 \\
\hline & & F15 & 0.2 \\
\hline & & $\mathrm{F} 16^{\mathrm{a}}$ & 76 \\
\hline & & $\mathrm{F} 17^{\mathrm{b}}$ & 398 \\
\hline \multirow{17}{*}{$\begin{array}{l}\text { LWBZ of Upper } \\
\text { Floridan aquifer }\end{array}$} & 9 & $\mathrm{~F} 1$ & 40 \\
\hline & & $\mathrm{F} 2$ & 20 \\
\hline & & F3 & 150 \\
\hline & & F4 & 65 \\
\hline & & F5 & 225 \\
\hline & & F6 & 3,415 \\
\hline & & F7 & 750 \\
\hline & & F8 & 3,000 \\
\hline & & F9 & 150 \\
\hline & & F10 & 84 \\
\hline & & F11 & 126 \\
\hline & & F12 & 25 \\
\hline & & F13 & 270 \\
\hline & & F14 & 200 \\
\hline & & F15 & 125 \\
\hline & & $\mathrm{F} 16^{\mathrm{a}}$ & 76 \\
\hline & & $\mathrm{F} 17^{\mathrm{b}}$ & 398 \\
\hline \multirow[t]{3}{*}{ Confining unit } & 10 & LFC1 & 0.02000 \\
\hline & & $\mathrm{LFC}^{\mathrm{a}}$ & 0.20000 \\
\hline & & $\mathrm{LFC}^{\mathrm{b}}$ & 10.00000 \\
\hline \multirow{3}{*}{$\begin{array}{l}\text { Lower Floridan } \\
\text { aquifer }\end{array}$} & 11 & LF1 & 10 \\
\hline & & $\mathrm{LF}^{\mathrm{a}}$ & 100 \\
\hline & & $\mathrm{LF}^{\mathrm{b}}{ }^{\mathrm{b}}$ & 15.8 \\
\hline
\end{tabular}

${ }^{\mathrm{a}}$ Clarke and others (2010); $\mathrm{LFC} 2 \mathrm{Kh}=0.2 \mathrm{ft} / \mathrm{day}, \mathrm{Kv}=0.02 \mathrm{ft} / \mathrm{day}$

${ }^{\mathrm{b}}$ Clarke and others (2011); LFC3 Kv=0.2 ft/day, LF3 Kh=15.8 ft/day, Kv=1.6 ft/day 


\section{Hydraulic Properties}

In the Brunswick/Glynn County area, the original model contained designated homogeneous and isotropic hydraulic property zones for all aquifers and confining units except the UFA, which consisted of two zones within Glynn County. For the revised model, additional zones were designated on the basis of available aquifer-test and geologic data (fig. 10; table 4). These data include the vertical $\left(\mathrm{K}_{\mathrm{v}}\right)$ and horizontal $\left(\mathrm{K}_{\mathrm{h}}\right)$ hydraulic conductivity for all model layers, which were used as initial estimates in the revised model prior to any model adjustments (Clarke and others, 2004). Additional zones were created (F13, F14, and F15) within the UFA (layers 7-9) near the Brunswick area to further adjust hydraulic properties within zone F7 of the original model. In addition, zones F16 and F17 were added based on aquifer tests in the Floridan aquifer system at Hunter Army Airfield and Fort Stewart (Clarke and others, 2010, 2011). During model calibration, adjustments were made to hydraulic property zones to provide a better match between observed and simulated water levels in the area.

The surficial aquifer (layer 1) was represented by a single zone and assigned a $\mathrm{K}_{\mathrm{h}}$ value of $70 \mathrm{ft} / \mathrm{d}$ throughout the model domain in the original model. This value was increased to $105 \mathrm{ft} / \mathrm{d}$ in the revised model to provide a better match to observed values. The confining unit beneath the surficial aquifer (layer 2), was areally represented in both models by five zones that were assigned $\mathrm{K}_{h}$ values ranging from 0.00001 to $0.2 \mathrm{ft} / \mathrm{d}$ (table 4).

The Brunswick aquifer system was represented differently by the two models. In the original model, the Brunswick aquifer system was simulated by a single layer (3) that was areally subdivided into five zones with $K_{h}$ values ranging from 0.00001 to $50 \mathrm{ft} / \mathrm{d}$. Zone $\mathrm{B} 1$ in the original model corresponded to the approximate extent of the most permeable part of the aquifer system and was assigned a uniform value of $50 \mathrm{ft} / \mathrm{d}$. In the revised model, three layers $(3,4$, and 5$)$ vertically subdivide the Brunswick aquifer system, and zone B1 represents a less permeable part of the aquifer (layer 4) juxtaposed between two more permeable parts (layers 3 and 5), with each layer assigned a uniform value for $\mathrm{K}_{\mathrm{h}}$ and $\mathrm{K}_{\mathrm{v}}$ (table 4). Within each model, the respective assigned values for $\mathrm{C} 1, \mathrm{C} 2, \mathrm{C} 3$, and $\mathrm{C} 4$ did not change between layers (table 4).

The UFA in the original model was represented as a single layer (5) areally subdivided into 12 hydraulic property zones, with $\mathrm{K}_{\mathrm{h}}$ ranging from $2 \mathrm{ft} / \mathrm{d}$ in zone $\mathrm{F} 2$ (in the Gulf Trough region), to 2,819 ft/d in zone F6 (southwest of Glynn County) (fig. 10; table 4). By comparison, a single hydraulic property zone (F7) having a $\mathrm{K}_{\mathrm{h}}$ of $150 \mathrm{ft} / \mathrm{d}$ was used in the original model to represent the UFA in the majority of Glynn County. To enable more detailed simulation of groundwater flow in the Brunswick/Glynn County area than was available using the original model, the UFA in the revised model has been vertically subdivided into the UWBZ (layer 7) and LWBZ (layer 9), separated by a confining unit (layer 8; fig. 8). Each of these new layers contained the same 12 zones used in the original model, plus an additional 3 zones in the Brunswick area to represent variations in $\mathrm{K}_{\mathrm{h}}$ (fig. 10; table 4). The adjusted $\mathrm{K}_{\mathrm{h}}$ of $750 \mathrm{ft} / \mathrm{d}$ for the revised model in hydraulic property zone (F7) multiplied by the average thickness of the UWBZ of $139 \mathrm{ft}$ yields a simulated transmissivity of $104,000 \mathrm{ft}^{2} / \mathrm{d}$. Results from a subregional December 1962 aquifer test using 16 observation wells open to the UWBZ located at distances ranging from 15,400 to $71,400 \mathrm{ft}$ from a pumping well tapping both the UWBZ and LWBZ near Brunswick indicated an average transmissivity value of $88,200 \mathrm{ft}^{2} / \mathrm{d}$ for Glynn County (Jones and Maslia, 1994). Previously reported transmissivity values for the UFA in the Brunswick/Glynn County area were about 150,000 to $200,000 \mathrm{ft}^{2} / \mathrm{d}$, but likely included both the UWBZ and LWBZ (Wait and Gregg, 1973). A localized aquifer test in the Brunswick area performed during July 1985 using 16 observation wells open to the UWBZ and pumping from the UWBZ yielded much lower transmissivity values (Jones and Maslia, 1994). The time-drawdown plots were matched manually to the Hantush-Jacob type curve with an excellent fit in six observation wells located at distances ranging from 700 to $6,300 \mathrm{ft}$ with an average transmissivity value for the UWBZ of $61,000 \mathrm{ft}^{2} / \mathrm{d}$. During December 1986, a localized aquifer test performed in the southern portion of the Brunswick peninsula using two observation wells open to the UWBZ and pumping from a public-supply well open to the UWBZ produced computed transmissivity values of 23,400 and 32,500 ft' $/ \mathrm{d}$, respectively (Jones and Maslia, 1994). Jones and Maslia (1994) reported on another aquifer test performed in April 1990 in which a public-supply well open to the UWBZ located just north of the chloride plume was pumped for 24-hours with a computed transmissivity value from a nearby UWBZ observation well of $57,000 \mathrm{ft}^{2} / \mathrm{d}$. Borehole flowmeter tests (Wait and Gregg, 1973) indicated that the UWBZ contained a higher $\mathrm{K}_{\mathrm{h}}$ than the LWBZ, based on UWBZ contribution of 70 percent of the water from wells tapping both zones.

Zones in the UWBZ were designated as follows:

- Zone F13 $\left(\mathrm{K}_{\mathrm{h}}=300 \mathrm{ft} / \mathrm{d}\right)$ represents an area of intensive groundwater pumping near the northwestern part of the chloride plume and also contains steep hydraulic gradients toward the pumping centers at the Georgia-Pacific Cellulose plant.

- Zone F14 $\left(\mathrm{K}_{\mathrm{h}}=240 \mathrm{ft} / \mathrm{d}\right)$ represents a transitional area between the pumping centers to the north of downtown Brunswick and an area of low hydraulic conductivity at the southern end of the chloride plume to the south.

- Zone F15 $\left(\mathrm{K}_{\mathrm{h}}=200 \mathrm{ft} / \mathrm{d}\right)$ contains steep hydraulic gradients in the potentiometric surface of the UFA that are not attributed to groundwater pumping, thus indicating a decrease in $\mathrm{K}_{\mathrm{h}}$. 


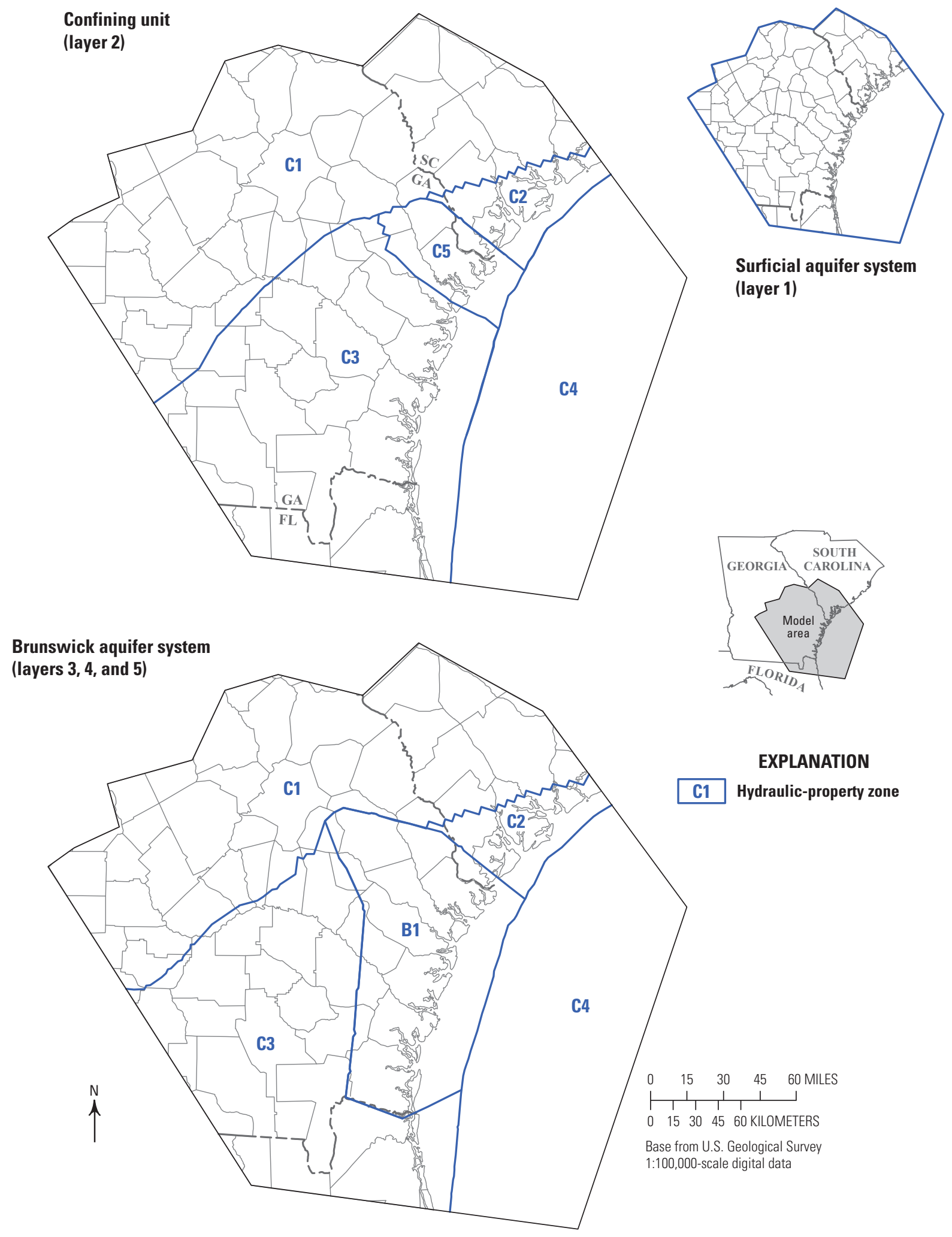

Figure 10. Hydraulic property zones for the regional model (Payne and others, 2005) near Brunswick/Glynn County, Georgia. 

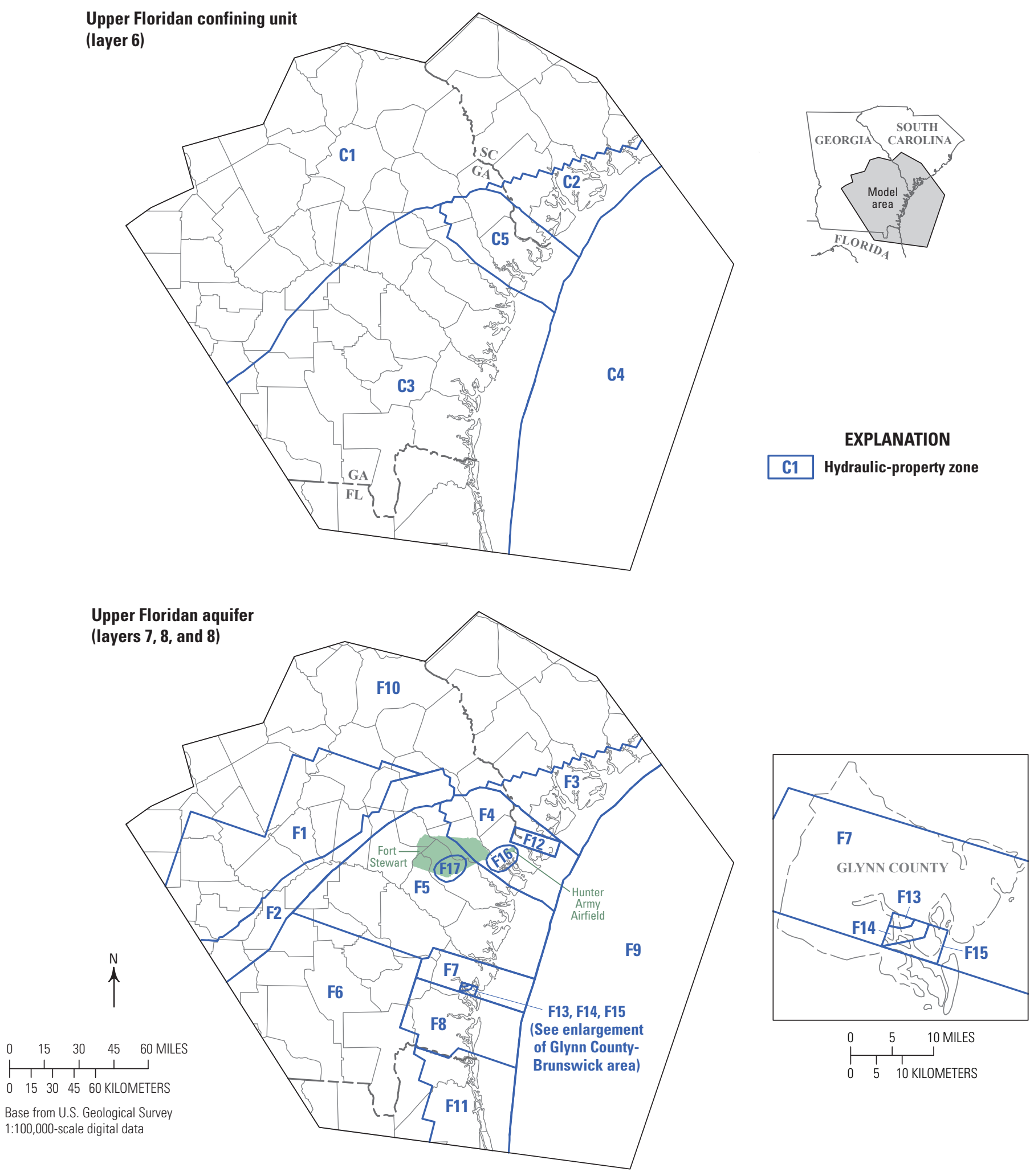

Figure 10. Hydraulic property zones for the regional model (Payne and others, 2005) near Brunswick/Glynn County, Georgia.-Continued 


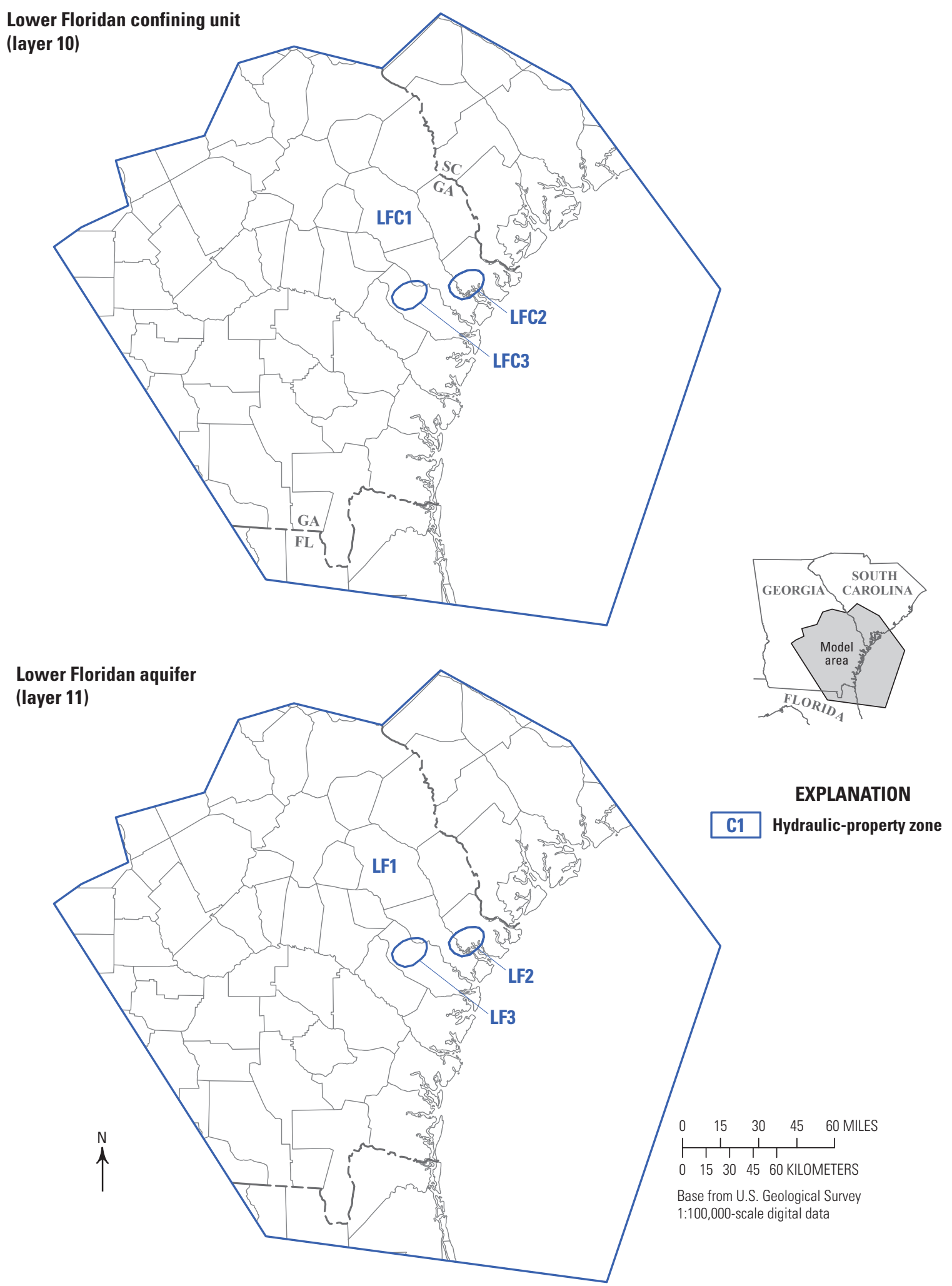

Figure 10. Hydraulic property zones for the regional model (Payne and others, 2005) near Brunswick/Glynn County, Georgia.-Continued 
For the LWBZ, the following additional aquifer property zones provided detail to the computed potentiometric surface in the Brunswick/Glynn County area that was not available from simulations using the original model:

- Zone F13 $\left(\mathrm{K}_{\mathrm{h}}=270 \mathrm{ft} / \mathrm{d}\right)$ represents a region of high groundwater flow to wells with correspondingly little groundwater-level decline.

- Zone F14 $\left(\mathrm{K}_{\mathrm{h}}=200 \mathrm{ft} / \mathrm{d}\right)$ represents a transition zone between pumping centers to the north of downtown Brunswick and low-permeability, less productive aquifer material to the south.

- Zone F15 $\left(\mathrm{K}_{\mathrm{h}}=125 \mathrm{ft} / \mathrm{d}\right)$ represents an area of lowpermeability material south of the pumping centers.

$\mathrm{A} \mathrm{K}_{\mathrm{v}}$ value of $0.2 \mathrm{ft} / \mathrm{d}$ was assigned to hydraulic property zones F7, F8, F13, F14, and F15 in the Camden/Glynn County area for the confining unit (layer 8) to allow leakage between the UWBZ and LWBZ of the UFA. This assigned $\mathrm{K}_{\mathrm{v}}$ value was the same $K_{v}$ value used for the confining unit to simulate interaquifer leakage from the UFA to the LFA in zone F17 located near Fort Stewart (Clarke and others, 2011). Outside of this subregional area consisting of five zones model layers 7, 8 and 9 representing the UFA have the same horizontal hydraulic conductivity. In general, hydraulic conductivity values were greater than those used in the original model for most of the zones in the UWBZ of the UFA (table 4), and a suitable fit between observed and simulated heads was achieved for calibration. One exception was for zones F4 and F5, where hydraulic conductivity values were decreased to better represent the cone of depression near Chatham County, Ga., with simulated groundwater levels.

Zones F16 and F17 (fig. 10) were based on the revised model's ability to simulate interaquifer leakage from the UFA to the LFA through the confining unit caused by pumping in newly constructed LFA wells near Hunter Army Airfield and Fort Stewart, Ga. (Clarke and others, 2010 and 2011). Based on 72-hour aquifer tests, two distinct zones of hydraulic conductivity were created in modified models of these areas to simulate hydraulic property variations in the lower confining unit of the LFA (fig. 10; table 4).

\section{Boundary Conditions}

Boundaries used in the revised model generally conformed to those used in the original model and are based on locations of natural-flow boundaries where available (figs. 7 and 8). Artificial boundaries were used where natural-flow boundaries were unavailable. Payne and others (2005) contains a complete discussion of boundary conditions used in the original model. The main adjustments to boundaries in the revised model involve updated changes to reflect hydrologic conditions during 2004, including adjustment of groundwater levels along specified-head boundaries.

\section{Vertical Boundaries}

The lowermost boundary represents the no-flow condition present at the contact between the LFA (layer 11) and underlying low-permeability sediments of Paleocene age and older. The altitude of this no-flow boundary varies greatly over the model area and depends on the orientation of this contact with regard to geologic structure (strike and dip). In general, this no-flow boundary reaches its greatest depth near the Southeast Georgia Embayment.

The uppermost boundary of the revised model represents a general-head condition; controlling heads represent the estimated water table for onshore areas (Peck and Payne, 2003), and a conductance term helps regulate the amount of recharge to, or discharge from, onshore and offshore areas. In the onshore area, this boundary condition was applied to the uppermost active aquifer cell in the model, which could be layer 1 , 2 , or 5, depending on which unit crops out at land surface. The conductance term and the simulated and controlling hydraulic heads along the boundary contributed to model computations of reasonable recharge rates that were compared with those derived from base-flow calculations (Priest, 2004) and others associated with similar hydrologic settings (Williamson and others, 1990). The general-head boundary represents a sourcesink boundary in the unconfined portion of the surficial aquifer that facilitates water exchange into (recharge) and out of (discharge) the confined, regional groundwater system.

In the offshore area, a general-head boundary was placed above the top active cells of model layer 1 . The controlling head in this area of the model represents the freshwater equivalent of the saltwater head; hydraulic conductance is assumed to be constant; and thickness between the controlling head and active cells of layer 1 generally is limited to several feet. Sensitivity analyses performed on the parameters that define the general-head boundary indicated that their values do not substantially affect simulated results, and that flow from the confined system in the offshore area is assumed to be controlled predominantly by the hydraulic properties of the confining units, model layers 2 through 6 .

\section{Lateral Boundaries}

Lateral boundary conditions for the revised model were selected to coincide as closely with assumed no-flow boundaries or groundwater divides as defined by Payne and others (2005) in the original model. With the exception of the Floridan aquifer system (layers 7-11), lateral boundaries for all other layers are designated as no-flow boundaries.

Simulated flow in the Floridan aquifer system is bounded laterally by a combination of no-flow and specified-head boundaries. The northwestern boundary of the model is defined as a no-flow boundary because it is located at the approximate updip extent of the Floridan aquifer system or its equivalent, as defined by Miller (1986). The onshore part of the northeastern flow boundary was designated as a no-flow boundary because, according to Ransom and White (1999), estimated flow lines drawn on the potentiometric-surface map indicate parallel flow to this boundary. This boundary also extends offshore and is connected to the eastern no-flow boundary.

To the southwest and south of the model area, the Floridan aquifer system extends beyond the model boundaries; 
therefore, a specified-head boundary was used to allow flow into the model. The original model assigned values to the specified-head boundary based on potentiometric surfaces of the UFA that correspond to specific years of the simulation to incorporate temporal changes in head that affect flow patterns and directions. Potentiometric-surface maps for May 1980 (Johnston and others, 1981), May 1998 (Peck and others, 1999), and September 2000 (Peck and McFadden, 2004) were used to assign heads along the specified-head boundary.

Heads along the southwestern boundary in the revised model were adjusted on the basis of observed water-level changes presented by Peck and others (2004). Water levels near the southwestern boundary were affected by the shutdown of the Durango Paper Company mill near St. Marys, Camden County, during 2002, which caused 5- to 10-ft waterlevel rises in the UFA by May 2003 (Peck and others, 2004). Specified-head values were adjusted accordingly in the UWBZ (layer 7) and LWBZ (layer 9) and the intervening confining unit (layer 8) to account for the increased water levels. Similarly, heads also were changed in the LFA (layer 11) and overlying confining unit (layer 10).

\section{Groundwater Withdrawals}

Groundwater withdrawals were compiled for input to the revised model in preparation for steady-state simulation of 2000 and 2004 conditions. Pumpage for 2004 was estimated using site-specific data for 2004 and county-aggregate estimates for 2000. Year 2000 estimates were used for 2004 because estimated values were not available for that year. Pumpage was assigned to nodes of the model cells using procedures described in Taylor and others (2003).

Pumpage assigned to single layers in the original model was redistributed to multiple layers representing the Brunswick and Floridan aquifer systems in the revised model based on the thickness of the aquifers, or water-bearing zones, because the actual contribution to pumpage from each water-bearing zone could not be determined. The redistribution of pumpage from single layers in the original model to one or more layers in the revised model involved the following reassignments:

- Brunswick aquifer system-layer 3 (original model) reassigned to layers 3 and 5 (revised model) to represent pumpage in the upper and lower Brunswick aquifers, respectively;

- UFA-layer 5 (original model) reassigned to layers 7 and 9 (revised model) to represent pumpage in the UWBZ and LWBZ, respectively;

- LFA-layer 7 (original model) represented as pumpage in layer 11 (revised model).

For the 2000 simulation, pumpage was aggregated to nodal locations in the model grid in model layers 3 and 5 (Brunswick aquifer system, fig. 11). Nodes representing pumpage in the multiple layers of the revised model corresponded with the nodal locations of pumpage in the single layer of the original model. Pumpage at actual well locations was not represented as such in the original model nor the revised model.

For the 2004 simulation, pumpage was identified at specific well locations in the Brunswick aquifer system in the Glynn County area (fig. 12). This pumpage was represented in the revised model as simulated withdrawal at the closest nodes in the model grid.

The 2000 and the 2004 steady-state simulations both show pumping centers in the UFA (layers 7 and 9) near Savannah, Jesup, and Brunswick, Ga. (figs. $11 C-D$ and $12 C-D$ ). Production wells open to the UFA were assumed to penetrate the entire aquifer and pumping was distributed based on the thickness of the UWBZ and LWBZ of the UFA (layers 7 and 9). During the 2004 simulation, pumping was eliminated at the Durango Paper Company mill near St. Marys for a reduction of $36 \mathrm{Mgal} / \mathrm{d}$ in model layers 7 and 9 (fig. $12 C-D$ ). In the Brunswick/Glynn County area, the number of active industrial production wells decreased in the northern part of the city. Water-supply wells near Brunswick generally are open to the UWBZ and LWBZ, but do not tap water-bearing units beneath the UFA (L. Elliott Jones, U.S. Geological Survey, written commun., 2014). Current-meter data and well depth information at the Pinova and GP Cellulose well fields indicate that the estimated contribution from the UWBZ to total water pumped from the UFA ranged between 30 to 45 percent (Jones and Maslia, 1994; L. Elliott Jones, U.S. Geological Survey, written commun., 2014). Pumping in the LFA (layer 11) is concentrated mostly north of Jacksonville, Fla., in both simulations, with pumpage from some active wells located in Chatham County, Ga., during the 2000 simulation.

\section{Model Calibration}

The revised model was calibrated by adjusting hydraulic properties and boundary conditions so that simulated groundwater levels reasonably matched observed water levels during 2004. Although initial simulations utilized hydraulic properties derived from calibration of the original model, an improved match of simulated to observed groundwater levels was obtained for the UWBZ and upper and lower Brunswick aquifers with the revised model by rezoning and adjusting hydraulic conductivity values in the Brunswick/Glynn County area. The revised model was further evaluated using pumping estimates for 2000 in conjunction with observed water levels during 2000 to obtain the best possible match of simulated to observed water levels in the Brunswick/Glynn County area. Additionally, the calibrated revised model allowed grid refinement near the area of chloride contamination in the City of Brunswick to accurately simulate hydraulic gradients and groundwater-flow directions near industrial pumping centers. The simulated hydraulic gradients, or potentiometric gradients, near downtown Brunswick are important because they control the direction and rate of chloride movement within the plume area. Changes in potentiometric gradients over extended periods could alter the shape and the extent of the chloride plume. 
$\boldsymbol{A}$
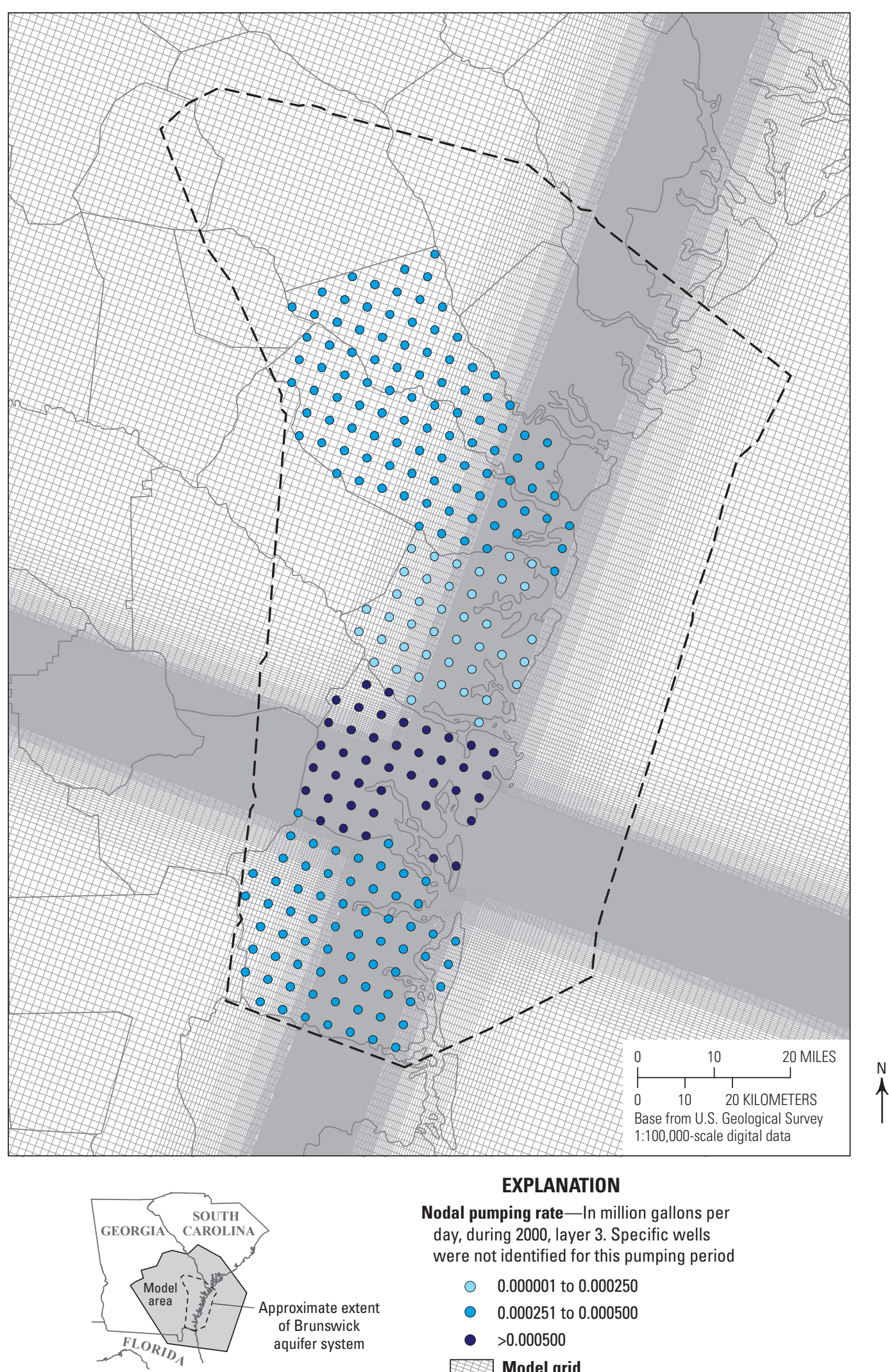

EXPLANATION

Nodal pumping rate - In million gallons per day, during 2000, layer 3 . Specific wells were not identified for this pumping period

0.000001 to 0.000250

0.000251 to 0.000500

- $>0.000500$

Model grid

Figure 11. Distribution of groundwater pumpage for 2000 for $A$, model layer 3, upper Brunswick aquifer; $B$, model layer 5 , lower Brunswick aquifer; $C$, model layer 7 , Upper Floridan aquifer upper water-bearing zone; $D$, model layer 9 , Upper Floridan aquifer lower water-bearing zone; and $E$, model layer 11, Lower Floridan aquifer. 

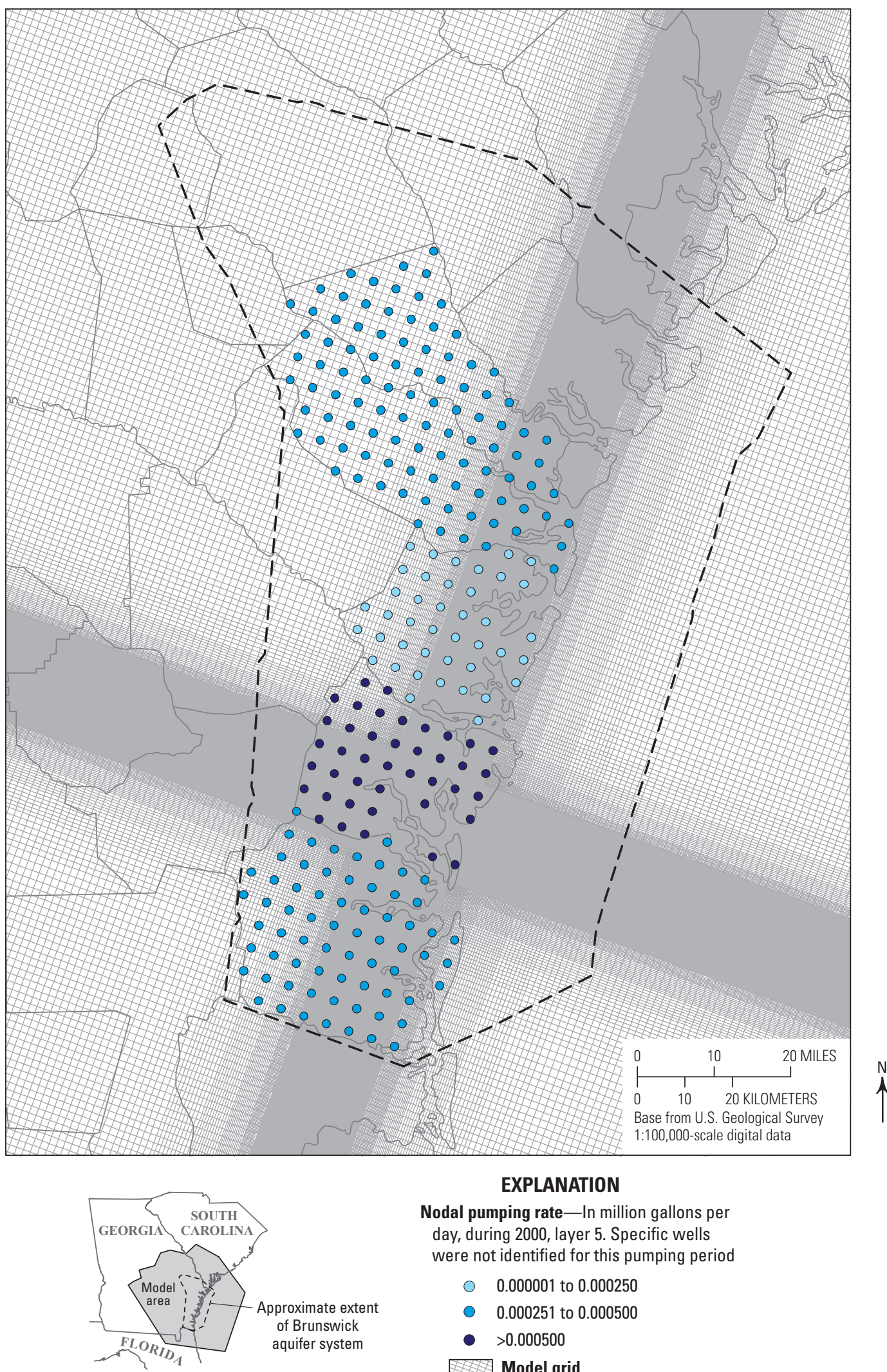

\section{EXPLANATION}

Nodal pumping rate - In million gallons per day, during 2000 , layer 5 . Specific wells were not identified for this pumping period

0.000001 to 0.000250

0.000251 to 0.000500

- $>0.000500$

Model grid

Figure 11. Distribution of groundwater pumpage for 2000 for $A$, model layer 3, upper Brunswick aquifer; $B$, model layer 5 , lower Brunswick aquifer; $C$, model layer 7 , Upper Floridan aquifer upper water-bearing zone; $D$, model layer 9 , Upper Floridan aquifer lower water-bearing zone; and $E$, model layer 11, Lower Floridan aquifer.-Continued 
C

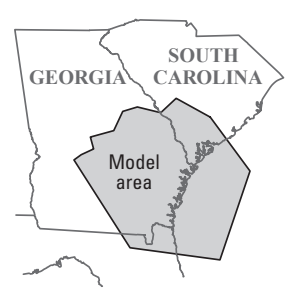

EXPLANATION

Pumping rate per well-In million gallons per day, during 2000, layer 7

○ $<0.1$

○ 0.1 to 0.5

- $>0.5$ to 1.0

- $>1.0$ to 2.0

- $>2.0$

Model grid

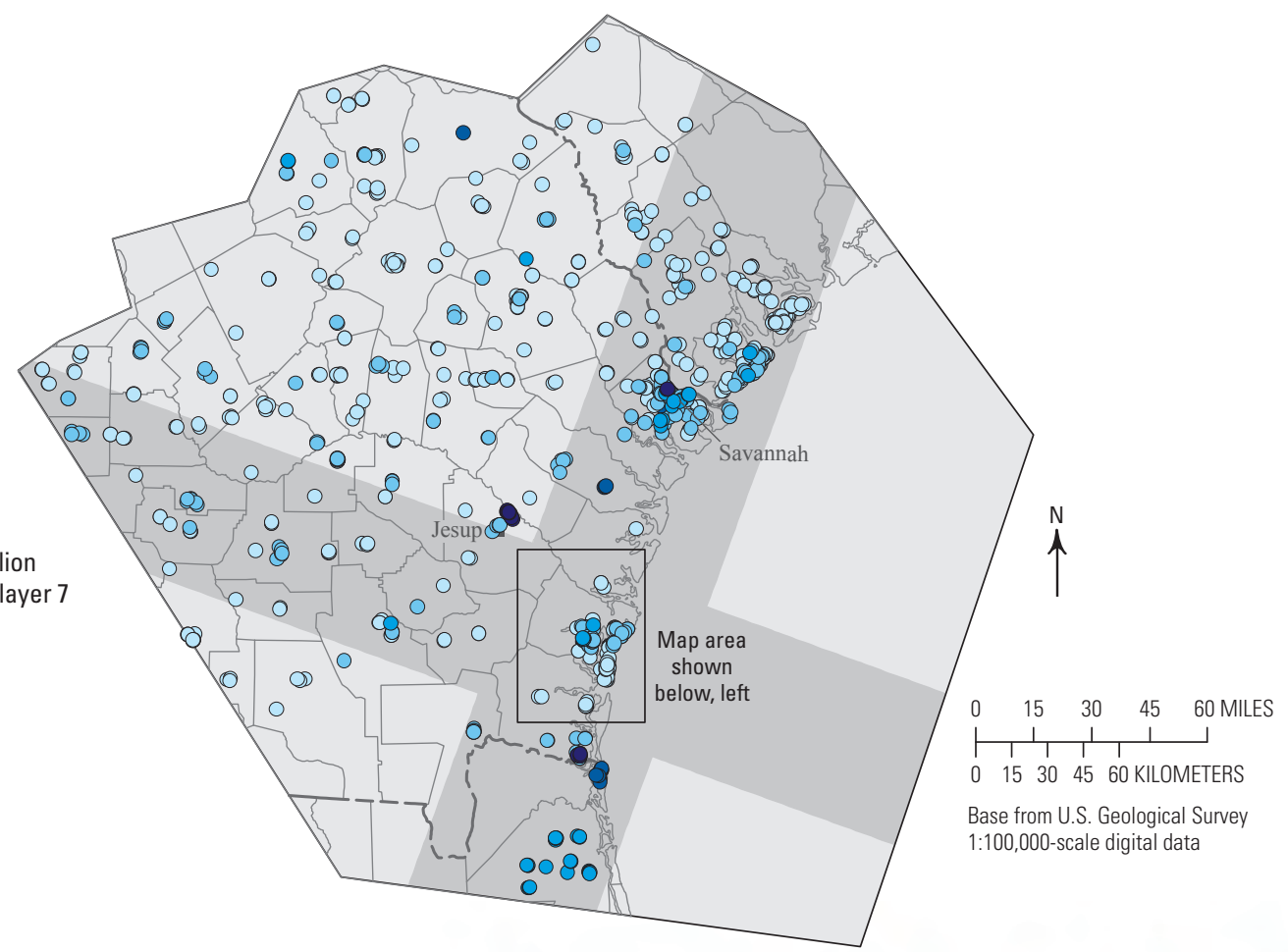

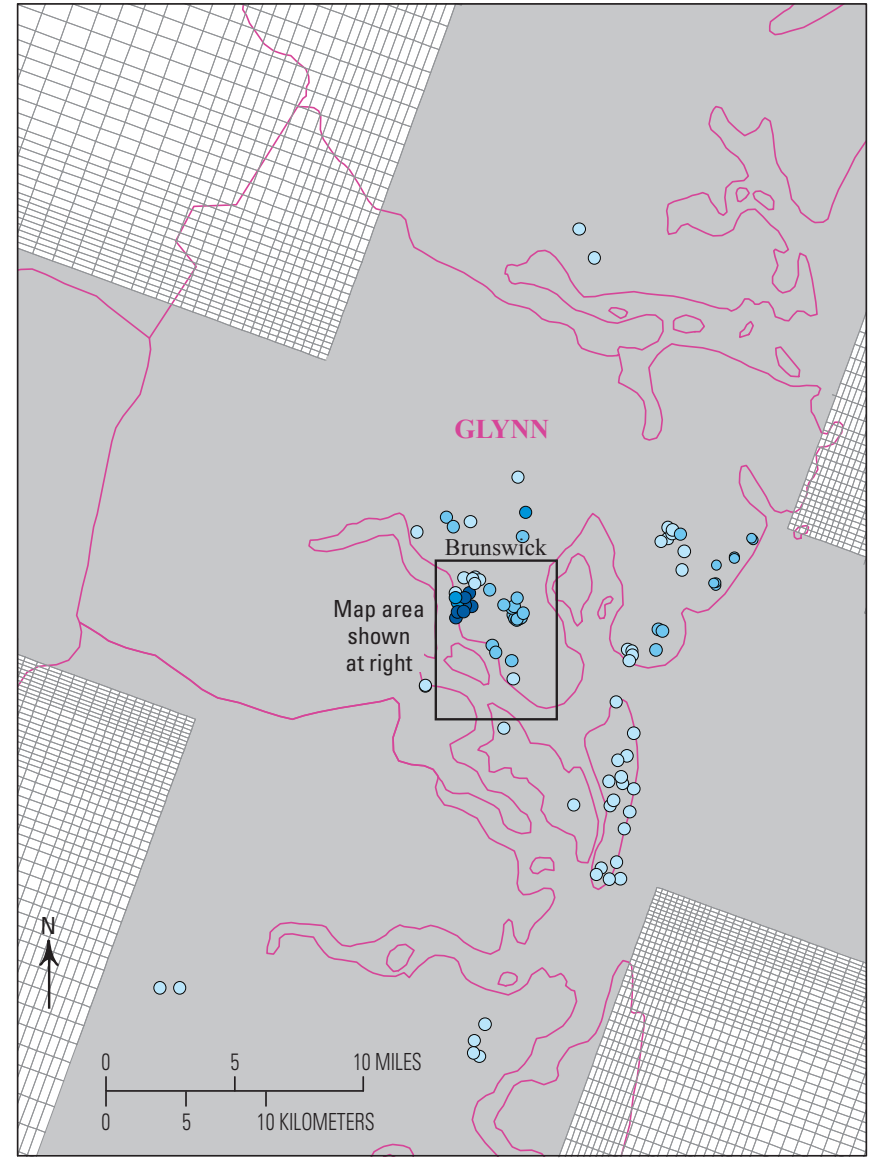

Base from U.S. Geological Survey 1:100,000-scale digital data

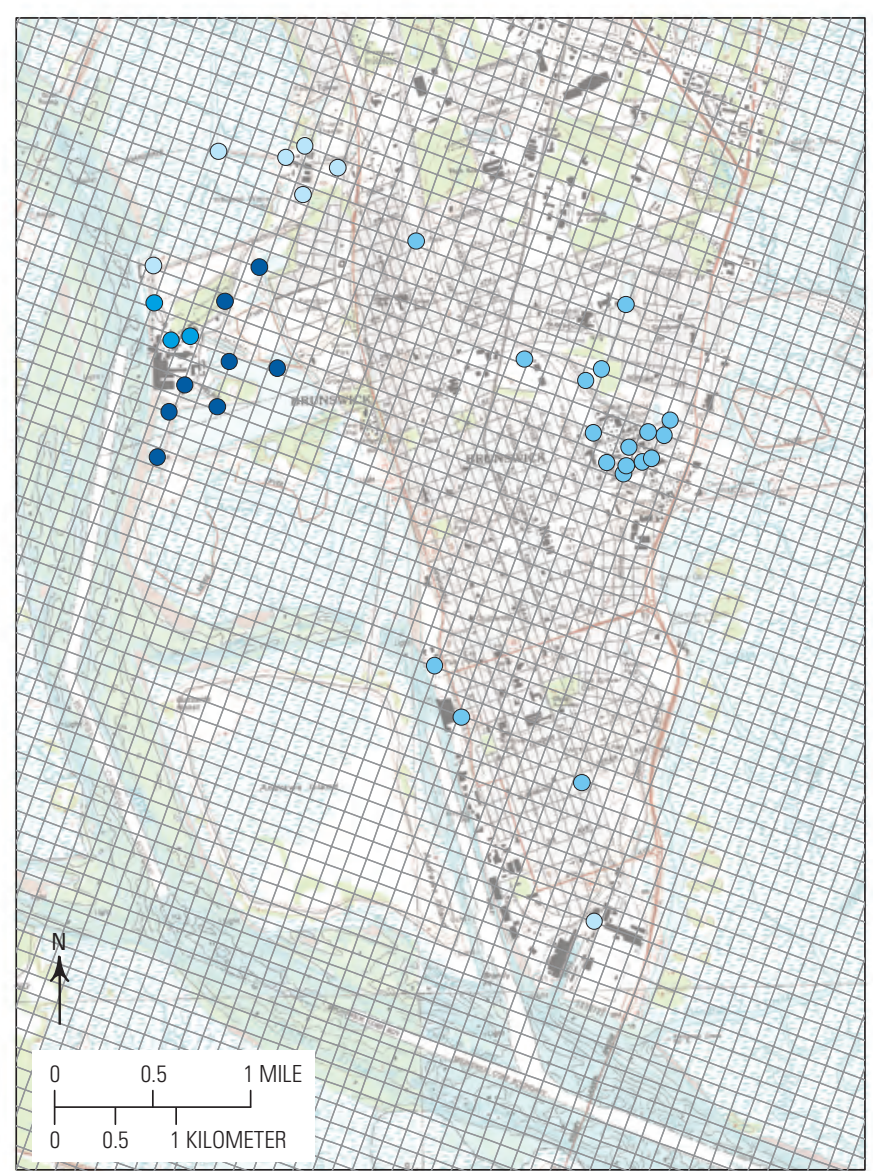

Base from U.S. Geological Survey digital files, 1:24,000, Brunswick West, 1993; Brunswick East, 1979

Figure 11. Distribution of groundwater pumpage for 2000 for $A$, model layer 3 , upper Brunswick aquifer; $B$, model layer 5 , lower Brunswick aquifer; $C$, model layer 7 , Upper Floridan aquifer upper water-bearing zone; $D$, model layer 9 , Upper Floridan aquifer lower water-bearing zone; and $E$, model layer 11, Lower Floridan aquifer.-Continued 


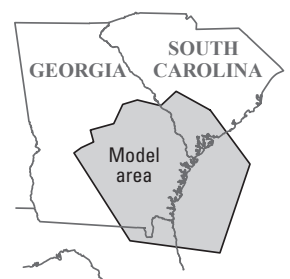

EXPLANATION

Pumping rate per well-In million gallons per day, during 2000, layer 9

○ $<0.1$

○ 0.1 to 0.5

- $>0.5$ to 1.0

- $>1.0$ to 2.0

- $>2.0$

Model grid

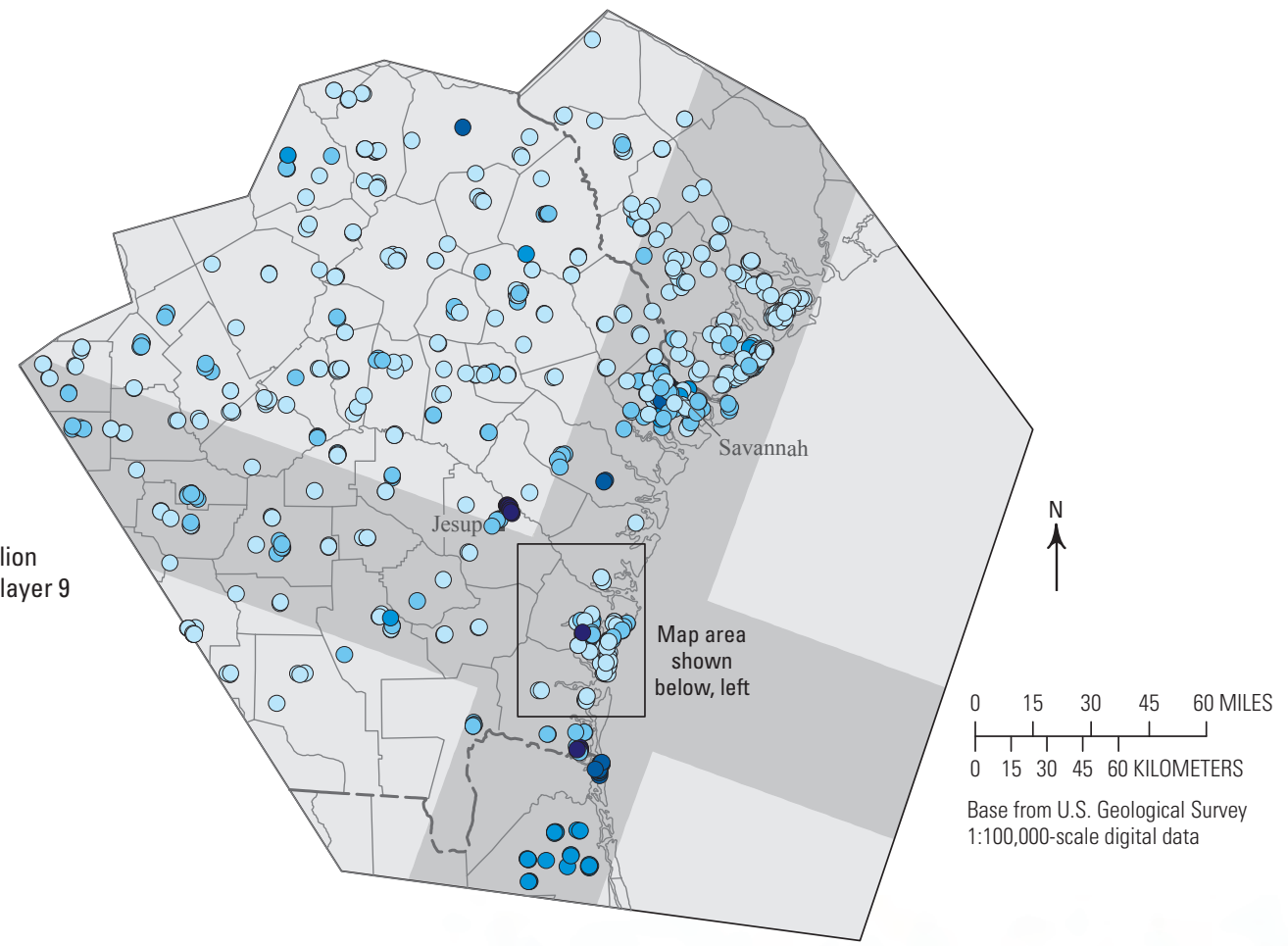

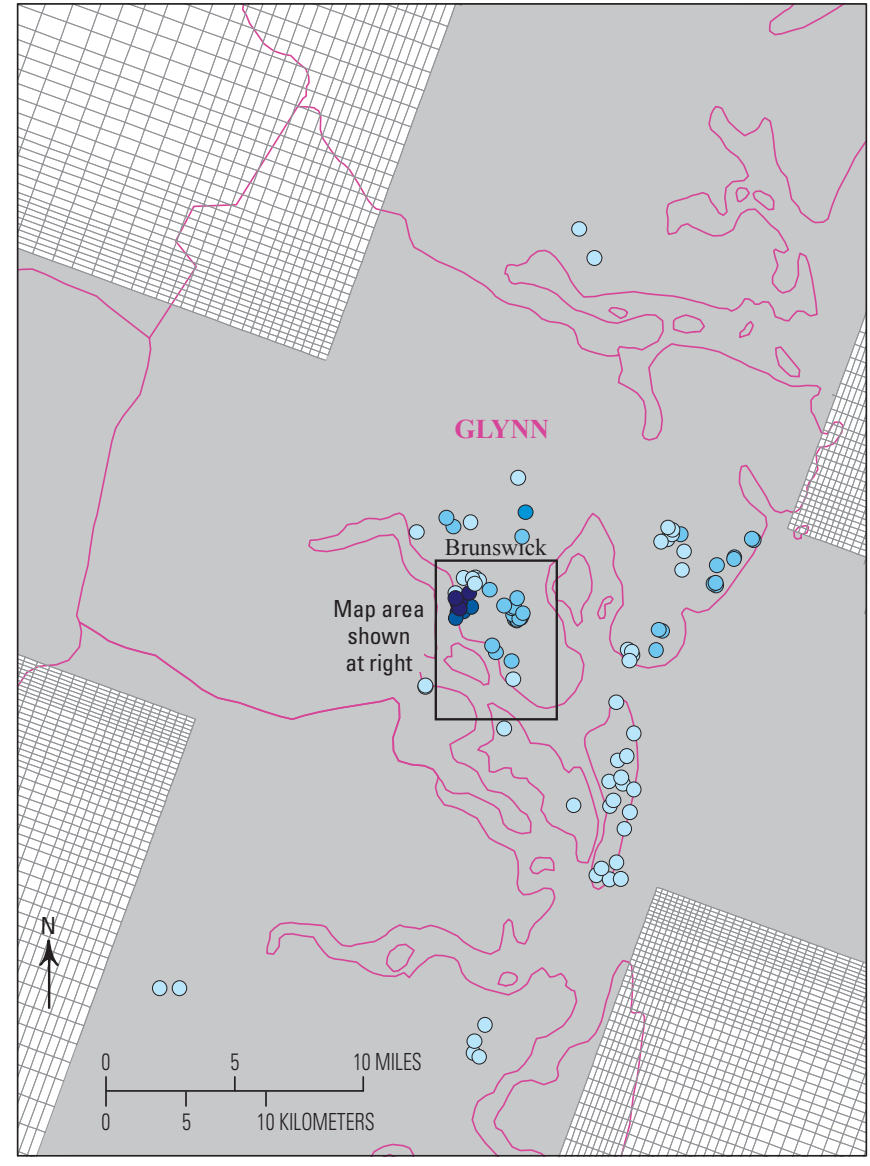

Base from U.S. Geological Survey 1:100,000-scale digital data

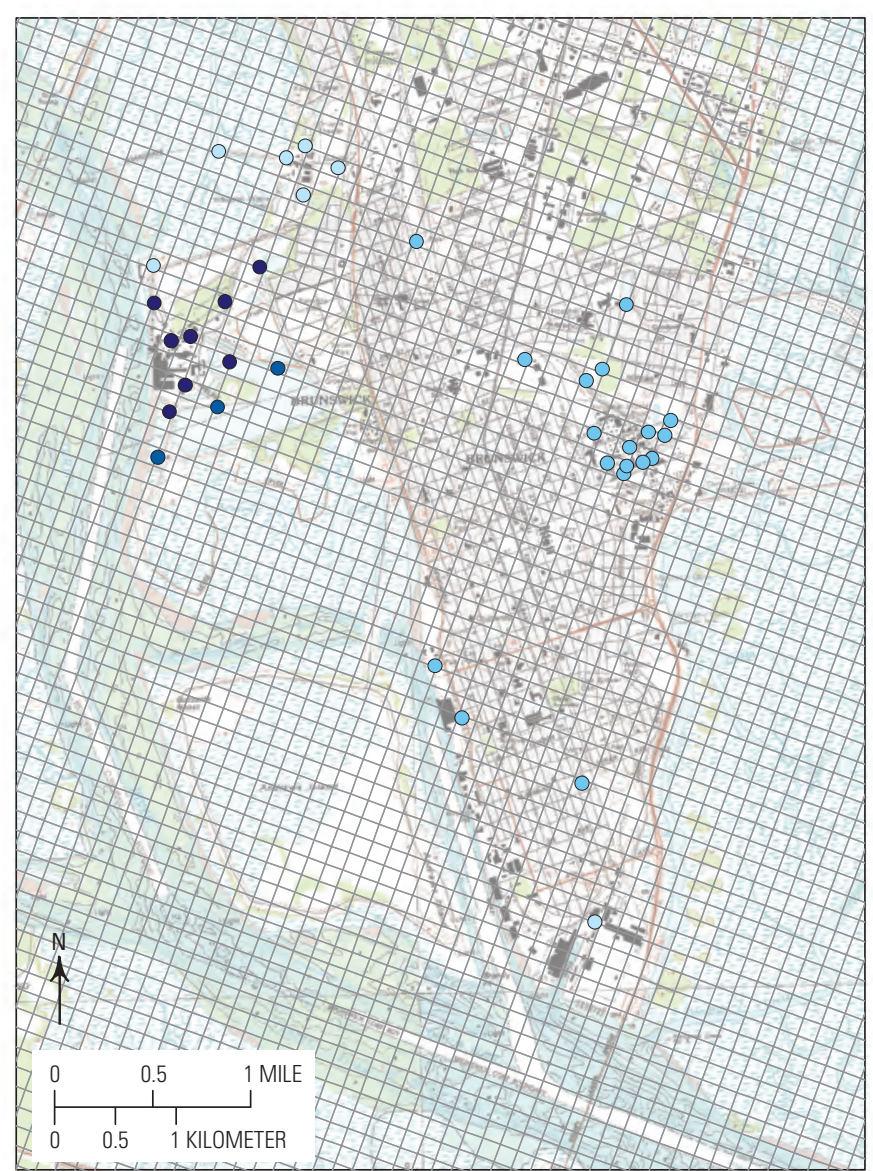

Base from U.S. Geological Survey digital files, 1:24,000, Brunswick West, 1993; Brunswick East, 1979

Figure 11. Distribution of groundwater pumpage for 2000 for $A$, model layer 3 , upper Brunswick aquifer; $B$, model layer 5 , lower Brunswick aquifer; $C$, model layer 7 , Upper Floridan aquifer upper water-bearing zone; $D$, model layer 9 , Upper Floridan aquifer lower water-bearing zone; and $E$, model layer 11, Lower Floridan aquifer.-Continued 
$\boldsymbol{E}$
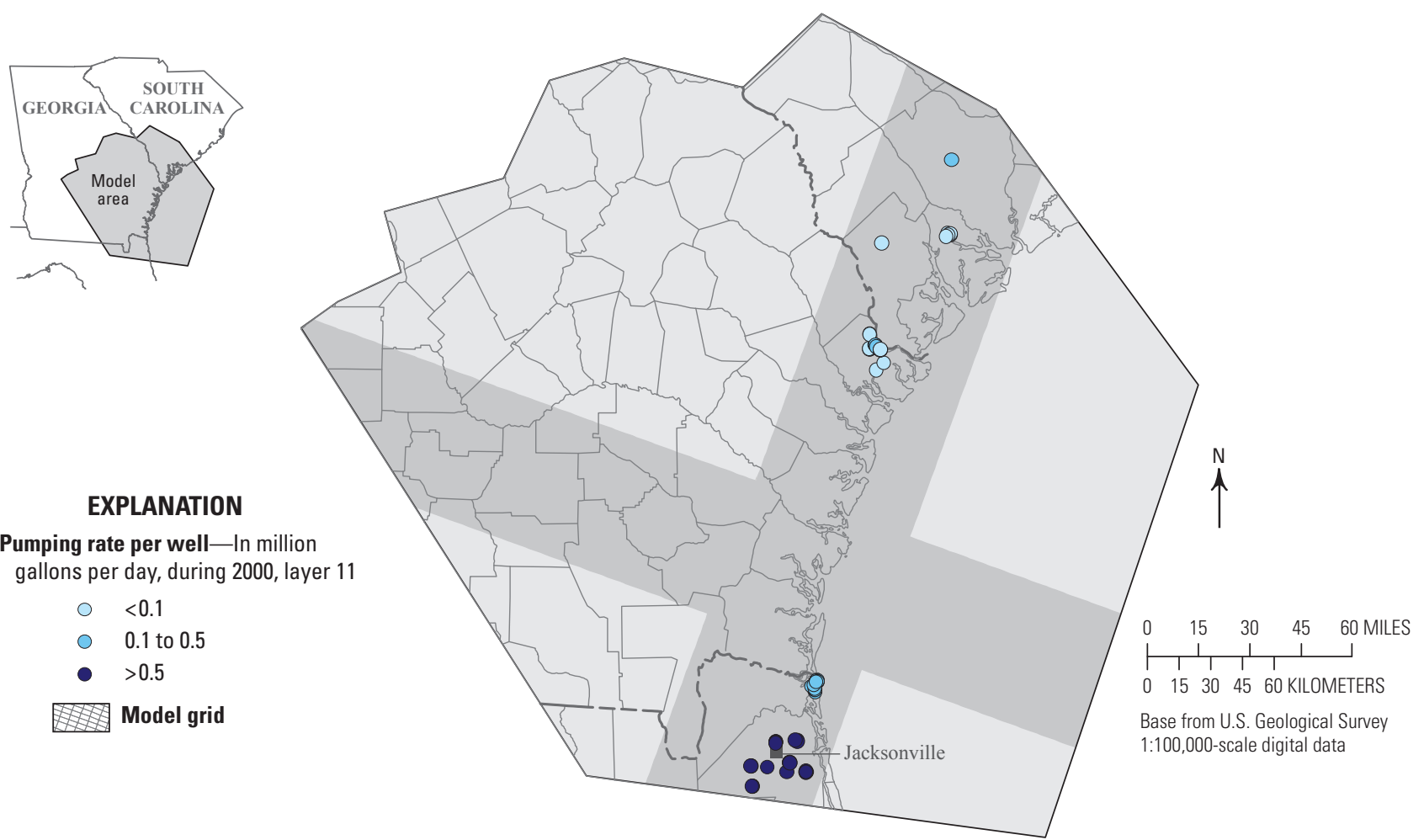

Figure 11. Distribution of groundwater pumpage for 2000 for $A$, model layer 3 , upper Brunswick aquifer; $B$, model layer 5 , lower Brunswick aquifer; $C$, model layer 7, Upper Floridan aquifer upper water-bearing zone; $D$, model layer 9 , Upper Floridan aquifer lower water-bearing zone; and $E$, model layer 11, Lower Floridan aquifer-Continued 
$\boldsymbol{A}$
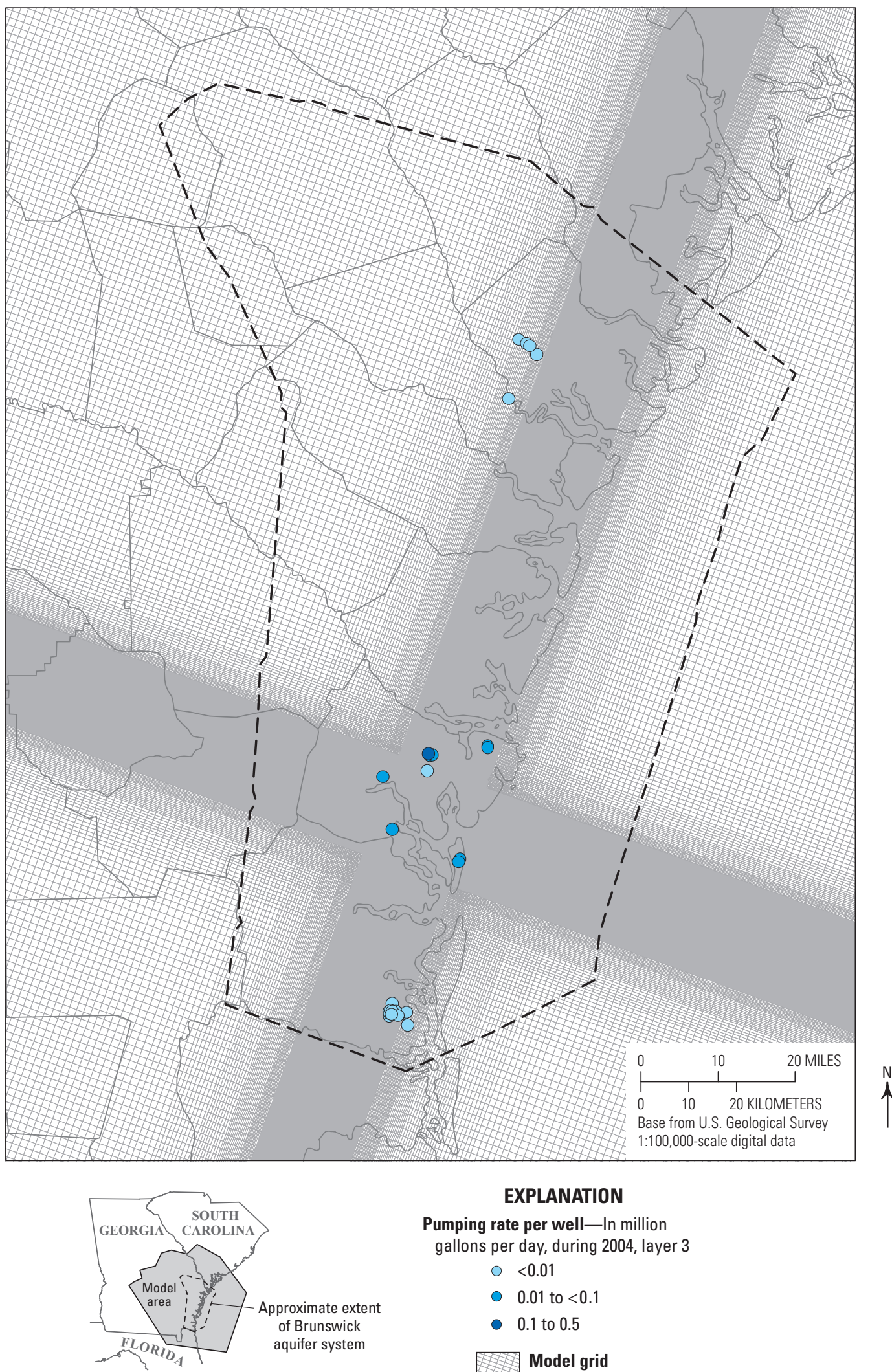

\section{EXPLANATION}

Pumping rate per well-In million gallons per day, during 2004, layer 3

$0<0.01$

- 0.01 to $<0.1$

- 0.1 to 0.5

Model grid

Figure 12. Distribution of groundwater pumpage for 2004 for $A$, model layer 3, upper Brunswick aquifer; $B$, model layer 5 , lower Brunswick aquifer; $C$, model layer 7 , Upper Floridan aquifer upper water-bearing zone; $D$, model layer 9 , Upper Floridan aquifer lower water-bearing zone; and $E$, model layer 11, Lower Floridan aquifer. 
B
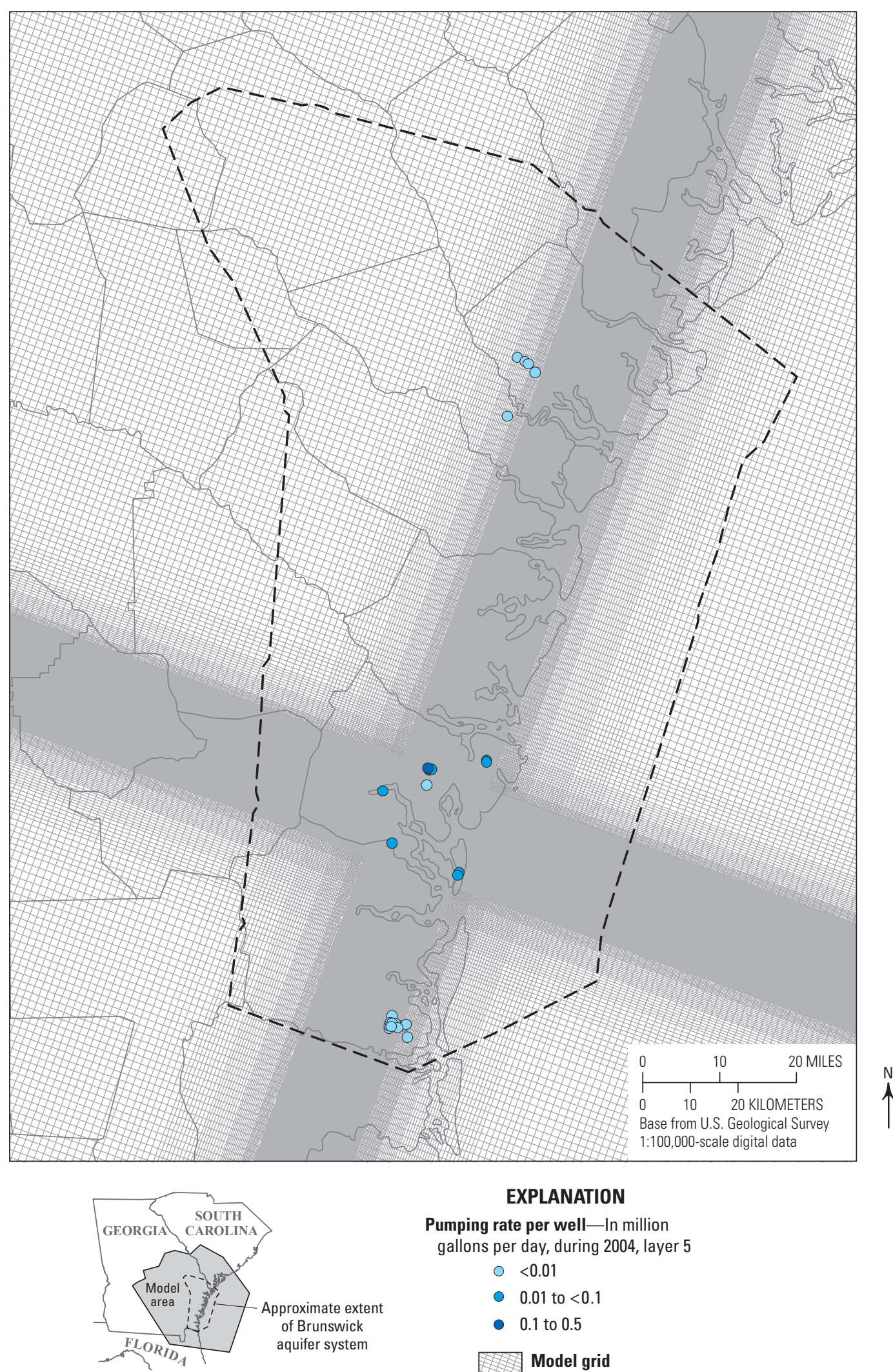

\section{EXPLANATION}

Pumping rate per well-In million

gallons per day, during 2004, layer 5

$\circ<0.01$

0.01 to $<0.1$

- 0.1 to 0.5

Model grid

Figure 12. Distribution of groundwater pumpage for 2004 for $A$, model layer 3, upper Brunswick aquifer; $B$, model layer 5 , lower Brunswick aquifer; $C$, model layer 7, Upper Floridan aquifer upper water-bearing zone; $D$, model layer 9 , Upper Floridan aquifer lower water-bearing zone; and $E$, model layer 11, Lower Floridan aquifer.-Continued 
C

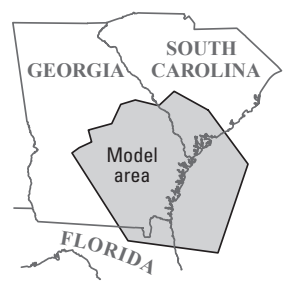

EXPLANATION

Pumping rate per well-In million gallons per day, during 2004, layer 7

$0<0.1$

0.1 to 0.5

- $>0.5$ to 1.0

$>1.0$ to 2.0

- $>2.0$

Model grid

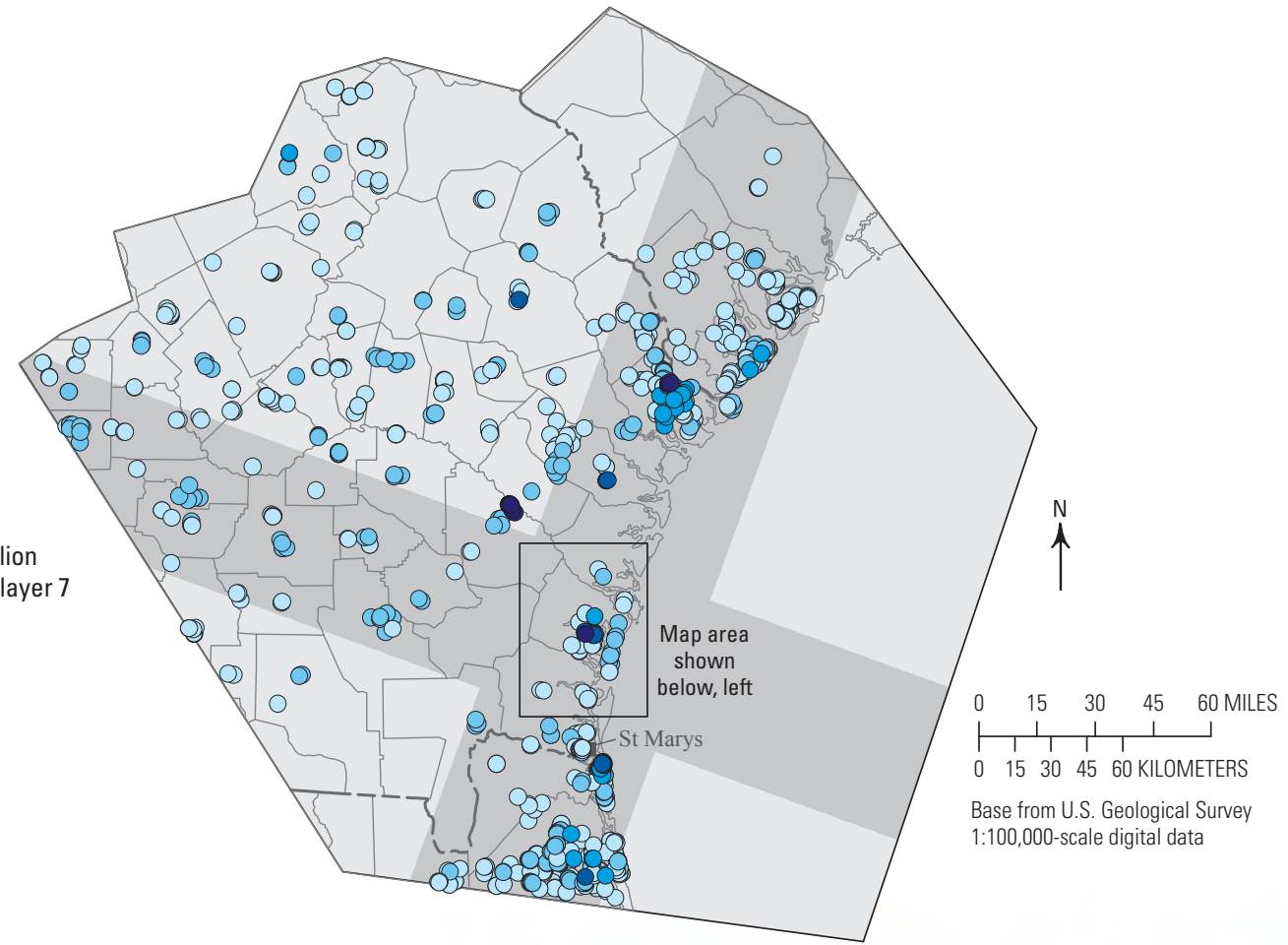

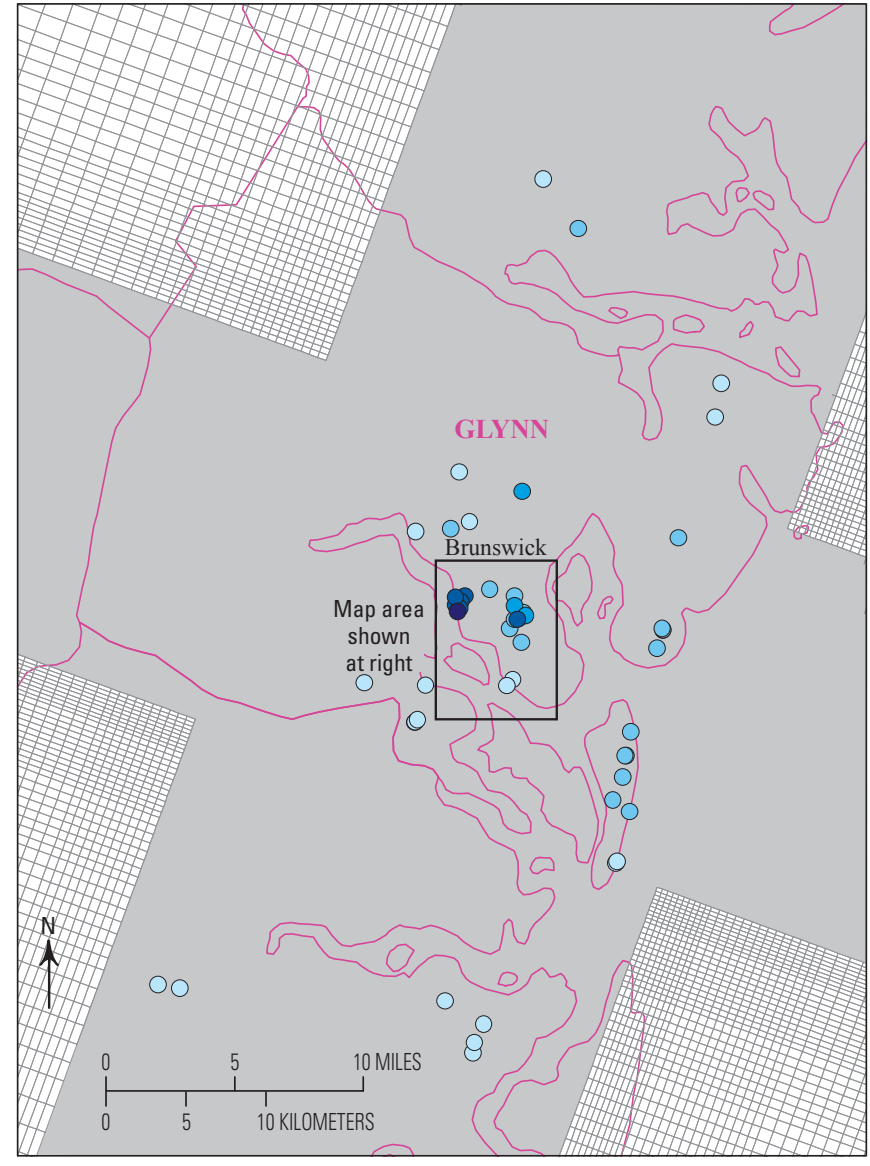

Base from U.S. Geological Survey 1:100,000-scale digital data

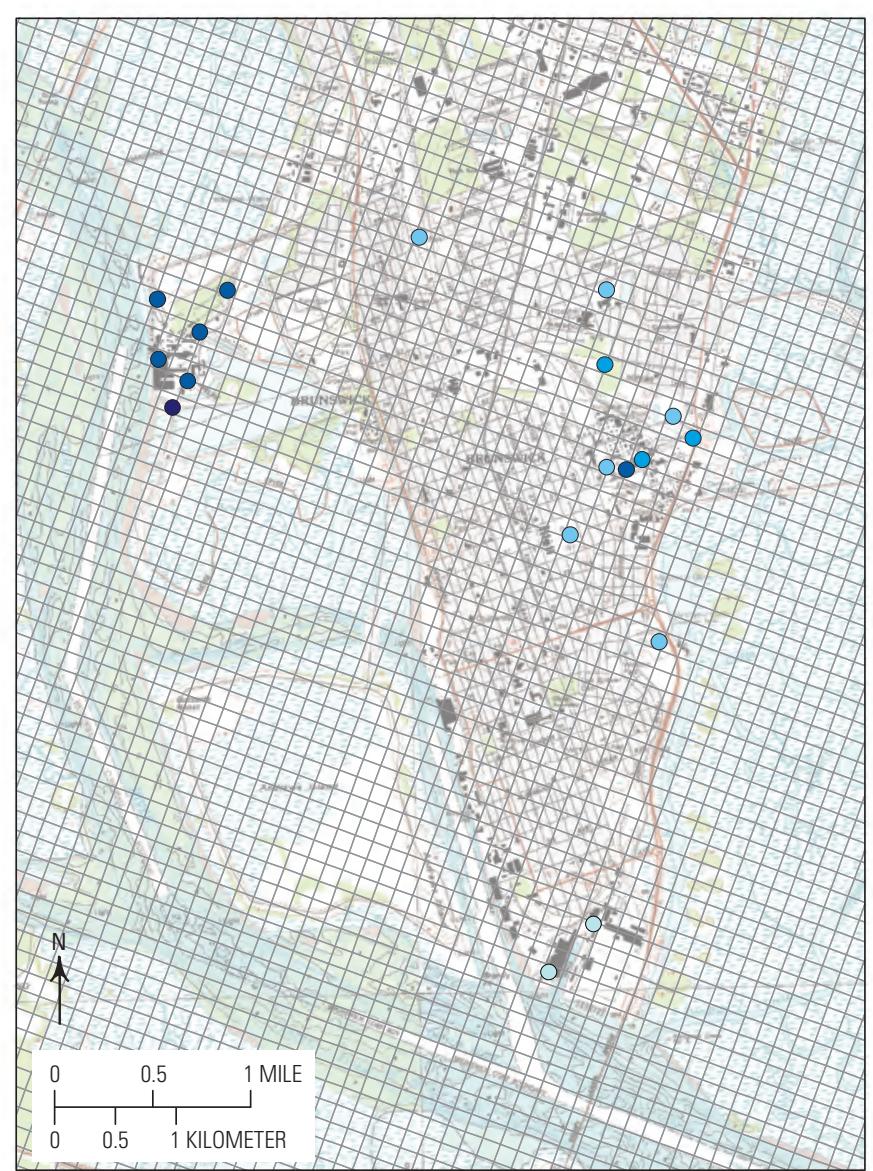

Base from U.S. Geological Survey digital files, 1:24,000, Brunswick West, 1993; Brunswick East, 1979

Figure 12. Distribution of groundwater pumpage for 2004 for $A$, model layer 3 , upper Brunswick aquifer; $B$, model layer 5 , lower Brunswick aquifer; $C$, model layer 7 , Upper Floridan aquifer upper water-bearing zone; $D$, model layer 9 , Upper Floridan aquifer lower water-bearing zone; and $E$, model layer 11, Lower Floridan aquifer-Continued 

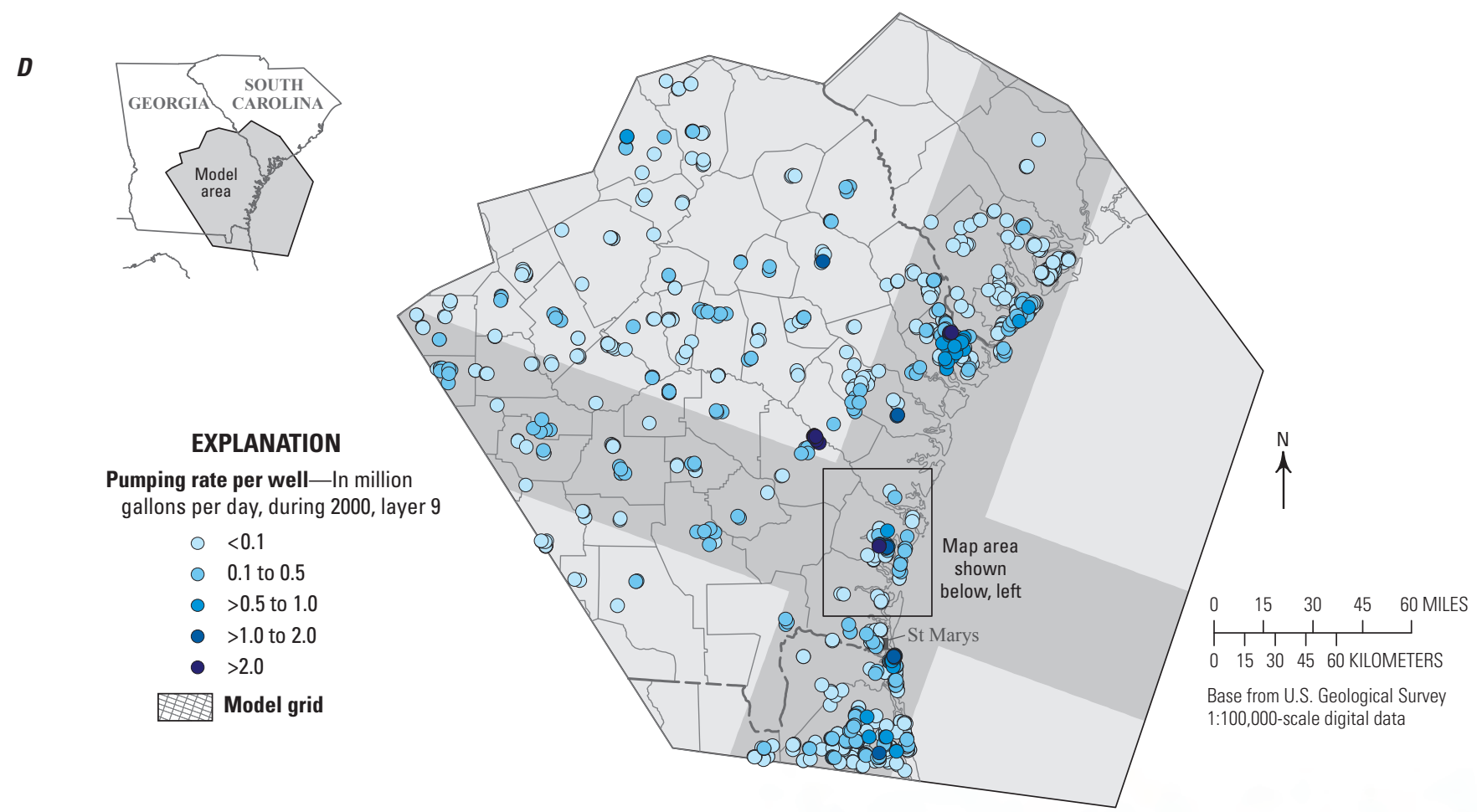

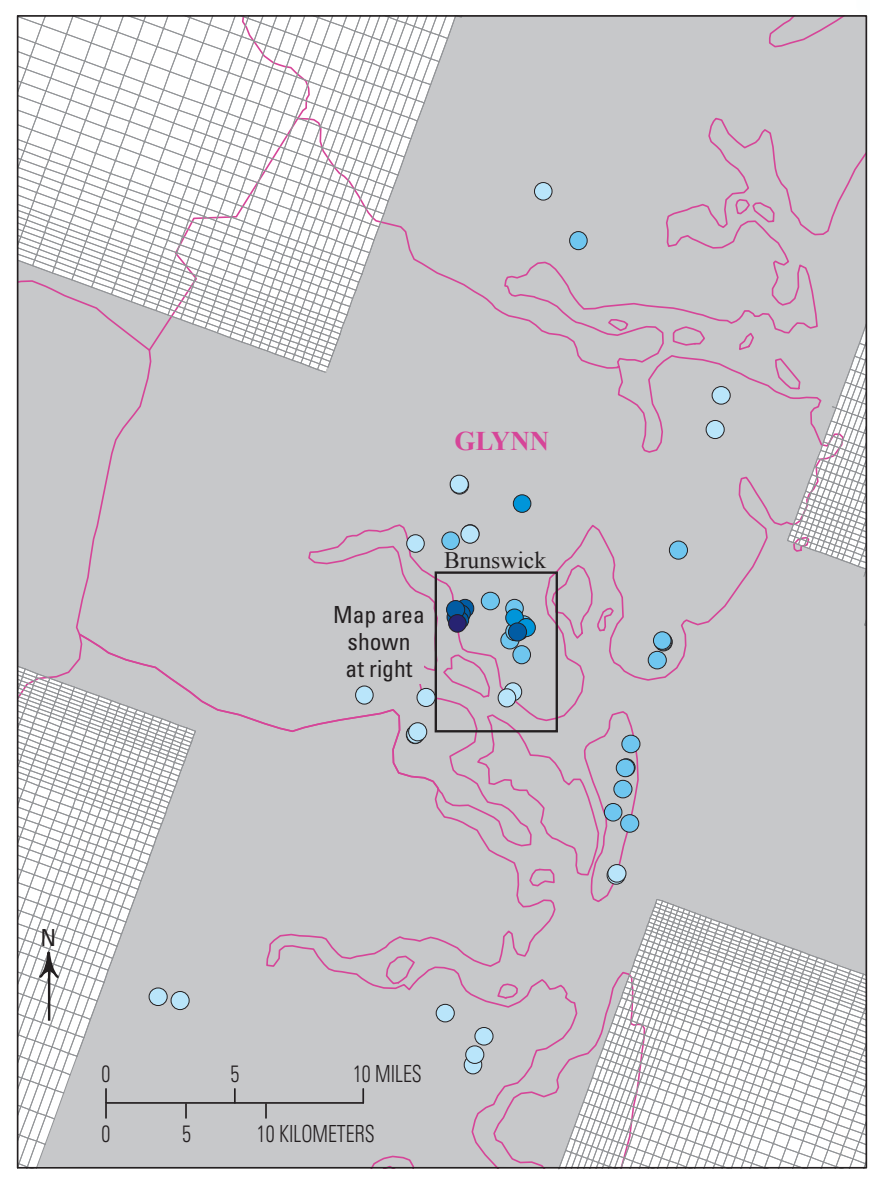

Base from U.S. Geological Survey 1:100,000-scale digital data

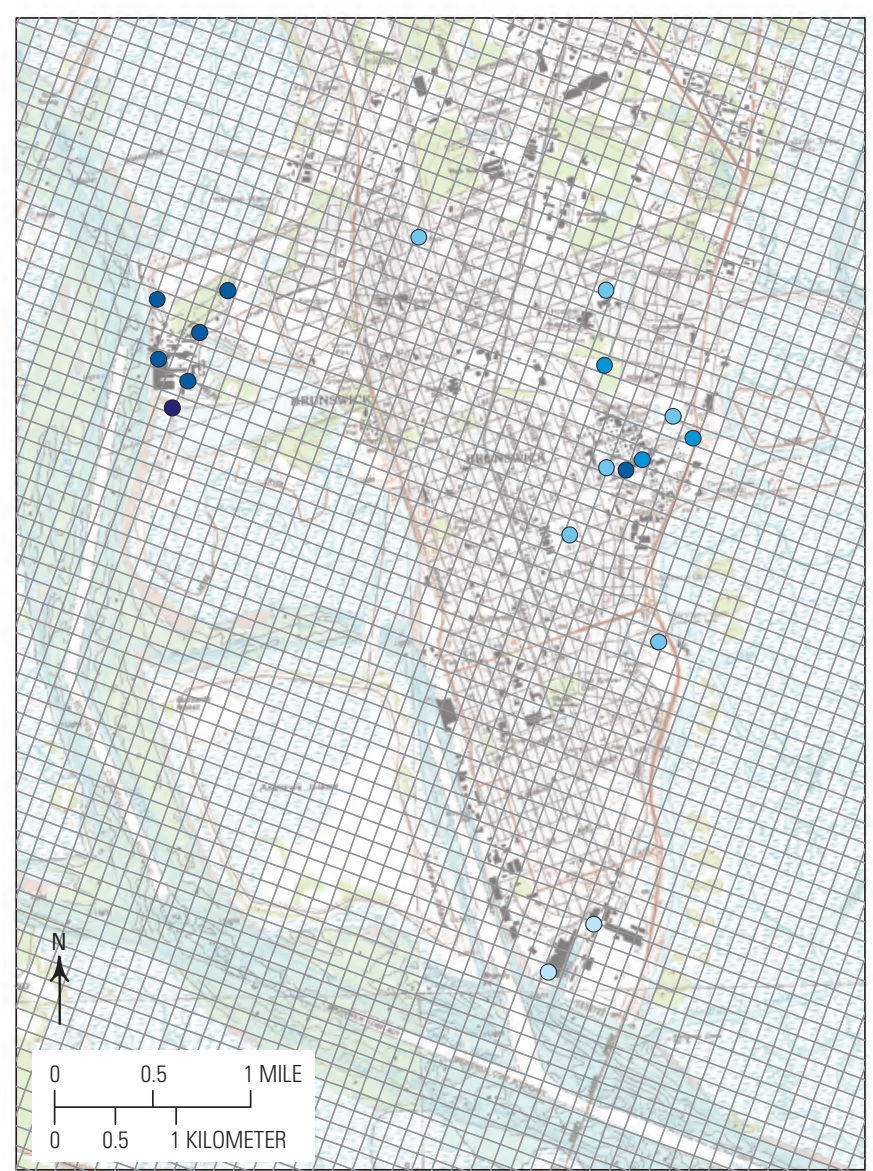

Base from U.S. Geological Survey digital files,1:24,000, Brunswick West, 1993; Brunswick East, 1979

Figure 12. Distribution of groundwater pumpage for 2004 for $A$, model layer 3 , upper Brunswick aquifer; $B$, model layer 5 , lower Brunswick aquifer; $C$, model layer 7 , Upper Floridan aquifer upper water-bearing zone; $D$, model layer 9 , Upper Floridan aquifer lower water-bearing zone; and $E$, model layer 11, Lower Floridan aquifer.-Continued 

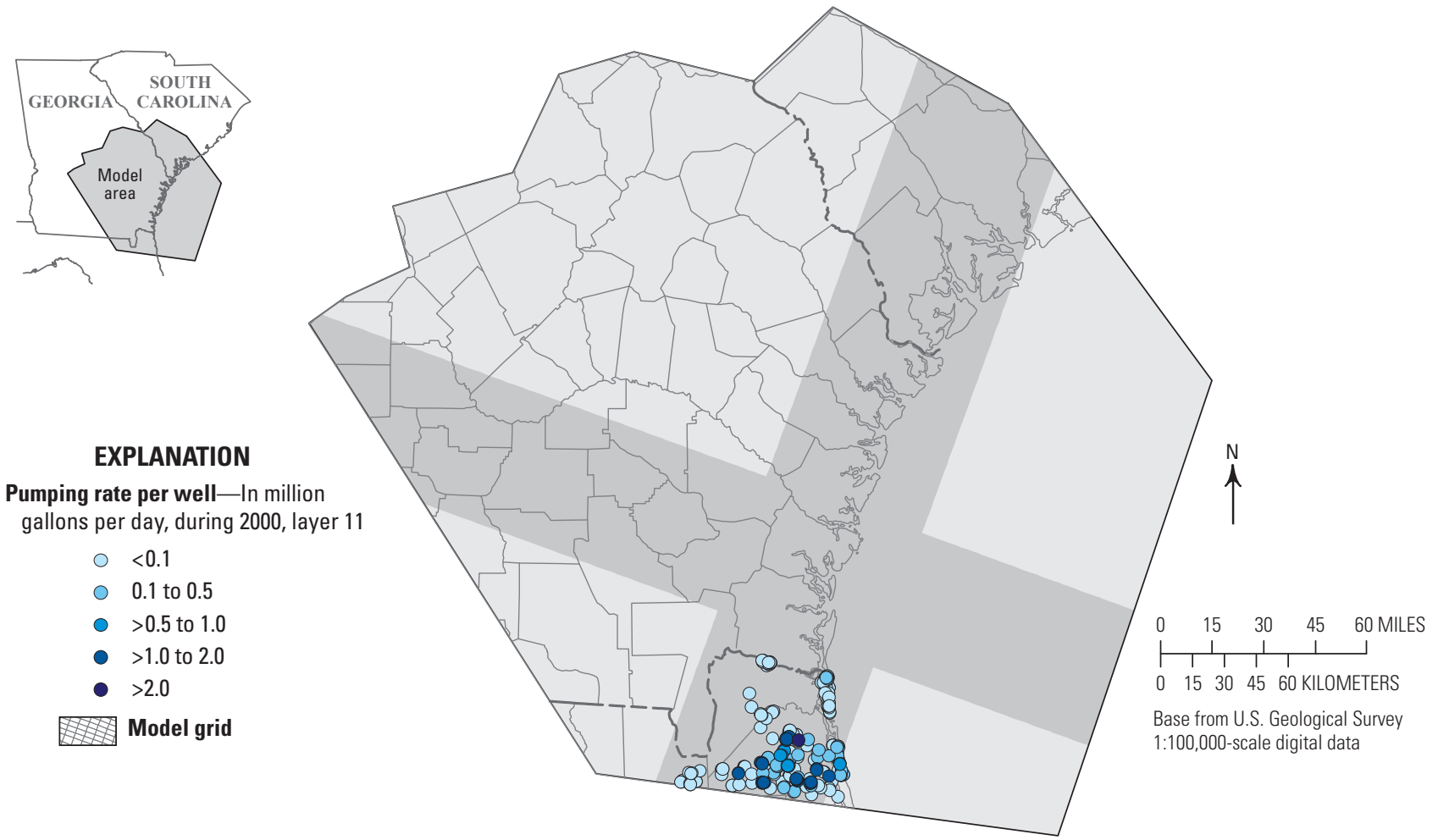

Figure 12. Distribution of groundwater pumpage for 2004. for $A$, model layer 3 , upper Brunswick aquifer; $B$, model layer 5 , lower Brunswick aquifer; $C$, model layer 7 , Upper Floridan aquifer upper water-bearing zone; $D$, model layer 9 , Upper Floridan aquifer lower water-bearing zone; and $E$, model layer 11, Lower Floridan aquifer-Continued

Parameter-estimation techniques were used to adjust hydraulic properties in an efficient manner that (1) eliminated the need for time-intensive, trial-and-error, manual techniques of achieving calibration and (2) resulted in a distribution of hydraulic conductivity that nearly satisfied the calibration criterion of matching simulated to observed groundwater levels. Minor adjustments were made to the parameter estimation results to obtain a calibrated model of steady-state 2004 conditions. The calibrated model then simulated steady-state 2000 pumping and boundary conditions.

\section{Acceptance Criteria}

Model performance for 2000 and 2004 conditions was evaluated on the basis of differences (residuals) between simulated and observed water levels as well as their corresponding mean, median, and root-mean-square-error (RMSE) statistics (tables 5 and 6). The mean residual is a good indicator of bias in the differences between observed and simulated heads. The median residual eliminates the bias in the data and is more robust than the mean in the presence of outlier values. RMSE, derived from residuals as the square root of the average deviation of the residuals from zero, yields a measure of overall fit of simulated to observed groundwater levels. The calibration criteria used near the Brunswick/Glynn County area in the revised model were more stringent than those used in the original model because of the relatively low topographic relief in the area and the availability of 5-ft contour intervals on local topographic maps. For altitudes determined from topographic maps near the downtown Brunswick area, one-half the contour interval $(2.5 \mathrm{ft})$ is considered to be the accuracy of well data, including groundwater-level measurements, formation altitudes, and so forth. Generally, the vertical accuracy of land-surface altitude is about $1 \mathrm{ft}$ if the well location has been surveyed or global-positioning instrumentation has been utilized. The observation accuracy, therefore, is the assumed accuracy of water-level observations at a well and was determined to be $4.6 \mathrm{ft}$ for 2000 water-level conditions used in the original model. The original model considered the accuracy of land-surface altitude and seasonal variability in water levels to have the largest influence on observation accuracy. Additional errors inherent to observations (Kuniansky and others, 2003) imply that a calibration criterion of twice the standard deviation of observational accuracy, or $9.2 \mathrm{ft}$ for the 2000 waterlevel conditions, is reasonable. Therefore, the calibration criterion was rounded to $10 \mathrm{ft}$ for the original model. For the revised model, the calibration target for the 2000 and 2004 simulations was $10 \mathrm{ft}$ for areas outside Glynn County and $5 \mathrm{ft}$ near downtown Brunswick. The primary objective of the calibration was to achieve the best possible match of simulated groundwater levels to observed values in the UWBZ of the UFA near the Brunswick/Glynn County area Few observations were available for calibration of the Brunswick aquifer system, LWBZ of the UFA, and the LFA. 
Table 5. Calibration statistics for simulated heads for 2000 conditions.

[UWBZ, upper water-bearing zone; LWBZ, lower water-bearing zone; residual equals simulated minus observed head; - , not calculated because less than 10 values]

\begin{tabular}{|c|c|c|c|c|c|}
\hline Calibration statistic & $\begin{array}{c}\text { Upper } \\
\text { Brunswick } \\
\text { aquifer } \\
\text { (layer 3) } \\
\end{array}$ & $\begin{array}{l}\text { Lower } \\
\text { Brunswick } \\
\text { aquifer } \\
\text { (layer 5) }\end{array}$ & $\begin{array}{l}\text { UWBZ of } \\
\text { Upper Floridan } \\
\text { aquifer } \\
\text { (layer 7) }\end{array}$ & $\begin{array}{l}\text { LWBZ of } \\
\text { Upper Floridan } \\
\text { aquifer } \\
\text { (layer 9) }\end{array}$ & $\begin{array}{l}\text { Lower } \\
\text { Floridan } \\
\text { aquifer } \\
\text { (layer 11) }\end{array}$ \\
\hline \multicolumn{6}{|c|}{ Regional model area } \\
\hline Number of observations & 7 & 3 & 155 & 5 & 11 \\
\hline Range of observations (feet) & 30.2 & 38.3 & 319 & 34.2 & 142 \\
\hline Maximum negative residual (feet) & -8.82 & -3.18 & -19.5 & -10.0 & -6.10 \\
\hline Maximum positive residual (feet) & 12.8 & 15.5 & 52.0 & 13.1 & 32.4 \\
\hline Mean residual (feet) & -1.39 & 5.66 & 0.92 & -4.57 & 3.72 \\
\hline Median residual (feet) & -2.00 & 4.67 & -0.76 & -8.62 & 0.47 \\
\hline $\begin{array}{l}\text { Root-mean square error residual } \\
\text { (feet) }\end{array}$ & - & - & 10.9 & - & 11.4 \\
\hline $\begin{array}{l}\text { Residuals within } 10 \text {-foot } \\
\text { error criteria (percent) }\end{array}$ & 86 & 67 & 77 & 40 & 82 \\
\hline $\begin{array}{l}\text { Residuals within 5-foot } \\
\text { error criteria (percent) }\end{array}$ & 43 & 67 & 53 & 0 & 64 \\
\hline \multicolumn{6}{|c|}{ Glynn County } \\
\hline Number of observations & 2 & 1 & 41 & 5 & 7 \\
\hline Range of observations (feet) & 8.48 & - & 40.1 & 34.2 & 18.3 \\
\hline Maximum negative residual (feet) & -6.01 & - & -19.5 & -10.0 & -6.10 \\
\hline Maximum positive residual (feet) & 2.69 & - & 4.29 & 13.1 & 9.38 \\
\hline Mean residual (feet) & -1.66 & - & -1.30 & -4.57 & -0.42 \\
\hline Median residual (feet) & - & - & -0.35 & -8.62 & -1.93 \\
\hline $\begin{array}{l}\text { Root-mean square error residual } \\
\text { (feet) }\end{array}$ & - & - & 4.32 & - & - \\
\hline $\begin{array}{l}\text { Residuals within } 10 \text {-foot } \\
\text { error criteria (percent) }\end{array}$ & 100 & 100 & 95 & 40 & 100 \\
\hline $\begin{array}{l}\text { Residuals within 5-foot } \\
\text { error criteria (percent) }\end{array}$ & 50 & 100 & 88 & 0 & 71 \\
\hline
\end{tabular}


Table 6. Calibration statistics for simulated heads for 2004 conditions.

[UWBZ, upper water-bearing zone; LWBZ, lower water-bearing zone; residual equals simulated minus observed head; —, not calculated because less than 10 values]

\begin{tabular}{|c|c|c|c|c|c|}
\hline Calibration statistic & $\begin{array}{l}\text { Upper } \\
\text { Brunswick } \\
\text { aquifer } \\
\text { (layer 3) }\end{array}$ & $\begin{array}{l}\text { Lower } \\
\text { Brunswick } \\
\text { aquifer } \\
\text { (layer 5) }\end{array}$ & $\begin{array}{l}\text { UWBZ of } \\
\text { Upper Floridan } \\
\text { aquifer } \\
\text { (layer 7) }\end{array}$ & $\begin{array}{l}\text { LWBZ of } \\
\text { Upper Floridan } \\
\text { aquifer } \\
\text { (layer 9) }\end{array}$ & $\begin{array}{l}\text { Lower } \\
\text { Floridan } \\
\text { aquifer } \\
\text { (layer 11) }\end{array}$ \\
\hline \multicolumn{6}{|c|}{ Regional model area } \\
\hline Number of observations & 14 & 4 & 52 & 5 & 13 \\
\hline Range of observations (feet) & 144 & 44.5 & 319 & 34.2 & 91.7 \\
\hline Maximum negative residual (feet) & -28.6 & -12.5 & -18.9 & -6.15 & -37.6 \\
\hline Maximum positive residual (feet) & 9.30 & 10.6 & 18.3 & 20.8 & 24.2 \\
\hline Mean residual (feet) & -5.60 & -3.62 & -2.64 & 1.20 & -3.61 \\
\hline Median residual (feet) & -3.57 & -6.31 & -2.05 & -3.30 & -3.73 \\
\hline $\begin{array}{l}\text { Root-mean square error residual } \\
\text { (feet) }\end{array}$ & 11.6 & - & 6.95 & - & 14.5 \\
\hline $\begin{array}{l}\text { Residuals within } 10 \text {-foot } \\
\text { error criteria (percent) }\end{array}$ & 79 & 50 & 83 & 80 & 54 \\
\hline $\begin{array}{l}\text { Residuals within } 5 \text {-foot } \\
\text { error criteria (percent) }\end{array}$ & 43 & 0 & 60 & 60 & 38 \\
\hline \multicolumn{6}{|c|}{ Glynn County } \\
\hline Number of observations & 6 & 2 & 32 & 5 & 7 \\
\hline Range of observations (feet) & 33.8 & 13.6 & 42.9 & 34.2 & 12.1 \\
\hline Maximum negative residual (feet) & -13.7 & -12.5 & -18.9 & -6.15 & -10.9 \\
\hline Maximum positive residual (feet) & 9.30 & -6.26 & 3.98 & 20.8 & 1.98 \\
\hline Mean residual (feet) & -0.77 & -9.38 & -2.56 & 1.20 & -4.50 \\
\hline Median residual (feet) & -0.66 & - & -1.50 & -3.30 & -3.73 \\
\hline $\begin{array}{l}\text { Root-mean square error residual } \\
\text { (feet) }\end{array}$ & - & - & 5.34 & - & - \\
\hline $\begin{array}{l}\text { Residuals within } 10 \text {-foot } \\
\text { error criteria (percent) }\end{array}$ & 83 & 50 & 91 & 80 & 86 \\
\hline $\begin{array}{l}\text { Residuals within } 5 \text {-foot } \\
\text { error criteria (percent) }\end{array}$ & 67 & 0 & 75 & 60 & 71 \\
\hline
\end{tabular}




\section{Year 2000 Calibration}

Groundwater levels measured in 181 wells during 2000 (fig. 13A; table 5) were used to determine the acceptance of simulated groundwater levels as a criterion for calibrating the revised model. Of these 181 measurements, 7 were derived from the upper Brunswick aquifer (layer 3), 3 were from the lower Brunswick aquifer (layer 5), 155 were from the UWBZ of the UFA (layer 7), 5 were from the LWBZ of the UFA (layer 9), and 11 were from the LFA (layer 11).

Over the regional model area, residuals, or simulated minus observed water-level altitudes, calculated for 155 wells tapping the UWBZ of the UFA (layer 7) ranged from -19.5 to $52.0 \mathrm{ft}$, with a mean of $0.92 \mathrm{ft}$, a median of $-0.76 \mathrm{ft}$, and an RMSE of $10.9 \mathrm{ft}$ (fig. 13A; table 5). In the Brunswick/Glynn County area, the mean residual based on 41 measured groundwater levels was $-1.30 \mathrm{ft}$, with a median value of $-0.35 \mathrm{ft}$, and an RMSE of $4.32 \mathrm{ft}$ (fig. 13B).

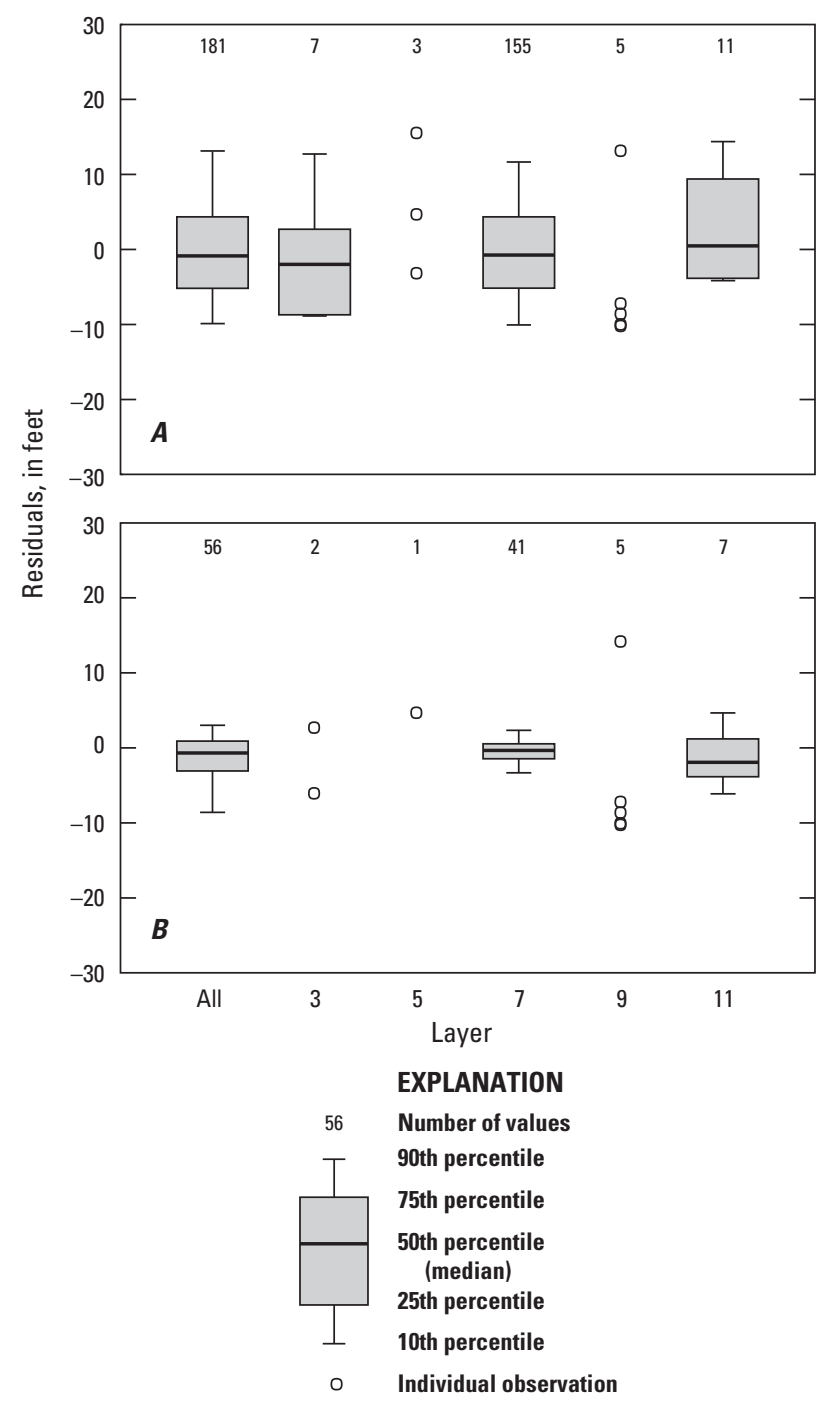

Figure 13. Boxplots showing difference (residuals) between simulated and observed heads for 2000 simulation in $A$, the regional model area and $B$, Brunswick/Glynn County area.
Residuals in the LWBZ of the UFA (layer 9) were derived from 5 observations and ranged from -10.0 to $13.1 \mathrm{ft}$ with a mean residual of $-4.57 \mathrm{ft}$ and median residual of $-8.62 \mathrm{ft}$, indicating poor model performance in the Brunswick/Glynn County area (fig. 13B; table 5). Mean residuals for the LFA (layer 11) were larger, with $3.72 \mathrm{ft}$ for the regional model area and $-0.42 \mathrm{ft}$ in the Brunswick/Glynn County area, which was considered acceptable. This disparity was also evident in the median value of $0.47 \mathrm{ft}$ for the regional model area versus $-1.93 \mathrm{ft}$ in the Brunswick/Glynn County area (fig.13A-B).

The maps shown in figure $14 A-B$ indicate observation data were sparse for model layers 3 and 5, with the maximum residuals either located near the edge of model boundaries or near the cone of depression in Chatham County. The spatial distribution of the observation data and the influence of pumping in the Chatham County area did not allow adjustments to hydraulic conductivity that would provide a better fit. In the Brunswick/Glynn County area, groundwater-flow directions in model layers 3 and 5 were generally from west to east with a maximum residual of $2.69 \mathrm{ft}$ and a minimum of $-6.01 \mathrm{ft}$ (fig. 14A-B; table 5).

Maps showing simulated 2000 potentiometric surfaces and water-level residuals by model layer: $A$, layer 3 , upper Brunswick aquifer, model area; $B$, layer 5, lower Brunswick aquifer, model area; $C$, layer 7 , upper water-bearing zone of the Upper Floridan aquifer, model area; $D$, layer 9, lower water-bearing zone of the Upper Floridan aquifer; $E$, layer 7, upper water-bearing zone of the Upper Floridan aquifer, Glynn County and Brunswick area enlargement; and $F$, layer 11, Lower Floridan aquifer, model area. The distribution of residuals for model layer 7 shows generally positive values north of Glynn County and west of the Gulf Trough with a cluster of negative values at wells along the coastal plain of Georgia (fig. 14C), indicative of the model's inability to dissipate higher-than-observed simulated hydraulic head across the Gulf Trough. The increased hydraulic conductivity of the hydraulic property zone representing the Gulf Trough would lower simulated hydraulic head to the north and west of the Gulf Trough and, likewise, increase simulated hydraulic head downgradient of the Gulf Trough to the south and east along the Coastal Plain. The effect of increasing the simulated watertransmitting ability of the Gulf Trough on groundwater-level residuals would simultaneously drive the positive residuals upgradient of the Gulf Trough and the negative residuals downgradient of the Gulf Trough closer to zero, thereby improving calibration. In the Brunswick/Glynn County area, the distribution of residuals in model layer 7 indicates a good match outside the cone of depression, with generally negative residual values on the Brunswick peninsula (fig. 14E; table 5). The mean residual for the 2000 simulation in model layer 7 of $-1.30 \mathrm{ft}$ is generally well within the established error criterion of $5 \mathrm{ft}$, but the lower simulated heads could be caused by an overestimation of pumping in the Brunswick area, insufficient simulated interaquifer leakage from the LFA into the UFA, and (or) adjustments made to the specified-head boundary for the Floridan aquifer system (layers 7-11). The distribution 

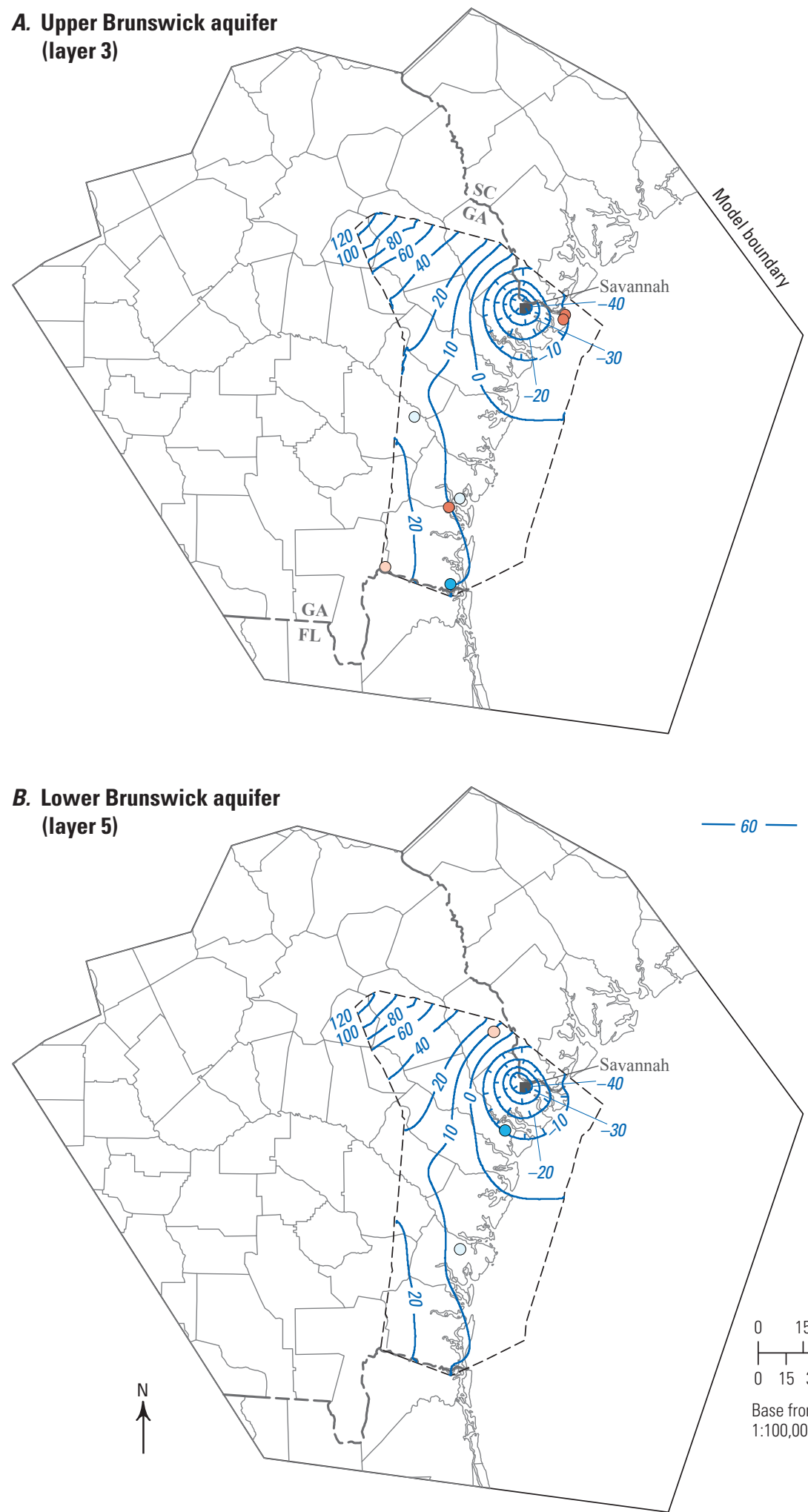

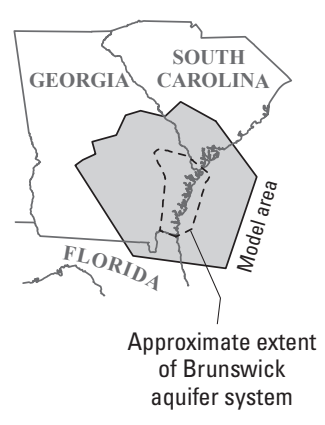

EXPLANATION

- 60 - Simulated potentiometric contourShows simulated 2000 potentiometric surface, in feet. Hachures indicate depression. Contour intervals 10 and 20 feet. Datum is NAVD 88

Water-level residual, in feetRepresents simulated minus observed water levels

- 10 to 20

- 5 to 10

- 0 to 5

○ 0 to -5

- -5 to -10

Figure 14. Simulated 2000 potentiometric surfaces and water-level residuals by model layer: $A$, layer 3 , upper Brunswick aquifer, model area; $B$, layer 5 , lower Brunswick aquifer, model area; $C$, layer 7 , upper water-bearing zone of the Upper Floridan aquifer, model area; $D$, layer 9 , lower water-bearing zone of the Upper Floridan aquifer; $E$, layer 7 , upper waterbearing zone of the Upper Floridan aquifer, Glynn County and Brunswick area enlargement; $F$, layer 9 , lower water-bearing zone of the Upper Floridan aquifer; and G, layer 11, Lower Floridan aquifer, model area and Glynn County enlargement. 

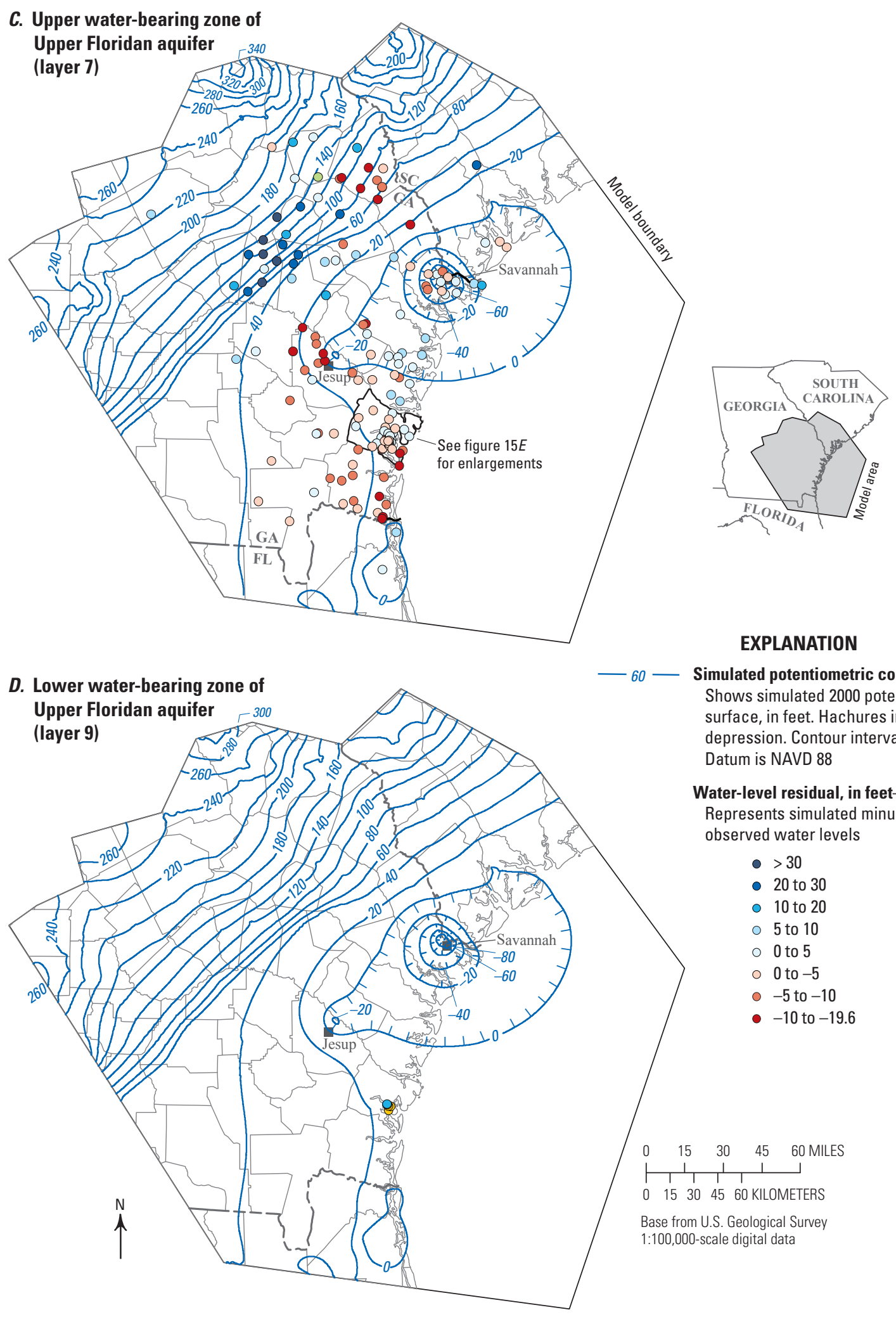

Figure 14. Simulated 2000 potentiometric surfaces and water-level residuals by model layer: $A$, layer 3 , upper Brunswick aquifer, model area; $B$, layer 5, lower Brunswick aquifer, model area; $C$, layer 7, upper water-bearing zone of the Upper Floridan aquifer, model area; $D$, layer 9 , lower water-bearing zone of the Upper Floridan aquifer; $E$, layer 7 , upper water-bearing zone of the Upper Floridan aquifer, Glynn County and Brunswick area enlargement; $F$, layer 9 , lower water-bearing zone of the Upper Floridan aquifer; and $G$, layer 11, Lower Floridan aquifer, model area and Glynn County enlargement.—Continued 


\section{E. Upper water-bearing zone of Upper Floridan aquifer (layer 7)}
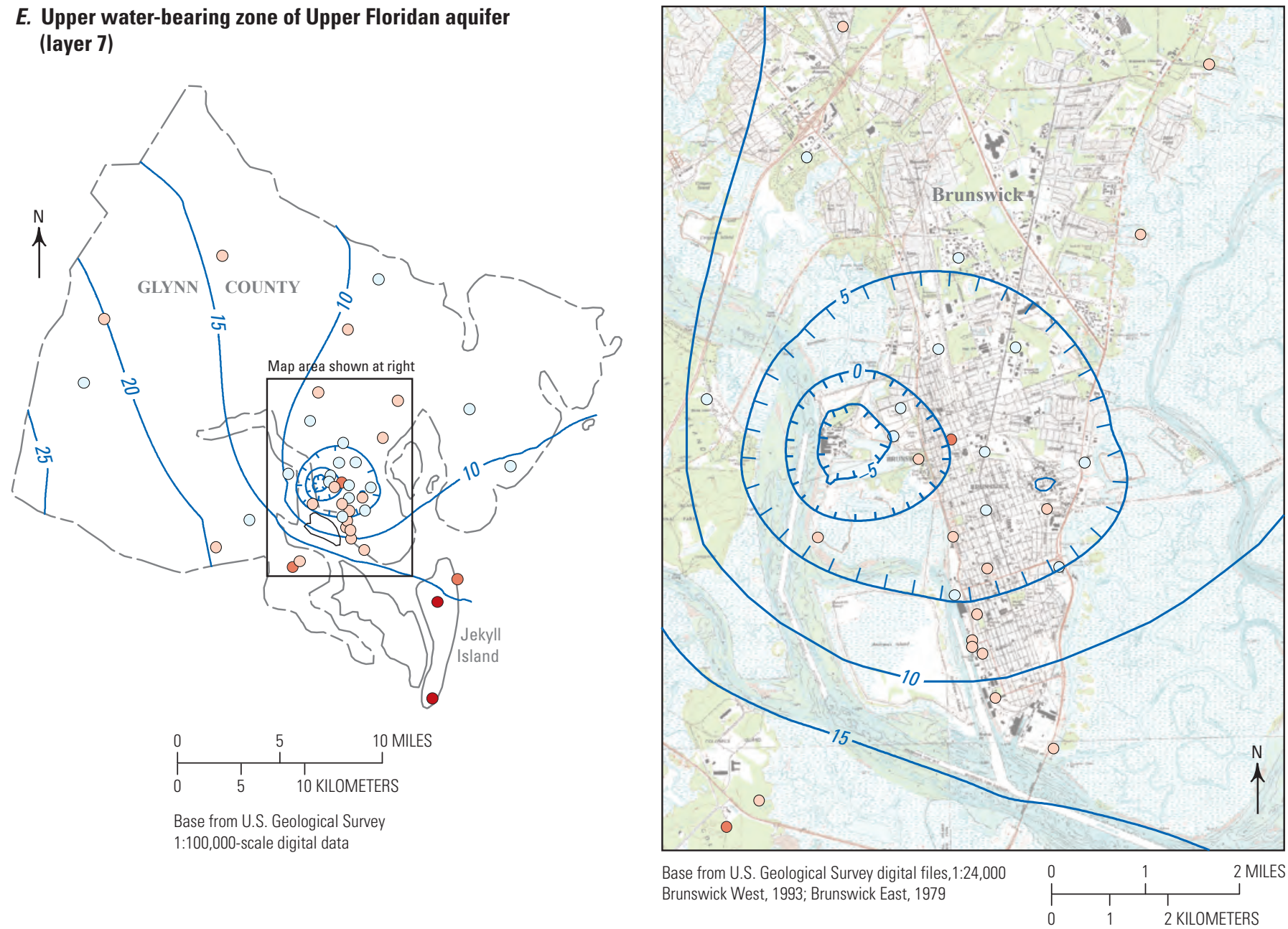

\section{EXPLANATION}

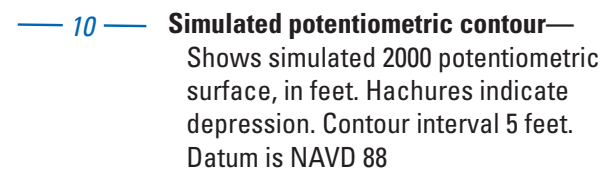

Water-level residual, in feet-Represents simulated minus observed water levels
- 0 to 5
0 to -5
- -5 to -10
- -10 to -19.6

Figure 14. Simulated 2000 potentiometric surfaces and water-level residuals by model layer: $A$, layer 3 , upper Brunswick aquifer, model area; $B$, layer 5 , lower Brunswick aquifer, model area; $C$, layer 7 , upper water-bearing zone of the Upper Floridan aquifer, model area; $D$, layer 9 , lower water-bearing zone of the Upper Floridan aquifer; $E$, layer 7 , upper water-bearing zone of the Upper Floridan aquifer, Glynn County and Brunswick area enlargement; $F$, layer 9, lower water-bearing zone of the Upper Floridan aquifer; and G, layer 11, Lower Floridan aquifer, model area and Glynn County enlargement.-Continued 

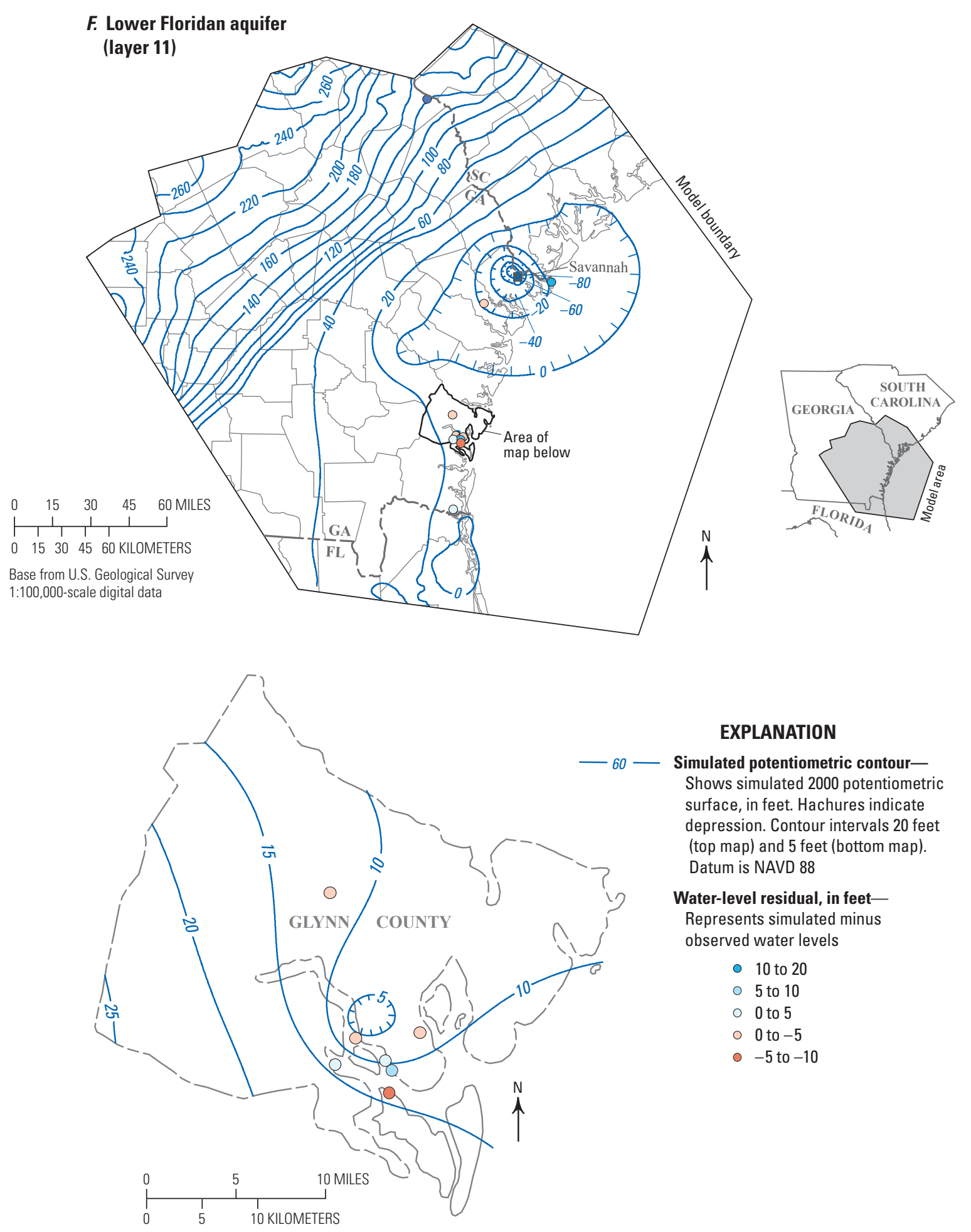

Figure 14. Simulated 2000 potentiometric surfaces and water-level residuals by model layer: $A$, layer 3 , upper Brunswick aquifer, model area; $B$, layer 5, lower Brunswick aquifer, model area; $C$, layer 7 , upper water-bearing zone of the Upper Floridan aquifer, model area; $D$, layer 9 , lower water-bearing zone of the Upper Floridan aquifer; $E$, layer 7, upper water-bearing zone of the Upper Floridan aquifer, Glynn County and Brunswick area enlargement; $F$, layer 9, lower water-bearing zone of the Upper Floridan aquifer; and $G$, layer 11, Lower Floridan aquifer, model area and Glynn County enlargement.-Continued 
of residuals for model layer 11 indicates generally positively skewed residuals in the northern part of the model and negatively skewed residuals to the south of Chatham County. In the Brunswick/Glynn County area, the distribution of residuals in model layer 11 shows mostly negative values near the area of influence for pumping in model layers 7 and 9 near downtown Brunswick with 5 of the 7 wells ( 71 percent) falling within the established 5-ft calibration criterion (fig. 14F).

\section{Year 2004 Calibration}

Groundwater levels measured in 88 wells during 2004 (fig. 15; table 6) were used to determine the acceptance of simulated groundwater levels as a criterion for calibrating the revised model. Of these 88 measurements, 14 were derived from the upper Brunswick aquifer (layer 3), 4 were from the lower Brunswick aquifer (layer 5), 52 were from the UWBZ of the UFA (layer 7), 5 were from the LWBZ of the UFA (layer 9), and 13 were from the LFA (layer 11). For the regional model area, residuals for model layer 7 ranged from -18.9 to $18.3 \mathrm{ft}$, with a mean of $-2.64 \mathrm{ft}$, median of $-2.05 \mathrm{ft}$, and an RMSE of $6.95 \mathrm{ft}$. In the Brunswick/Glynn County area, residuals from 32 observation wells in model layer 7 ranged from -18.9 to $3.98 \mathrm{ft}$, with a mean of $-2.56 \mathrm{ft}$, median of $-1.50 \mathrm{ft}$ and an RMSE of $5.34 \mathrm{ft}$ (fig. 15; table 6). For the regional model area for model layer 3, residuals from 14 observation wells open to the Brunswick aquifer system ranged from -28.6 to $9.30 \mathrm{ft}$, with a mean of $-5.60 \mathrm{ft}$, median of $-3.57 \mathrm{ft}$, and an RMSE of $11.6 \mathrm{ft}$. For model layer 5, residuals from four observation wells ranged from -12.5 to $10.6 \mathrm{ft}$, with a mean of $-3.62 \mathrm{ft}$. For model layer 9, residuals from five wells located near downtown Brunswick ranged from -6.15 to $20.8 \mathrm{ft}$, with a mean of $1.20 \mathrm{ft}$ and a median of $-3.30 \mathrm{ft}$. Over the entire regional model area for model layer 11, residuals from the 13 observation wells ranged from -37.6 to $24.2 \mathrm{ft}$, with a mean of $-3.61 \mathrm{ft}$, median of $-3.73 \mathrm{ft}$, and an RMSE of $14.5 \mathrm{ft}$. The percentage of residuals within the $10-\mathrm{ft}$ calibration target of observed values over the regional model area was 79 percent for model layer 3 , 50 percent for model layer 5,83 percent for model layer 7 , 80 percent for model layer 9 , and 54 percent for model layer 11 . When the more stringent 5-ft calibration target was applied to residuals in the Brunswick/Glynn County area, the percentage within the target was 75 percent for model layer 7, 60 percent for model layer 9 , and 71 percent for model layer 11 .

For the year 2004 calibration, the map showing distribution of water-level residuals for the upper Brunswick aquifer (layer 3) indicates mostly negative values near the northern extent of the aquifer and in the Brunswick/Glynn County area except for several positive values located in northern Glynn County (fig. 16A). Water-level residuals for the lower Brunswick aquifer (layer 5) are negative, except for one positive value located in Bryan County (fig. 16B). Residuals for the UWBZ of the UFA (layer 7) are negative south of the Brunswick/Glynn County area and positive near the Gulf Trough and on the outer edge of the cone of depression in the Savannah area (fig. 16C). In the Brunswick/Glynn County area, the distribution of water-level residuals in the UWBZ

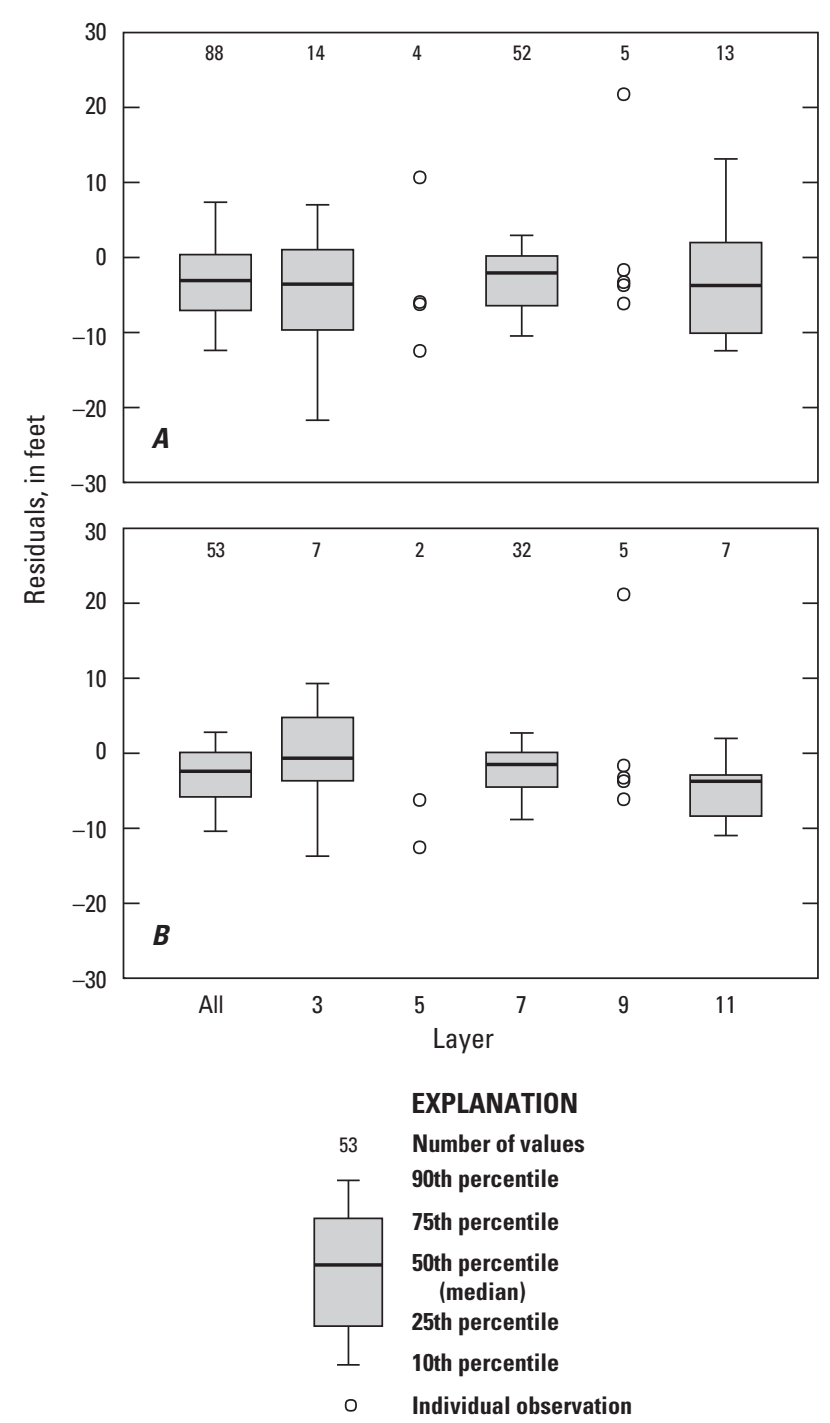

Figure 15. Boxplots showing difference (residuals) between simulated and observed heads for 2004 simulation in the $A$, regional model area, and $B$, Brunswick/Glynn County area.

of the UFA (layer 7) indicates a "good" match, with a mean residual of $-2.56 \mathrm{ft}$ and 75 percent of the values within the established error criterion of $5 \mathrm{ft}$ (fig. $16 E$; table 6). However, the map showing the distribution of water-level residuals indicates an "excellent" match in the downtown Brunswick area but large negative values for wells located on Jekyll Island between the 15 - and 20 -ft simulated potentiometric contours. The map showing the distribution of water-level residuals for the LWBZ of the UFA (layer 9) includes 1 positive value and 4 negative values located south of and near the cone of depression, with a mean residual of $1.20 \mathrm{ft}$ (fig. $16 F$; table 6). The map showing distribution of water-level residuals for the LFA (layer 11) indicates values are negatively skewed, except for several positive values in the Brunswick/Glynn County area and three others located within the cone of depression to the north (fig. 16G; table 6). 


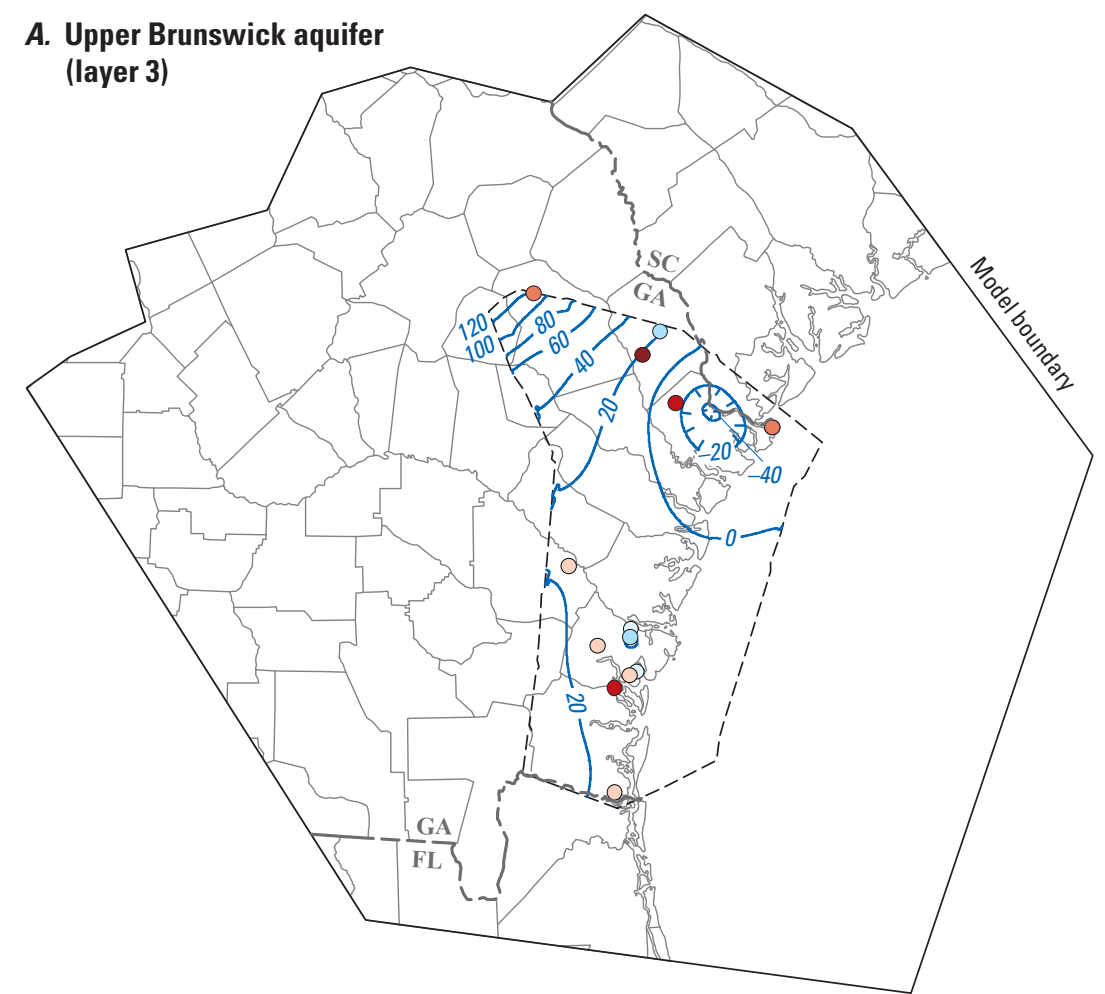

B. Lower Brunswick aquifer B. Lower B
(layer 5)

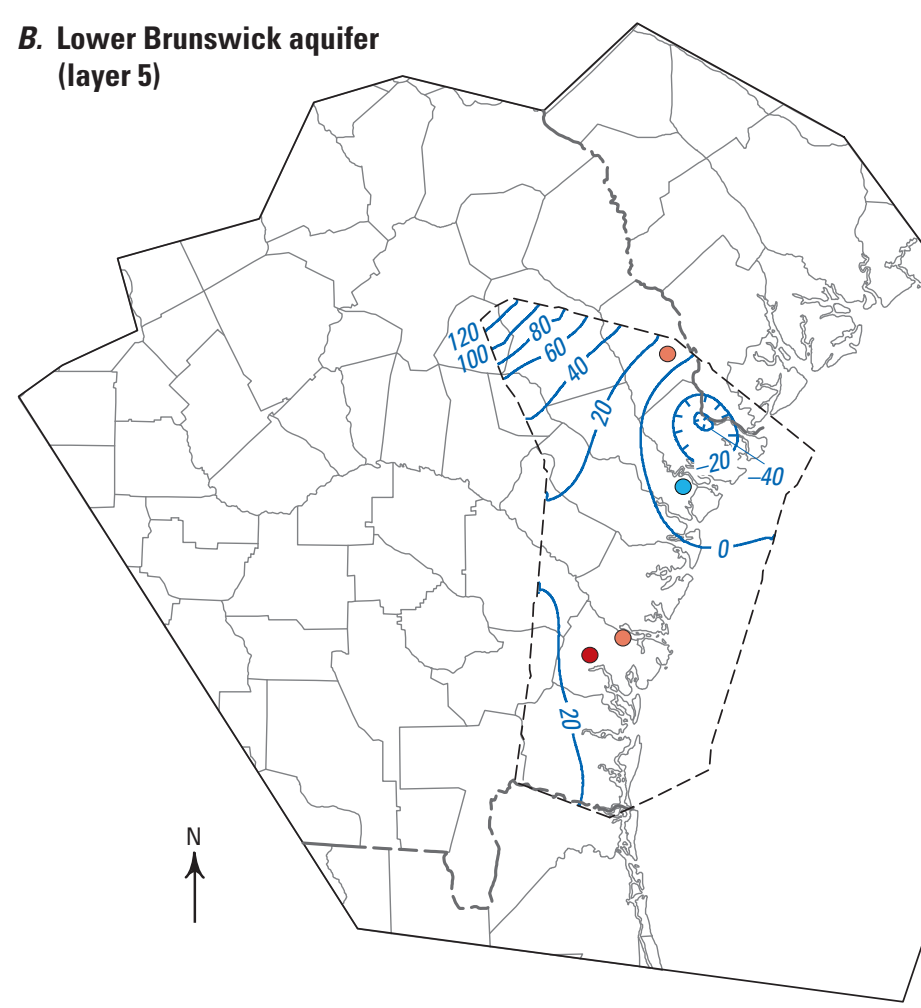

\section{EXPLANATION}

Simulated potentiometric contourShows simulated 2004 potentiometric surface, in feet. Hachures indicate depression. Contour interval 20 feet. Datum is NAVD 88

Water-level residual, in feetRepresents simulated minus observed water levels

- 10 to 20

- 5 to 10

○ 0 to 5

○ 0 to -5

- -5 to -10

- -10 to -20

- -20 to -30

Figure 16. Simulated 2004 potentiometric surfaces and water-level residuals by model layer: $A$, layer 3 , upper Brunswick aquifer, model area; $B$, layer 5 , lower Brunswick aquifer, model area; $C$, layer 7 , upper water-bearing zone of the Upper Floridan aquifer, model area; $D$, layer 9 , lower water-bearing zone of the Upper Floridan aquifer; $E$, layer 7 , upper waterbearing zone of the Upper Floridan aquifer, Glynn County and Brunswick area enlargement; $F$, layer 9 , lower water-bearing zone of the Upper Floridan aquifer; and $G$, layer 11, Lower Floridan aquifer, model area and Glynn County enlargement. 

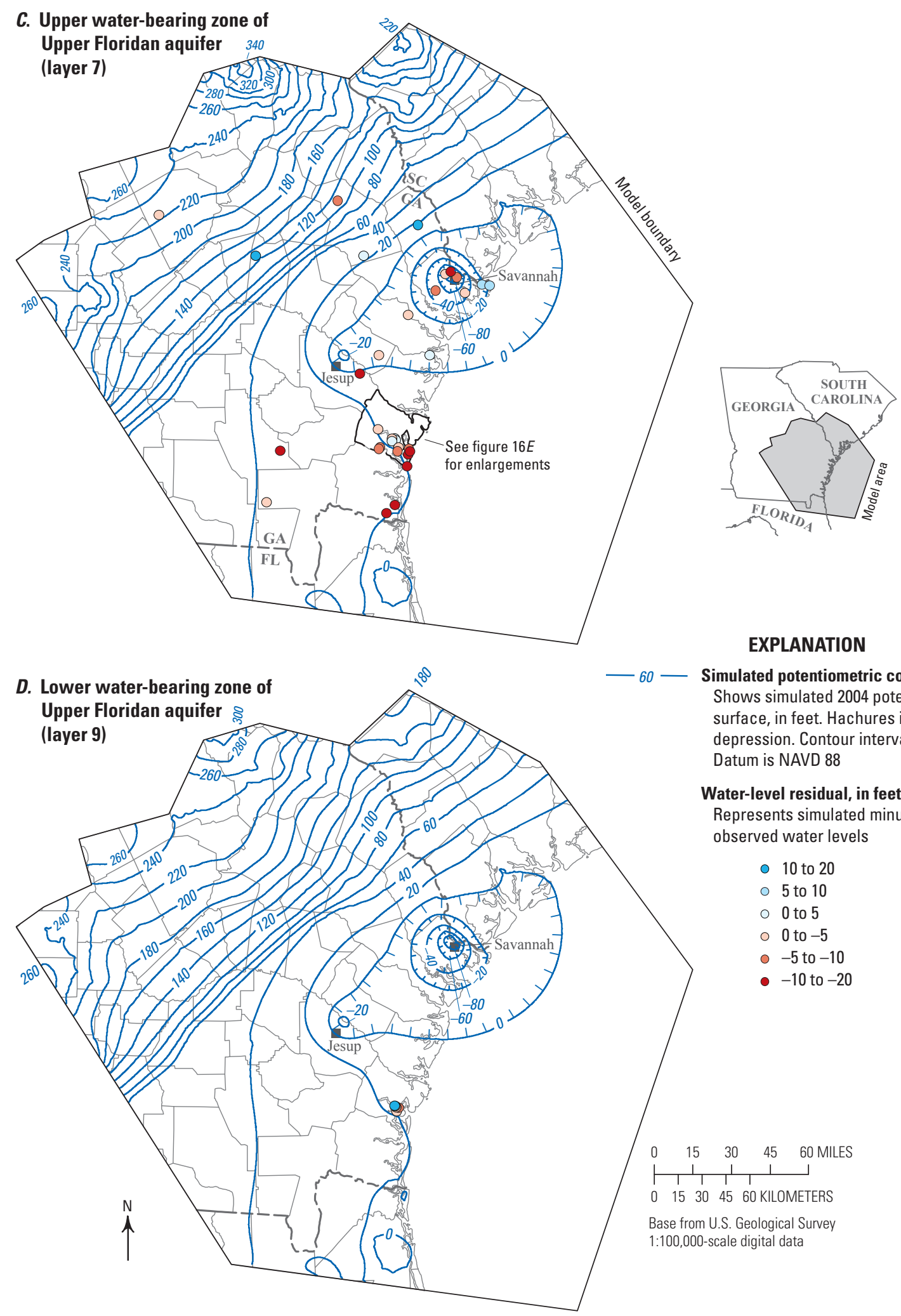

Figure 16. Simulated 2004 potentiometric surfaces and water-level residuals by model layer: $A$, layer 3 , upper Brunswick aquifer, model area; $B$, layer 5 , lower Brunswick aquifer, model area; $C$, layer 7 , upper water-bearing zone of the Upper Floridan aquifer, model area; $D$, layer 9 , lower water-bearing zone of the Upper Floridan aquifer; $E$, layer 7 , upper water-bearing zone of the Upper Floridan aquifer, Glynn County and Brunswick area enlargement; $F$, layer 9, lower water-bearing zone of the Upper Floridan aquifer; and $G$, layer 11, Lower Floridan aquifer, model area and Glynn County enlargement.-Continued 


\section{E. Upper water-bearing zone of Upper Floridan aquifer} (layer 7)
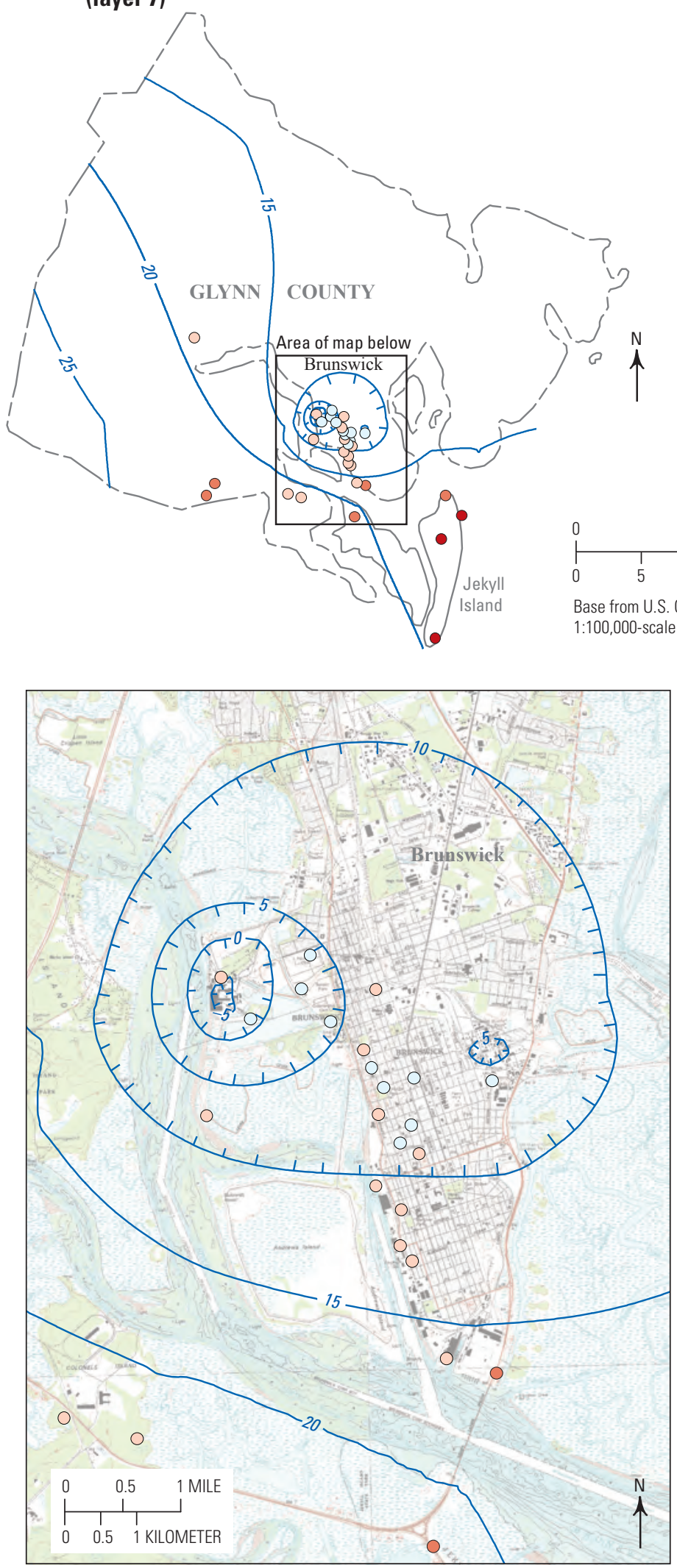

Base from U.S. Geological Survey digital files,1:24,000, Brunswick West, 1993; Brunswick East, 1979

\section{F. Lower water-bearing zone of Upper Floridan aquifer} (layer 9)

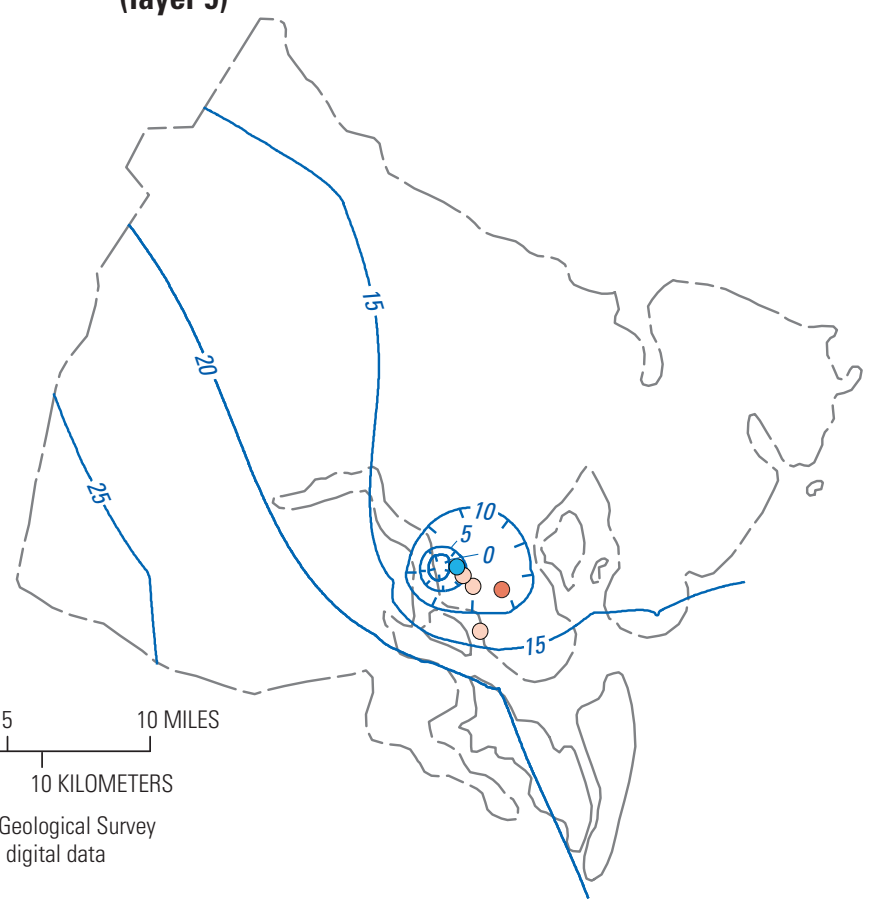

\section{EXPLANATION}

- 10 - Simulated potentiometric contour-

Shows simulated 2004 potentiometric surface, in feet. Hachures indicate depression. Contour interval 5 feet. Datum is NAVD 88

Water-level residual, in feetRepresents simulated minus observed water levels

$$
\begin{array}{ll}
\text { 10 } & 10 \text { to } 20 \\
5 & 5 \text { to } 10 \\
0 & \text { to } 5 \\
0 & 0 \text { to }-5 \\
0 & -5 \text { to }-10 \\
- & -10 \text { to }-20
\end{array}
$$

Figure 16. Simulated 2004 potentiometric surfaces and water-level residuals by model layer: $A$, layer 3, upper Brunswick aquifer, model area; $B$, layer 5 , lower Brunswick aquifer, model area; $C$, layer 7 , upper water-bearing zone of the Upper Floridan aquifer, model area; $D$, layer 9 , lower water-bearing zone of the Upper Floridan aquifer; $E$, layer 7, upper water-bearing zone of the Upper Floridan aquifer, Glynn County and Brunswick area enlargement; $F$, layer 9 , lower waterbearing zone of the Upper Floridan aquifer; and $G$, layer 11, Lower Floridan aquifer, model area and Glynn County enlargement.-Continued 


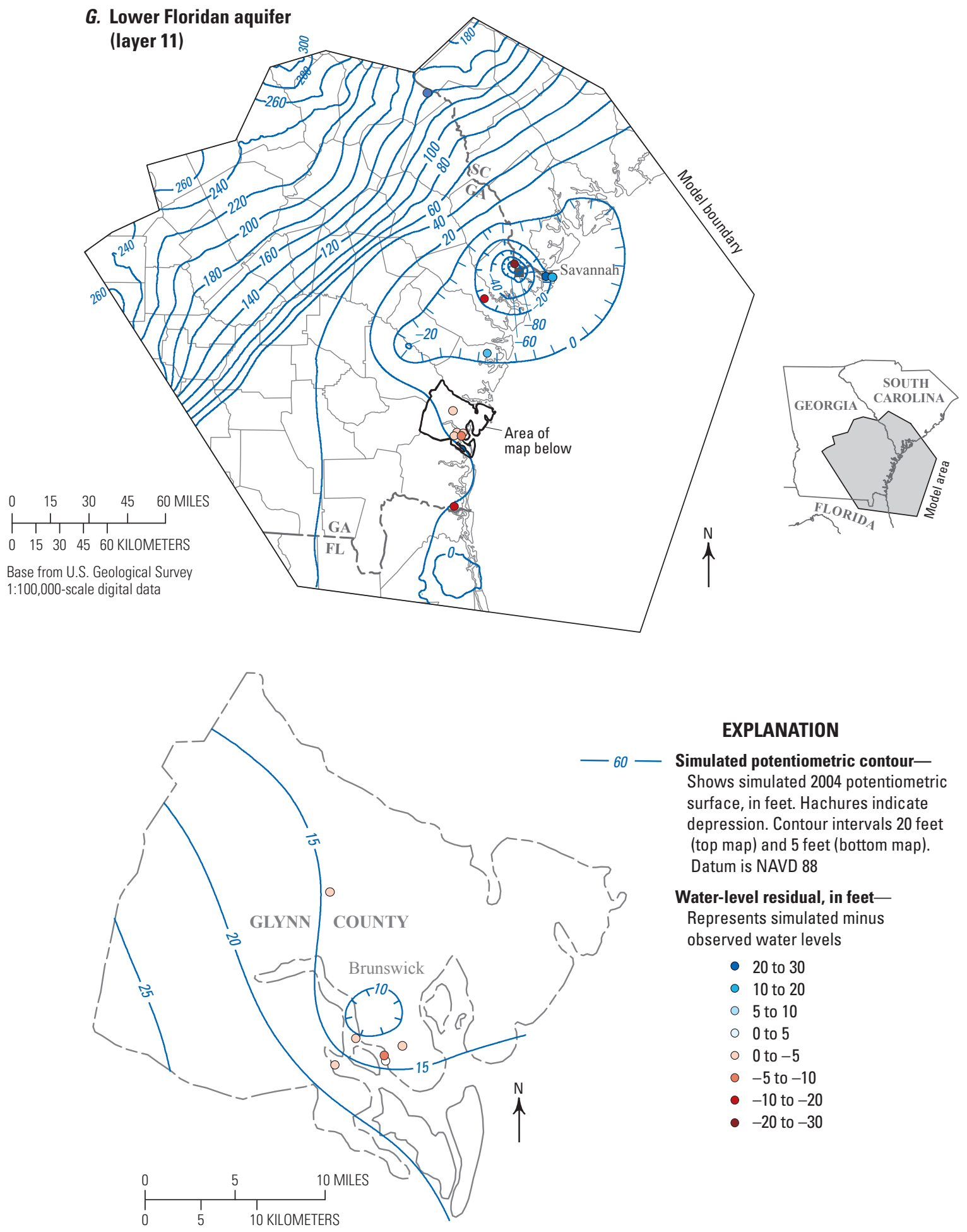

Figure 16. Simulated 2004 potentiometric surfaces and water-level residuals by model layer: $A$, layer 3 , upper Brunswick aquifer, model area; $B$, layer 5 , lower Brunswick aquifer, model area; $C$, layer 7 , upper water-bearing zone of the Upper Floridan aquifer, model area; $D$, layer 9, lower water-bearing zone of the Upper Floridan aquifer; $E$, layer 7, upper water-bearing zone of the Upper Floridan aquifer, Glynn County and Brunswick area enlargement; $F$, layer 9 , lower water-bearing zone of the Upper Floridan aquifer; and $G$, layer 11, Lower Floridan aquifer, model area and Glynn County enlargement.-Continued 


\section{Simulated Potentiometric Surfaces}

The steady-state simulated potentiometric surfaces for 2000 and 2004 indicate groundwater flow from upland regions to the north and west toward the coast, where flow converges at pumping centers near Chatham County, Ga., and Brunswick/Glynn County, Ga. The simulated potentiometric surface maps also show impeded groundwater flow, evidenced by steep potentiometric gradients in upland areas north and west of the Gulf Trough and flatter gradients near the coast where the Floridan aquifer system is more productive.

\section{Conditions}

Simulated potentiometric surfaces of the Brunswick aquifer system (layers 3 and 5) for 2000 indicate steep potentiometric gradients, with simulated water-level altitudes ranging from about $120 \mathrm{ft}$ in the northwestern extent of the aquifer system to below $-40 \mathrm{ft}$ near the city of Savannah (fig. 14A-B). The simulated potentiometric contours for the Brunswick aquifer system indicate groundwater-flow patterns similar to those of the Floridan aquifer system (fig. 14F) and influenced by pumping in the underlying aquifer in the Chatham County area. Simulated potentiometric surface maps of the UFA (layers 7 and 9) for 2000 show steep potentiometric gradients in the upland areas north and west of the Gulf Trough, with groundwater flow toward the coast (fig. $14 C-D$ ). South and east of the Gulf Trough, potentiometric gradients flatten and groundwater-flow directions are influenced by a cone of depression centered in the Savannah area, which alters the regional coastward flow pattern. The broad area of influence for this cone of depression is indicated by the 0 - $\mathrm{ft}$ contour, which extends to an area of pumping to the southwest near Jesup, Ga., and north into Jasper and Beaufort Counties, S.C. The simulated water-level altitudes near the center of pumping in Savannah are below $-60 \mathrm{ft}$ in layer 7 and below $-80 \mathrm{ft}$ in layer 9, respectively. In the Brunswick/Glynn County area, potentiometric contours indicate groundwater flow from west to east, with a cone of depression near downtown Brunswick locally altering the coastward flow pattern (fig. 14E). The cone of depression, centered in an active industrial well field, intercepts groundwater flow from the west and south with simulated head altitudes below $-5 \mathrm{ft}$. The simulated potentiometric contour map for 2000 in the LFA (layer 11) indicates groundwater-flow patterns similar to those in the UFA, with a cone of depression influenced by pumping in the overlying layers in the Chatham County area (fig. 14F).

\section{Conditions}

Simulated potentiometric surfaces of the Brunswick aquifer system (layers 3 and 5) for 2004 (fig. 16A-B) indicate groundwater flow from upland areas to the west toward the cone of depression in the Savannah area created by pumping in the underlying UFA. Another groundwater-flow direction parallels the coast from the Brunswick/Glynn County area northward toward the Savannah area. Simulated potentiometric surface maps of the UFA (layers 7 and 9) for 2004 show steep potentiometric gradients in the upland areas north and west of the Gulf Trough, with coastward groundwater flow (fig. 16C-D). Groundwater-flow directions are influenced by a cone of depression centered in the Savannah area that alters the coastward flow pattern. The broad area of influence for this cone of depression is evident by the $0-\mathrm{ft}$ contour, which extends to an area of pumping to the southwest near Jesup, Ga., and north into Jasper and Beaufort Counties, S.C. Simulated potentiometric contours in the Savannah area show water-level altitudes below $-60 \mathrm{ft}$ in layer 7 and below $-80 \mathrm{ft}$ in layer 9, respectively. In the Brunswick/Glynn County area, potentiometric contours indicate groundwater flow from west to east, with a cone of depression near downtown Brunswick locally altering the coastward flow pattern (fig. $16 E-F$ ).

The cone of depression near the active industrial well field intercepts groundwater flow from the west and south, with simulated head altitudes below $-5 \mathrm{ft}$. The simulated potentiometric contour map for 2004 in the LFA (layer 11) indicates groundwater-flow patterns similar to those in the UFA with a cone of depression influenced by pumping in the overlying layers in the Chatham County area (fig. 16G).

\section{Simulated Water-Level Changes, 2000-04}

Steady-state simulations for 2000 and 2004 were compared for the regional model area by computing waterlevel changes, which indicated water-level rises because of a decrease in pumpage from 2000 to 2004. Changes in simulated groundwater levels for the Brunswick aquifer system (layers 3 and 5) were influenced by changes in pumping rates from 2000 to 2004. Simulated water levels (and changes) indicate water-level rises in Glynn County, corresponding to a decrease in pumpage during this period, with the exception of the Brunswick aquifer system (layers 3 and 5), which had an increase in pumping rates from 2000 to 2004 and resulted in a concurrent decrease in water levels. Simulated water levels and changes for 2000 and 2004 agree with water-level increases documented in continuous recording wells $33 \mathrm{H} 133$, 33H127, 34H436, and 33H188 (fig. 17). Simulated water levels and changes in well 34H437 for 2000 and 2004 indicated a decrease of $3.30 \mathrm{ft}$, while continuous water-level data indicated an increase of $3.04 \mathrm{ft}$.

Simulated water-levels declined from 2000 to 2004 in the Brunswick aquifer system (layers 3 and 5) in the Brunswick/Glynn County area in response to increased pumpage. During this period, water levels declined more than $10 \mathrm{ft}$ near activated Golden Isles public-supply wells in northern Glynn County. Water-levels declined more than $5 \mathrm{ft}$ near new golf-course irrigation wells on Jekyll Island in Glynn County (fig. 18A-B). These wells contributed to a 6-fold increase in combined pumpage from the Brunswick aquifer system (layers 3 and 5) during this period, from $0.24 \mathrm{Mgal} / \mathrm{d}$ in 2000 to $1.75 \mathrm{Mgal} / \mathrm{d}$ in 2004 . 
A. Well 34H437—Upper Brunswick aquifer (layer 3)

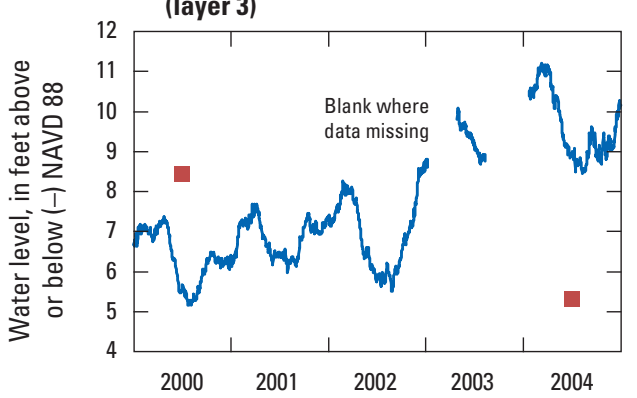

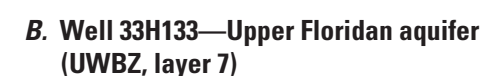
(UWBZ, layer 7)

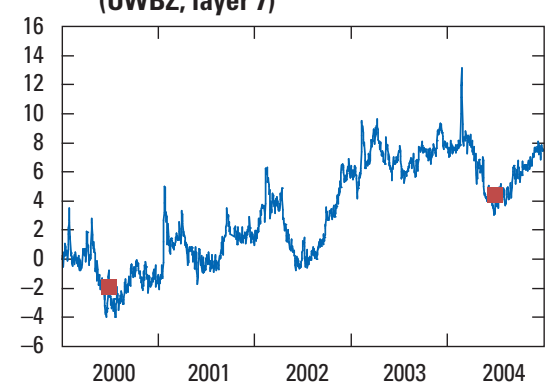

C. Well 33H127-Upper Floridan aquifer (LWBZ, layer 9)

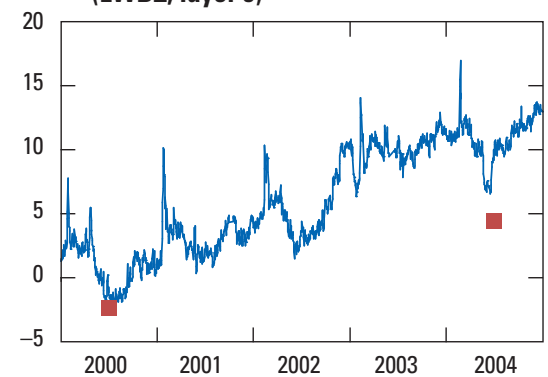

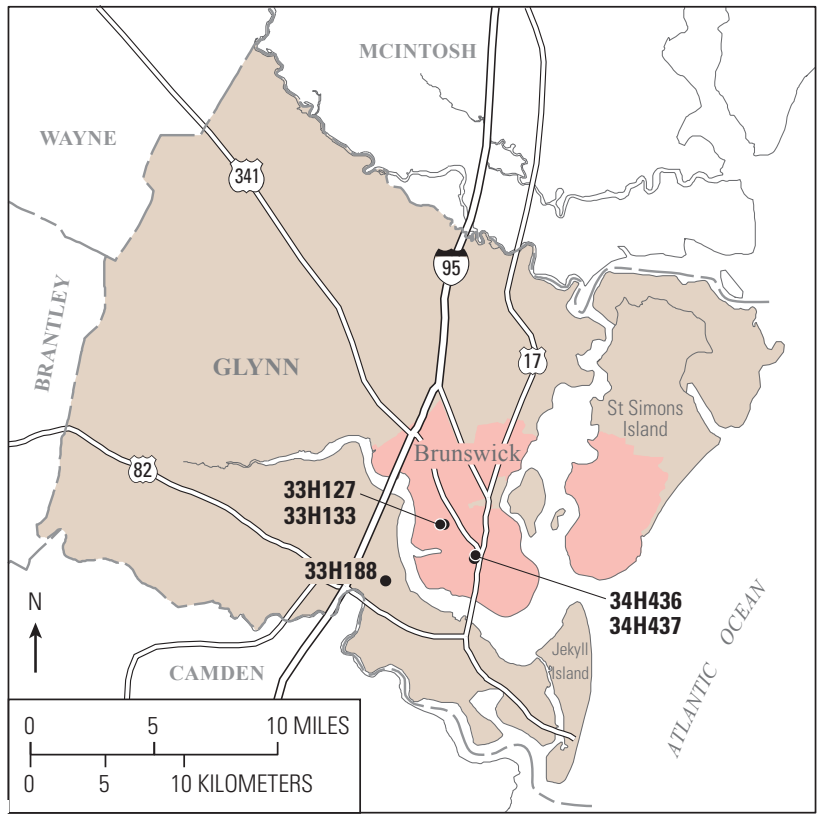

Base modified from U.S. Geological Survey, 1:100,000-scale digital data

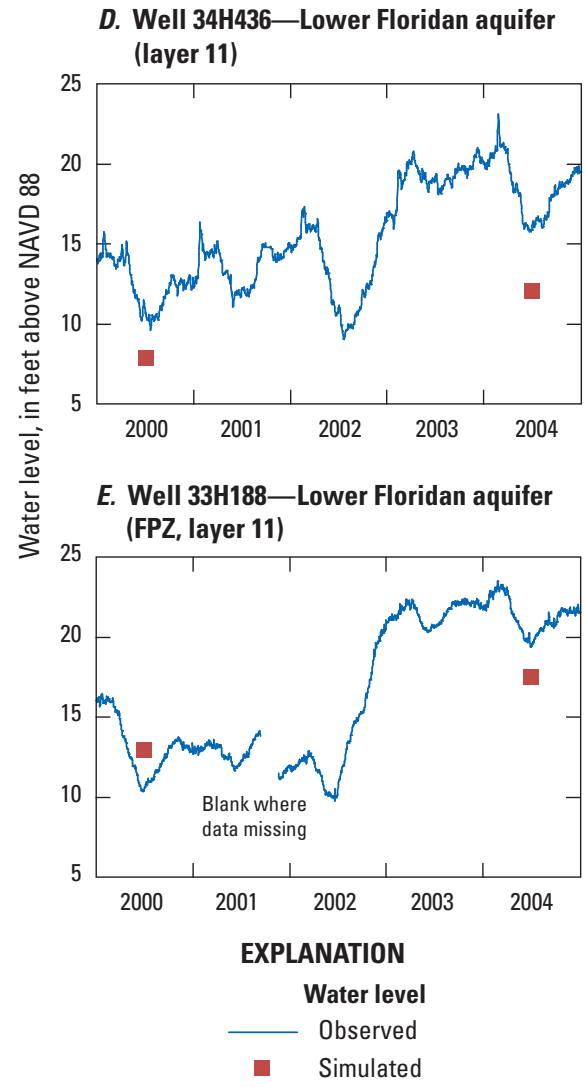

- Well

Figure 17. Hydrographs showing selected water-levels and simulated heads for $A$, upper Brunswick aquifer; $B$, Upper Floridan aquifer upper water-bearing zone (UWBZ); $C$, Upper Floridan aquifer lower water-bearing zone (LWBZ); $D$, Lower Floridan aquifer; and $E$, Lower Floridan aquifer Fernandina permeable zone (FPZ), Glynn County, Georgia, 2000-2004. 

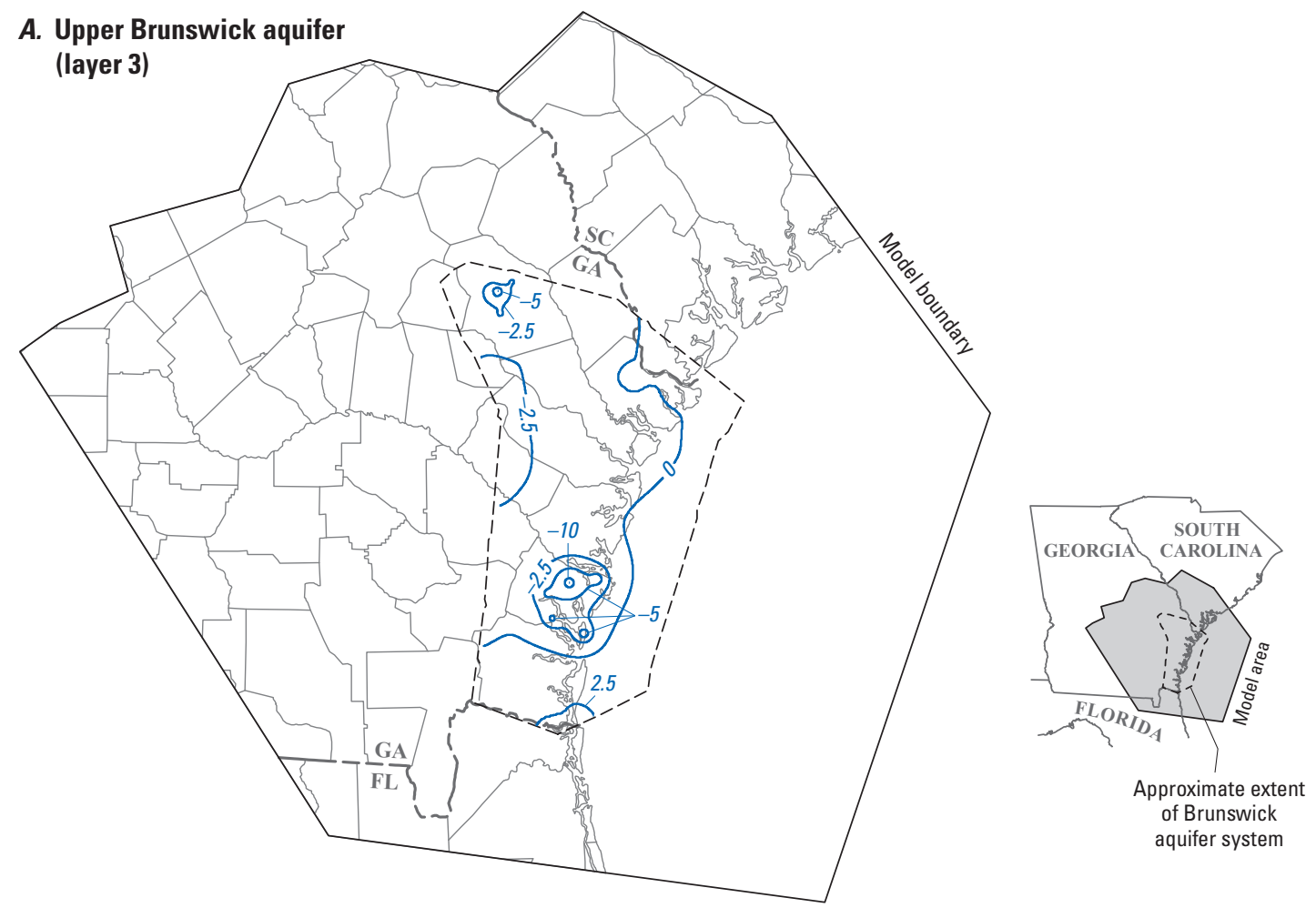

\section{B. Lower Brunswick aquifer}

\section{(layer 5)}
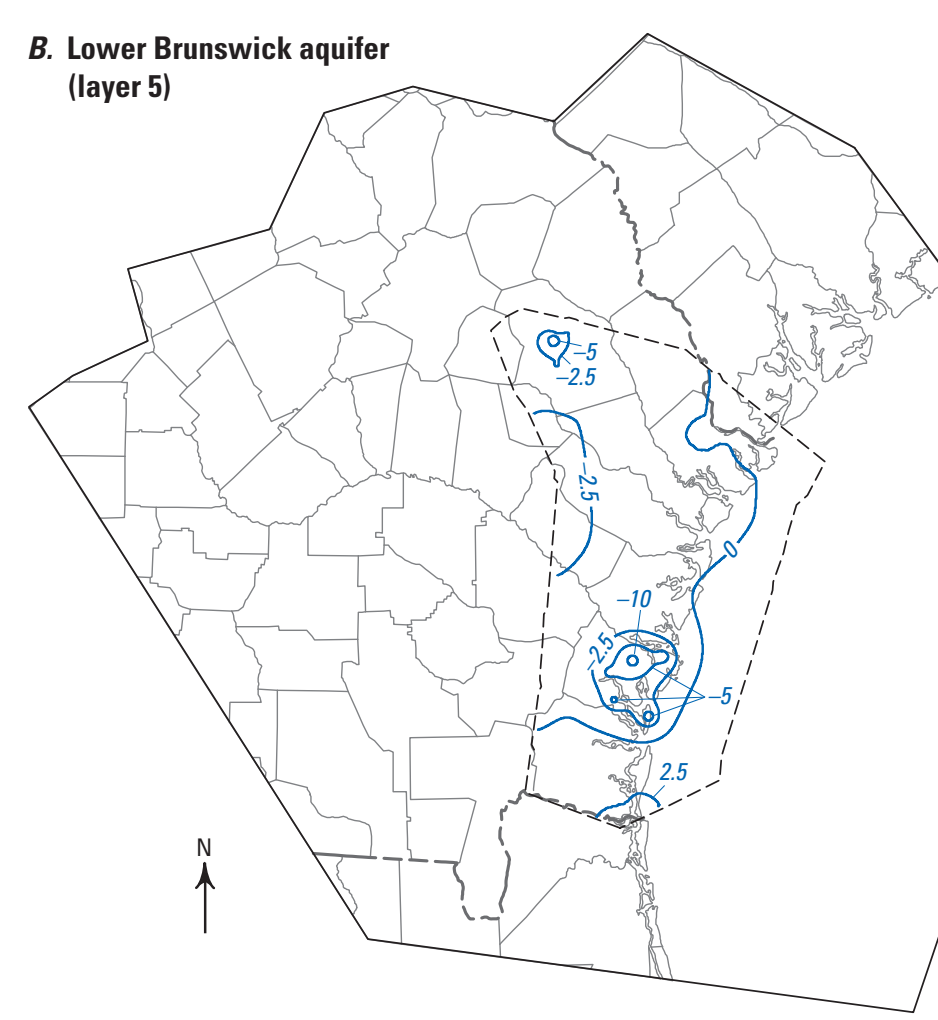

Figure 18. Simulated water-level change from 2000 to 2004 for $A$, model layer 3 , upper Brunswick aquifer, $B$, model layer 5 , lower Brunswick aquifer, $C$, upper water-bearing zone of Upper Floridan aquifer, $D$, lower water-bearing zone of Upper Floridan aquifer, and $E$, Lower Floridan aquifer. 

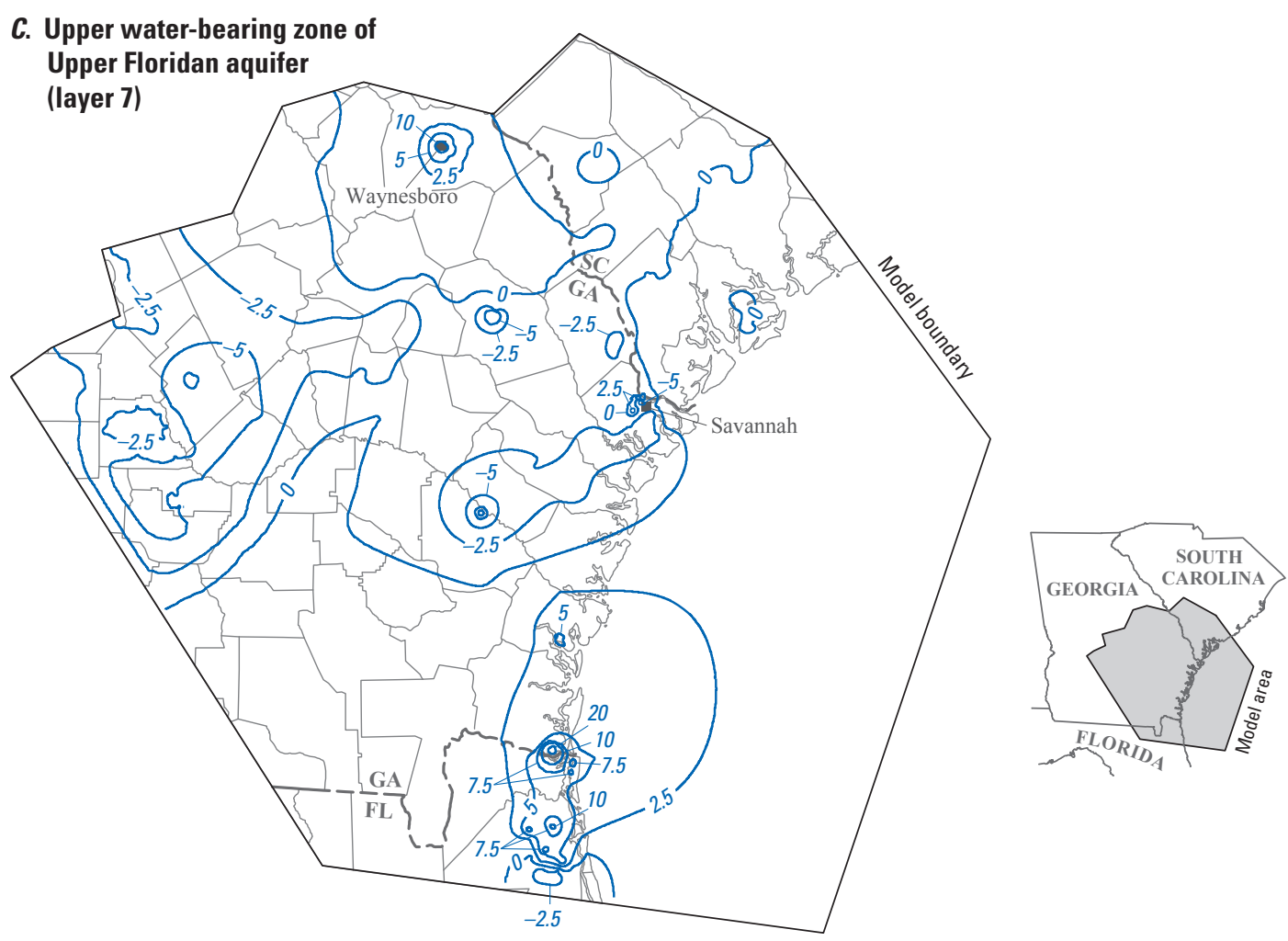

D. Lower water-bearing zone of Upper Floridan aquifer (layer 9)

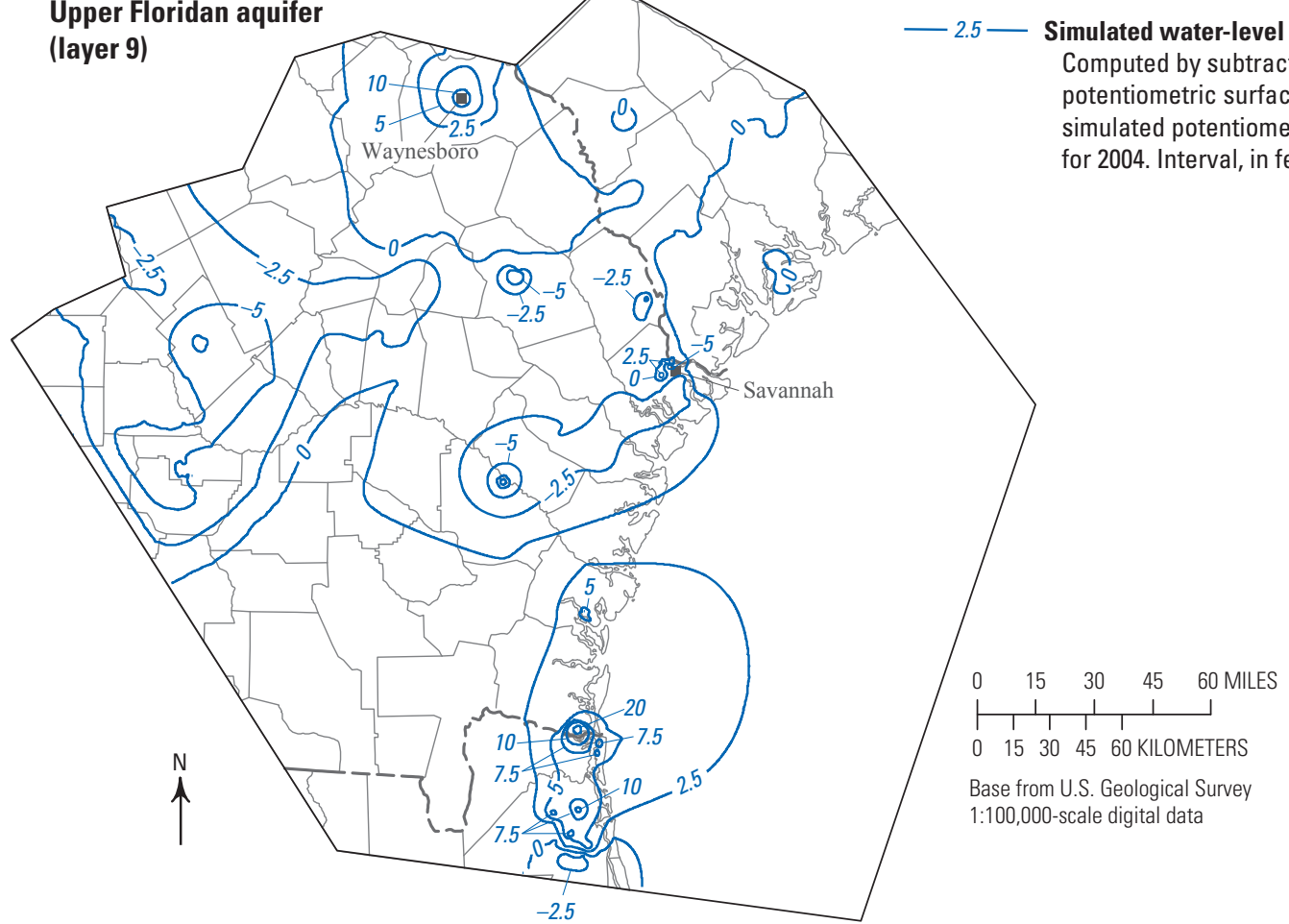

Figure 18. Simulated water-level change from 2000 to 2004 for $A$, model layer 3, upper Brunswick aquifer, $B$, model layer 5 , lower Brunswick aquifer, $C$, upper water-bearing zone of Upper Floridan aquifer, $D$, lower water-bearing zone of Upper Floridan aquifer, and $E$, Lower Floridan aquifer-Continued 


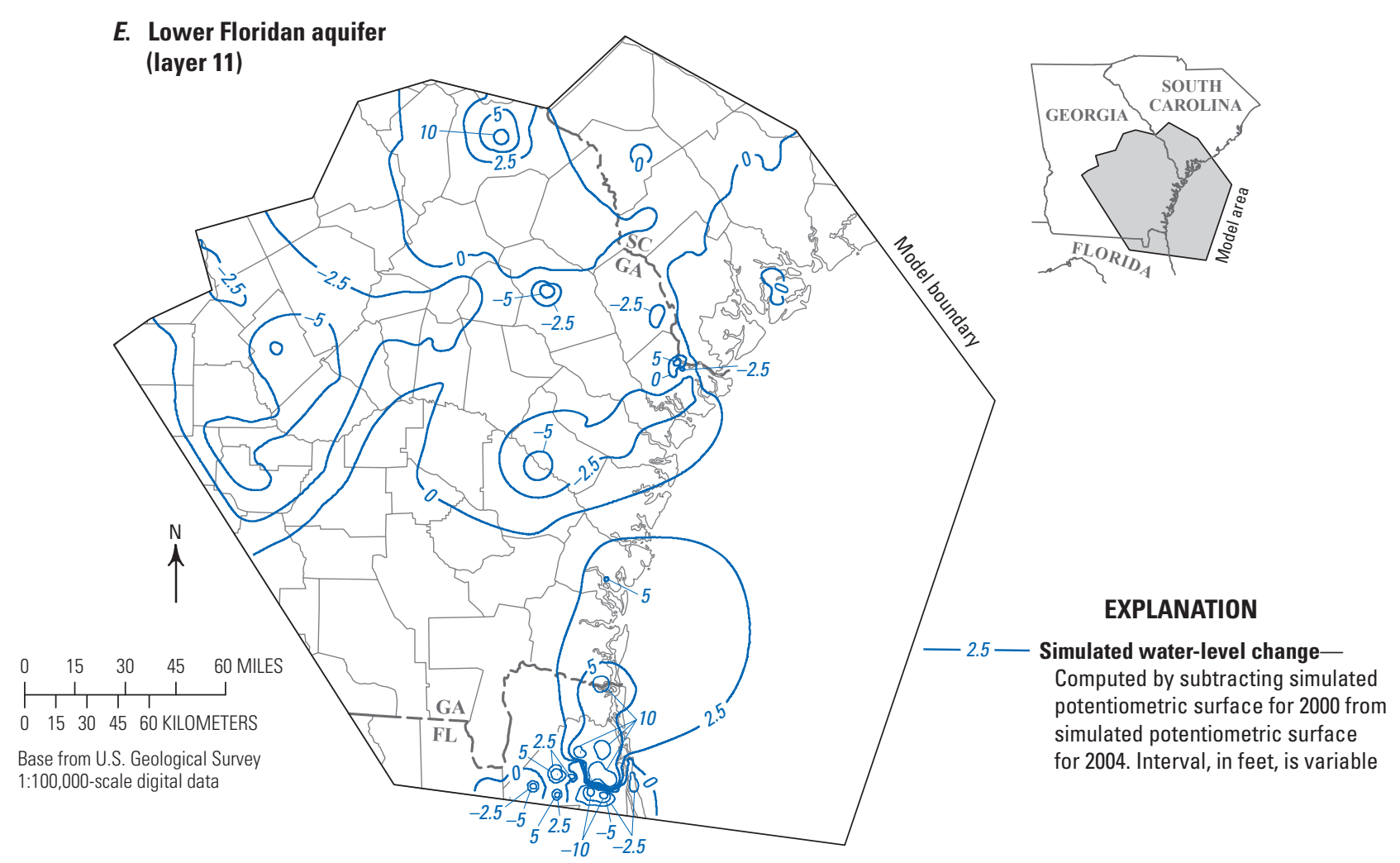

Figure 18. Simulated water-level change from 2000 to 2004 for $A$, model layer 3, upper Brunswick aquifer, $B$, model layer 5 , lower Brunswick aquifer, $C$, upper water-bearing zone of Upper Floridan aquifer, $D$, lower water-bearing zone of Upper Floridan aquifer, and $E$, Lower Floridan aquifer.-Continued

Simulated water-level changes from 2000 to 2004 in the UFA (layers 7 and 9) were influenced by decreases in pumpage caused by the shutdown of the Durango Paper Company mill near St. Marys and local decreases in pumping rates near the cities of Savannah in Chatham County, Ga., and Waynesboro in Burke County, Ga. (fig. 18C-D). Closure of the Durango Paper Company mill corresponded with a $35.5 \mathrm{Mgal} / \mathrm{d}$ decrease in pumping rates in the UFA that, when simulated, caused more than $20 \mathrm{ft}$ of groundwater-level rise near the pumping center and smaller water-level rises in the southern coastal area of Georgia ranging from 2.5 to more than $7.5 \mathrm{ft}$.

In Glynn County, simulated water-level increases in the UFA (layers 7 and 9) were caused by decreases in pumping rates represented in the steady-state models from 2000 to 2004. Simulated groundwater-level increases generally ranged between 2.5 and $5 \mathrm{ft}$, with the greatest simulated increase occurring near downtown Brunswick. Decreases in pumping rates in the UFA from $61 \mathrm{Mgal} / \mathrm{d}$ during 2000 to $53.8 \mathrm{Mgal} / \mathrm{d}$ during 2004, represented in the models, contributed to the rises in simulated water levels. Decreases in simulated pumping rates that correspond with pumpage decline near the city of Savannah caused localized simulated rises in water levels of up to $2.5 \mathrm{ft}$.

A similar decrease in pumping rates occurred in the UFA near Waynesboro in Burke County as in Savannah, discussed above; however, a corresponding simulated water-level rise of more than $10 \mathrm{ft}$ resulted from this simulated pumpage reduction (fig. $18 C-D$ ). Inspection of hydraulic properties associated with both locations indicated that the lower hydraulic conductivity near Waynesboro, relative to Savannah, would elicit a larger groundwater-level response to pumpage there than in Savannah.

Simulated pumpage reductions corresponding to the shutdown of the Durango Paper Company mill had a similar effect on simulated water levels in the LFA (layer 11; fig. 18E) as on the UFA (fig. $18 C-D$ ). Simulated water-level rises of more than $10 \mathrm{ft}$ occurred near the center of pumping, with the $2.5-\mathrm{ft}$ contour extending through the central part of Glynn County. The simulated water-level rises in the LFA near the cities of Savannah and Waynesboro indicate that simulated groundwater levels responded to simulated pumpage reductions in the UFA (layers 7 and 9), indicating a strong hydraulic connection between the UFA and LFA. 


\section{Simulated Potentiometric Profiles}

Simulated potentiometric profiles were constructed for 2000 and 2004 to evaluate hydraulic gradients in the UWBZ of the UFA (layer 7) near the chloride plume and the cone of depression caused by production wells in the area (figs. 19 and 20). The profiles for 2000 and 2004 were selected based on available water-level data and principle groundwater-flow directions within the chloride plume. The principle direction of groundwater flow in the downtown Brunswick area is from south to north, with flow paths toward the northwest near the major well field. Potentiometric gradients determine groundwater-flow direction and rate in addition to influencing the shape and extent of the chloride plume. Potential changes in pumping could alter potentiometric gradients, the direction of groundwater flow, and the shape of the chloride plume. Simulated potentiometric gradients for 2000 were based on four potentiometric profiles $(A-D$; fig. 19) constructed using water-level data from 13 observation wells having a collective mean residual of $-0.19 \mathrm{ft}$. Simulated potentiometric gradients from these four profiles ranged from 3.6 to 5.2 feet per mile ( $\mathrm{ft} / \mathrm{mi})$. Simulated potentiometric gradients for 2004 were based on five potentiometric profiles ( $A-E$; fig. 20) constructed using water-level data from 18 observation wells having a collective mean residual of $-0.18 \mathrm{ft}$. Simulated potentiometric gradients from these five profiles ranged from 4.3 to $11.1 \mathrm{ft} / \mathrm{mi}$.
Simulated potentiometric gradients for 2000 approximated observed gradients in the four potentiometric profiles $(A-D)$ constructed in close proximity to the chloride plume. In potentiometric profile $A$, simulated water levels were about $1 \mathrm{ft}$ higher than observed water levels, with the simulated potentiometric gradient of $4.3 \mathrm{ft} / \mathrm{mi}$, similar to the observed gradient of $4.5 \mathrm{ft} / \mathrm{mi}$ (fig. 19; table 7). In potentiometric profile $B$, the simulated potentiometric gradient of $5.2 \mathrm{ft} / \mathrm{mi}$ nearly matched the observed gradient of $5.6 \mathrm{ft} / \mathrm{mi}$. Well $33 \mathrm{H} 130$, used to construct potentiometric profile $B$, represents the observation well located closest to the cone of depression caused by pumping, with a simulated water level of $-4.10 \mathrm{ft}$ and an observed water level of $-4.59 \mathrm{ft}$. In potentiometric profile $C$, simulated water levels were slightly higher than observed water levels, but potentiometric gradients were similar with a simulated value of $4.4 \mathrm{ft} / \mathrm{mi}$ and observed value of $5.3 \mathrm{ft} / \mathrm{mi}$. Potentiometric profile $C$ covers an area where groundwater flow shifts to a northwesterly direction toward a major well field, as indicated by the potentiometric contours shown in figure 14 . Potentiometric profile $D$ consists of nine wells oriented parallel to a primary groundwater-flow direction from south to north toward industrial production wells. The water levels in potentiometric profile $D$ illustrate the difficulty in matching observed and simulated values because of the apparent water-level fluctuations evident in wells $34 \mathrm{H} 373$ and $34 \mathrm{H} 355$. However, the plotted simulated and observed water levels indicate a reasonable match with a simulated potentiometric gradient of $3.6 \mathrm{ft} / \mathrm{mi}$ compared to an observed gradient of $4.1 \mathrm{ft} / \mathrm{mi}$.

Table 7. Simulated and observed groundwater levels for 2000 , and residuals in wells used to construct profiles in the Brunswick area.

[NAVD 88, North American Vertical Datum of 1988; - , not available; residual equals simulated minus observed water level; hydraulic gradients calculated using simulated heads at the endpoints of profiles; see figure 19 for location of profiles]

\begin{tabular}{|c|c|c|c|c|c|}
\hline \multirow{2}{*}{$\begin{array}{l}\text { Well } \\
\text { identifier }\end{array}$} & \multirow{2}{*}{ Profile(s) } & \multicolumn{2}{|c|}{$\begin{array}{c}2000 \text { water level, in feet above } \\
\text { or below (-) NAVD } 88\end{array}$} & \multirow{2}{*}{$\begin{array}{l}\text { Residual, } \\
\text { in feet }\end{array}$} & \multirow{2}{*}{$\begin{array}{c}\text { Simulated } \\
\text { potentiometric } \\
\text { gradient, in } \\
\text { feet per mile }\end{array}$} \\
\hline & & Simulated & Observed & & \\
\hline $33 \mathrm{H} 120$ & $A$ & -1.69 & -2.99 & 1.30 & - \\
\hline $34 \mathrm{H} 392$ & A & 4.23 & 3.33 & 0.90 & $4.3(\mathrm{~A})$ \\
\hline $33 \mathrm{H} 130$ & $B$ & -4.10 & -4.59 & 0.49 & - \\
\hline $34 \mathrm{H} 424$ & $B, D$ & 1.13 & 1.04 & 0.09 & $5.2(\mathrm{~B})$ \\
\hline $33 \mathrm{H} 133$ & C & -1.51 & -0.89 & -0.62 & - \\
\hline $34 \mathrm{H} 355$ & $C, D$ & 2.46 & 3.88 & -1.42 & $4.4(\mathrm{C})$ \\
\hline $34 \mathrm{H} 373$ & $D$ & 1.93 & -1.07 & 3.00 & - \\
\hline $34 \mathrm{H} 125$ & $D$ & 4.10 & 4.45 & -0.35 & - \\
\hline $34 \mathrm{H} 117$ & $D$ & 4.87 & 4.54 & 0.33 & - \\
\hline $34 \mathrm{H} 112$ & $D$ & 5.86 & 6.62 & -0.76 & - \\
\hline $34 \mathrm{H} 393$ & $D$ & 7.27 & 8.53 & -1.26 & - \\
\hline $34 \mathrm{H} 371$ & $D$ & 7.97 & 10.80 & -2.83 & - \\
\hline $34 \mathrm{H} 097$ & $D$ & 10.40 & 11.80 & -1.40 & $3.6(\mathrm{D})$ \\
\hline
\end{tabular}



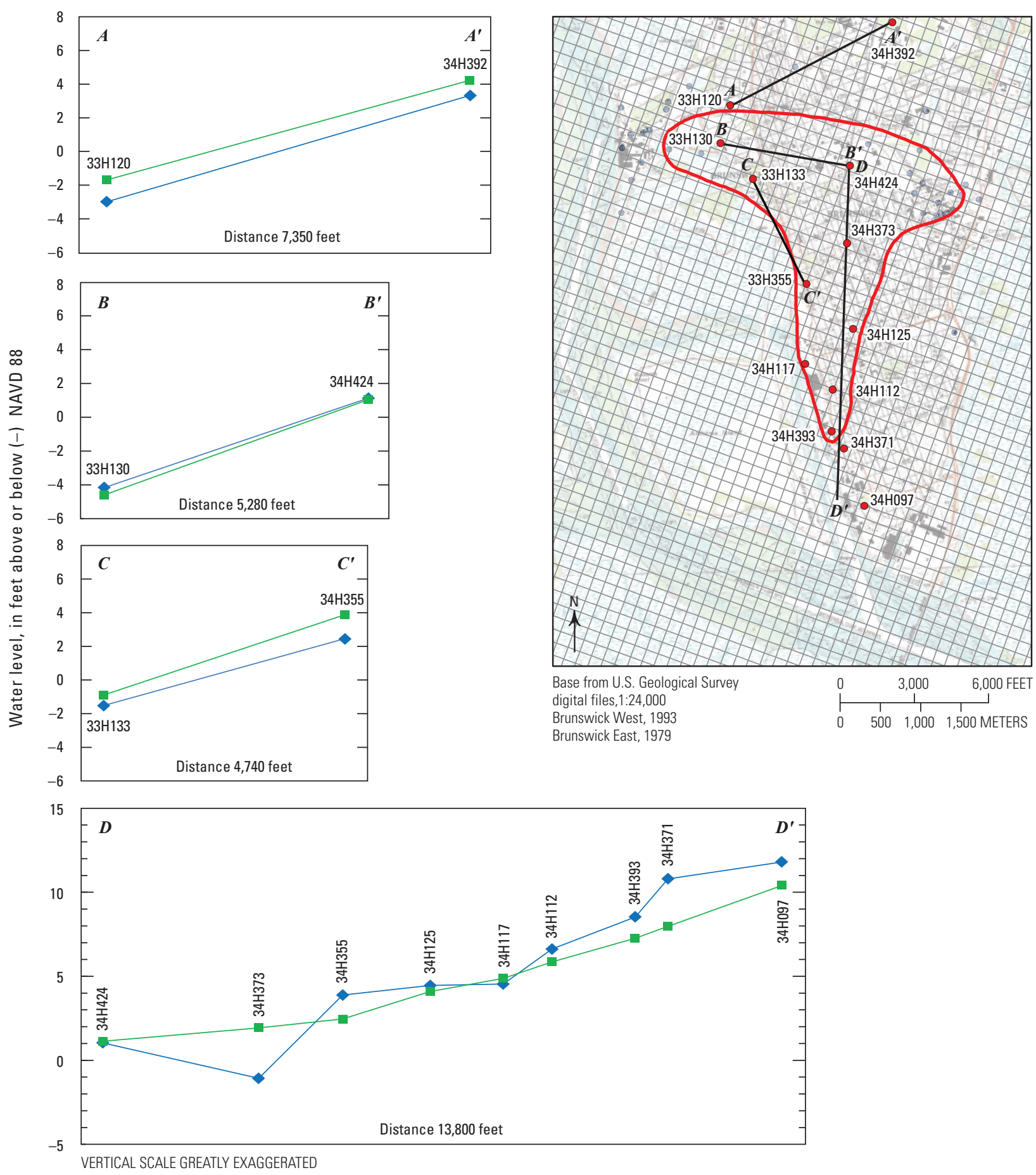

EXPLANATION

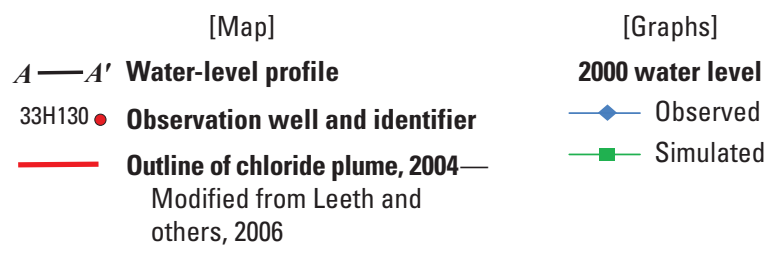

Figure 19. Simulated and observed potentiometric profiles near chloride plume during 2000. 

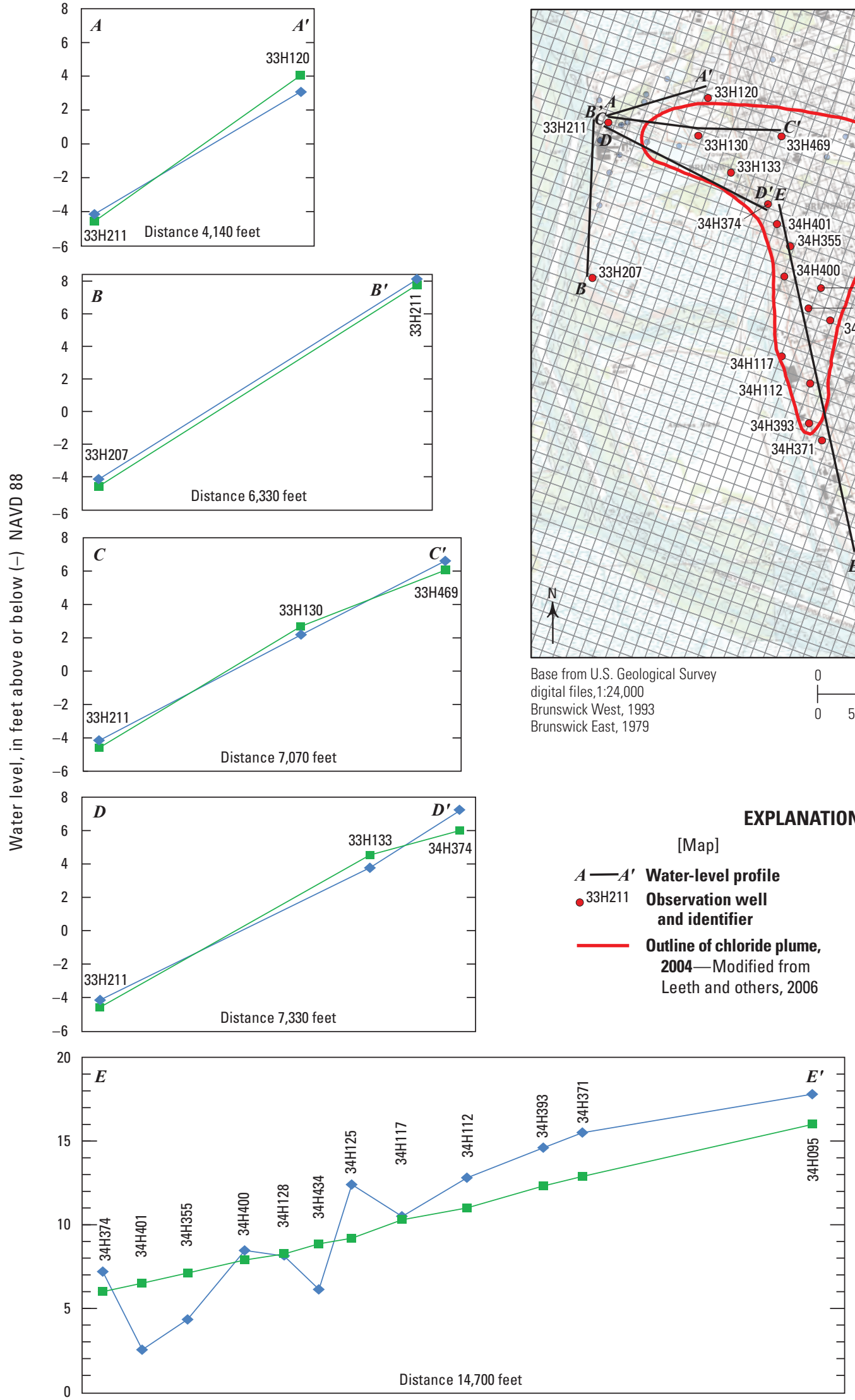

VERTICAL SCALE GREATLY EXAGGERATED

Figure 20. Simulated and observed potentiometric profiles near chloride plume during 2004.

33H211 Observation well Leeth and others, 2006

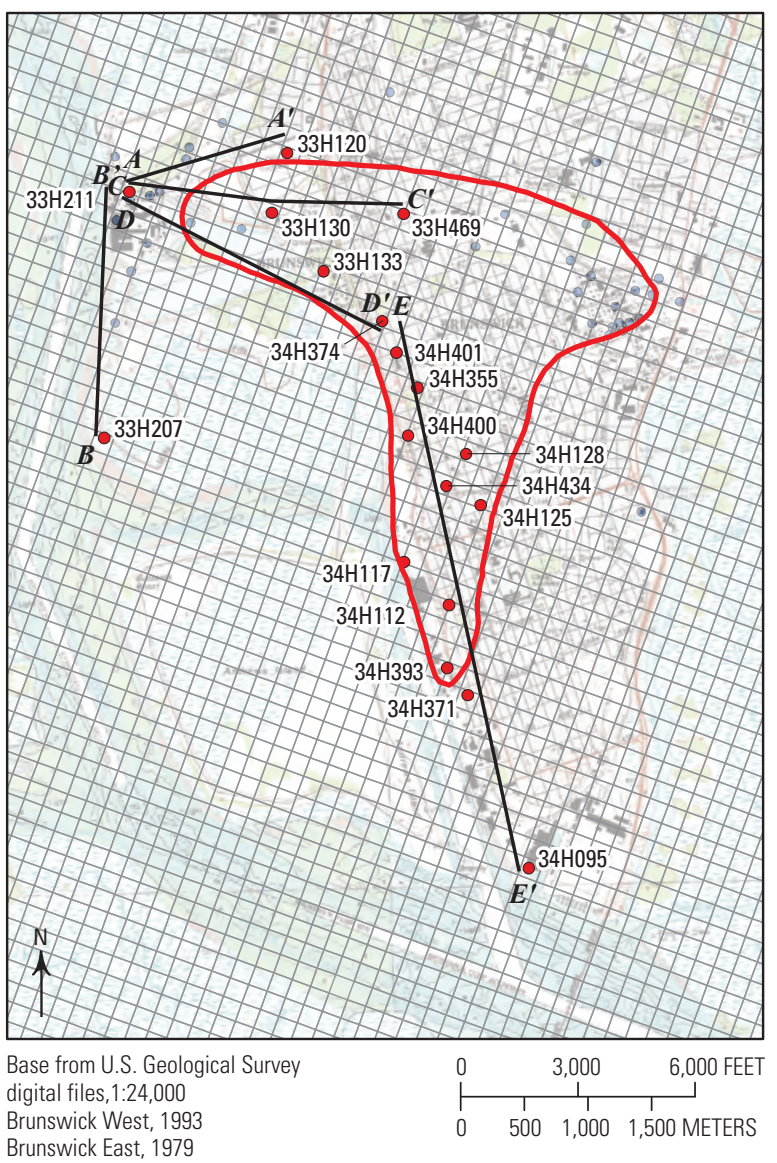

EXPLANATION

[Map]

$A-A^{\prime}$ Water-level profile and identifier

Outline of chloride plume, 2004-Modified from

2004 water level

$\multimap$ Observed

$\longrightarrow$ Simulated 
Simulated potentiometric gradients for 2004 approximated observed gradients in the five potentiometric profiles $(A-E)$ constructed in close proximity to the chloride plume. The potentiometric profiles for 2000 and 2004 differed slightly because the availability of observation water-level data differed between years (figs. 19 and 20; tables 7 and 8). In addition, water-level data available for well $33 \mathrm{H} 211$ allowed the 2004 potentiometric profiles to be constructed in close proximity to a major industrial well field. Consequently, simulated potentiometric gradients for 2004 were higher than the gradients for 2000. In potentiometric profile $A$, simulated water levels were lower than observed water levels in well $33 \mathrm{H} 211$ and higher than observed water levels in well $33 \mathrm{H} 120$, and have a simulated potentiometric gradient of $11.0 \mathrm{ft} / \mathrm{mi}$, higher than the observed gradient of $9.2 \mathrm{ft} / \mathrm{mi}$ (fig. 20; table 8). In potentiometric profile $B$, simulated water levels nearly matched observed values and have a simulated potentiometric gradient of $11.1 \mathrm{ft} / \mathrm{mi}$ and an observed gradient of $10.2 \mathrm{ft} / \mathrm{mi}$. In potentiometric profile $C$, simulated water levels were higher than observed water levels in well $33 \mathrm{H} 130$ and lower than observed values in wells $33 \mathrm{H} 211$ and $33 \mathrm{H} 469$ and have a simulated potentiometric gradient of $7.9 \mathrm{ft} / \mathrm{mi}$ compared to an observed gradient of $8.0 \mathrm{ft} / \mathrm{mi}$. In potentiometric profile $D$, residuals in wells $33 \mathrm{H} 211$ and $33 \mathrm{H} 133$ of -0.43 and $0.77 \mathrm{ft}$, respectively, indicate a reasonable match over this part of the potentiometric profile, with a residual of $-1.20 \mathrm{ft}$ at the endpoint in well $34 \mathrm{H} 374$. The water levels have a simulated potentiometric gradient of $7.6 \mathrm{ft} / \mathrm{mi}$, slightly lower than the observed gradient of $8.2 \mathrm{ft} / \mathrm{mi}$. Potentiometric profile $E$ consisted of 12 wells oriented parallel to a primary groundwater-flow direction from south to north toward industrial production wells. The observed water levels in potentiometric profile $E$ show fluctuations of nearly $5 \mathrm{ft}$ over the northern part of the profile without any apparent influence by localized pumping. Potentiometric profile $E$ shows observed water levels are higher than simulated values in wells $34 \mathrm{H} 374$, 34H400, 34H125, 34H112, 34H393, 34H371, and 34H095, but a comparison of graphed water levels over the entire profile indicates a reasonable match between simulated and observed values. The plotted simulated and observed water levels show a similar trend, with a simulated potentiometric gradient of $3.6 \mathrm{ft} / \mathrm{mi}$ and an observed gradient of $3.8 \mathrm{ft} / \mathrm{mi}$.

Table 8. Simulated and observed groundwater levels for 2004, and residuals in wells used to construct profiles in the Brunswick area.

[NAVD 88, North American Vertical Datum of 1988; —, not available; residual equals simulated minus observed water level; hydraulic gradients calculated using simulated heads at the endpoints of profiles; see figure 20 for location of profiles]

\begin{tabular}{|cccccc}
\hline \multirow{2}{*}{$\begin{array}{c}\text { Well } \\
\text { identifier }\end{array}$} & Profile(s) & \multicolumn{2}{c}{$\begin{array}{c}\text { 2004 water level, } \\
\text { in feet above NAVD 88 }\end{array}$} & $\begin{array}{c}\text { Sesidual, } \\
\text { in feet }\end{array}$ & $\begin{array}{c}\text { Simulated } \\
\text { potentiometric } \\
\text { gradient, in } \\
\text { feet per mile }\end{array}$ \\
\cline { 2 - 4 } & Simulated & Observed & & -0.43 & - \\
\hline $33 \mathrm{H} 211$ & $A, B, C, D$ & -4.59 & -4.16 & 0.97 & $11.0(\mathrm{~A})$ \\
\hline $33 \mathrm{H} 120$ & $A$ & 4.05 & 3.08 & -0.33 & $11.1(\mathrm{~B})$ \\
\hline $33 \mathrm{H} 207$ & $B$ & 7.76 & 8.09 & 0.51 & - \\
\hline $33 \mathrm{H} 130$ & $C$ & 2.69 & 2.18 & -0.56 & $7.9(\mathrm{C})$ \\
\hline $33 \mathrm{H} 469$ & $C$ & 6.05 & 6.61 & 0.77 & - \\
\hline $33 \mathrm{H} 133$ & $D$ & 4.54 & 3.77 & -1.20 & $7.4(\mathrm{D})$ \\
\hline $34 \mathrm{H} 374$ & $D, E$ & 6.00 & 7.20 & 3.98 & - \\
\hline $34 \mathrm{H} 401$ & $E$ & 6.51 & 2.53 & 2.78 & - \\
\hline $34 \mathrm{H} 400$ & $E$ & 7.12 & 4.34 & -0.56 & - \\
\hline $34 \mathrm{H} 355$ & $E$ & 7.90 & 8.46 & 0.13 & - \\
\hline $34 \mathrm{H} 128$ & $E$ & 8.26 & 8.13 & 2.73 & - \\
\hline $34 \mathrm{H} 434$ & $E$ & 8.86 & 6.13 & -3.20 & - \\
\hline $34 \mathrm{H} 125$ & $E$ & 9.20 & 12.40 & -0.20 & - \\
\hline $34 \mathrm{H} 117$ & $E$ & 10.30 & 10.50 & -1.86 & - \\
\hline $34 \mathrm{H} 112$ & $E$ & 11.04 & 12.90 & -2.28 & - \\
\hline $34 \mathrm{H} 393$ & $E$ & 12.32 & 14.60 & -2.61 & - \\
\hline $34 \mathrm{H} 371$ & $E$ & 12.89 & 15.50 & -1.91 & 4.3 (E) \\
\hline $34 \mathrm{H} 095$ & $E$ & 15.99 & 17.90 & & \\
\hline
\end{tabular}




\section{Simulated Water Budget}

The simulated 2000 and 2004 water budgets consist of the following major components of inflow and outflow to the groundwater-flow system: (1) inflow from the general-head boundaries, (2) inflow across lateral specified-head boundaries, (3) outflow to the general-head boundary, (4) discharge to wells, and (5) outflow across lateral specified-head boundaries. The 2000 and 2004 flows were characterized using the MODFLOW postprocessor ZONEBUDGET (Harbaugh, 1990). Flow calculations were summarized by model layer and by zone within each layer. Some zones were established to account for inflow and outflow across specified- and generalhead boundaries, flow between the layers, and flow along the coastline in a manner described by Payne and others (2005).

The entire simulated groundwater inflow to the model area for 2000 totaled $1,730 \mathrm{Mgal} / \mathrm{d}$, of which 28.3 percent (489 Mgal/d) constituted inflow from the general-head boundaries and 71.7 percent $(1,241 \mathrm{Mgal} / \mathrm{d})$ represented inflow from lateral specified-head boundaries in model layers 7, 8, 9, and 11 (table 9; fig. 21A). Simulated groundwater outflow totaled $1,730 \mathrm{Mgal} / \mathrm{d}$, of which 3.9 percent $(67.1 \mathrm{Mgal} / \mathrm{d})$ represented groundwater outflow to the general-head boundaries, and another 49.2 percent (852 Mgal/d) constituted outflow at lateral specified-head boundaries. Simulated discharge to wells totaled $811 \mathrm{Mgal} / \mathrm{d}$, or 46.9 percent of outflow, and was divided among the Brunswick aquifer system (layers 3 and 5; $0.24 \mathrm{Mgal} / \mathrm{d}$ ), the UWBZ and LWBZ of the UFA (layers 7 and 9; $679 \mathrm{Mgal} / \mathrm{d}$ ), and the LFA (layer $11 ; 131 \mathrm{Mgal} / \mathrm{d}$ ). Net inflow to the model area along lateral specified-head boundaries totaled about $370 \mathrm{Mgal} / \mathrm{d}$ for the UFA (layers 7-9) and $18.6 \mathrm{Mgal} / \mathrm{d}$ for the LFA (table 9; fig. 21 $A$ ).

Simulated inflow to the model for 2004 totaled 1,540 Mgal/d, and was divided between general-head boundaries (470 Mgal/d, or 30.5 percent), and lateral specifiedhead boundaries in layers 7, 8, 9, and $11(1,070 \mathrm{Mgal} / \mathrm{d}$, or 69.5 percent) (table 9; fig. $21 B$ ). Outflow from the model totaled $1,540 \mathrm{Mgal} / \mathrm{d}$, of which 4.8 percent $(74.2 \mathrm{Mgal} / \mathrm{d})$ represented groundwater outflow to the general-head boundaries, and another 47.6 percent $(733 \mathrm{Mgal} / \mathrm{d})$ was attributed to outflow at lateral specified-head boundaries. The remaining 47.6 percent $(733 \mathrm{Mgal} / \mathrm{d}$ ) represented simulated discharge to wells from the Brunswick aquifer system (layers 3 and $5 ; 1.75 \mathrm{Mgal} / \mathrm{d}$ ), the UWBZ and LWBZ of the UFA (layers 7 and 9; $619 \mathrm{Mgal} / \mathrm{d}$ ), and the LFA (layer 11; $112 \mathrm{Mgal} / \mathrm{d})$. Net inflow along lateral specified-head boundaries totaled about $315 \mathrm{Mgal} / \mathrm{d}$ into the UFA (layers 7-9), and 22.1 Mgal/d into the LFA (table 9; fig. 21B).

A comparison of the major components for 2000 and 2004 indicates higher inflow values through the general-head boundary in layer 1 for the 2000 simulation. The $78-\mathrm{Mgal} / \mathrm{d}$ greater pumping rate during 2000, relative to 2004 induced an additional $19.3 \mathrm{Mgal} / \mathrm{d}$ of inflow through the general-head boundaries in layers 1,2, and 7, and an additional $171 \mathrm{Mgal} / \mathrm{d}$ of inflow to the model through the specified-head boundary in layers 7, 8, 9, and 11 when compared to the 2004 budget. The comparison between the simulated water budgets for 2000 and 2004 indicates increased inflows in the UFA along the southern specified-head boundary. According to Payne and others (2005), these inflows are reasonable because the UFA extends far beyond this specified-head boundary throughout Florida (Miller, 1986) and potentially could contribute groundwater into the modeled area. The resulting inflows along this boundary decreased from 1,241 Mgal/d during 2000 to $1,070 \mathrm{Mgal} / \mathrm{d}$ for the 2004 simulation, which subdivided the UFA (layer 5) into the UWBZ and LWBZ (layers 7 and 9) and the intervening confining unit (layer 8).

An analysis similar to that described for general headboundaries in the Brunswick/Glynn County area indicated that specified-head boundaries adjacent to Glynn County are located sufficiently far from the pumping centers to yield a significant contribution to the water budget (fig. $21 C-D$; table 10). In the Brunswick/Glynn County area, simulated pumping totaled $60.9 \mathrm{Mgal} / \mathrm{d}$ during 2000 and $55.2 \mathrm{Mgal} / \mathrm{d}$ during 2004. Outflows to the general-head boundary in model layer 1 of 4.0 and $5.8 \mathrm{Mgal} / \mathrm{d}$ (for 2000 and 2004 simulated conditions, respectively) exceeded inflows of 0.35 and $0.21 \mathrm{Mgal} / \mathrm{d}$, respectively, along the same boundary. 
Table 9. Flow-budget components for 2000 and 2004 for entire model area.

[Results from MODFLOW model; all values in million gallons per day; - , not applicable]

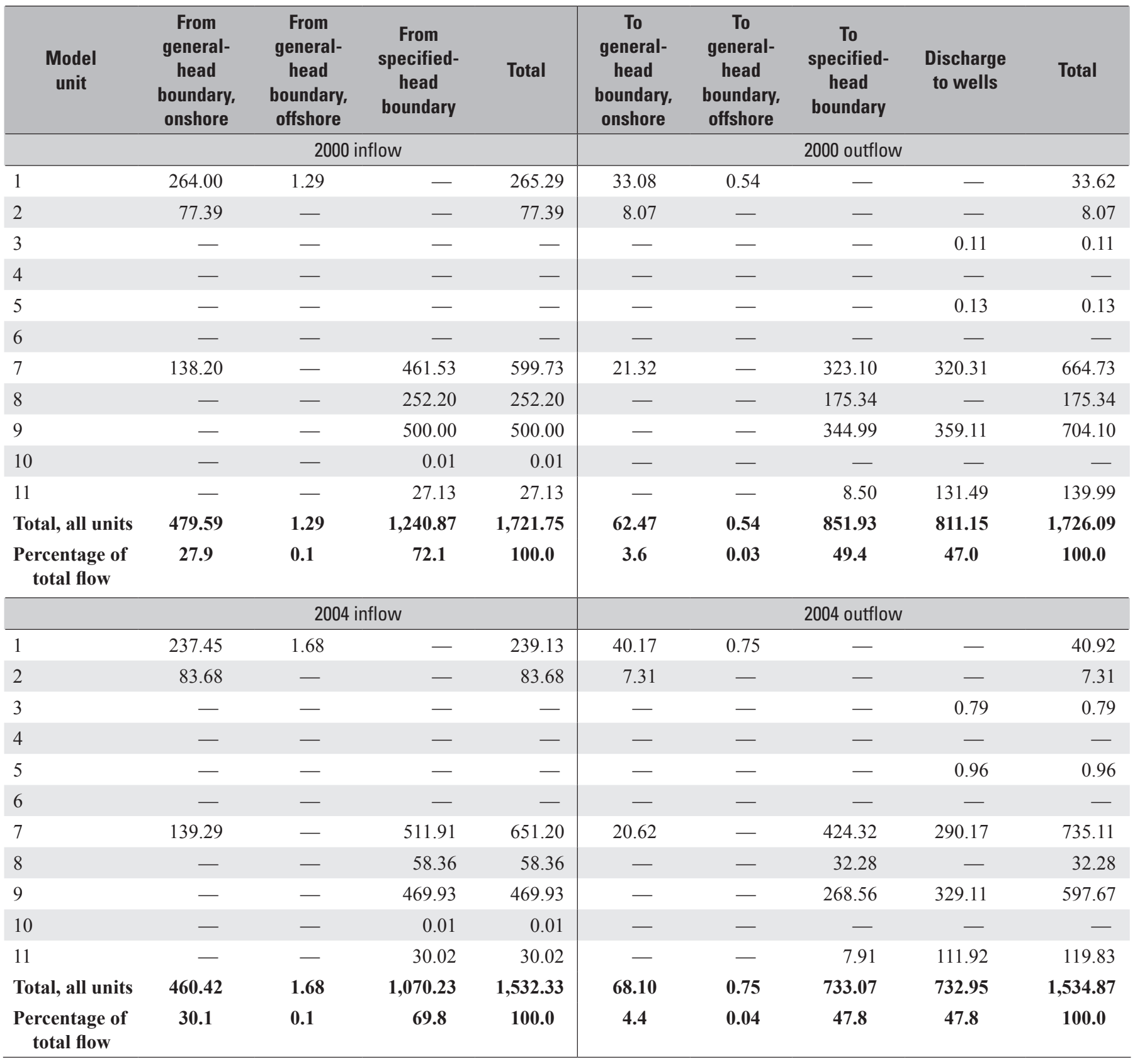


Table 10. Flow-budget components for 2000 and 2004 in the Brunswick/Glynn County area.

[Results from MODFLOW model; all values in million gallons per day; — , not applicable]

\begin{tabular}{|c|c|c|c|c|c|c|c|}
\hline $\begin{array}{l}\text { Model } \\
\text { unit }\end{array}$ & $\begin{array}{c}\text { From } \\
\text { general-head } \\
\text { boundary, } \\
\text { onshore }\end{array}$ & $\begin{array}{c}\text { Across } \\
\text { county } \\
\text { boundaries }\end{array}$ & Total & $\begin{array}{c}\text { To } \\
\text { general-head } \\
\text { boundary, } \\
\text { onshore }\end{array}$ & $\begin{array}{c}\text { Across } \\
\text { county } \\
\text { boundaries }\end{array}$ & $\begin{array}{c}\text { Discharge } \\
\text { to wells }\end{array}$ & Total \\
\hline & & 2000 inflow & & \multicolumn{4}{|c|}{2000 outflow } \\
\hline 1 & 0.35 & 4.89 & 5.24 & 3.96 & 1.59 & - & 5.55 \\
\hline 2 & - & - & - & - & - & - & - \\
\hline 3 & - & 0.14 & 0.14 & - & 0.07 & 0.05 & 0.12 \\
\hline 4 & - & - & - & - & - & - & - \\
\hline 5 & - & 0.35 & 0.35 & - & 0.18 & 0.06 & 0.24 \\
\hline 6 & - & - & - & - & - & - & - \\
\hline 7 & - & 42.51 & 42.51 & - & 15.34 & 24.32 & 39.66 \\
\hline 8 & - & 0.26 & 0.26 & - & 2.25 & - & 2.25 \\
\hline 9 & - & 50.10 & 50.10 & - & 16.57 & 36.46 & 53.03 \\
\hline 10 & - & - & - & - & - & - & - \\
\hline 11 & - & 4.21 & 4.21 & - & 1.96 & 0.00 & 1.96 \\
\hline Total, all units & 0.35 & 102.46 & 102.81 & 3.96 & 37.96 & 60.89 & 102.81 \\
\hline \multirow{2}{*}{$\begin{array}{l}\text { Percentage of } \\
\text { total flow }\end{array}$} & 0.3 & 99.7 & 100.0 & 3.9 & 36.9 & 59.2 & 100.0 \\
\hline & & 2004 inflow & & \multicolumn{4}{|c|}{2004 outflow } \\
\hline 1 & 0.21 & 8.12 & 8.33 & 5.80 & 2.62 & - & 8.42 \\
\hline 2 & - & - & - & - & - & - & - \\
\hline 3 & - & 0.31 & 0.31 & - & 0.05 & 0.64 & 0.69 \\
\hline 4 & - & - & - & - & - & - & - \\
\hline 5 & - & 0.78 & 0.78 & - & 0.12 & 0.81 & 0.93 \\
\hline 6 & - & - & - & - & - & - & - \\
\hline 7 & - & 38.31 & 38.31 & - & 14.56 & 19.64 & 34.20 \\
\hline 8 & - & 0.02 & 0.02 & - & 0.47 & - & 0.47 \\
\hline 9 & - & 45.19 & 45.19 & - & 15.64 & 34.14 & 49.78 \\
\hline 10 & - & - & - & - & - & - & - \\
\hline 11 & - & 3.84 & 3.84 & - & 2.29 & 0.00 & 2.29 \\
\hline Total, all units & 0.21 & 96.57 & 96.78 & 5.80 & 35.75 & 55.23 & 96.78 \\
\hline $\begin{array}{c}\text { Percentage of } \\
\text { total flow }\end{array}$ & 0.2 & 99.8 & 100.0 & 6.0 & 36.9 & 57.1 & 100.0 \\
\hline
\end{tabular}



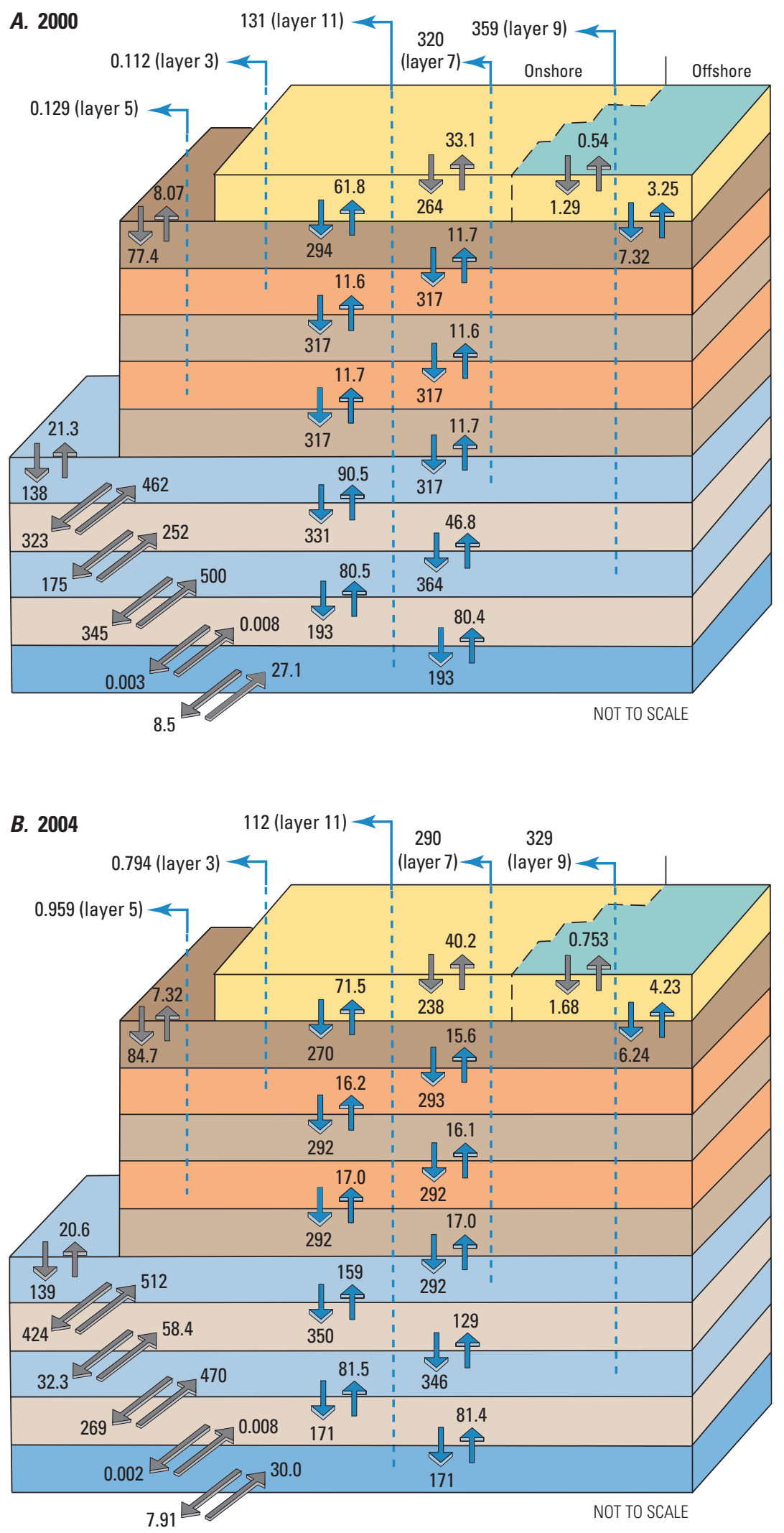

Surficial aquifer system (layer 1)

Brunswick aquifer system confining unit (layer 2)

Upper Brunswick aquifer (layer 3)

Lower Brunswick confining unit (layer 4)

Lower Brunswick aquifer (layer 5)

Upper Floridan confining unit (layer 6)

Upper water-bearing zone Upper Floridan aquifer (layer 7) Lower water-bearing zone Upper Floridan confining unit (layer 8)

Lower water-bearing zone Upper Floridan aquifer (layer 9)

Lower Floridan confining unit (layer 10)

Lower Floridan aquifer (layer 11)

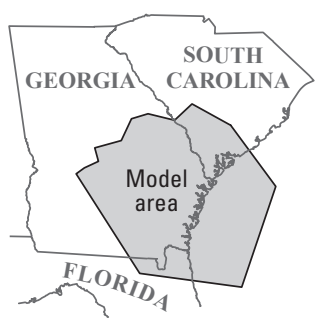

\section{EXPLANATION}

Groundwater flow, in million gallons per day, and budget component

$$
\overbrace{1.8}^{0.753} \text { General-head boundary }
$$

Interunit leakage

6.24

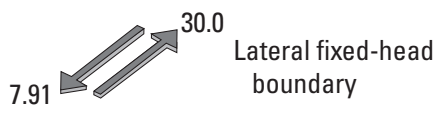

$329 \leftarrow$ Pumpage

Figure 21. Schematic diagram showing simulated water budget for regional model during $A, 2000$ and $B, 2004$, and water budgets in Glynn County during C, 2000 and D, 2004. 


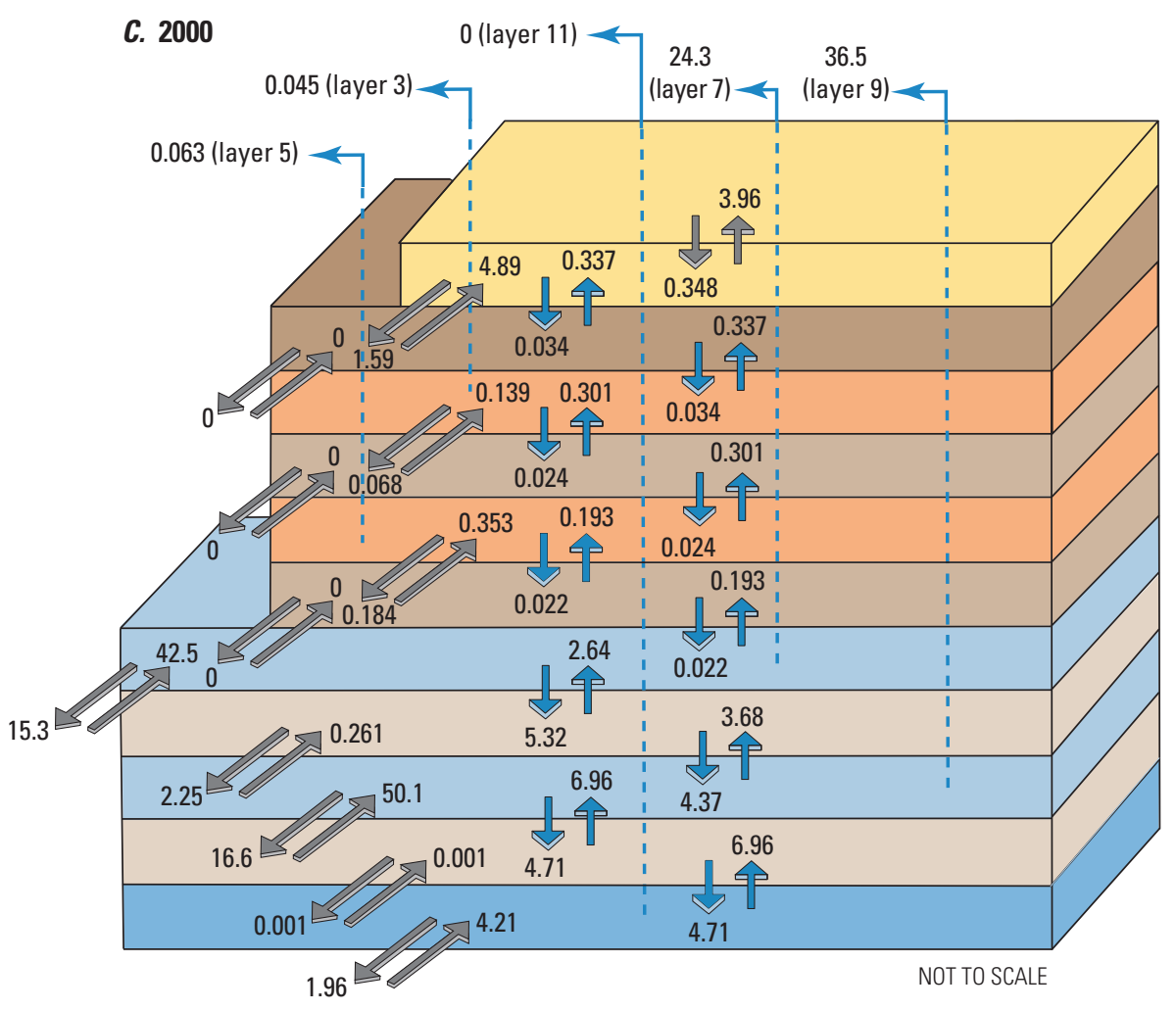

Surficial aquifer system (layer 1)

Brunswick aquifer system confining unit (layer 2)

Upper Brunswick aquifer (layer 3)

Lower Brunswick confining unit (layer 4)

Lower Brunswick aquifer (layer 5)

Upper Floridan confining unit (layer 6)

Upper water-bearing zone Upper Floridan aquifer (layer 7)

Lower water-bearing zone Upper Floridan confining unit (layer 8)

Lower water-bearing zone Upper Floridan aquifer (layer 9)

Lower Floridan confining unit (layer 10)

Lower Floridan aquifer (layer 11)
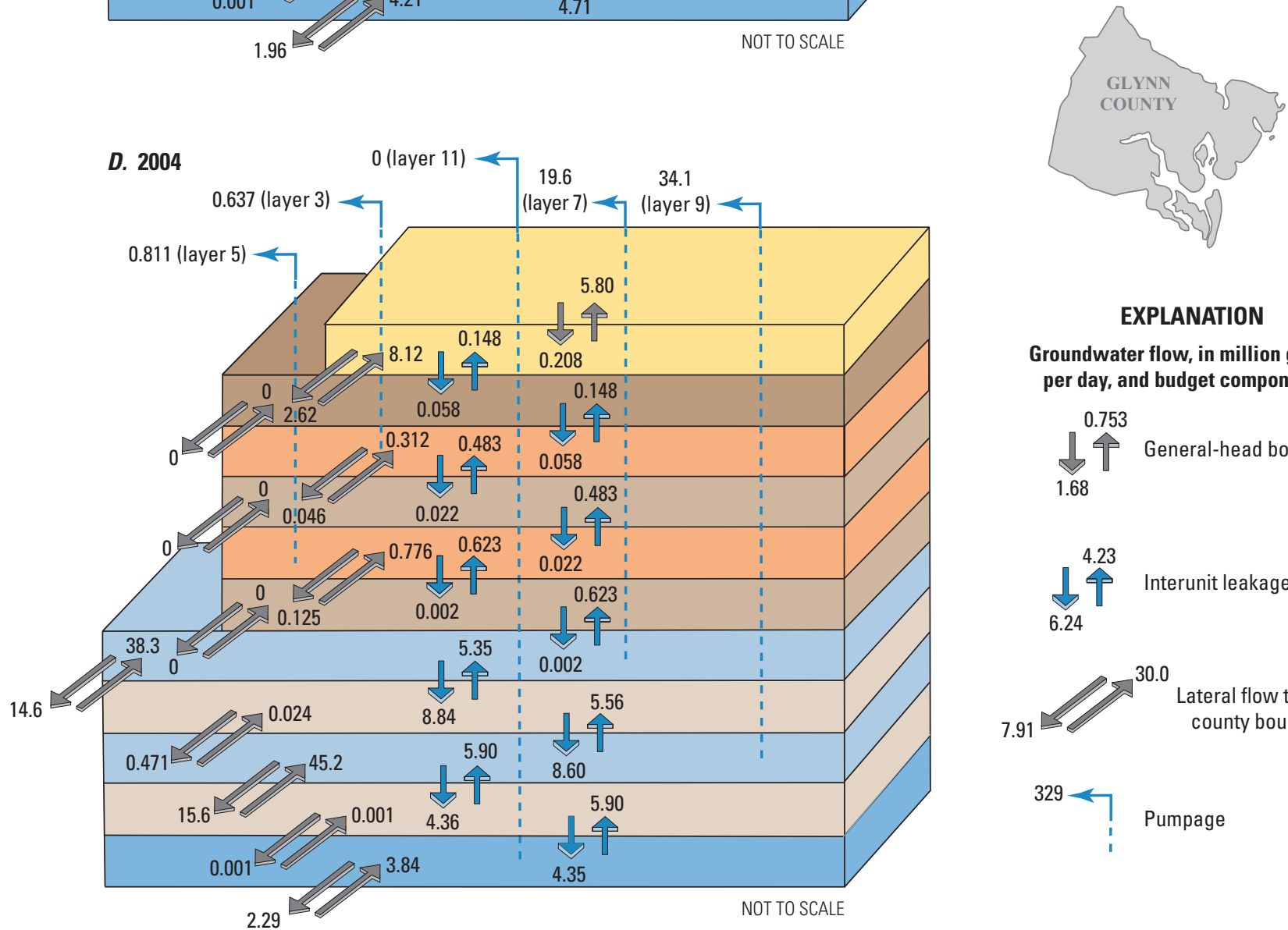

\section{EXPLANATION}

Groundwater flow, in million gallons per day, and budget component
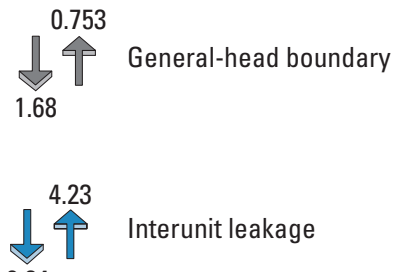

6.24

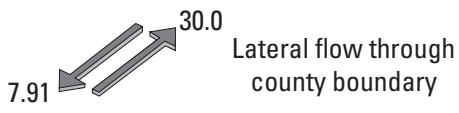

$329 \leftarrow$ Pumpage

Figure 21. Schematic diagram showing simulated water budget for regional model during $A, 2000$ and $B, 2004$, and water budgets in Glynn County during $C, 2000$ and D, 2004.-Continued 


\section{Model Sensitivity}

The sensitivity of the calibrated revised steady-state model was evaluated to determine the relative importance of introduced hydraulic conductivity parameters in the Brunswick/Glynn County area. The original model used the perturbation method to examine model sensitivity to pumping and to the specified-head boundary condition along the southern boundary (Payne and others, 2005). The composite-scaled sensitivity analysis for the original model indicated high sensitivity to pumping rates. Therefore, 2000 pumping rates were increased by 10 percent and the resulting changes in simulated heads and flow rates were documented. The specified-head boundary along the southern edge of the original model was increased by $10 \mathrm{ft}$ and the resulting rise in simulated water levels mapped. Published maps indicate increases in simulated water levels in the Brunswick/Glynn County area of about $8 \mathrm{ft}$. The results of the 10-percent increase in 2000 pumping rates indicate simulated water-level decreases ranging between 2 and $6 \mathrm{ft}$ in the Brunswick/Glynn County area. These perturbations were not repeated for the revised model because of similarities in model construction, and the reader is referred to Payne and others (2005) for full details of this analysis.

The current study focused on the composite-scaled sensitivity analysis of the revised model in the Brunswick/ Glynn County area. Composite-scaled sensitivities for comparable parameters are calculated using the sensitivity equation described in MODFLOW-2000 (Hill and others, 2000), and as described in Hill (1998), composite-scaled sensitivity is a dimensionless measure of the change in calculated head with respect to the value of a parameter. The resulting sensitivities are independent of the actual values of the observations. A large composite-scaled sensitivity indicates a relatively high sensitivity of the model to changes in a given parameter, whereas a small composite-scaled sensitivity indicates low model sensitivity to such changes. Composite-scaled sensitivities were used to evaluate the relative sensitivities of the model to pumping rate, vertical and horizontal hydraulic conductivity, and the conductance of the general-head boundary.

Composite-scaled sensitivities for parameters in both the 2000 and 2004 simulations indicate that the model is approximately 5.2 and 4.5 times more sensitive to pumping rate (wells) for both years than to the parameter with the next highest composite-scaled sensitivity (fig. 22). Although the model is more sensitive to the horizontal hydraulic conductivity of the UFA (layers 7, 8, and 9) than to several vertical hydraulic conductivities (CU5Kv, CU1Kv, CU3Kv, and CU2Kv), composite-scale sensitivities (which range from 0.17 to 2.2) are about an order of magnitude or two less than the parameter with the highest composite-scaled sensitivity, wells. The other parameters representing vertical hydraulic conductivities in the aquifers (layers 3, 5, 7, 9, and 11) and horizontal hydraulic conductivities of the confining units (layers $2,4,6,8$, and 10) yielded negligible composite-scale sensitivities and are not included in figure 22 . The horizontal hydraulic conductivity parameters having the highest composite-scaled sensitivity represented zones south of the Gulf Trough (UF4Kh, UF6Kh, UF5Kh, UF8Kh, UF12Kh, and UF7Kh).

Parameters created for the revised model to subdivide the UWBZ and LWBZ of the UFA in the Brunswick/Glynn County area yielded composite-scaled sensitivities near or below one (UF16Kh, UF15Kh, UF18Kh, UF14Kh, UF17Kh, and UF13Kh, fig. 22). The calculated composite-scaled sensitivities varied between the 2000 and 2004 simulations, with the 2000 simulation having greater values (ghb, UF11Kh, SURFKh, CU1Kv, UF2Kh, and UF1Kh).

\section{Model Limitations}

The original model was constructed to simulate groundwater flow in the Floridan aquifer system, which encompasses parts of Georgia, South Carolina, Alabama, and all of Florida. The spatial representation of hydrogeologic units and discretization of these subsurface units into model layers generalize and simplify the subsurface and areal details of aquifer geometry, which imposes limitations on model accuracy. For example, the location of specified-head boundaries in the Floridan aquifer system permits groundwater to enter the model area near the Florida-Georgia State Line but does not allow groundwater levels to change along this boundary in response to pumping in the Brunswick/Glynn County area, located a few miles north of the state line.

The results obtained from steady-state simulations using the revised model developed for the Brunswick/Glynn County area are subject to uncertainty and errors inherent to the numerical approximation of the groundwater flow equation by finite-difference methods (Remson and others, 1971), and to the same limitations of model application inherent with discretization and sparse subsurface data as those documented in the original model (Payne and others, 2005).

All groundwater models represent a simplification of a complex natural physical system and undoubtedly limit its representation with incomplete information derived from sparse point data to define continuous subsurface phenomena at discrete locations. The use of a coarse finite-difference grid in the upland regions of the study area limits model representation of the geometry of the physical extent of aquifers and confining units. Because these upland regions are located far from the areas of interest containing pumpage, the effect of this limitation on the computed solution of hydraulic head is minimal. The constraint that finite-difference grids adhere to an orthogonal system of discretization limits the ability of the computed solution of hydraulic head to represent curvature or hydraulic gradients in potentiometric surfaces. 
Model Limitations

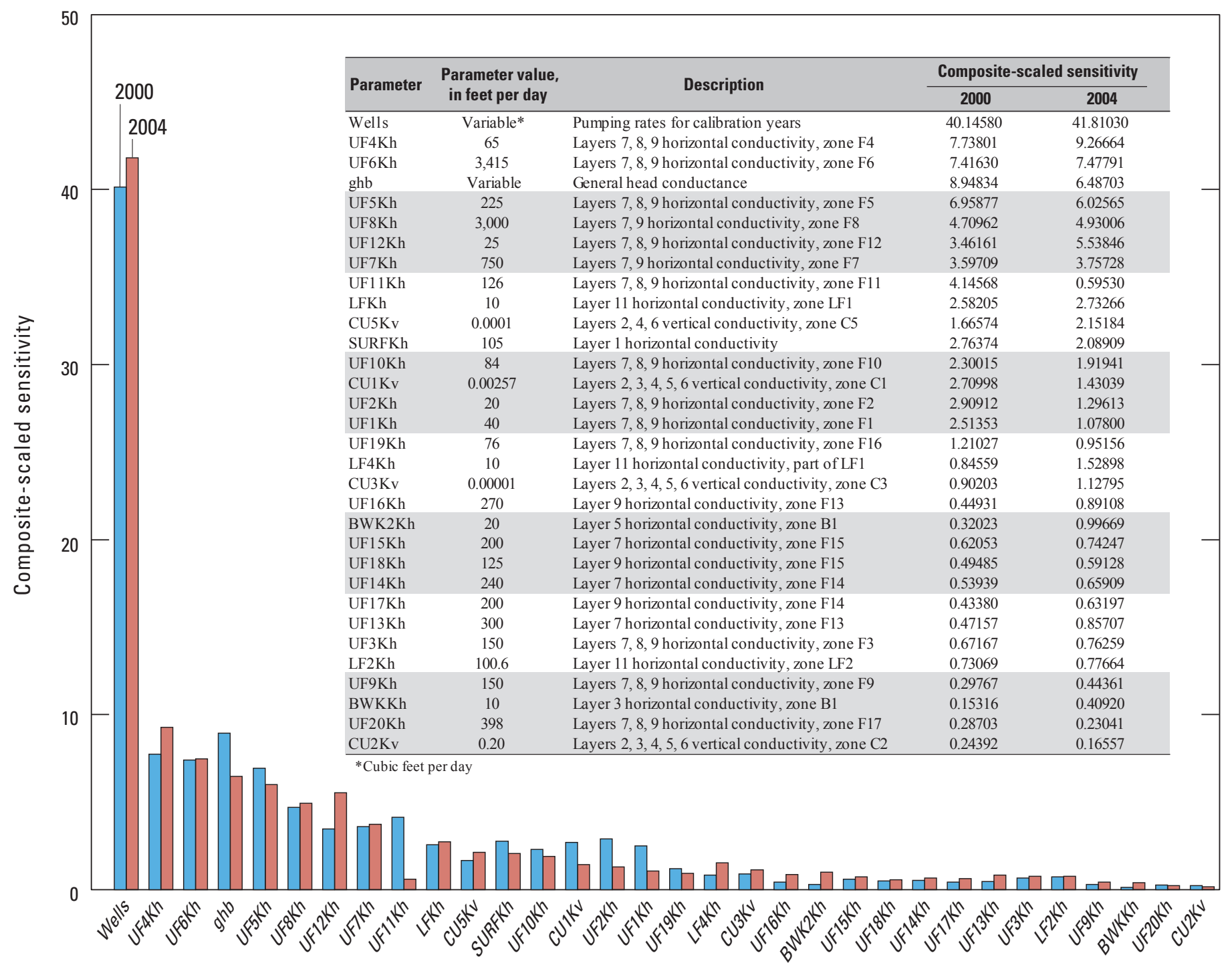

Parameter

Figure 22. Composite-scaled sensitivity of selected model parameters. 
Groundwater Flow in the Brunswick/Glynn County Area, Georgia, 2000-04

The original model discretized the study area into large grid cells on the fringes of the areas of interest, and used small grid cells to focus on providing a detailed simulation of hydraulic head in the areas of interest, namely, in and near the cities of Savannah and Brunswick. Grid cells as small as 4,000 by $5,000 \mathrm{ft}$ were used in areas where detailed simulated groundwater levels were required to be computed with the original model, such discretization provided a computed solution of hydraulic head in the center of the grid cell. This computed value applied to the entire grid cell area, about 0.8 to $1 \mathrm{mi}^{2}$, which was inadequate for representing local pumping effects such as drawdown cones and changes in hydraulic gradient. Trial-and-error testing of alternate grid spacing indicated that square grid cells measuring $500 \mathrm{ft}$ per side would provide adequate representation of pumping effects on the potentiometric surfaces in and near pumping centers in the UFA at Savannah and in the Brunswick/Glynn County area. This fine grid spacing was expanded near the City of Savannah, however, to improve computational efficiency of the model, which sacrificed accuracy in the computed solution in Chatham County.

Additional data have become available for the Brunswick aquifer system since the original model was constructed that allowed the upper and lower Brunswick aquifers to be included in the revised model. Most of the new aquifer-test data are from the vicinity of Glynn County, however, and the lateral extent of the system as well as the aquifer properties remain uncertain outside this area. The units are assumed to be continuous but could be isolated in areas because of locally reduced permeabilities and aquifer thinning.

The UFA was represented by layer 5 in the original model and was subdivided in the revised model into the UWBZ, intervening confining unit, and the LWBZ, represented as layers 7 through 9, respectively. The extent of this subdivision was limited to Glynn and Camden Counties, however. Outside these counties, the intervening confining unit was assigned the same hydraulic conductivity as the model layers above and below because the extent of distinct water-bearing zones in the UFA remained uncertain. Water-level data were available from only five wells for the LWBZ of the UFA (layer 9), which provided few points to calibrate simulated water levels against and proved difficult to match in both 2000 and 2004. The pumping distribution was assigned for model layers 7 and 9 in the Brunswick/Glynn County area based on aquifer thickness, but the flowmeter data needed to determine the relative contributions from each of the units were either uncertain or conflicting.

The revised groundwater-flow model was calibrated to hydrologic conditions during September 2000 and June 2004 using steady-state simulations that did not account for temporal variations. Transient simulations would consider small-scale changes and seasonal responses to recharge and pumping but were beyond the scope of this study. Groundwater hydrographs (fig. 6) indicate time-varying water levels, which give rise to time-varying hydraulic gradients and configurations of the potentiometric surface. Pumping rates are not sufficiently constant over time, nor are boundary conditions, to warrant the use of a steady-state model. Storage effects in the aquifer and confining units delay the drawdown response to pumping, and such aquifer and confining unit responses may not be fully realized before the pumping stress changes, which creates another condition to which the aquifer and confining unit would respond through time. The steadystate models of 2000 and 2004 conditions do not represent such time-varying elements of the groundwater-flow system, which severely limits the model's usefulness in comparing computed steady-state solutions of hydraulic head to water levels measured in a non-steady-state aquifer condition.

Boundary conditions play an important role in the calibration of the revised model, but impose a severe limitation on the model's ability to represent the actual aquifer response to pumping. The flow budgets for the 2000 and 2004 steadystate simulations indicate the specified-head boundaries in model layers 7 through 11 account for nearly 70 percent of the inflows (1,240 Mgal/d, year 2000; 1,070 Mgal/d, year 2004) and about 50 percent of the outflows (852 Mgal/d, year 2000; $733 \mathrm{Mgal} / \mathrm{d}$, year 2004). Almost all of the water pumped is derived from either induced inflow or reduced outflow across specified-head boundaries. The general-head boundary in model layers 1, 2, and 5 supplies about 30 percent of the inflows (480 Mgal/d, 2000; $460 \mathrm{Mgal} / \mathrm{d}, 2004$ ) as simulated recharge, with the amount controlled by a conductance term, but the specified-head boundary can become an unlimited supply of simulated recharge to the groundwater system and can be increased by increasing pumping. The observed head data for 2004 were limited but were used to assign specifiedhead values along the extent of this boundary. This boundary condition will supply limitless quantities of water in response to pumping and cannot be constrained, such as assigning recharge to specific areas of the model. The inherent assumption is that the specified-head boundary is sufficiently far from the area of primary interest such that cones of depression do not intersect the specified-head boundary during the simulation. The same assumption applies to general-head boundaries.

Pumping uncertainty results from errors in data-collection procedures, errors in reporting, overestimating or underestimating county-wide water use, and uncertainties in the assignment of pumping to model layers. Large discrepancies can exist between site-specific and non-site-specific data, which would assign higher pumping rates to non-site-specific wells and possibly alter input hydraulic-property data to a given area of the model. 


\section{Summary}

Modifications to the original regional MODFLOW groundwater-flow model of coastal Georgia and adjacent parts of Florida and South Carolina allowed a revised model to be utilized in the evaluation of hydraulic gradients in the Upper Floridan aquifer near downtown Brunswick for 2000 and 2004. Reducing the finite-difference grid spacing in the downtown Brunswick area from the original 4,000 $\times 5,000$ feet (ft) to $500 \times 500 \mathrm{ft}$ permitted the simulation of hydraulic gradients that closely matched observed hydraulic gradients near a cone of depression resulting from large-scale pumping near active production wells. Modifications to model layering for the revised model consisted of (1) subdividing the Brunswick aquifer system into two aquifer layers (layers 3 and 5) separated by an intervening confining unit (layer 4) and (2) subdividing the Upper Floridan aquifer into upper and lower water-bearing zones with distinct layers (layers 7 and 9) separated by a confining unit (layer 8 ). Additional hydraulic property zones were established for the Brunswick aquifer system (layers 3-5) and Floridan aquifer system (layers 7-9) based on additional aquifer-test data and hydrogeologic structure. Additional adjustments to hydraulic-property zones improved the match between simulated and observed water levels for 2000 and 2004.

Calibration of the revised model using 2000 pumping rates from the original model indicated a "good" match ( $\pm 10 \mathrm{ft}$ ), with mean residuals (simulated minus observed water level) in each of the active model layers ranging from -4.57 to $5.66 \mathrm{ft}$, median residuals ranging from -8.62 to $4.67 \mathrm{ft}$, and root mean square error (RMSE) ranging from 10.9 to $11.4 \mathrm{ft}$. In the Brunswick/Glynn County area, calibration in the upper water-bearing zone of the Upper Floridan aquifer (layer 7) for 2000 improved with a mean residual of $-1.30 \mathrm{ft}$, median residual of $-0.35 \mathrm{ft}$, and a RMSE of $4.32 \mathrm{ft}$.

Calibrations of the revised model using of 2004 pumping and boundary conditions indicate a "good' match $( \pm 10 \mathrm{ft})$, with mean residuals in each active model layer ranging from -5.60 to $1.20 \mathrm{ft}$, median residuals ranging from -6.31 to $-2.05 \mathrm{ft}$, and a RMSE ranging from 6.95 to $14.5 \mathrm{ft}$. The match between simulated and observed water levels in the upper water-bearing zone of the Upper Floridan aquifer (layer 7) for 2004 improved from the original model results, with a mean residual of $-2.56 \mathrm{ft}$, median residual of $-1.50 \mathrm{ft}$, and a RMSE of $5.34 \mathrm{ft}$.

Comparison of simulated water levels from 2000 to 2004 indicate water-level rises, with the exception of the Brunswick aquifer system (layers 3 and 5), where pumpage increases resulted in groundwater-level declines. Simulated water-level changes in the Upper Floridan aquifer ranged from -2.5 to $5 \mathrm{ft}$ in coastal Georgia and exceeded $20 \mathrm{ft}$ near the Georgia-Florida State Line because of pumpage reductions following closure of a nearby paper mill during 2002. In the Brunswick/Glynn County area, the simulated water levels for 2000 and 2004 matched the rising water levels in four continuous recording wells. An increase in simulated pumping during 2004 in the Brunswick aquifer system (layers 3 and 5) resulted in a 3.30-ft decline in simulated water levels from 2000 to 2004 near well 34H437, although observed water levels indicated a rise of $3.04 \mathrm{ft}$.

Simulated potentiometric profiles for 2000 and 2004 were used to evaluate the potentiometric gradients in the upper water-bearing zone of the Upper Floridan aquifer (layer 7) near the chloride plume and the cone of depression caused by production wells in the area. In the Brunswick area, groundwater-flow directions were consistent for both years, with flow paths oriented from south to north and southeast to northwest close to the cone of depression. For 2000, four potentiometric profiles were constructed and simulated and observed water levels were compared in 13 wells, yielding a mean residual of $-0.19 \mathrm{ft}$. The simulated potentiometric gradients of the four profiles, which ranged from 3.6 to 5.2 feet per mile (ft $/ \mathrm{mi}$ ), were comparable to the observed values, which ranged from 4.1 to $5.6 \mathrm{ft} / \mathrm{mi}$. For 2004, five potentiometric profiles were constructed and simulated and observed water levels were compared in 18 wells, yielding a mean residual of $-0.18 \mathrm{ft}$. The simulated potentiometric gradients of the five profiles, which ranged from 3.6 to $11.1 \mathrm{ft} / \mathrm{mi}$, were comparable to the observed values, which ranged from 3.8 to $10.2 \mathrm{ft} / \mathrm{mi}$. Simulated potentiometric gradients were higher for 2004 than 2000 , because four of the 2004 profiles included a well located within the cone of depression near downtown Brunswick.

Composite-scaled sensitivities of key hydrologic parameters indicate that the revised model is most sensitive to changes in pumping rates, and at least an order of magnitude more so than to changes in the horizontal hydraulic conductivity of zones in the Upper Floridan aquifer and the conductance of the general-head boundary. The revised groundwaterflow model is least sensitive to changes in the horizontal hydraulic conductivity of the confining units and the vertical hydraulic conductivity of the aquifers.

The revised model is subject to the limitations documented in the original model associated with the relatively sparse data available to assign parameters to the groundwaterflow system and inaccuracies with numerically representing complex aquifer geometry and curved potentiometric surfaces with an orthogonal-grid-based approximation using finitedifferent techniques embodied in MODFLOW-2000. The values assigned to specified-head boundaries in the Floridan aquifer system (layers 7-11) have the greatest effect on water inflows to pumping centers in the Brunswick/Glynn County area and are based on sparse data for 2000 and 2004. The flow budgets for 2000 and 2004 indicate the specified-head boundaries in the Floridan aquifer system (layers 7-11) provide nearly 70 percent of the model inflows and about 50 percent of the model outflows. A major limitation of the revised model's ability to assess the effects of pumpage on the aquifer system and chloride migration hinges on the model's dependence on flow from specified-head boundaries to supply most of the water to the pumping centers. These boundary conditions regulate changes to hydraulic gradients in response to pumpage changes by supplying limitless quantities of water to satisfy pumping demand. 


\section{Selected References}

Applied Coastal Research Laboratory, Georgia Southern University, 2002, Gulf Trough and Satilla Line data analysis: Georgia Geologic Survey Project Report 48, 15 p.

Brooks, Rebekah, Clarke, J.S., and Faye R.E., 1985, Hydrogeology of the Gordon aquifer system of eastcentral Georgia: Georgia Geologic Survey Information Circular 75, 41 p. (Also available at http://ga.water.usgs. gov/publications/ggs/ic-75/.)

Charm, W.B., Nesteroff, W.D., and Valdes, Sylvia, 1969, Detailed stratigraphic description of the JOIDES cores on the continental margin off Florida: U.S. Geological Survey Professional Paper 581-D, 13 p. (Also available at http://pubs.er.usgs.gov/publication/pp581D.)

Cherry, G.S., 2007, U.S. Geological Survey Georgia Water Science Center and City of Brunswick-Glynn County Cooperative Water Program-Summary of activities, July 2005 through June 2006: U.S. Geological Survey Open-File Report 2006-1368, 64 p. (Also available at http:/pubs.usgs.gov/of/2006/1368/.)

Cherry, G.S., and Clarke, J.S., 2008, Groundwater conditions and studies in the Brunswick-Glynn County area, Georgia, 2007: U.S. Geological Survey OpenFile Report 2008-1297, 42 p. (Also available at http://pubs.usgs.gov/of/2008/1297/.)

Cherry, G.S., Peck M.F., Painter, J.A., and Stayton, W.L., 2010, Groundwater conditions and studies in the Brunswick-Glynn County area, Georgia, 2008: U.S. Geological Survey Open-File Report 2009-1275, 54 p. (Also available at http://pubs.usgs.gov/of/2009/1275/.)

Cherry, G.S., Peck, M.F., Painter, J.A., and Stayton, W.L., 2011, Groundwater conditions and studies in the BrunswickGlynn County area, Georgia, 2009: U.S. Geological Scientific Investigations Report 2011-5087, 58 p. (Also available at http://pubs.usgs.gov/sir/2011/5087/.)

Clarke, J.S., 2003, The surficial and Brunswick aquifer systems - Alternative groundwater resources for coastal Georgia, in Hatcher, K.J., ed., Proceedings of the 2003 Georgia Water Resources Conference, April 23-24, 2003: Athens, Ga., University of Georgia, Institute of Ecology, CD-ROM. (Also available at http://ga.water.usgs.gov/ publications/other/gwrc2003/pdf/Clarke-GWRC2003.pdf.)

Clarke, J.S., Cherry, G.S., and Gonthier, G.J., 2011, Hydrogeology and water quality of the Floridan aquifer system and effects of Lower Floridan aquifer pumping on the Upper Floridan aquifer at Fort Stewart, Georgia: U.S. Geological Survey Scientific Investigations Report 2011-5065, 59 p. (Also available at http://pubs.usgs.gov/ $\operatorname{sir} / 2011 / 5065 /$.
Clarke, J.S., Hacke, C.M., and Peck, M.F., 1990, Geology and groundwater resources of the coastal area of Georgia: Georgia Geologic Survey Bulletin 113, 106 p. (Also available at http:/ga.water.usgs.gov/publications/ggs/bull-113/.)

Clarke, J.S., and Krause, R.E., 2000, Design, revision, and application of ground-water flow models for simulation of selected water-management scenarios in the coastal area of Georgia and adjacent parts of South Carolina and Florida: U.S. Geological Survey Water-Resources Investigations Report 00-4084, 93 p. (Also available at http://pubs.usgs. gov/wri/wri00-4084.)

Clarke, J.S., Leeth, D.C., Taylor-Harris, DáVette, Painter, J.A., and Labowski, J.L., 2004, Summary of hydraulic properties of the Floridan aquifer system in coastal Georgia and adjacent parts of South Carolina and Florida: U.S. Geological Survey Scientific Investigations Report 2004-5264, 50 p. (Also available at http://pubs.usgs.gov/sir/2004/5264/.)

Clarke, J.S., and West, C.T., 1998, Simulation of ground-water flow and stream-aquifer relations in the vicinity of the Savannah River Site, Georgia and South Carolina, predevelopment through 1992: U.S. Geological Survey WaterResources Investigations Report 98-4062, 134 p. (Also available at http://pubs.usgs.gov/wri/wri98-4062/.)

Clarke, J.S., Williams, L.J., and Cherry, G.S., 2010, Hydrogeology and water quality of the Floridan aquifer system and effect of Lower Floridan aquifer pumping on the Upper Floridan aquifer at Hunter Army Airfield, Chatham County, Georgia: U.S. Geological Survey Scientific Investigations Report 2010-5080, 56 p. (Also available at http://pubs.usgs.gov/sir/2010/5080/.)

de Marsily, Ghislain, 1986, Quantitative hydrogeology: Orlando, Fla., Academic Press, Inc., 440 p.

Falls, W.F., Baum, J.S., Harrelson, L.G., Brown, L.H., and Jerden, J.L., Jr., 1997, Geology and hydrogeology of Cretaceous and Tertiary strata, and confinement in the vicinity of the U.S. Department of Energy Savannah River Site, South Carolina: U.S. Geological Survey WaterResources Investigations Report 97-4245, 125 p. (Also available at http://pubs.er.usgs.gov/publication/wri974245.)

Falls, W.F., Harrelson, L.G., Conlon, K.J., and Petkewich, M.D., 2001, Hydrogeology and water quality of the Lower Floridan aquifer, coastal Georgia, 1999-2000, in Hatcher, K.J., ed., Proceedings of the 2001 Georgia Water Resources Conference, March 26-27, 2001: Athens, Ga., University of Georgia, Institute of Ecology, p. 652-655.

Falls, W.F., Harrelson, L.G., Conlon, K.J., and Petkewich, M.D., 2005, Hydrogeology, water quality, and water-supply potential of the Lower Floridan aquifer, coastal Georgia 19992002: U.S. Geological Survey Scientific Investigations Report 2005-5124, 98 p. (Also available at http://pubs.usgs. gov/sir/2005/5124/.) 
Fanning, J.L., 2003, Water use in Georgia by county for 2000 and water-use trends for 1980-2000: Georgia Geologic Survey Information Circular 106, 180 p. (Also available at http://ga.water.usgs.gov/publications/other/ggs-ic106/.)

Faye, R.E., and Mayer, G.C., 1990, Ground-water flow and stream-aquifer relations in the northern Coastal Plain of Georgia and adjacent parts of Alabama and South Carolina: U.S. Geological Water-Resources Investigations Report 88-4143, 83 p. (Also available at http://pubs.er.usgs. gov/publication/wri884143.)

Foyle, A.M., Henry, V.J., and Alexander, C.R., 2001, The Miocene aquitard and the Floridan aquifer of the Georgia/ South Carolina coast - Geophysical mapping of potential seawater intrusion sites: Georgia Geologic Survey Bulletin 132, 61 p.

Georgia Environmental Protection Division, 1997, Secondary Maximum Contaminant Levels for drinking waterEnvironmental Rule 391-3-5-19, revised October 1997: Official Code of Georgia Annotated Statutes, Statute 12-5-170 (Georgia Safe Drinking Water Act), variously paginated.

Georgia Environmental Protection Division, 2005, Coastal Georgia Water \& Wastewater Permitting Plan for Managing Salt Water Intrusion: Georgia Environmental Protection Division draft report, 54 p., accessed July 27, 2010, at http://www1.gadnr.org/cws/Documents/saltwater_management_plan.pdf.

Gregg, D.O., and Zimmerman, E.A., 1974, Geologic and hydrologic control of chloride contamination in aquifers at Brunswick, Glynn County, Georgia: U.S. Geological Water-Supply Paper 2029-D, 44 p. (Also available at http://pubs.er.usgs.gov/publication/wsp2029D.)

Harbaugh, A.W., 1990, A computer program for calculating subregional water budgets using results from the U.S. Geological Survey modular three-dimensional finitedifference groundwater flow model: U.S. Geological Survey Open-File Report 90-392, 46 p. (Also available at http://pubs.er.usgs.gov/publication/ofr90392.)

Harbaugh, A.W., Banta, E.R., Hill, M.C., and McDonald, M.G., 2000, MODFLOW-2000, The U.S. Geological Survey modular ground-water model-User guide to modularization concepts and the ground-water flow process: U.S. Geological Survey Open-File Report 00-92, 121 p. (Also available at http://pubs.er.usgs.gov/publication/ofr200092.)

Hathaway, J.C., Schlee, J.S., Poag, W.C., Valentine, P.C., Weed, E.G.A., Bothner, M.H., Kohout, F.A., Manheim, F.T., Schoen, Robert, Miller, R.E., and Schultz, D.M., 1981, Summary of the 1976 Atlantic margin coring project of the U.S. Geological Survey: U.S. Geological Survey Open-File Report 81-0239, 217 p.
Herrick, S.M., and Vorhis, R.C., 1963, Subsurface geology of the Georgia Coastal Plain: Georgia Department of Natural Resources, Division of Mines, Mining, and Geology Information Circular 25, $80 \mathrm{p}$.

Hill, M.C., 1998, Methods and guidelines for effective model calibration: U.S. Geological Survey Water-Resources Investigations Report 98-4005, 90 p.

Hill, M.C., Banta, E.R., Harbaugh, A.W., and Anderman, E.R., 2000, MODFLOW-2000, the U.S. Geological Survey modular ground-water model-User guide to the observation, sensitivity, and parameter-estimation processes and three post-processing programs: U.S. Geological Survey Open-File Report 00-184, 209 p. (Also available at http://pubs.er.usgs.gov/publication/ofr00184.)

Johnston, R.H., Healy, H.G., and Hayes, L.R., 1981, Potentiometric surface of the Tertiary limestone aquifer system, southeastern United States, May 1980: U.S. Geological Survey Open-File Report 81-486, 1 sheet.

Jones, L.E., and Maslia, M.L., 1994, Selected ground-water data, and results of aquifer tests for the Upper Floridan aquifer, Brunswick, Glynn County, Georgia, area: U.S. Geological Survey Open-File Report 94-520, 107 p. (Also available at http://pubs.er.usgs.gov/publication/ofr94520.)

Jones, L.E., Prowell, D.C., and Maslia, M.L., 2002, Hydrogeology and water quality (1978) of the Floridan aquifer system at U.S. Geological Survey Test Well 26, on Colonels Island, near Brunswick, Georgia: U.S. Geological Survey Water-Resources Investigations Report 02-4020, 44 p. (Also available at http://pubs.usgs.gov/wri/2002/ wri02-4020/.)

Kellam, M.F., and Gorday, L.L., 1990, Hydrogeology of the Gulf Trough-Apalachicola Embayment area, Georgia: Georgia Geologic Survey Bulletin 94, 73 p.

Kottek, Markus, Grieser, Jürgen, Beck, Christoph, Rudolf, Bruno, and Rubel, Franz, 2006: World map of the Köppen-Geiger climate classification updated: Meteorologische Zeitschrift, v. 15, no. 3, p. 259-263, accessed September 26, 2013, at http://koeppen-geiger.vu-wien.ac.at/usa.htm.

Krause, R.E., Matthews, S.E., and Gill, H.E., 1984, Evaluation of the groundwater resources of coastal GeorgiaPreliminary report on the data available as of July, 1983: Georgia Geologic Survey Information Circular 62, 55 p.

Krause, R.E., and Randolph, R.B., 1989, Hydrology of the Floridan aquifer system in southeast Georgia and adjacent parts of Florida and South Carolina: U.S. Geological Survey Professional Paper 1403-D, 65 p., 18 pl. 
Kuniansky, E.L., Gomez-Gomez, Fernando, and Torres-Gonzalez, Sigfredo, 2003, Effects of aquifer development and changes in irrigation practices on groundwater availability in the Santa Isabel area, Puerto Rico: U.S. Geological Survey Water-Resources Investigations Report 03-4303, 56 p. (Also available at http://pubs.er.usgs. gov/publication/wri20034303.)

Leeth, D.C., 1999, Hydrogeology of the surficial aquifer in the vicinity of a former landfill, Naval Submarine Base Kings Bay, Camden County, Georgia: U.S. Geological Survey Water-Resources Investigations Report 98-4246, 28 p. (Also available at http://pubs.usgs.gov/wri/wri98-4246/.)

Leeth, D.C., Clarke, J.S., Craigg S.D., and Wipperfurth, C.J., 2003, Ground-water conditions and studies in Georgia, 2001: U.S. Geological Survey Water-Resources Investigations Report 03-4032, 96 p. (Also available at http://pubs.usgs.gov/wri/wri034032/.)

Leeth, D.C., Peck, M.F., and Painter, J.A., 2007, Groundwater conditions and studies in Georgia, 2004-2005: U.S. Geological Survey Scientific Investigations Report 2007-5017, 299 p. (Also available at http://pubs.usgs.gov/sir/2007/5017/.)

Marella, R.L., 2004, Water withdrawals, use, discharge, and trends in Florida, 2000: U.S. Geological Survey Scientific Investigations Report 2004-5151, 136 p. (Also available at http://pubs.er.usgs.gov/publication/sir20045151.)

Maslia, M.L., 1987, Regional and local tensor components of a fractured carbonate aquifer, in Farmer, I.W., Daemen, J.J.K., Desai, C.S., Glass, C.E., and Neuman, S.P., eds., Proceedings of the 28th U.S. Symposium on Rock Mechanics, University of Arizona, June 29-July 1, 1987, p. $441-452$.

Maslia, M.L., and Prowell, D.C., 1990, Effects of faults on fluid flow and chloride contamination in a carbonate aquifer system: Journal of Hydrology, v. 115, nos. 1-4, p. 1-49. (Also available at http://pubs.er.usgs.gov/ publication/70016336.)

Miller, J.A., 1986, Hydrogeologic framework of the Floridan aquifer system in Florida and in parts of Georgia, Alabama, and South Carolina: U.S. Geological Survey Professional Paper 1403-B, 91 p., 33 pl. (Also available at http://pubs. er.usgs.gov/publication/pp1403B.)

National Oceanic and Atmospheric Administration, 2002, Monthly station normals of temperature, precipitation, and heating and cooling degree days 1971-2000: Asheville, N.C., no. 81,28 p.
National Oceanic and Atmospheric Administration, 2014, Jacksonville 1981-2010 climate normals: National Weather Service Weather Forecast Office Web site, accessed April 23, 2014, at http://www.srh.noaa.gov/news/display_ cmsstory.php? wfo $=$ jax \&storyid $=71081 \&$ source $=0$.

Paull, C.K., and Dillon, W.P., 1980, Structure, stratigraphy, and geologic history of Florida-Hatteras Shelf and inner Blake Plateau: American Association of Petroleum Geologists Bulletin, v. 64, p. 339-358.

Payne, D.F., Abu Rumman, Malek, and Clarke, J.S., 2005, Simulation of groundwater flow in coastal Georgia and adjacent parts of South Carolina and FloridaPredevelopment, 1980, and 2000: U.S. Geological Survey Scientific Investigations Report 2005-5089, 91 p. (Also available at http://pubs.usgs.gov/sir/2005/5089/.)

Peck, M.F., Clarke, J.S., Ransom, Camille, III, and Richards, C.J., 1999, Potentiometric surface of the Upper Floridan aquifer in Georgia and adjacent parts of Alabama, Florida, and South Carolina, May 1998, and water-level trends in Georgia, 1990-98: Georgia Geologic Survey Hydrologic Atlas 22, 1 sheet, scale 1:100,000. (Also available at http://ga.water.usgs.gov/publications/ggs/hydatlas-22/.)

Peck, M.F., and McFadden, K.W., 2004, Potentiometric surface of the Upper Floridan aquifer in the Coastal area of Georgia, September 2000: U.S. Geological Survey Open-File Report 2004-1030, 1 sheet. (Also available at http://pubs.usgs.gov/of/2004/1030/.)

Peck, M.F., McFadden, K.W., and Leeth, D.C., 2004, Effects of decreased ground-water withdrawal on groundwater levels and chloride concentration in Camden County, Georgia, and ground-water levels in Nassau County, Florida, from September 2001 to May 2003: U.S. Geological Survey Scientific Investigations Report 2004-5295, 36 p. (Also available at http://pubs.usgs.gov/ sir/2004/5295/.)

Peck, M.F., and Payne, D.F., 2003, Development of an estimated water-table map for coastal Georgia and adjacent parts of Florida and South Carolina, in Hatcher, K.J., ed., Proceedings of the 2003 Georgia Water Resources Conference, April 23-24, 2003: Athens, Ga., University of Georgia, Institute of Ecology, CD-ROM. (Also available at http:/ga.water.usgs.gov/publications/other/gwrc2003/pdf/ Peck_Payne-GWRC2003.pdf.)

Priest, Sherlyn, 2004, Evaluation of ground-water contribution to streamflow in coastal Georgia and adjacent parts of Florida and South Carolina: U.S. Geological Survey Scientific Investigations Report 2004-5265, 40 p. (Also available at http://pubs.usgs.gov/sir/2004/5265/.) 
Randolph, R.B., and Krause, R.E., 1990, Analysis of the effects of hypothetical changes in ground-water withdrawal from the Floridan aquifer system in the area of Glynn County, Georgia: U.S. Geological Survey Water-Resources Investigations Report 90-4027, 32 p. (Also available at http://pubs.er.usgs.gov/publication/wri904027.)

Randolph, R.B., Pernik, Maribeth, and Garza, Reggina, 1991, Water-supply potential of the Floridan aquifer system in the coastal area of Georgia-A digital model approach: Georgia Geologic Survey Bulletin 116, 30 p.

Ransom, Camille, III, and White, J.I., 1999, Potentiometric surface of the Floridan aquifer system in southern South Carolina: South Carolina Department of Health and Environmental Control, Bureau of Water Publication no. $02 \mathrm{~B}-99,1$ sheet.

Remson, I, Appel, C.A., and Molz, F.J., 1971, Numerical methods in subsurface hydrology: New York, John Wiley and Sons, Inc., 389 p.

Scholle, P.A., 1979, Geological studies of the COST GE-1 well, United States south Atlantic outer continental shelf area: U.S. Geological Survey Circular 800, 114 p.

Sepúlveda, Nicasio, 2002, Simulation of ground-water flow in the intermediate and Floridan aquifer systems in peninsular Florida: U.S. Geological Survey Water-Resources Investigations Report 02-4009, 130 p.

Siple, G.E., 1960, Geology and ground-water conditions in the Beaufort area, South Carolina: U.S. Geological Survey Open-File Report, 124 p.

Southeast Regional Climate Center, 2009, Historical climate summaries: Southeast Regional Climate Center Web Site, accessed on May 19, 2009, at http://www.sercc.com/ climateinfo/historical/historical.

Steele, W.M., and McDowell, R.J., 1998, Permeable thickness of the Miocene upper and lower Brunswick aquifers, coastal area, Georgia: Georgia Geologic Survey Information Circular 103, $34 \mathrm{p}$.

Taylor, D.A., Painter, J.A., and Payne, D.F., 2003, Development of a water-use database for use in coastal region ground-water models, Georgia, South Carolina, and Florida, 1980-2000, in Hatcher, K.J., ed., Proceedings of the 2003 Georgia Water Resources Conference, April 23-24, 2003: Athens, Ga., The University of Georgia, Institute of Ecology, CD-ROM. (Also available at http:/ga.water.usgs.gov/publications/other/gwrc2003/pdf/ Taylor-GWRC2003.pdf.)
U.S. Census Bureau, 2010, State \& county quickfacts-Glynn County, Georgia: U.S Census Bureau Web site, accessed on April 23, 2014, at http://quickfacts.census.gov/qfd/ states/13/13127.html.

U.S. Environmental Protection Agency, 2000 (revised), Maximum Contaminant Levels (Part 143, National Secondary Drinking-Water Regulations): U.S. Code of Federal Regulations, Title 40, parts 100-149.

Wait, R.L., 1962, Interim report on test drilling and water sampling in the Brunswick area, Glynn County, Georgia: Georgia Geological Survey Information Circular 23, 46 p.

Wait, R.L., 1965, Geology and occurrence of fresh and brackish water in Glynn County, Georgia: U.S. Geological Survey Water-Supply Paper 1613-E, 94 p. (Also available at http://pubs.er.usgs.gov/publication/wsp1613E.)

Wait, R.L., and Davis, M.E., 1986, Configuration and hydrology of the pre-Cretaceous rocks underlying the southeastern Coastal Plain aquifer system: U.S. Geological Survey Water-Resources Investigations Report 86-4010, 1 sheet, scale 1:2,000,000. (Also available at http://pubs. er.usgs.gov/publication/wri864010.)

Wait, R.L., and Gregg, D.O., 1973, Hydrology and chloride contamination of the principal artesian aquifer in Glynn County: Georgia Department of Natural Resources Hydrologic Report, 93 p.

Warner, Debbie, and Aulenbach, B.T., 1999, Hydraulic characteristics of the Upper Floridan aquifer in the Savannah and St. Marys areas of coastal Georgia: Georgia Geologic Survey Information Circular 105, 23 p. (Also available at http://ga.water.usgs.gov/publications/other/ggs-ic105/.)

Warren, M.A., 1944, Artesian water in southeastern Georgia with special reference to the coastal area: Georgia Geological Survey Bulletin 49, 140 p.

Weems, R.E., and Edwards, L.E., 2001, Geology of Oligocene, Miocene, and younger deposits in the coastal area of Georgia: Georgia Geologic Survey Bulletin 131, 124 p. (Also available at http:/ga.water.usgs.gov/publications/ggs/ bull-131/.)

Williamson, A.K., Grubb, H.F., and Weiss, J.S., 1990, Groundwater flow in the Gulf Coast aquifer systems, south central United States-A preliminary analysis: U.S. Geological Survey Water-Resources Investigations Report 89-4071, 124 p. (Also available at http://pubs.er.usgs.gov/publication/ wri894071.) 


\section{Appendix 1}

Table 1-1. Simulated and observed groundwater levels, 2000 and 2004.

[Simulated and observed groundwater levels are above or below (-) NAVD 88; observed values for 2000 are during September; observed values for 2004 are during June; see fig. 2-1 for well locations; - , no data]

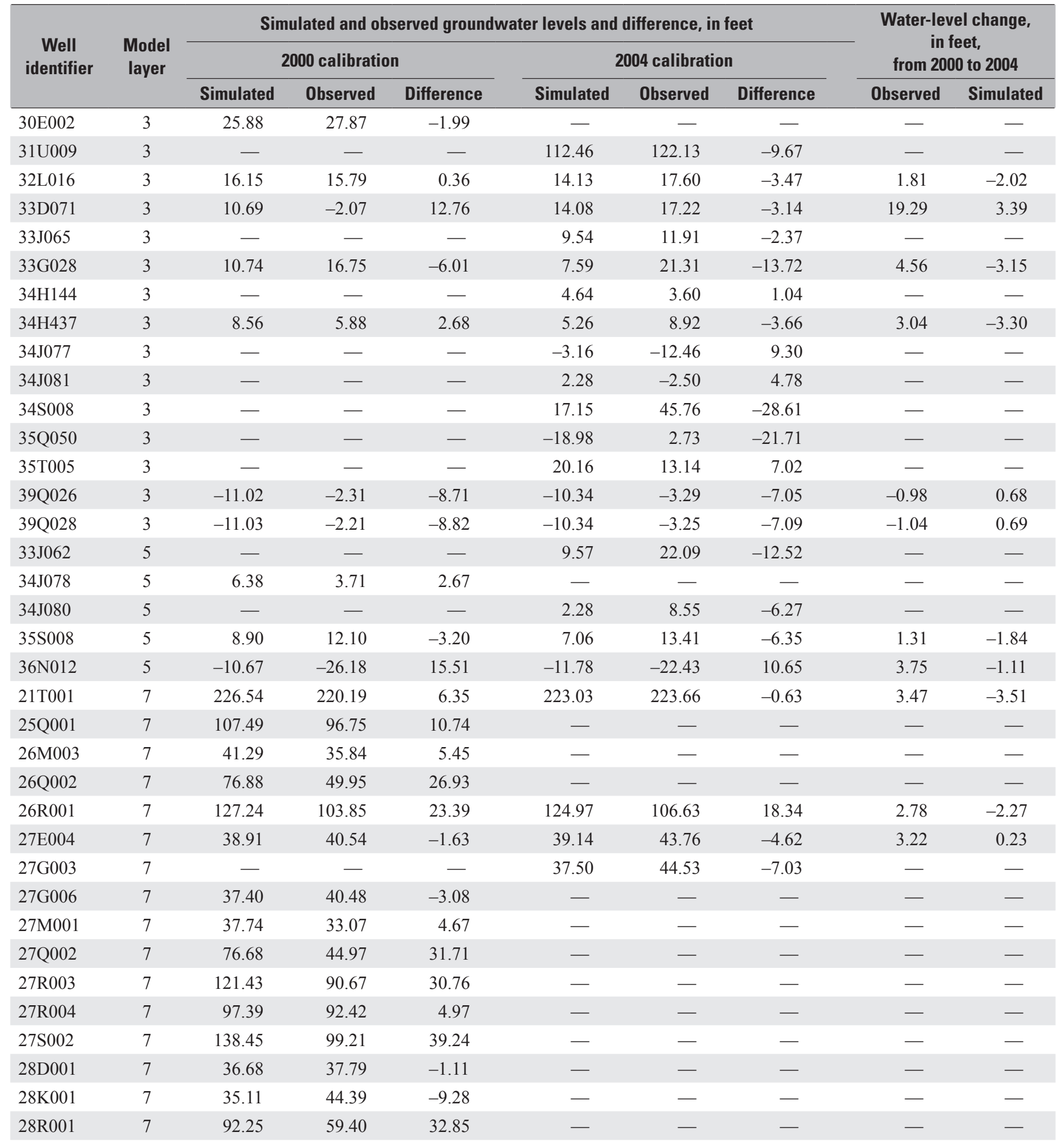


Table 1-1. Simulated and observed groundwater levels, 2000 and 2004._- Continued

[Simulated and observed groundwater levels are above or below (-) NAVD 88; observed values for 2000 are during September; observed values for 2004 are during June; see fig. 2-1 for well locations; - , no data]

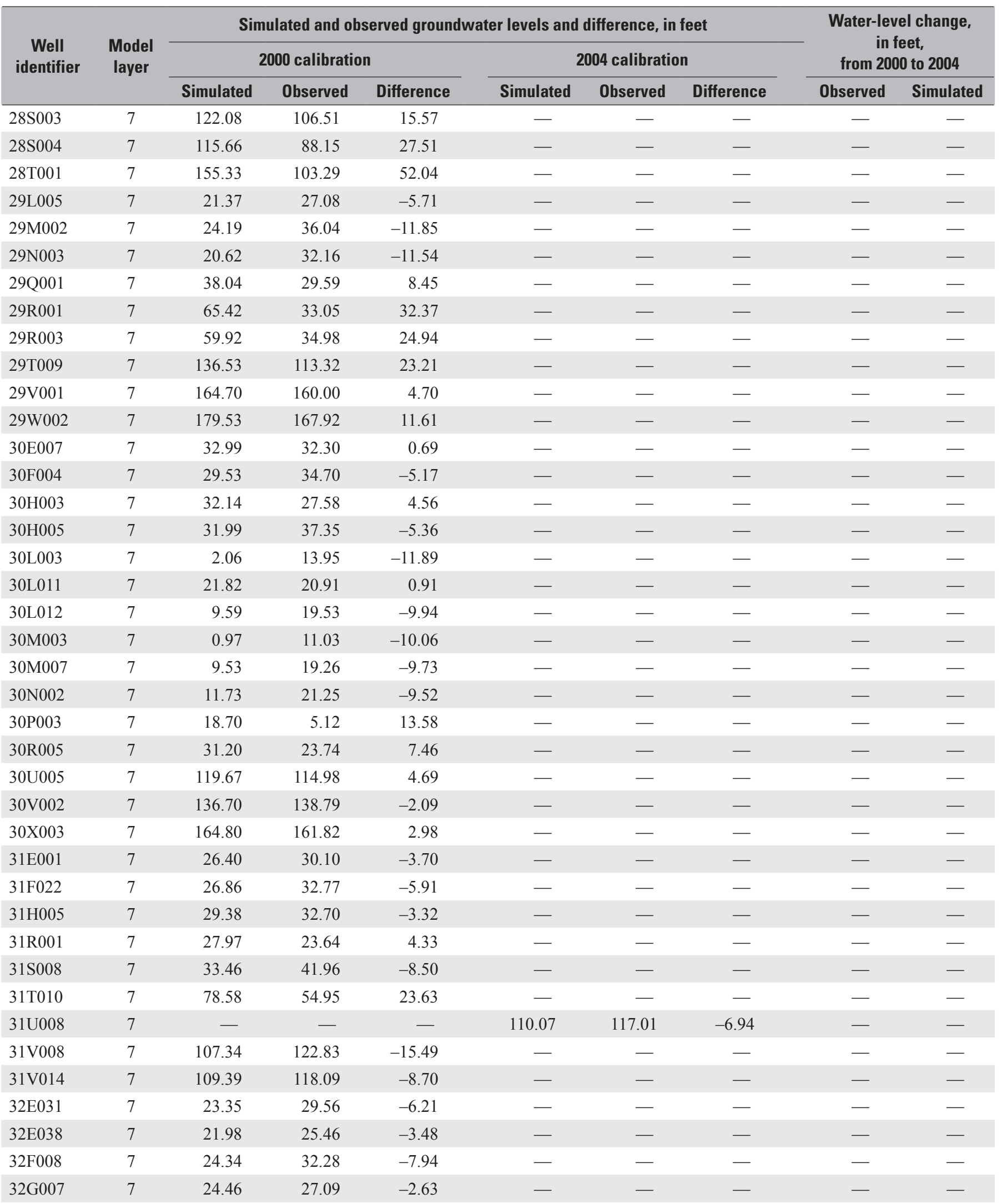


Table 1-1. Simulated and observed groundwater levels, 2000 and 2004.-Continued

[Simulated and observed groundwater levels are above or below (-) NAVD 88; observed values for 2000 are during September; observed values for 2004 are during June; see fig. 2-1 for well locations; - , no data]

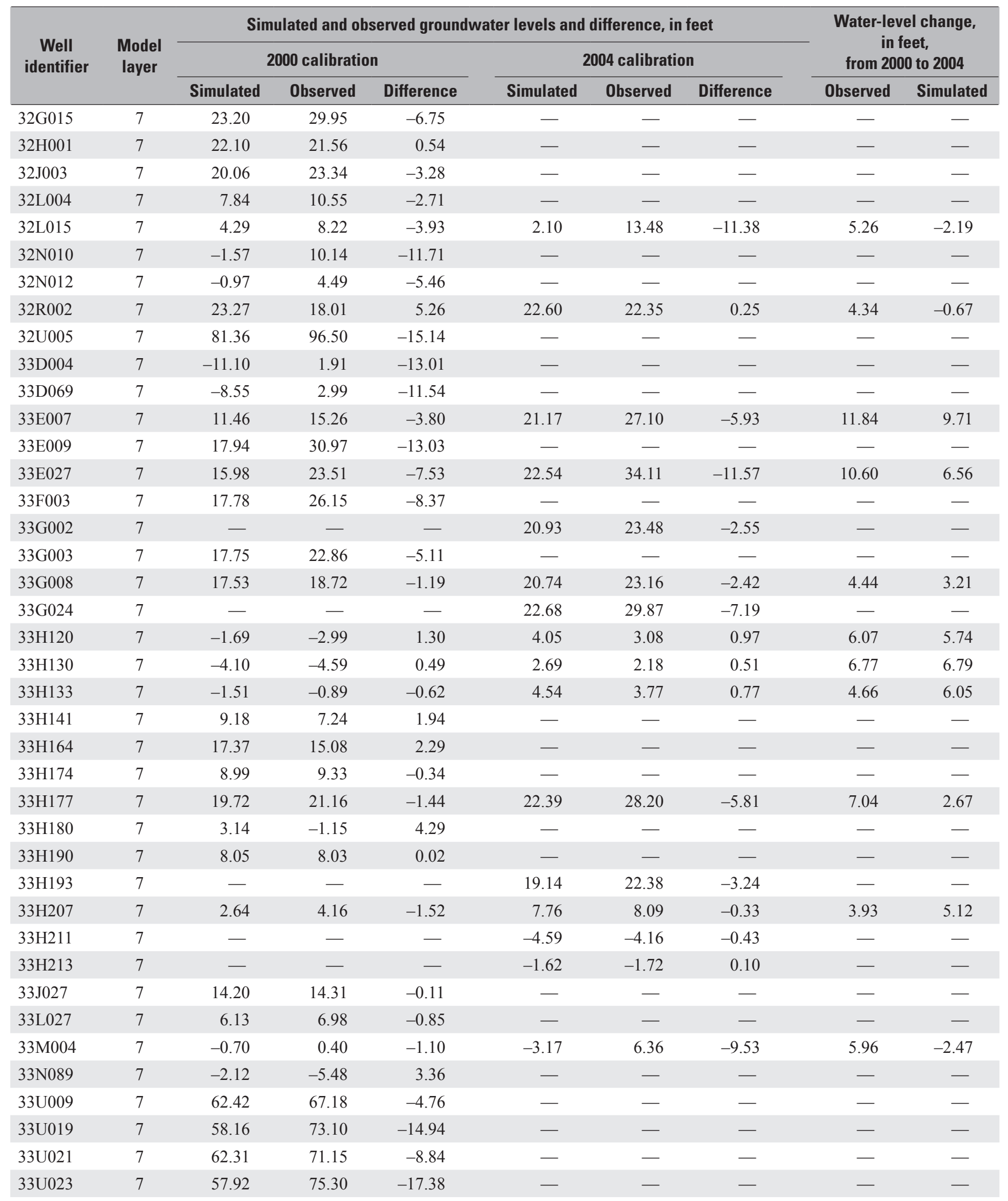


Table 1-1. Simulated and observed groundwater levels, 2000 and 2004.-Continued

[Simulated and observed groundwater levels are above or below (-) NAVD 88; observed values for 2000 are during September; observed values for 2004 are during June; see fig. 2-1 for well locations; - , no data]

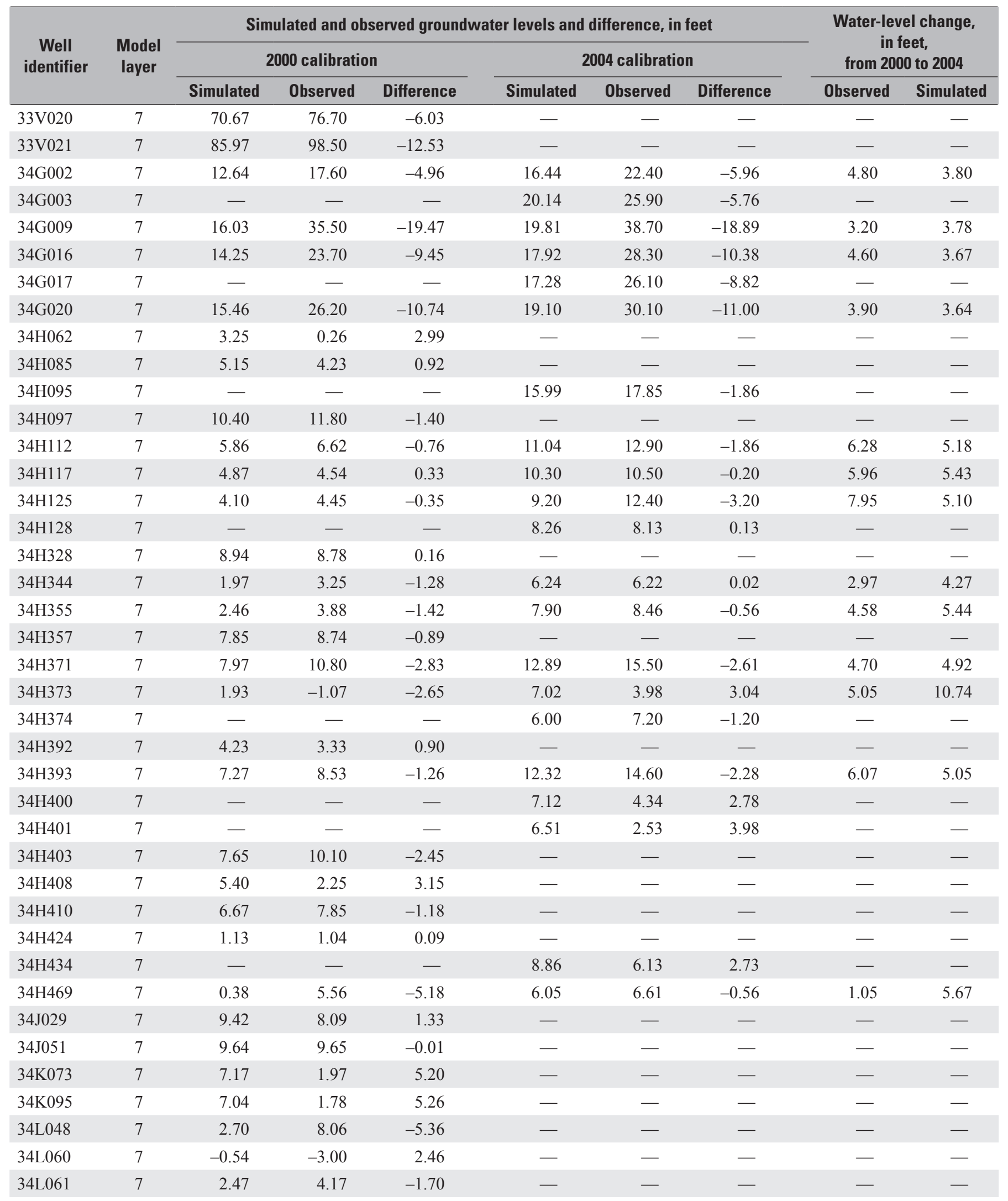


Table 1-1. Simulated and observed groundwater levels, 2000 and 2004.-Continued

[Simulated and observed groundwater levels are above or below (-) NAVD 88; observed values for 2000 are during September; observed values for 2004 are during June; see fig. 2-1 for well locations; - , no data]

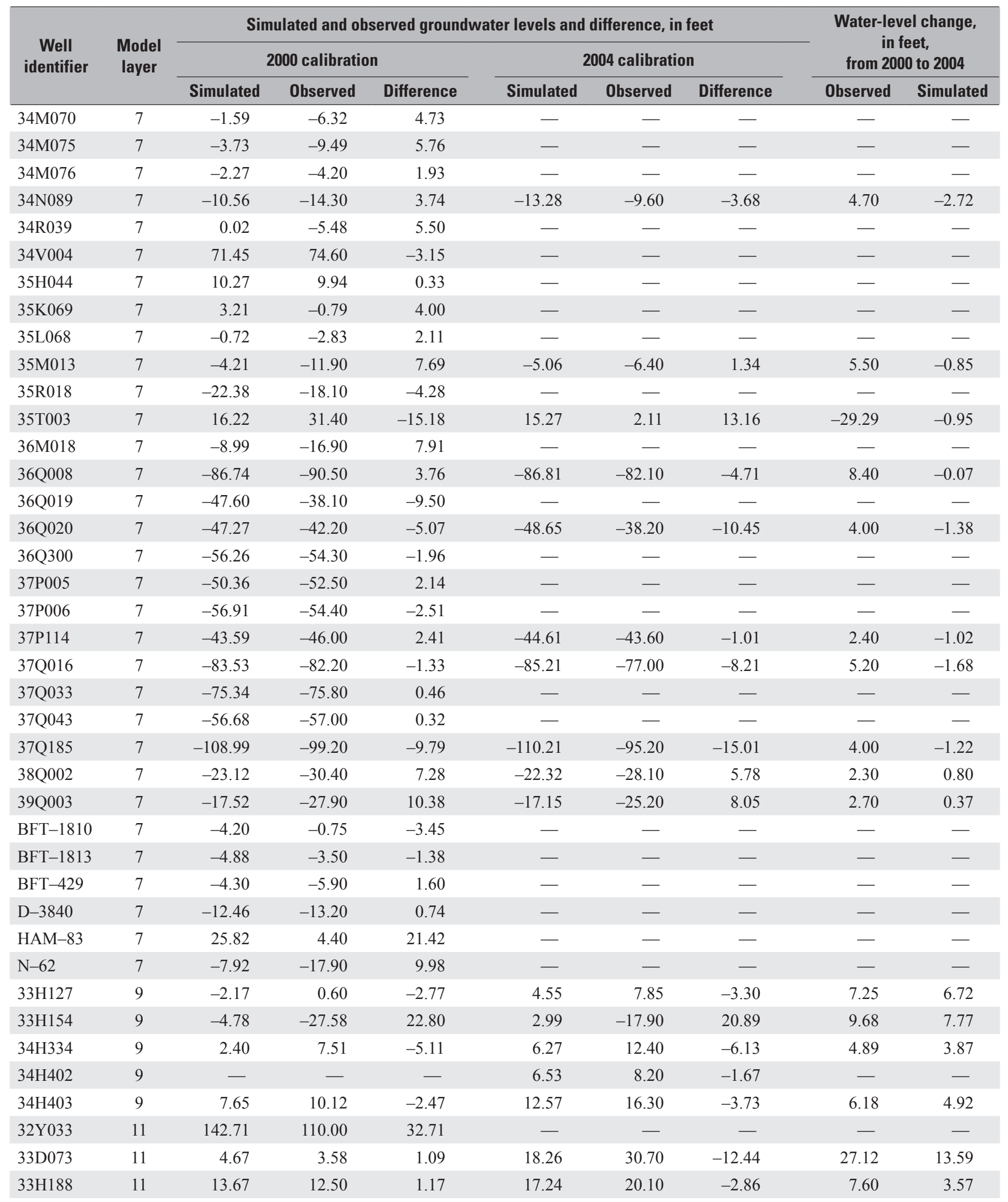


Table 1-1. Simulated and observed groundwater levels, 2000 and 2004.—Continued

[Simulated and observed groundwater levels are above or below (-) NAVD 88; observed values for 2000 are during September; observed values for 2004 are during June; see fig. 2-1 for well locations; - , no data]

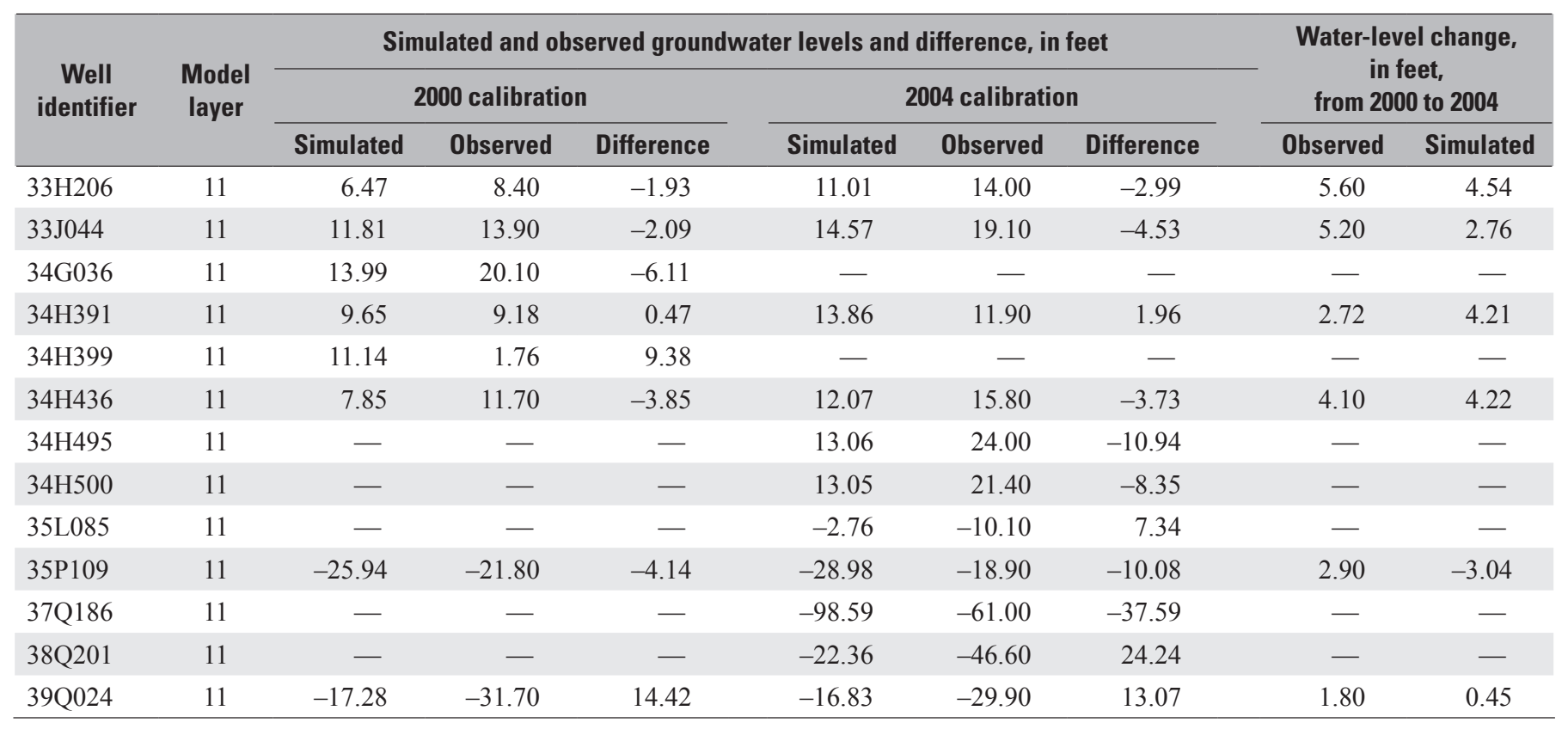




\section{Appendix 2}

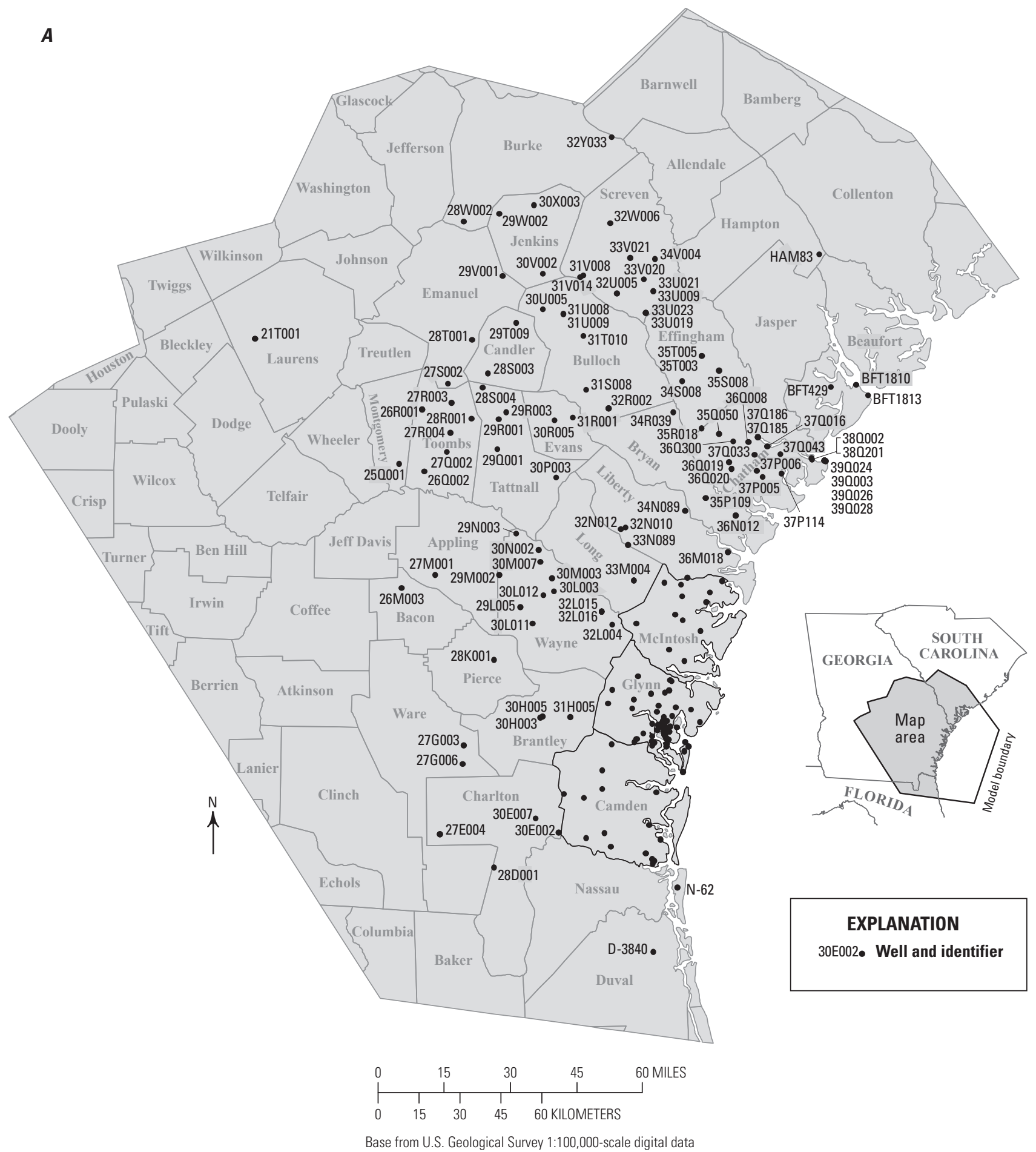

Figure 2-1. Location of wells used for 2000 and 2004 simulations in $A$, study area; B, Mclntosh, Glynn, and Camden Counties (enlarged); and C, Brunswick (enlarged). 


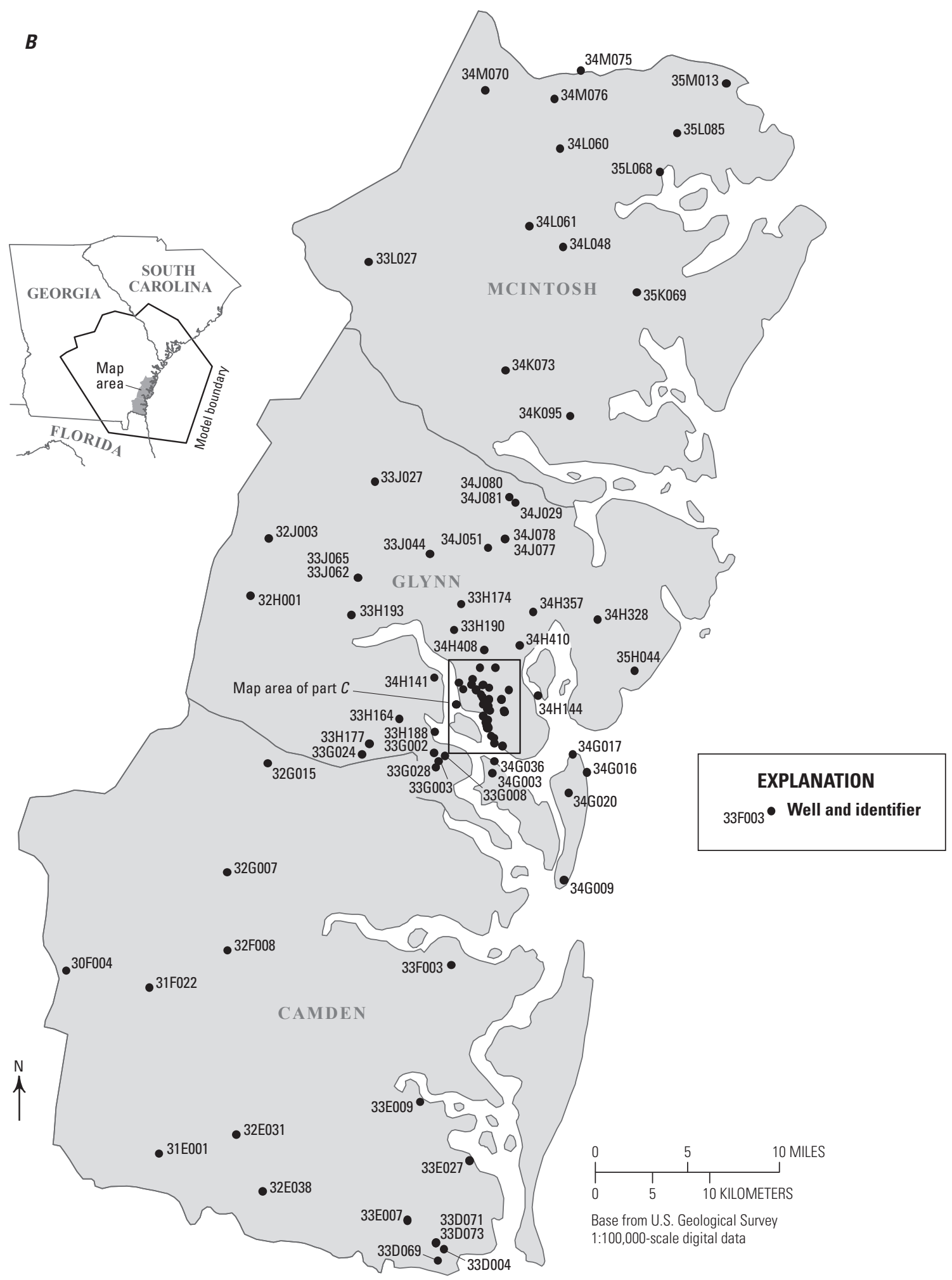

Figure 2-1. Location of wells used for 2000 and 2004 simulations in A, study area; B, Mclntosh, Glynn, and Camden Counties (enlarged); and $C$, Brunswick (enlarged).-Continued 
$c$

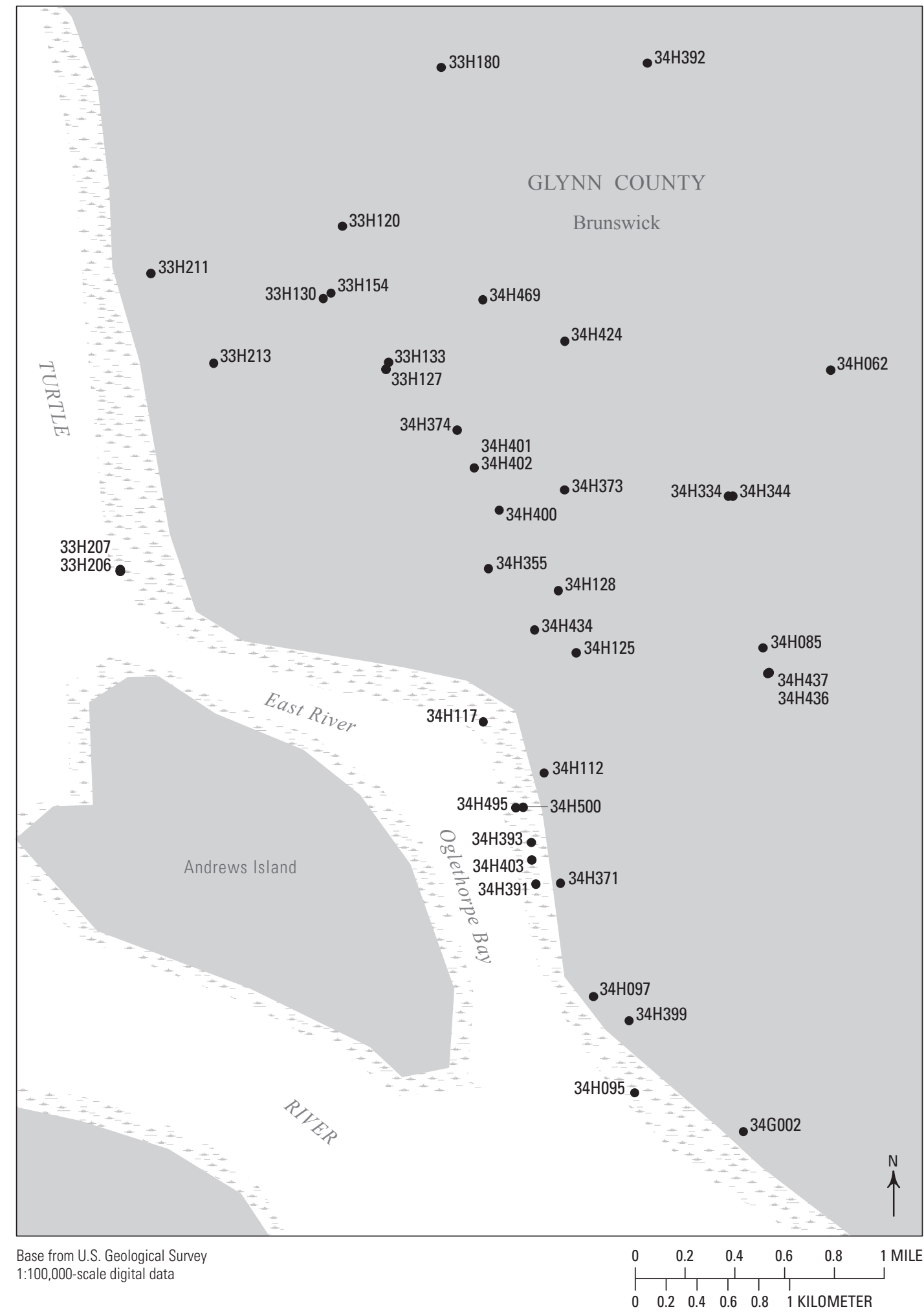

EXPLANATION

34H095 — Well and identifier

Figure 2-1. Location of wells used for 2000 and 2004 simulations in $A$, study area; $B$, Mclntosh, Glynn, and Camden Counties (enlarged); and $C$, Brunswick (enlarged).-Continued 
Manuscript approved April 22, 2015

Prepared by the USGS Science Publishing Network Raleigh Publishing Service Center Edited by Michael Deacon Illustrations and layout by Caryl J. Wipperfurth

For more information concerning this report, contact: Director, South Atlantic Water Science Center North Carolina-South Carolina-Georgia 720 Gracern Road, Suite 129

Columbia, SC 29210

Phone: (803) 750-6100

http://ga.water.usgs.gov/ 
